II. ULUSLARARASI EĞITIM VE BEŞERI BILIMLER ARAŞTIRMALARI KONGRESI

II. INTERNATIONAL CONGRESS OF HUMANITIES AND EDUCATIONAL RESEARCH

IJHER CONGRES

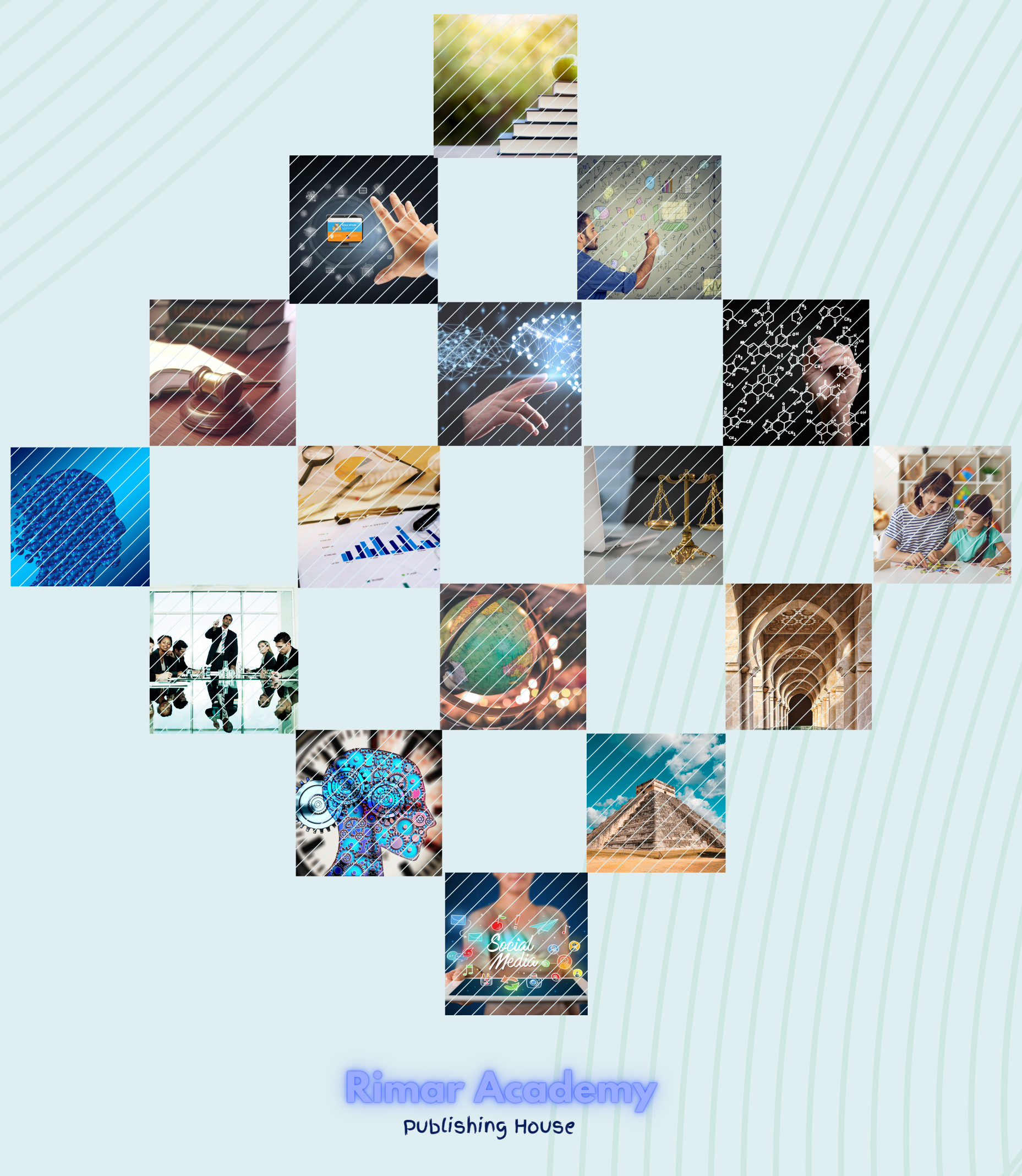


II. International Congress of Humanities and Educational Research

II. Uluslararası Eğitim ve Beşeri Bilimler Araştırmaları Kongresi

المؤتمر العلمي الدولي الثاني للعلوم الإنسانية والتريوية (مؤتمر ايجهار الثاني) 


\section{Editör (المحرر)}

Dr. Ahmet KAYA (ORCID: 0000-0002-7946-1015 -Web of Science Reserarcher ID:AAU-8729-2021)

Hazırlayan (إعداد)

Rimar Academy- أكاديمية ريمار

Yayın Koordinatörü (منسق النشر)

Emel KAPLAN

ISBN:

$978-605-74037-4-2$

kongre Tarihi (تاريخ المؤتمر)

2021 (September) أيلول 09-08-07

Baskı (تاريخ الطباعة)

2021 (December) كانون الأول

Matbaa Sertifikası No (رقم شهادة المطبعة)

47843

Copyright @ $\odot$ Published by Rimar Academy Publishing House 


\section{ÖNSÖZ}

Rimar Academy ile Bitlis Eren Üniversitesi arasında 07-08-09 Eylül 2021 tarihlerinde yapılan “

II. Uluslararası Eğitim ve Beşeri ilimler Araştırmaları Kongeresi”" (International Congress of Humanities and Educational Research) kurum ve kuruluşların kararlı işbirliğinin, çalışmalarının. maddi ve manevi katkılarının sonucunda gerçekleştirilmiştir.

Rimar Academy Türk dünyasının farklı akademik çalışmalarını ortak bir zeminde buluşturmaktadır. Bilim dünyasının değerli insanlarını farklı çevrelere ilişkin; eğitim, edebi, kültürel, sosyal, siyasi, ekonomi ve diğer konulardaki gelişme düzeyinin artırılmasına, ikili ya da bölgesel sorunların çözümüne dair alternatiflerin sunulmasına yönelik bilimsel çalışmaları paylaşmak kongrenin asıl amaçlarından biridir. Rimar Academy Kongre Bildiri Kitabı, bilimsel üretimin geleceğe birikim ve katkı olarak aktarılması hedefiyle hazırlanmışıır.

Bu kongreye yurtdışı ve yurtiçinde olmak üzere toplamda 213 kişi başvurmuştur. 122 kişi bilim kurulu tarafından kabul edildiği; kabul edilen bildirilerin 9'ü Türkiye'den, 113'ü Türkiye dışından 13 ülkeden katılım sağlamıştır. Virüs sebebiyle 56 katılımcı yüz yüze, 66 katılımcı online olarak kongreye katılmıştır. Kongreye 9'1 tam metin kitabi, kalan diğer makaleler IJHER Journal dergisinde yayınlanmaya bilim kurulunca uygun görülmüştür.

Kongremize değerli katkılarından dolayı tüm bilim insanlarına, teşekkür ediyor ve saygılarımı sunuyorum. 
KATILIM SAĞLAYAN ÜLKELR DAĞILIMI

IJHER Congress(2)

40

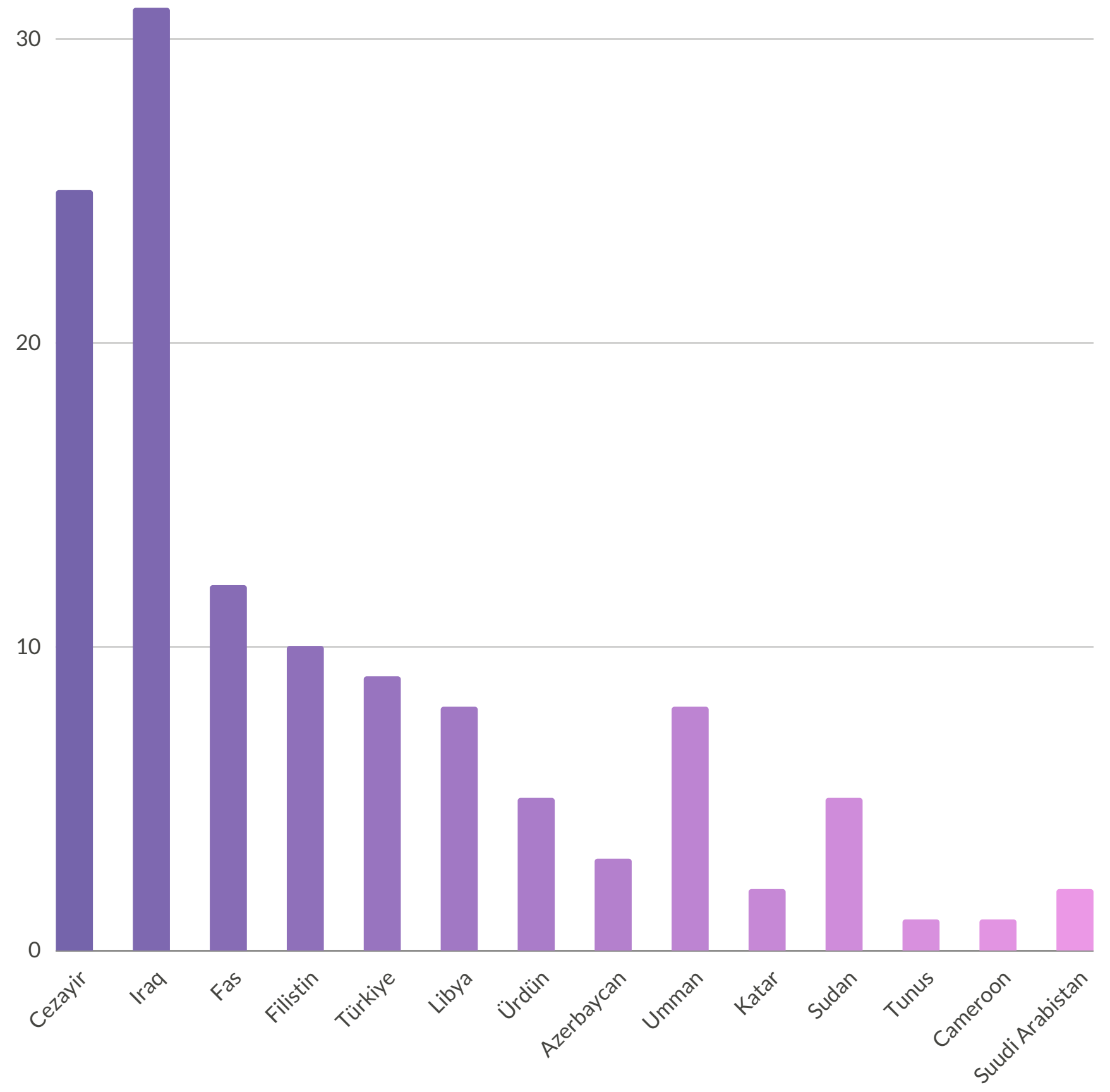




\begin{tabular}{|c|c|c|}
\hline \multicolumn{3}{|c|}{ الـفهرس/çindekiler / Table of contents } \\
\hline $\begin{array}{l}\text { Sawsan Ahmad } \\
\text { NABRESIABBAS }\end{array}$ & $\begin{array}{c}\text { THE MOST USED LEARNING SKILLS IN } \\
\text { LEARNING PROCESS FOR STUDENTS OF AL- } \\
\text { ZAYTONA UNIVERSITY, PALESTINE: ARABIC } \\
\text { COURSE AS A MODEL }\end{array}$ & P. 1-18 \\
\hline $\begin{array}{l}\text { Youssef } \\
\text { GUEROUAOUI }\end{array}$ & $\begin{array}{c}\text { THE REALITY OF EDUCATIONAL SCIENTIFIC } \\
\text { RESEARCH IN REGIONAL CENTERS OF } \\
\text { EDUCATION AND TRAINING PROFESSIONS } \\
\text { AND THE MECHANISMS FOR ITS } \\
\text { DEVELOPMENT }\end{array}$ & P. 19-31 \\
\hline $\begin{array}{l}\text { Omar Falah Awad } \\
\text { AL-JANABI } \\
\text { Ameer Mohammed } \\
\text { Ali Rasool AL- } \\
\text { SADI }\end{array}$ & $\begin{array}{c}\text { EVALUATION OF EDUCATIONAL TELEVISION } \\
\text { LESSONS FOR INTERMEDIATE SCHOOL } \\
\text { BIOLOGY ACCORDING TO PROPOSED } \\
\text { STANDARDS }\end{array}$ & P. $32-47$ \\
\hline Salima GAID & $\begin{array}{l}\text { THE CONTRIBUTIONS OF PHYSICS TO THE } \\
\text { RISE AND DEVELOPMENT OF PHILOSOPHY } \\
\text { AT THE OPENING OF THE MODERN ERA } \\
\end{array}$ & P. 48-61 \\
\hline Hayat MEKKI & $\begin{array}{c}\text { THE HISTORY AND CIVILIZATION OF THE } \\
\text { CITY OF ALGIERS DURING THE PERIOD OF } \\
\text { HUSSEIN DEY }\end{array}$ & P. 62-71 \\
\hline $\begin{array}{l}\text { Mohaj Ghanem } \\
\text { Abdel RAZZAQ } \\
\text { Qahtan Mahboub } \\
\text { FADIL }\end{array}$ & $\begin{array}{l}\text { MONOTHEISM AND ITS IMPACT ON LAYING } \\
\text { THE FOUNDATIONS OF SOCIETY } \\
\text { (SURAT AL-IKHLAS AS A MODEL) }\end{array}$ & P. 72-82 \\
\hline $\begin{array}{l}\text { Layla Ashour } \\
\text { Hajim AL- } \\
\text { KHAZRAGY } \\
\text { Bushra Ashour } \\
\text { Hajem AL- } \\
\text { KHAZRAGY }\end{array}$ & $\begin{array}{l}\text { WAYS TO ADDRESS THE WATER CRISES } \\
\text { AND ACHIEVE WATER SECURITY } \\
\text { (WATER DIPLOMACY AS A MODEL) }\end{array}$ & P.83-100 \\
\hline $\begin{array}{l}\text { Bekir } \\
\text { MEHMETALI }\end{array}$ & $\begin{array}{c}\text { THE SUBJECT BETWEEN SYNTAX AND } \\
\text { SEMANTICS }\end{array}$ & P. 101-109 \\
\hline Turgay GÖKGÖZ & $\begin{array}{c}\text { OVERVIEW OF CENSOR PHENOMENON IN } \\
\text { MODERN ARABIC LITERATURE }\end{array}$ & P. 110-121 \\
\hline
\end{tabular}


THE MOST USED LEARNING SKILLS IN LEARNING PROCESS FOR STUDENTS OF ALZAYTONA UNIVERSITY, PALESTINE: ARABIC COURSE AS A MODEL

Sawsan Ahmad NABRESI 


\title{
THE MOST USED LEARNING SKILLS IN LEARNING PROCESS FOR STUDENTS OF AL-ZAYTONA UNIVERSITY, PALESTINE: ARABIC COURSE AS A MODEL
}

\author{
Sawsan Ahmad NABRESI ${ }^{1}$
}

\begin{abstract}
:
This study primarily aims at identifying learning skills which Al-zaytona University students make use of in learning the Arabic Language course. In order to accomplish this work, the researcher implements a questionnaire, consisting of twenty-two points, arrayed at three aspects: the behavioral, the epistemological and existential aspect. The outcomes are valid and reliable. The sample presented consists of thirty-two students, males and females. The study reaches some conclusions; one of which is that there was a grand, positive tendency towards implementing learning skills amongst Al-zaytona University students as well as making use of the epistemological and existential skills; after that, there comes the behavioral skills. The study finally hints given the variant sex, the university study degree, college and specialization, there were barely statistical differences in using learning skills.

Key words: Learning Skills, The Behavioral, The Epistemological and Existential Aspect, Al-Zaytona University, Arabic Language Course.
\end{abstract}

http://dx.doi.org/10.47832/ijhercongress2-1

${ }^{1}$ Al-Zaytoonah University of Science and Technology, Palestine, sawsannabresi@ hotmail.com, https://orcid.org/0000-00019029-0117 
مهارات التعلّم الأكثر استخدامًا في العملية التعليمية لدى طلبة جامعة الزيتونة/فلسطين مساق اللغة العربية أنموذجًا

سوسن أحمد نبريصي 2

الملخص:

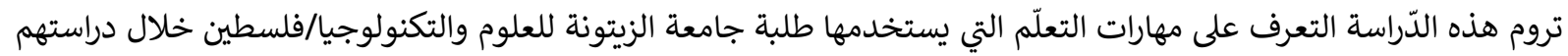

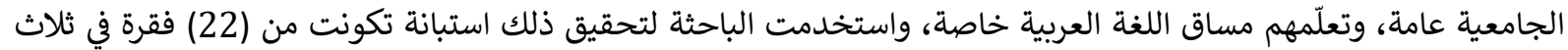

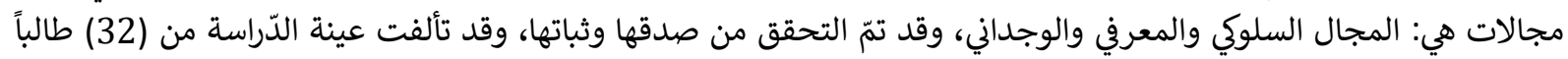
وطالبة. وتتغيا الدّراسة الإجابة عن التساؤلات الآتية:

السؤال الأول: ما مهارات التعلّم الأكثر استخداماً في العملية العملية التعليمية لدى طلبة جامعة الزيتونة/فلسطين مساق اللغة العربية

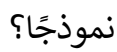

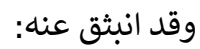

ما مهارات التعلّم السلوكية الأكثر استخداماً في العملية التعليمية لدى طلبة جامعة الزيتونة/فلسطين مساق اللغة العربية نموذجًا؟

ما مهارات التعلّم المعرفية الأكثر استخداماً في العملية التعليمية لدى طلبة جامعة الزيتونة/فلسطين مساق اللغة العربية

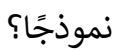
ما مهارات التعلّم الوجدانية الأكثر استخداماً في العملية التعليمية لدى طلبة جامعة الزيتونة/فلسطين مساق اللغة العربية نموذجًا؟ السؤال الثاني: هل توجد فروق ذات دلألة الدألة إحصائية في مستوى استخدام مهارات التعلّم لدى طلبة جامعة الزيتونة تبعًا للمتغيرات الآتية؛ الجنس، المرحلة فروف الترات الدراسية، الكلية، التخصص؟

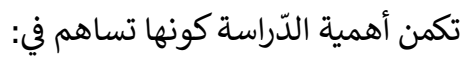

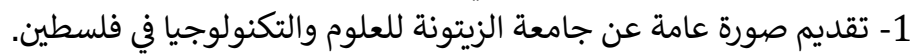

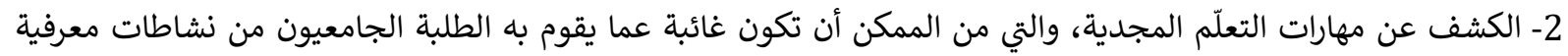

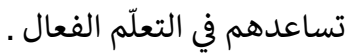
3- تساهم في إفادة أعضاء هيئة التدريس وأولياء أمور الطلبة بمهارات تعلّم الطالب الجامعي، وذلك من خلال تهيئة الظروف المناسبة لممارسة مهارات التعلّم التي تؤدي إلى تعلّم فئل فيّال.

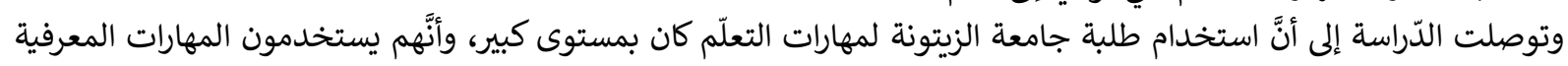

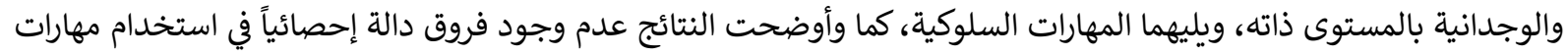

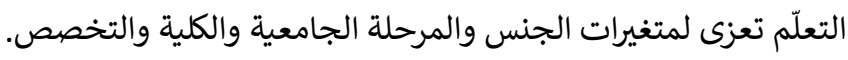

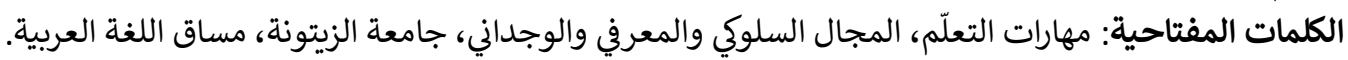

1- 1 مشكلة الدراسة وأسئلتها

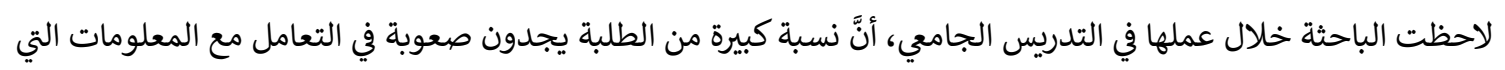

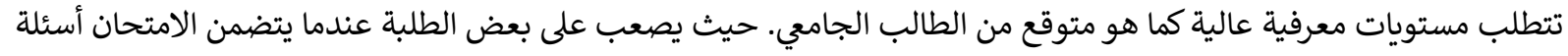

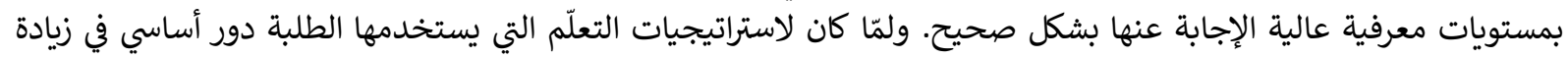

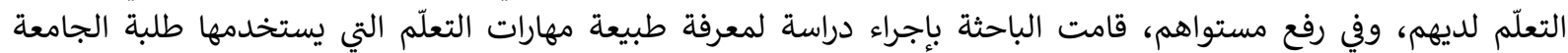
وعلاقتها ببعض المتغيرات الديمغرافية.

ومن هنا تتجلّى مشكلة الدّراسة في محاولة الإجابة عن الأسئلة الآتية:

السؤال الأول: ما مهارات التعلّم الأكثر استخداماً في العملية التعليمية لدى طلبة جامعة الزيتونة/فلسطين مساق اللغة العربية

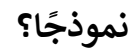


• ما مهارات التعلّم السلوكية الأكثر استخداماً في العملية التعليمية لدى طلبة جامعة الزيتونة/فلسطين مساق اللغة العربية نموذجًا؟ • ما مهارات التعلّم المعرفية الأكثر استخداماً في العملية التعليمية لدى طلبة جامعة الزيتونة/فلسطين مساق اللغة العربية نموذجًا؟ • ما مهارات التعلّم الوجدانية الأكثر استخداماً في العملية التعليمية لدى طلبة جامعة الزيتونة/فلسطين مساق اللغة العربية

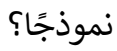
السؤال الثاني: هل توجد فروق ذات دلالة إحصائية في مستوى استخدام مهارات التعلّم لدى طلبة جامعة الزيتونة تبعًا للمتغيرات الآتية؛ الجنس، المرحلة التوجل فروف ذات الدراسية، الكلية، التخصص؟ إحصية في مسيتو؟

2- 2 - 2 أهداف الدّراسة تسعى الدّراسة إلى بلوغ الأهداف التالية: 1. التعرف إلى جامعة الزيتونة للعلوم والتكنولوجيا في فلسطين.

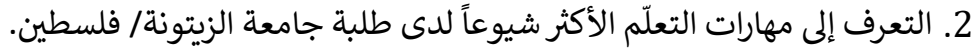

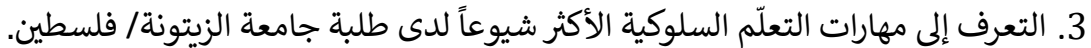

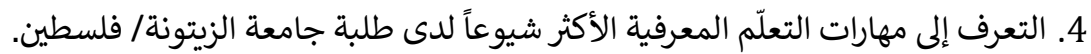

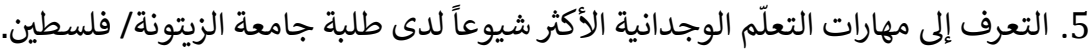

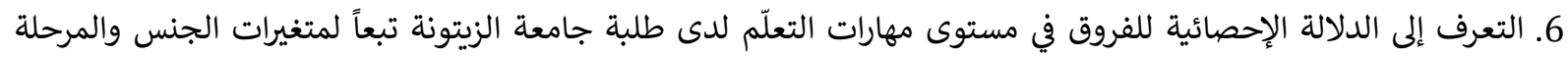
الدراسية، والكلية و التخصص.

3- أهمية الدّراسة

$$
\text { تساهم هذه الدّراسة في: }
$$

1. تقديم صورة عامة عن جامعة الزيتونة للعلوم والتكنولوجيا في فلسطين.

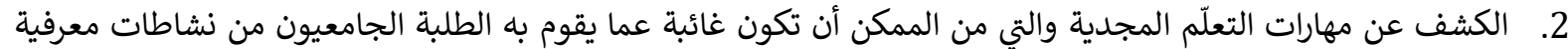
تساعده في التعلّم الفعال. 3. تساهم في إفادة أعضاء هيئة التدريس وأولياء أمور الطلبة بمهارات تعلّم الطالب الجامي،، وذلك من خلال تهيئة الظروف المناسبة لممارسة مهارات التعلّم التي تؤدي إلى تعلّم فعّال.

4- 1 فرضيات الدّراسة

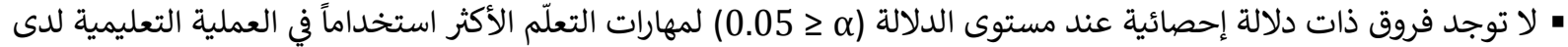

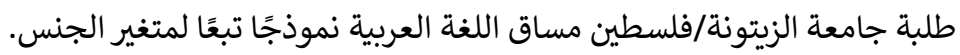

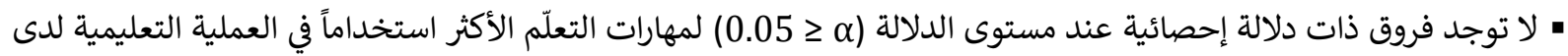

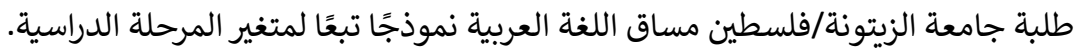

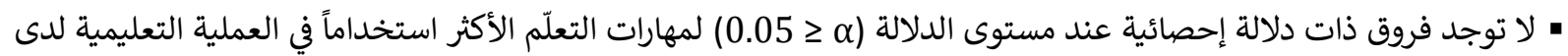
طلبة جامعة الزيتونة/فلسطين مساق اللغة العربية نموذجًا تبعًا لمتغير الكلية.

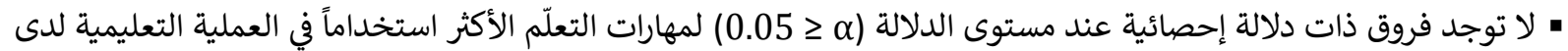

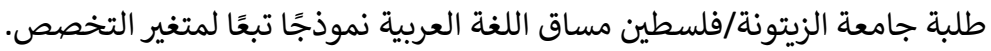

\section{5- منهج الدّراسة}

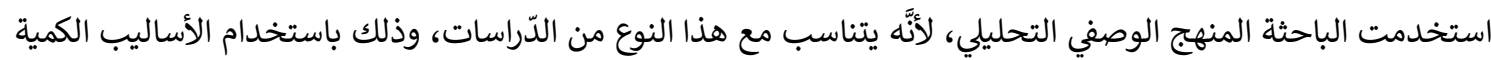

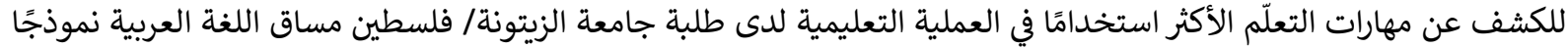

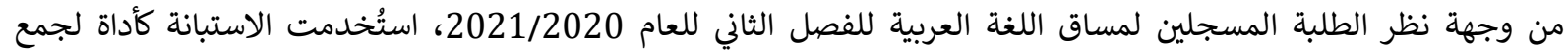
المعلومات المتعلقة بموضوع البحث. لمطن. 
II. International Congress of Humanities and Educational Research (IJHER Congress 2)

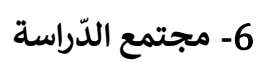

تضمن مجتمع البحث طلبة الدبلوم والبكالوريوس في جامعة الزيتونة/ فلسطين والمسجلين لمساق اللغة العربية للفصل

الثاني للعام 2021/2020، وقد بلغ عددهم (35) طالب وطالبة.

المحور الأول: الإطار النظري

أولاً: مهارات التعلّم

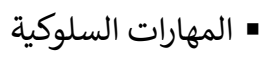

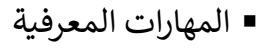

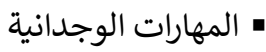

ثانيًا: جامعة الزيتونة للعلوم والتكنولوجيا/سلفيت _فلسطين

المحور الثاني: إجراءات الدّراسة

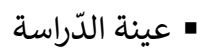

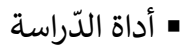

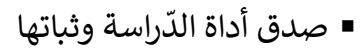

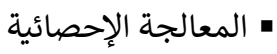

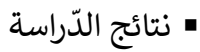

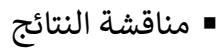

الخلاصة 


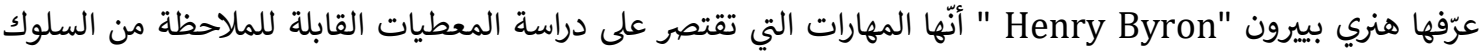

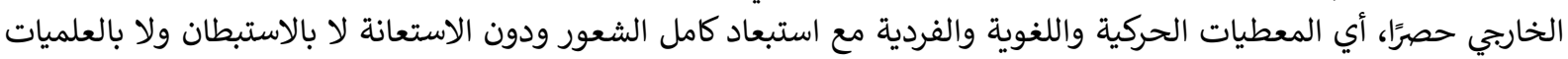
الفيزيولوجية، وقد تبلورت هذه النظرية على يد رائدها واطسونسية Watso.(جمل محمد: العمليات الذهنية ومهارات

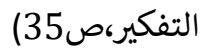

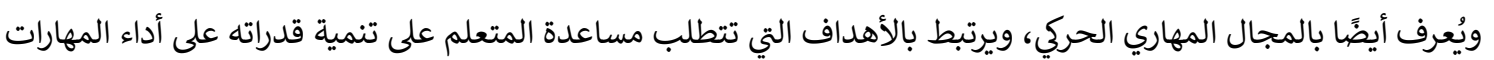

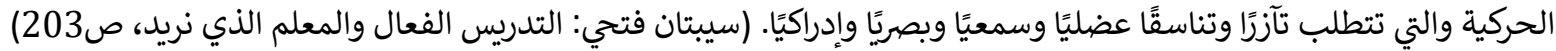

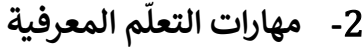

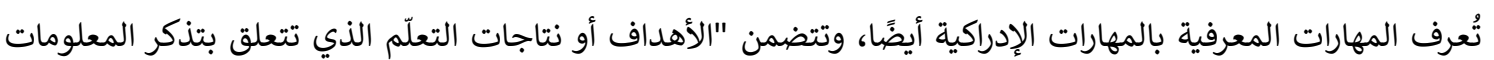

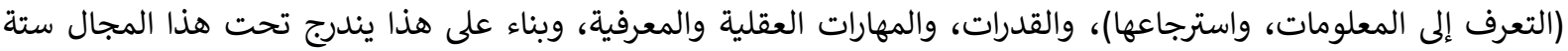

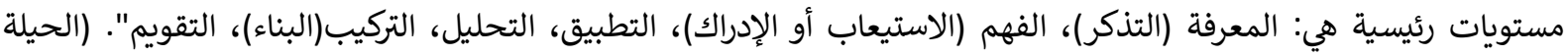

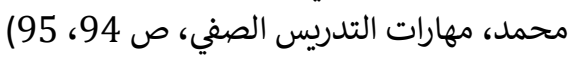

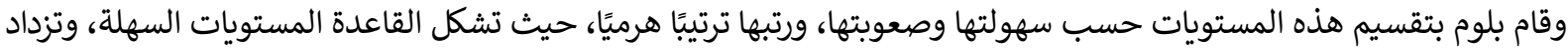

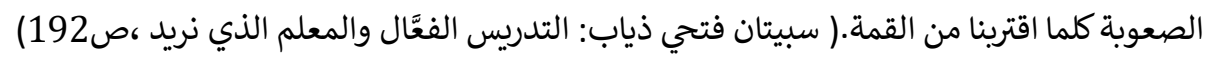

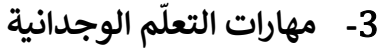

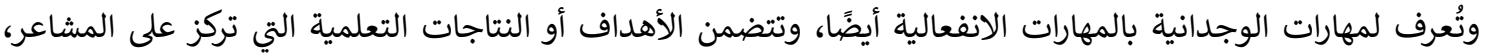

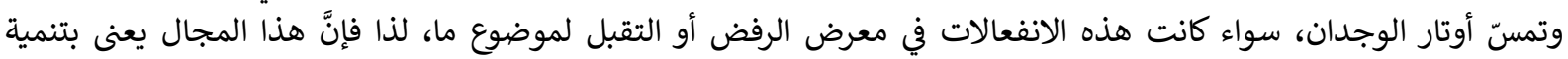

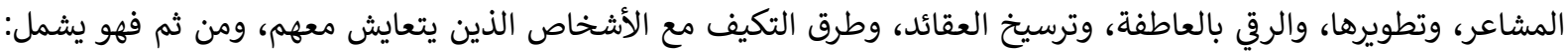

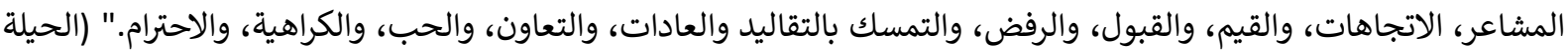

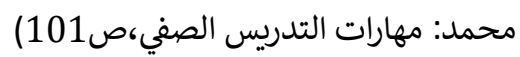

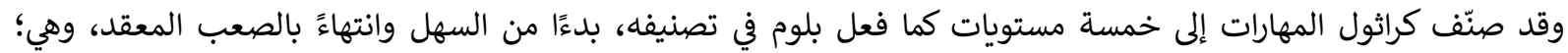

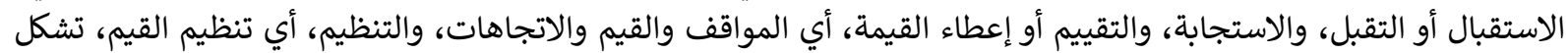

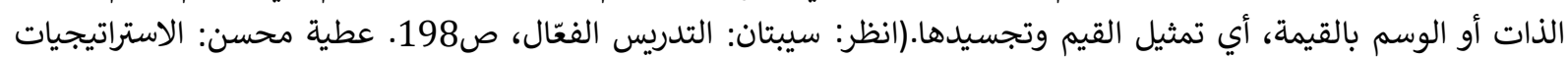

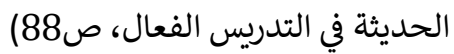

\section{ثانيًا: جامعة الزيتونة للعلوم والتكنولوجيا/سلفيت_فلسطين3}

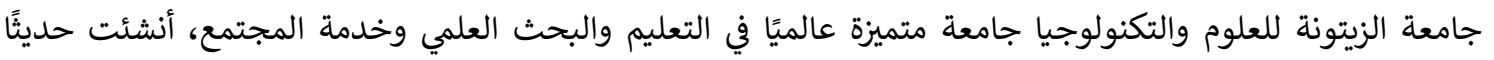

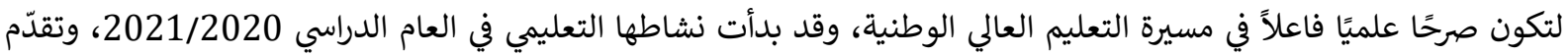

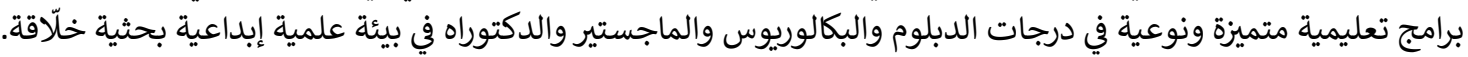

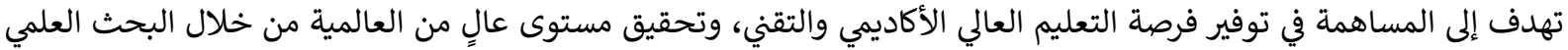

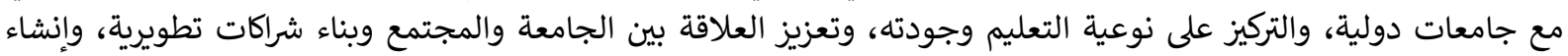
مراكز متميزة في البحث العلمي.

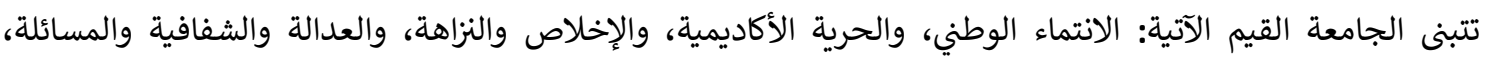

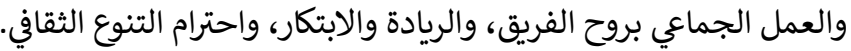

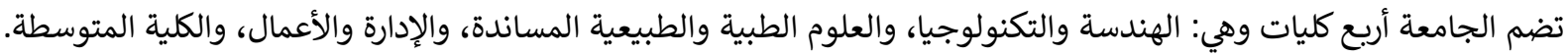

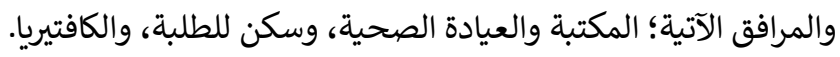


II. International Congress of Humanities and Educational Research (IJHER Congress 2)

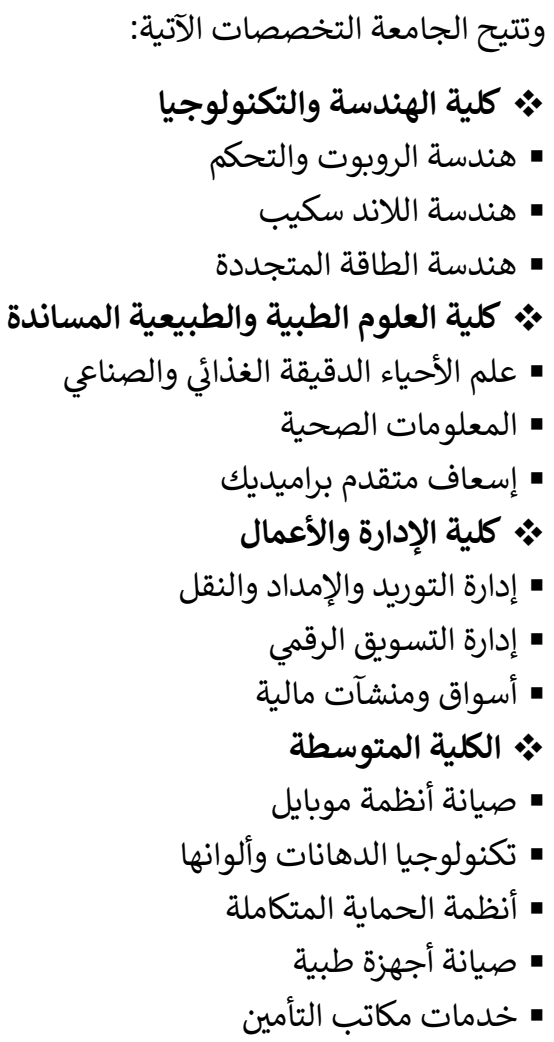


اشتملت عينة الدّراسة على 35 من طلبة الدبلوم والبكالوريوس والمسجلين لمساق اللغة العربية في جامعة الزيتونة للعلوم والتكنولوجيا/ فلسطين للفصل الدراسي الثاني للعام 2021/2020، وقد تمّ توزيع عينة الدّراسة (35) طالباً وطالبة عشوائياً، علماً

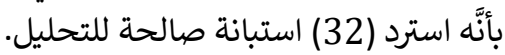

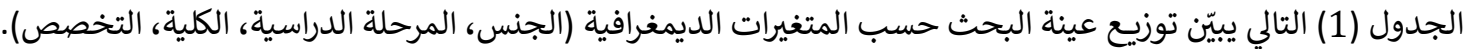
الجدول (1) توزيع عينة البحث حسب المتغيرات الديمغرافية

\begin{tabular}{|c|c|c|c|}
\hline النسبة المئوية & العدد & المستوى & المتغير \\
\hline $78 \%$ & 25 & 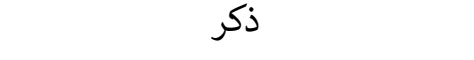 & \multirow{2}{*}{ 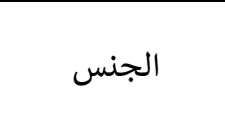 } \\
\hline $22 \%$ & 7 & أنثى & \\
\hline $47 \%$ & 15 & 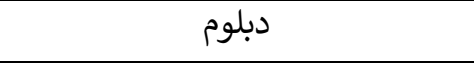 & \multirow{2}{*}{ المرحلة الدراسية } \\
\hline $53 \%$ & 17 & بكالوريوس & \\
\hline $13 \%$ & 4 & الهندسة والتكنولوجيا & \multirow{4}{*}{ 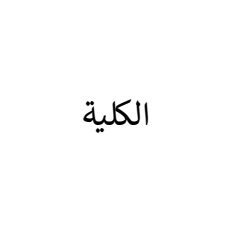 } \\
\hline $19 \%$ & 6 & العلوم الطبية والطبيعية المساندة & \\
\hline $25 \%$ & 8 & الإدارة والأعمال & \\
\hline $44 \%$ & 14 & الكلية المتوسطة & \\
\hline $6 \%$ & 2 & هندسة الروبوت والتحكم & \multirow{9}{*}{ التخصص } \\
\hline $3 \%$ & 1 & هندسة الطاقة المتجددة & \\
\hline $3 \%$ & 1 & علم الأحياء الدقيقة الغذائي والصناعي & \\
\hline $16 \%$ & 5 & إسعاف متقدم براميديك & \\
\hline $22 \%$ & 7 & إدارة التسويق الرقمي & \\
\hline $3 \%$ & 1 & أسواق ومنشآت مالية & \\
\hline $3 \%$ & 1 & صيانة أنظمة موبايل & \\
\hline $6 \%$ & 2 & أنظمة الحماية المتكاملة & \\
\hline $38 \%$ & 12 & صيانة أجهزة طبية & \\
\hline
\end{tabular}

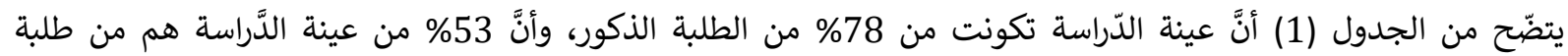

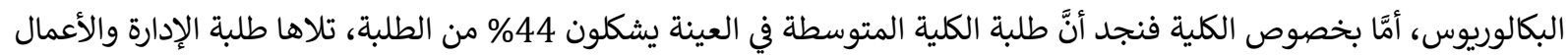

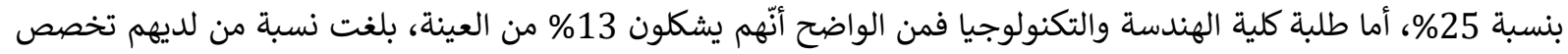

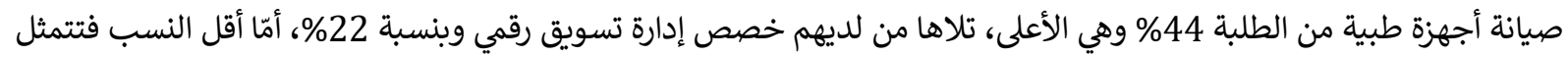

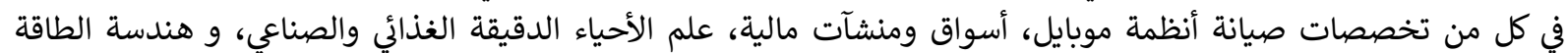

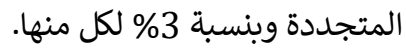

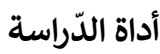

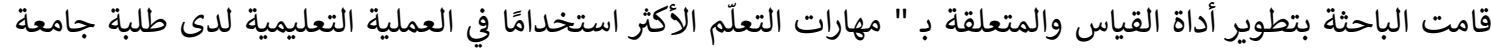

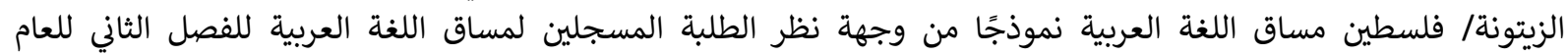

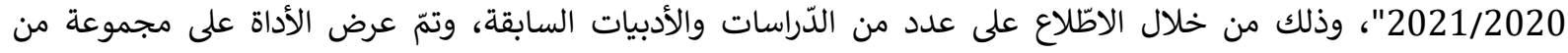

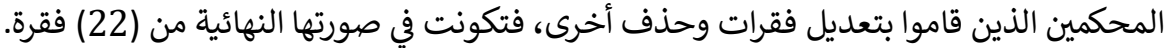

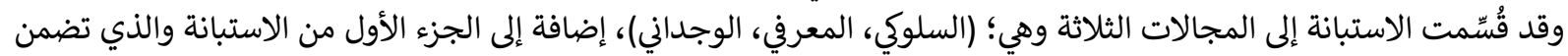

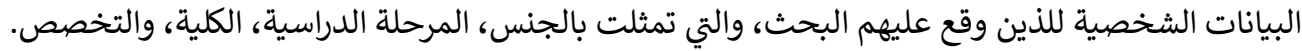




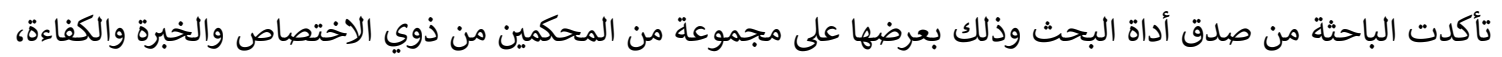

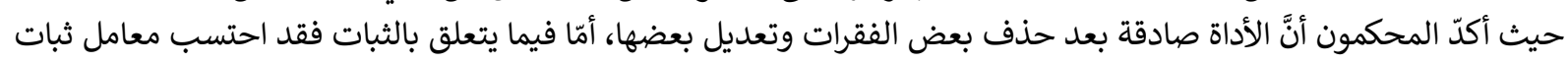

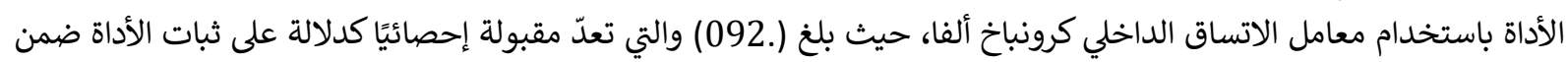
مجتمع البحث.

\section{المعالجة الإحصائية}

استخدمت الباحثة طرقاً وصفية وتحليلية، وتمثلت الطرق الإحصائية الوصفية باحتساب المتوسطات الحسابية،

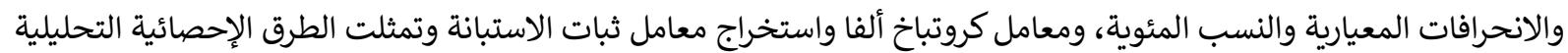
باختبار (ت) (t-test)، هذا بالإضافة إلى تحليل التباين الأحادي (One Way ANOVA).

نتائج الدّراسة

السؤال الرئيس: ما مهارات التعلّم الأكثر استخداماً في العملية التعليمية لدى طلبة جامعة الزيتونة/فلسطين مساق اللغة

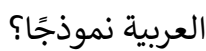
ولتفسير النتائج اعتمدت النسب المئوية للمتوسطات الحسابية الآتية المعتمدة إحصائيًا، والخاصة بالإجابة على المقائ الفقرات:

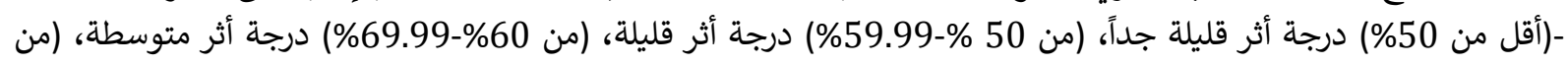

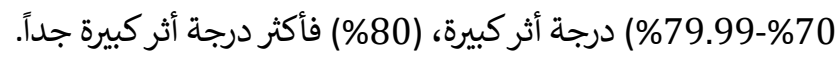
الجدول(2) (2) (2) (2)

المتوسطات الحسابية والانحرافات المعيارية ودرجة الأثر لمهارات التعلّم الأكثر استخداماً في العملية التعليمية لدى طلبة جامعة

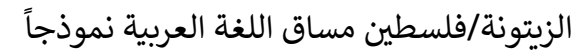

\begin{tabular}{|c|c|c|c|c|}
\hline الأثر & المئوية & الحسابي & الانحراري & المجال \\
\hline كبيرة & $75 \%$ & 3.77 & 0.60 & السلوكي \\
\hline كبيرة جداً & $80 \%$ & 4.02 & 0.65 & المعرفي \\
\hline كبيرة جداً & $80 \%$ & 3.98 & 0.70 & الوجداني \\
\hline كبيرة & $78 \%$ & 3.92 & 0.60 & الدرجة الكلية \\
\hline
\end{tabular}

يتضّح من خلال الجدول (2) السابق أنَّ درجة الأثر لمهارات التعلّم الأكثر استخداماً في العملية التعليمية لدى طلبة جامعة

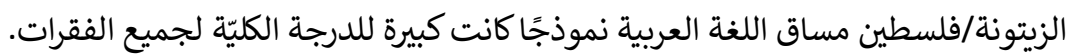

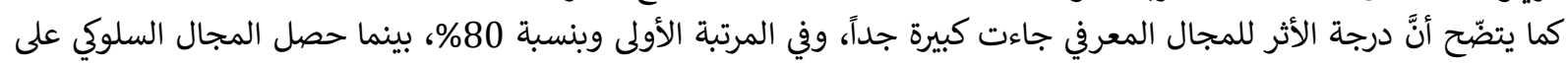

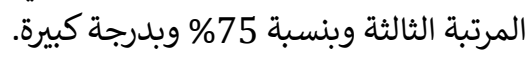
وفيما يلي الإجابة عن الأسئلة الفرعية التي اشتقت من من السؤال الرئيس:

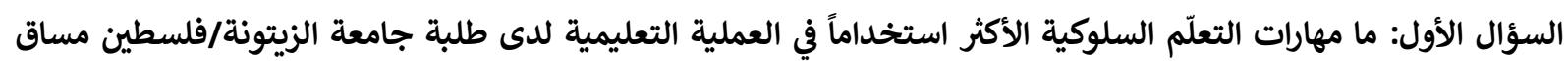
اللغة العربية نموذجًا؟ الأول: مأمات

الجدول(3) المتوسطات الحسابية والانحرافات المعيارية ودرجة الأثر لمهارات التعلّم السلوكية الأكثر استخداماً في العملية التعليمية لدى طلبة جامعة الزيتونة/فلسطين مساق اللغة العربية نموذجًا

\begin{tabular}{|c|c|c|c|c|}
\hline الأثر & المئوية & الحسابي & المعياري & 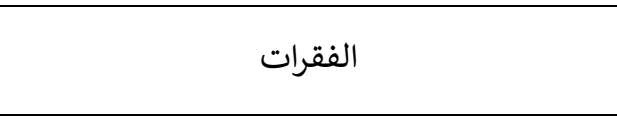 \\
\hline كبيرة جداً & $82 \%$ & 4.12 & 0.83 & أضع إشارات أو عناوين على الأجزاء المراد حفظها. \\
\hline 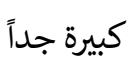 & $83 \%$ & 4.13 & 0.83 & أضع خطوظًا تحت الأجزاء المهمة من المادة. \\
\hline
\end{tabular}


Full Text Book of IJHER Congress 2

\begin{tabular}{|c|c|c|c|c|}
\hline 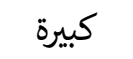 & $72 \%$ & 3.59 & 0.98 & أقوم بتسميع جهري للمعلومات التي أريد حفظها. \\
\hline 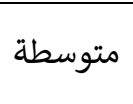 & $62 \%$ & 3.09 & 0.25 & أضع أسئلة متوقعة عند تحضيري للامتحانات وأحاول \\
\hline كبيرة & $71 \%$ & 3.56 & 0.91 & أدوّن الملاحظات التي يقولها المدرس حرفيًا في \\
\hline 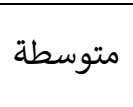 & $69 \%$ & 3.44 & 0.91 & أطبّق المهارات اللغوية التي أدرسها عمليًا؛ قراءة وكتابة \\
\hline كبيرة جداً & $85 \%$ & 4.25 & 0.14 & أجلس في مكان يساعدني على متابعة دروسي والدراسة \\
\hline كبيرة & $79 \%$ & 3.94 & 0.91 & أحافظ على الحضور الدائم في المحاضرات ودون تأخير \\
\hline كبيرة & $75 \%$ & 3.77 & 0.60 & الدرجة الكلية \\
\hline
\end{tabular}

نلاحظ من خلال البيانات الواردة في الجدول (3) أنَّ النسبة المئوية للمتوسطات الحسابية لفقرات مجال مهارات التعلّم السلوكية

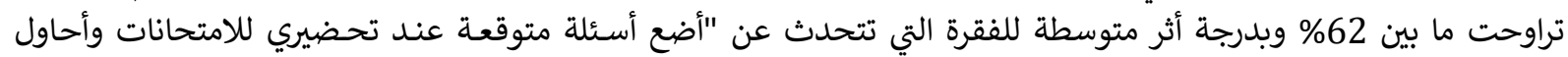

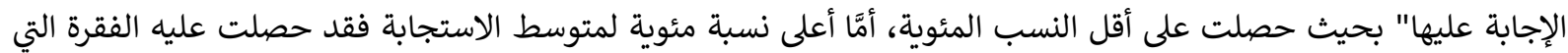

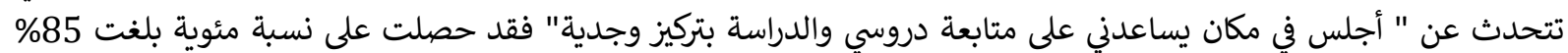
وبدرجة أثر كبيرة جدًا.

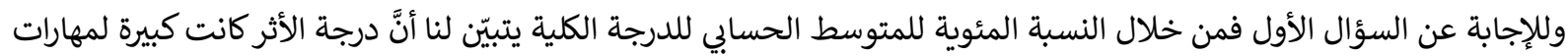

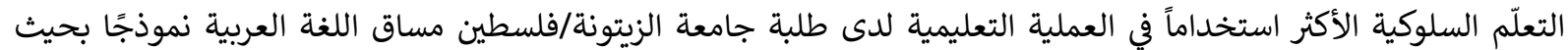

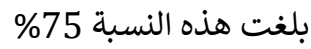

\begin{tabular}{|c|c|c|c|c|}
\hline الأثر & 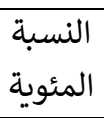 & 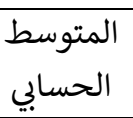 & 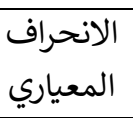 & 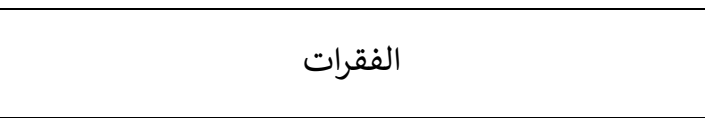 \\
\hline كبيرة جداً & $76 \%$ & 3.78 & 0.40 & أقوم بتسميع المعلومات التي أريد حفظها في ذهني \\
\hline كبيرة جداً & $90 \%$ & 4.5 & 0.72 & أفهم الأفكار الأساسية بدل حفظها صمًا. \\
\hline كبيرة & $72 \%$ & 3.62 & 0.16 & أعمل قراءة تصفحية للمادة أولَاُ، ثم أعود مرة أخرى \\
\hline 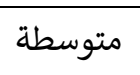 & $74 \%$ & 3.72 & 0.99 & أمارس المذاكرة الطويلة المكثفة، خاصة قبل الامتحانات. \\
\hline كبيرة & $79 \%$ & 3.97 & 0.96 & أعتمد بشكل كلي على المدرس في فهم محتويات المقرر \\
\hline متوسطة & $89 \%$ & 4.47 & 0.80 & أفهم المادة التي أرغب في تذكرها بدقة. \\
\hline كبيرة جداً & $81 \%$ & 4.06 & 0.91 & أحاول إيجاد روابط بين أجزاء المادة. \\
\hline كبيرة جداً & $80 \%$ & 4.02 & 0.65 & الدرجة الكلية \\
\hline
\end{tabular}

السؤال الثاني: ما مهارات التعلّم المعرفية الأكثر استخداماً في العملية التعليمية لدى طلبة جامعة الزيتونة/فلسطين مساق اللغة العربية نموذجًا؟ المأي

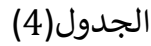
المتوسطات الحسابية والانحرافات المعيارية ودرجة الأثر لمهارات التعلّم المعرفية الأكثر استخداماً في العملية التعليمية لدى طلبة جامعة الزيتونة/فلسطين مساق اللغة العربية نموذجًا.

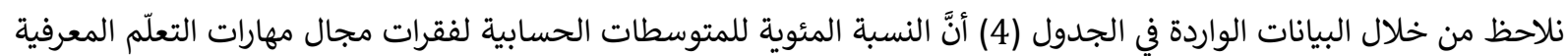

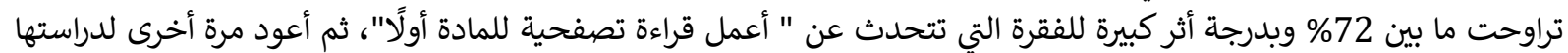

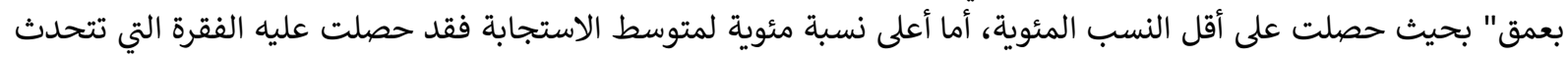

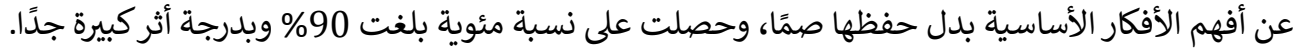


II. International Congress of Humanities and Educational Research (IJHER Congress 2)

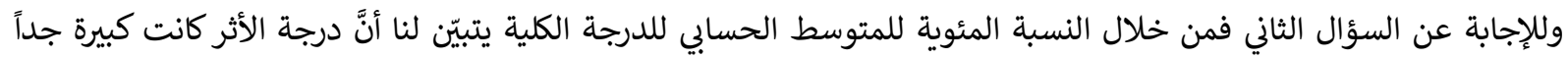

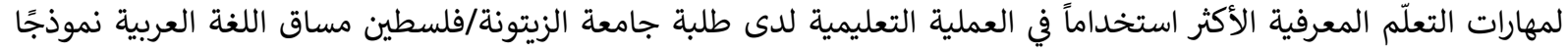

بحيث بلغت هذه النسبة 80\%.

السؤال الثالث: ما مهارات التعلّم الوجدانية الأكثر استخداماً في العملية التعليمية لدى طلبة جامعة الزيتونة/فلسطين مساق

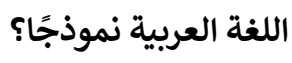

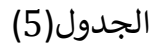

المتوسطات الحسابية والانحرافات المعيارية ودرجة الأثر لمهارات التعلّم الوجدانية الأكثر استخداماً في العملية التعليمية لدى

طلبة جامعة الزيتونة/فلسطين مساق اللغة العربية نموذجًا

\begin{tabular}{|c|c|c|c|c|}
\hline 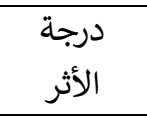 & 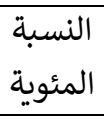 & الحستوسط المسابي & 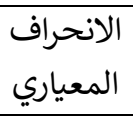 & 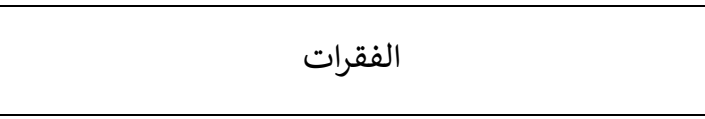 \\
\hline كبيرة & $78 \%$ & 3.91 & 0.20 & أصوغ الأفكار المهمة على دفتري بلغتي الخاصة. \\
\hline كبيرة & $79 \%$ & 3.97 & 0.12 & أدرس المادة على فترات يتخللها أوقات راحة قصيرة. \\
\hline 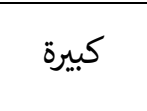 & $72 \%$ & 3.62 & 0.16 & أعيد تنظيم موضوعات المادة بشكل مريح ثم أقرأها من \\
\hline كبيرة & $76 \%$ & 3.81 & 0.99 & أصنّف وأبوّب المعلومات الموجودة في المادة لتسهيل \\
\hline كبيرة جداً & $83 \%$ & 4.13 & 0.94 & أهتم بطريقة وأسلوب كتابتي، وأستى لتحسينها \\
\hline 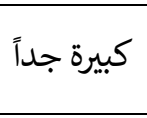 & $82 \%$ & 4.09 & 0.12 & أعزز نفسي وأحفزها لمواجهة التحديات باستحضار نماذج \\
\hline كبيرة جداً & $87 \%$ & 4.34 & 0.75 & راضٍ عن قدرتي على القراءة الواعية وفهم المقروء \\
\hline كبيرة جداً & $80 \%$ & 3.98 & 0.70 & الدرجة الكلية \\
\hline
\end{tabular}

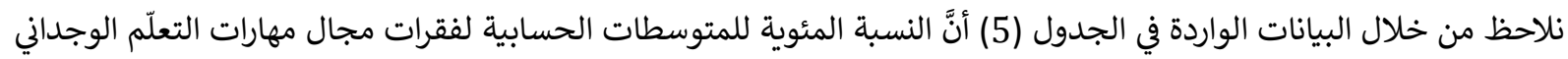

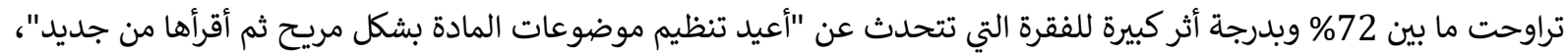

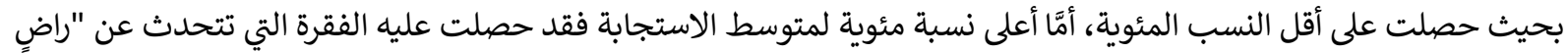

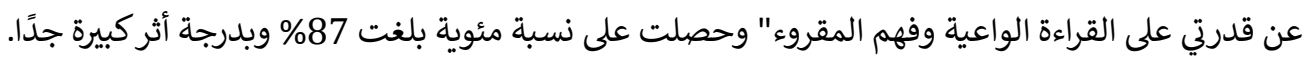

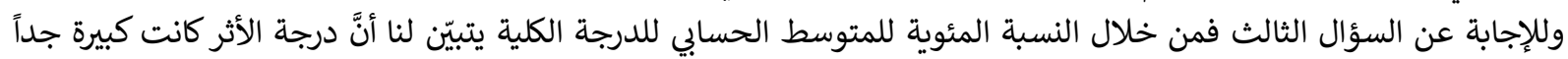
لمهارات التعلّم الوجداني الأكثر استخداماً في العملية التعليمية لدى طلبة جالية التعالة الزية الزيتونة/فلسطين مساق اللغة العربية نموذجًا

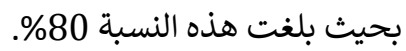

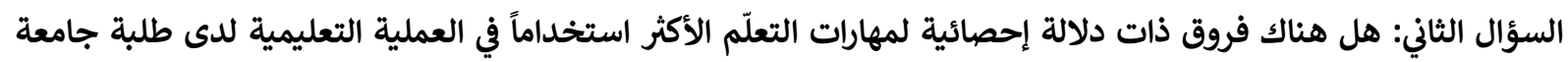

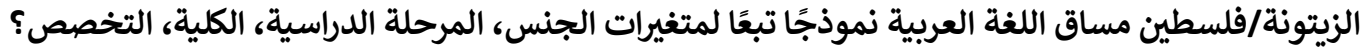

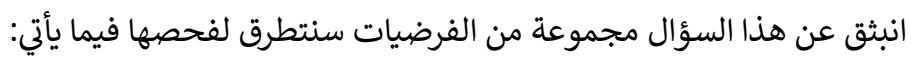

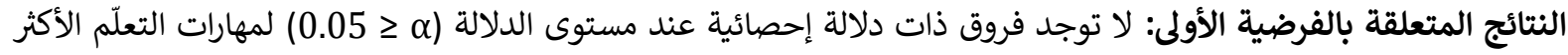

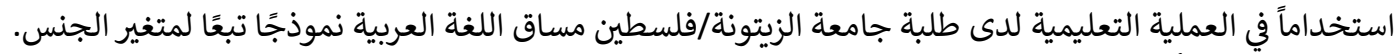

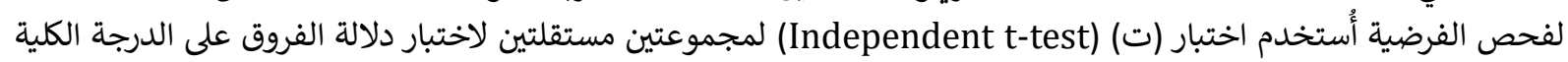
لجميع فقرات الأداة تبعًا لمتغير الجنس. الجدول(6) اختبار (ت) (Independent t-test) لمجموعتين مستقلتين لقياس المتوسطات تبعًا لمتغير الجنس

\begin{tabular}{|c|c|c|c|c|c|c|}
\hline \multirow[b]{2}{*}{ الدلالة* } & \multirow[b]{2}{*}{ (ت) } & \multicolumn{2}{|l|}{ أنثى } & \multicolumn{2}{|l|}{ ذكر } & \multirow{3}{*}{ الدرجة الكلية } \\
\hline & & المعياري & الحسابي & الانحياري & الحسابي & \\
\hline 0.70 & 0.39 & 0.50 & 3.84 & 0.63 & 3.95 & \\
\hline
\end{tabular}




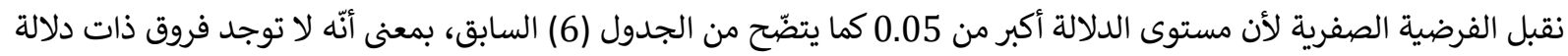

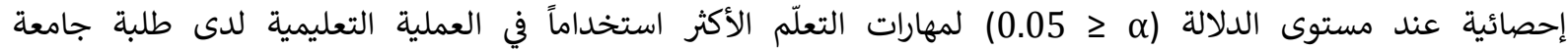

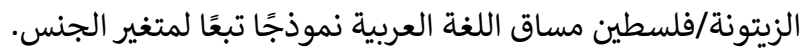

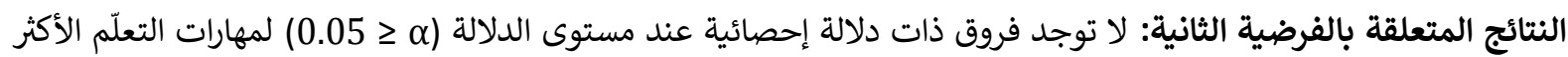

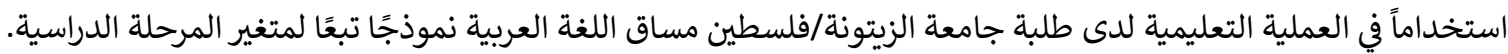

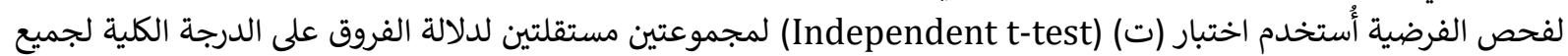
فقرات الأداة تبعا لمتغير المرحلة الدراسية. كما يوضّحه الجدول (t) الفتبار (7) التالي:

الجدول (7) اختبار (ت) (Independent t-test) لمجموعتين مستقلتين لقياس المتوسطات الحسابية تبعًا لمتغير المرحلة الدراسية

\begin{tabular}{|c|c|c|c|c|c|c|}
\hline \multirow[b]{2}{*}{ | الدلالة* } & \multirow[b]{2}{*}{ (ت) } & بكالوريوس & & دبلوم & & \multirow{3}{*}{ الدرجة الكلية } \\
\hline & & الانعياري & الحسوسابي & المعياري & الحسابي & \\
\hline 0.22 & 1.27 & 0.69 & 3.80 & 0.46 & 4.06 & \\
\hline
\end{tabular}

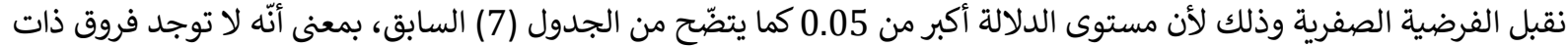

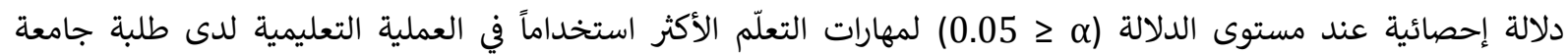
الزيتونة/فلسطين مساق اللغة العربية نموذجاً تبعًا لمتغير المرحلة الدراسية.

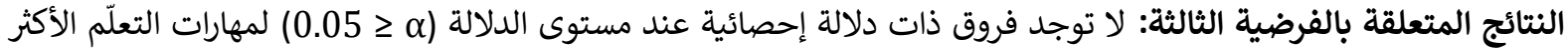

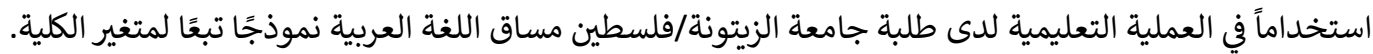

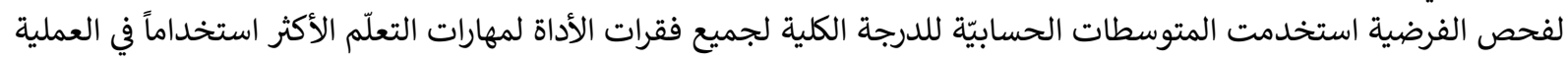
التعليمية لدى طلبة جامعة الزيتونة/فلسطين مساق اللغة العربية نموذجًا تبعًا لمتغير الكلية. الجدول (8) المتوسطات الحسابية للدرجة الكلية تبعاً لمتغير الكلية

\begin{tabular}{|c|c|c|c|c|}
\hline الكلية المتوسطة & الإدارة والأعمال & العلوم الطبية والطبيعية المساندة & الهندسة والتكنولوجيا & الدرجة \\
\hline 4.05 & 3.89 & 3.58 & 4.04 & الكلية \\
\hline
\end{tabular}

وتمَّ أيضاً استخدام تحليل التباين الأحادي (ANOVA) لاستخراج دلالة الفروق للدرجة الكلية لجميع فقرات الأداة تبعًا لمتغير الكلية عند العينة. والجدول (9) يبيّن ذلك.

الجدول (9) نتائج تحليل التباين الأحادي (ANOVA) للدرجة الكلية تبعًا لمتغير الكلية

\begin{tabular}{|c|c|c|c|c|c|c|}
\hline مستوى & ف & متوسط المربعات & درجات الحرية & المربعات & مصدر التباين & \multirow{4}{*}{ الدرجة الكلية } \\
\hline \multirow{3}{*}{0.44} & \multirow{3}{*}{0.93} & 0.34 & 3 & 1.01 & بين المجموعات & \\
\hline & & 0.36 & 28 & 10.09 & داخل المجموعات & \\
\hline & & & 31 & 11.09 & المجموع & \\
\hline
\end{tabular}

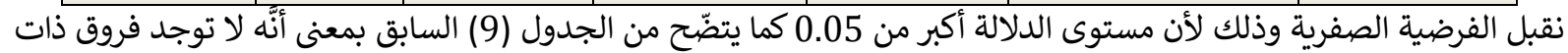

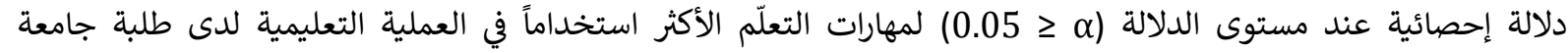
الزيتونة/فلسطين مساق اللغة العربية نموذجًا تبعًا لمتغير الكلية.

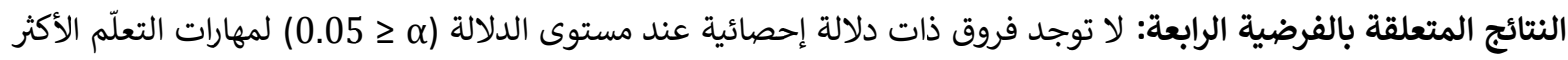

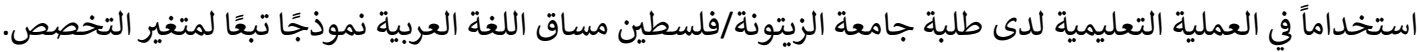

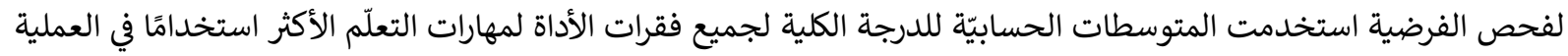

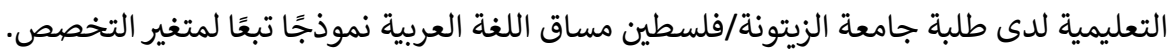


II. International Congress of Humanities and Educational Research (IJHER Congress 2)

الجدول (10) المتوسطات الحسابية للدرجة الكلية تبعًا لمتغير التخصص

\begin{tabular}{|c|c|}
\hline المتوسط الحسابي & التخصص \\
\hline 4.19 & هندسة الروبوت والتحكم \\
\hline 3.57 & هندسة الطاقة المتجددة \\
\hline 3.50 & علم الأحياء الدقيقة الغذائي والصناعي \\
\hline 3.59 & إسعاف متقدم براميديك \\
\hline 3.90 & إدارة التسويق الرقمي \\
\hline 3.88 & أسواق ومنشآت مالية \\
\hline 4.44 & صيانة أنظمة موبايل \\
\hline 3.94 & أنظمة الحماية المتكاملة \\
\hline 4.05 & صيانة أجهزة طبية \\
\hline
\end{tabular}

وتمَّ أيضاً استخدام تحليل التباين الأحادي (ANOVA) لاستخراج دلالة الفروق للدرجة الكلية لجميع فقرات الأداة تبعاً لمتغير التخصص عند العينة. والجدول (11) يبيّن ذلك.

الجدول (11) نتائج تحليل التباين الأحادي (ANOVA) للدرجة الكلية تبعًا لمتغير التخصص دول دينين

\begin{tabular}{|c|c|c|c|c|c|c|}
\hline الدلالة* مستوى & ف & متوسط & درجات الحرية & المربعات & مصدر التباين & \multirow{4}{*}{ الدرجة الكلية } \\
\hline \multirow{3}{*}{0.89} & \multirow{3}{*}{0.44} & 0.18 & 8 & 1.46 & بين المجموعات & \\
\hline & & 0.42 & 23 & 9.63 & داخل المجموعات & \\
\hline & & & 31 & 11.09 & المجموع & \\
\hline
\end{tabular}

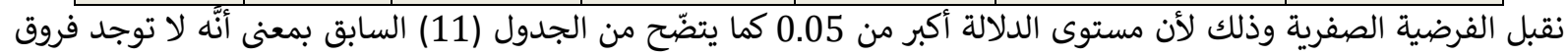

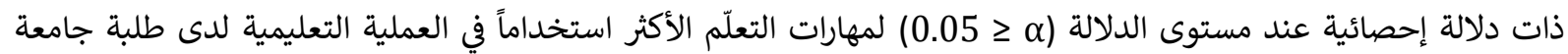

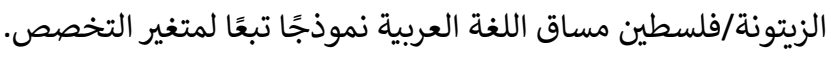

مناقشة النتائج

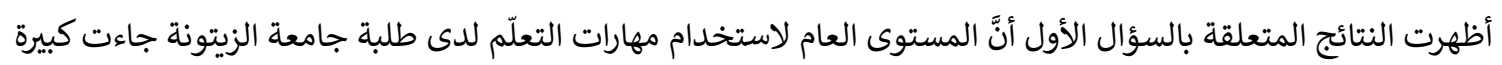

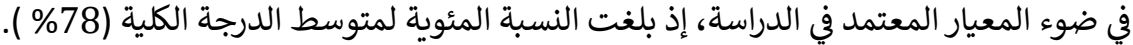

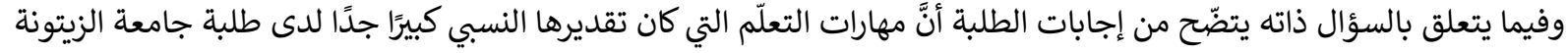

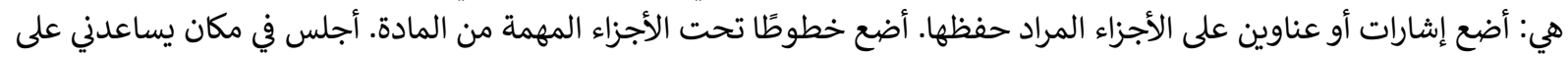

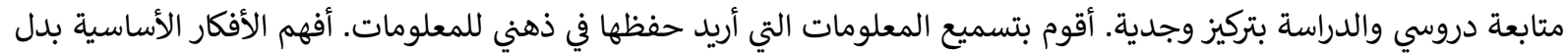

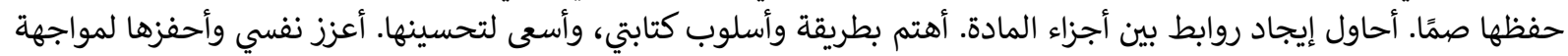

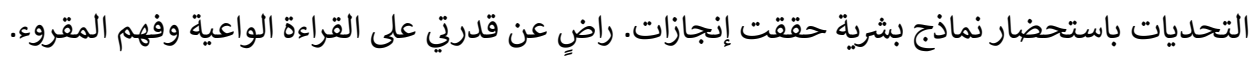

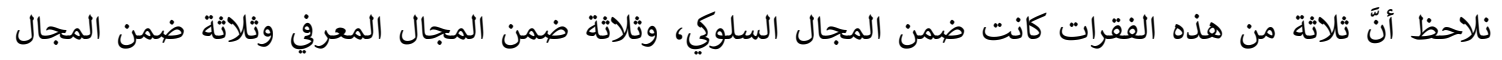

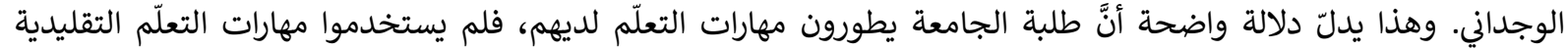

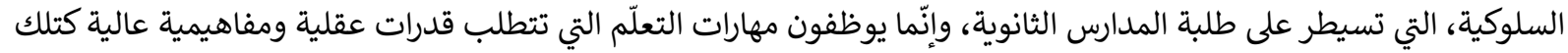

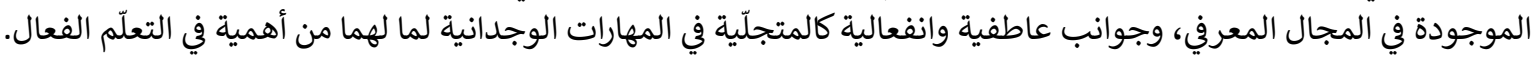

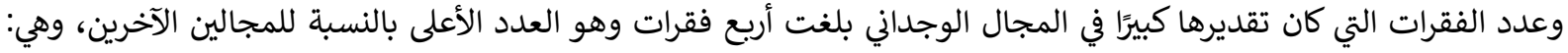

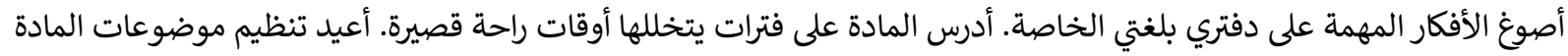

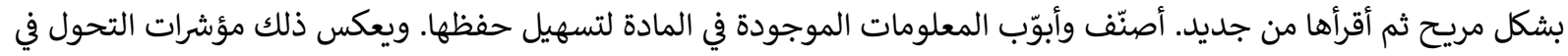

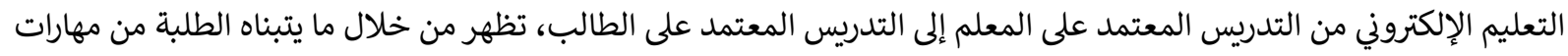

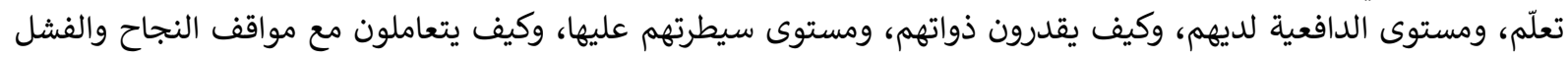
الأكاديمي.

وفيما يتعلق بالسؤال الثاني، فقد أظهرت نتاج الدّراسة عدم وجود فروق والجية ذات وات دلالة إحصائية في استخدام مهارات التعلّم

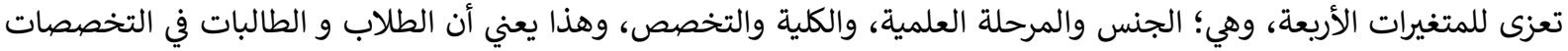




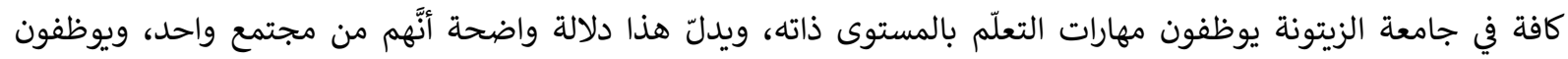

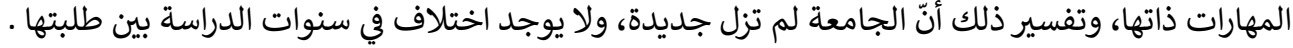

الخلاصة:

ولمّا عرضنا نتائج الدّراسة بشكل واضح، فقد أصبح إعادتها ضريًا من العبث والتكرار، لذا سألخصها على النحو الآتي:

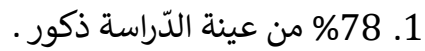

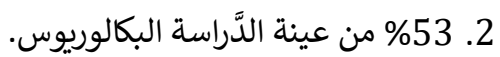

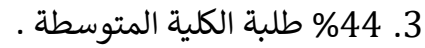

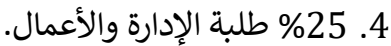

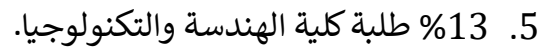

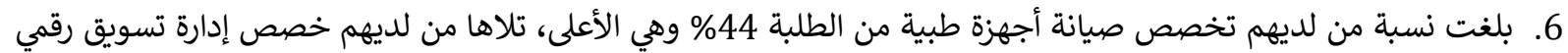

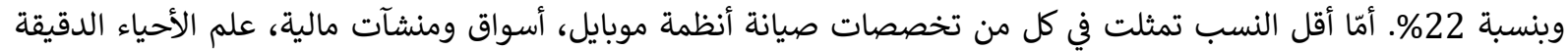

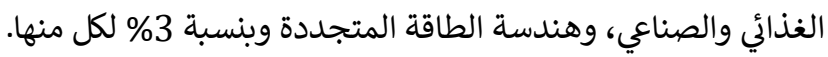
7. جاءت درجة الأثثر لمهارات التعلّم الأكثر استخداماً في العملية التعليمية لدى طلبة جامعة الزيتونة كبيرة للدرجة الكليّة لجميع

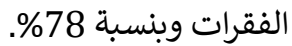

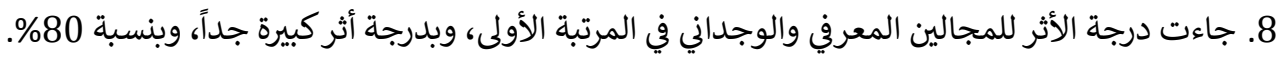

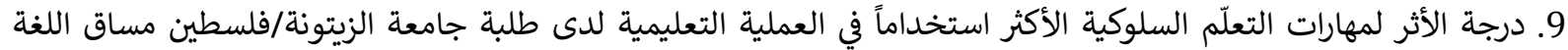

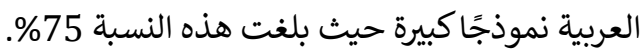

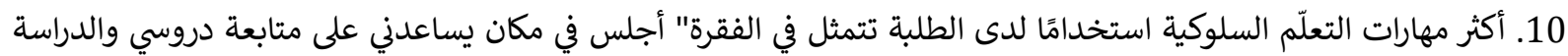

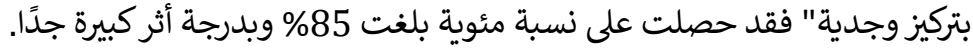

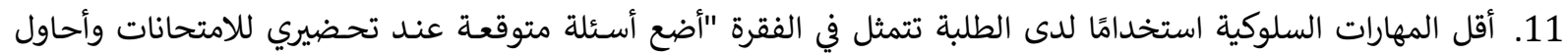

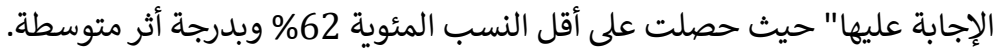
12. درجة الأثر كانت لمهارات التعلّم المعرفية الأكثر استخداماً في العملية التعليمية لدى طلبة كبيرة جداً بحيث بلغت هذه النسبة

13. أعلى نسبة مئوية لمتوسط الاستجابة للمهارات المعرفية حصلت عليه الفقرة التي تتحدث عن "أفهم الأفكار الأساسية بدل

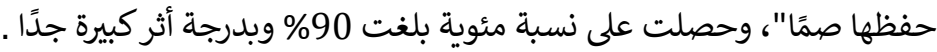

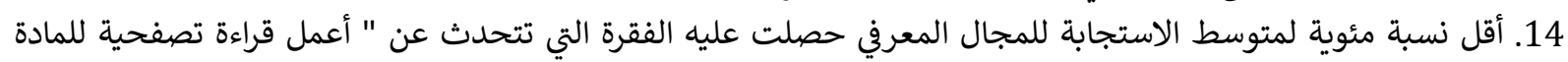

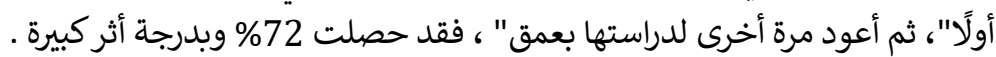

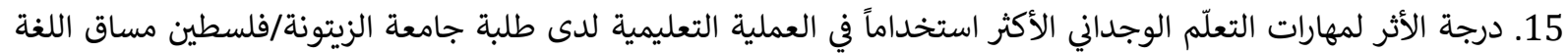

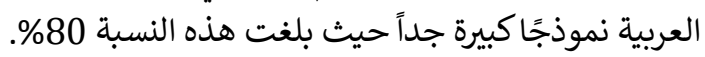

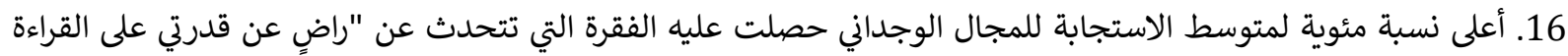

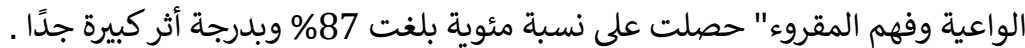

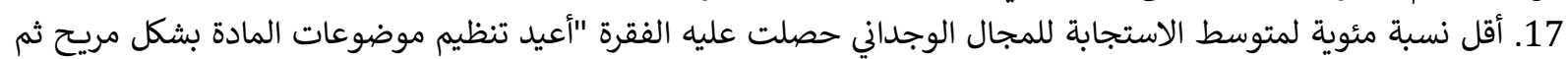

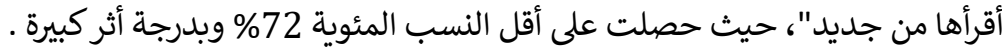

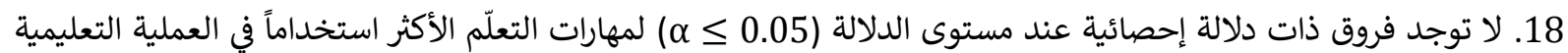
لدى طلبة جامعة الزيتونة/فلسطين مساق اللغة العربية نموذجًا تبعًا لمتغير الجنس والمرحلة الماتلة الدراسية والكلية والتخصص. 
II. International Congress of Humanities and Educational Research (IJHER Congress 2)

المصادر والمراجع

جمل محمد (2005): العمليات الذهنية ومهارات التفكير،ط2، الإمارات العربية_دار الكتاب الجامعي.

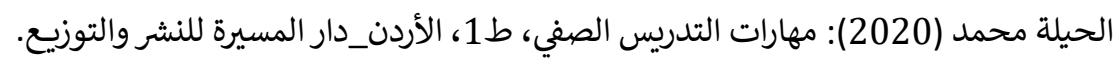

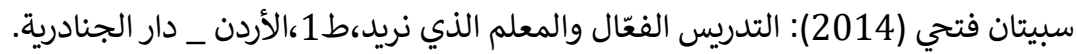
عطية محسن (2008): الاستراتيجيات الحديثة في التدريس الفعّال، عمان _دار صفاء لأنداء للنشر والتوزيع.

المواقع الإلكترونية

جامعة الزيتونة للعلوم والتكنولوجيا في سلفيتZUST 
ملحق (1)

مهارات التعلّم الأكثر استخدامًا في العملية التعليمية لدى طلبة جامعة الزيتونة/فلسطين مساق اللغة العربية نموذجًا عزيزي الطالب/ عزيزتي الطالبة

السلام عليكم ورحمة الله وبركاته؛ وبعد:

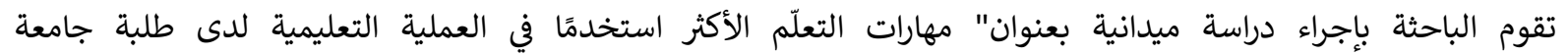

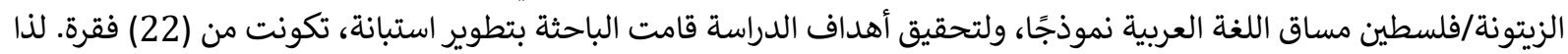

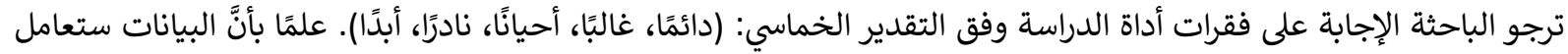
بسرية تامة، ولأغراض البحث العلمي فقط.

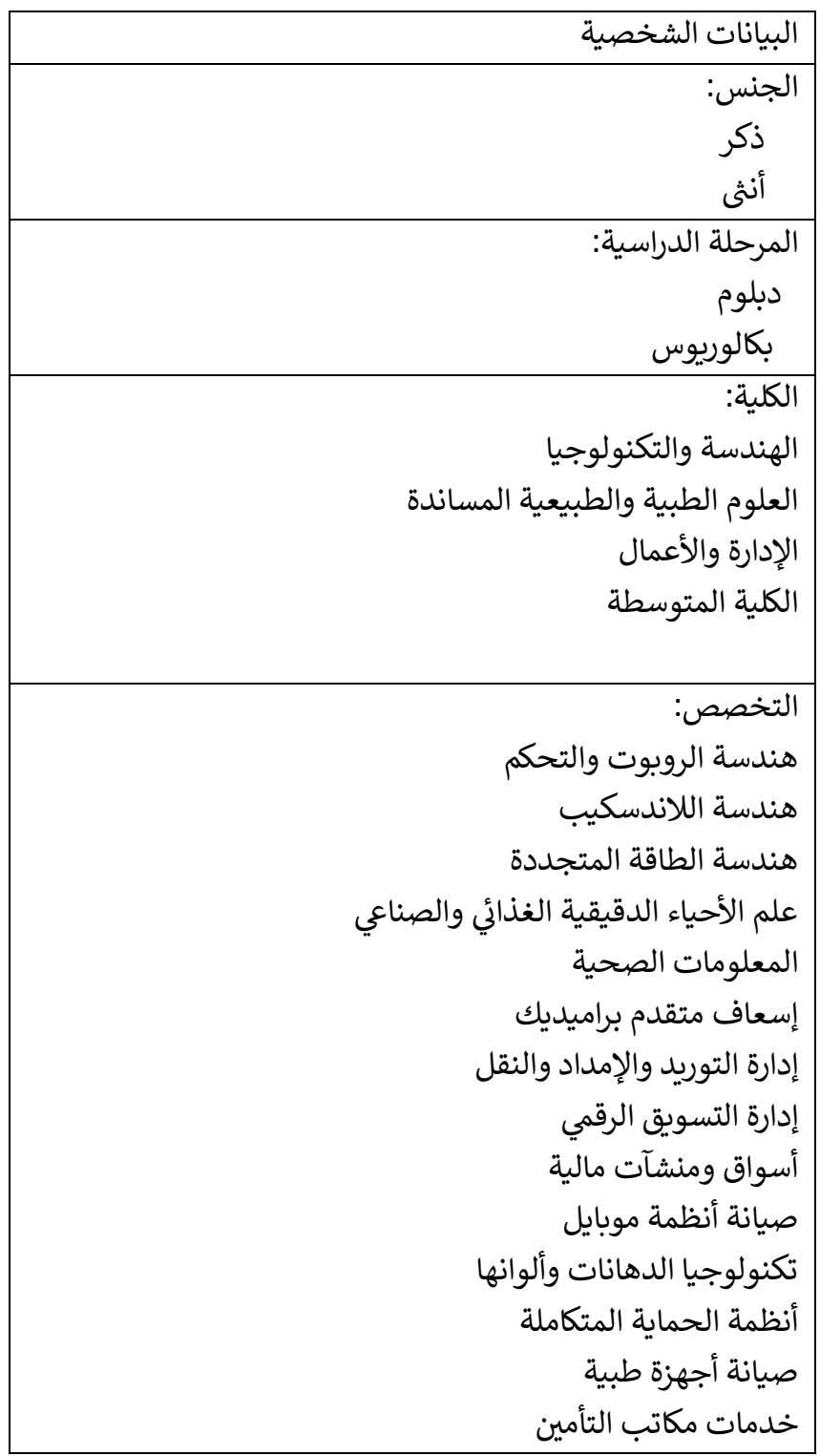


II. International Congress of Humanities and Educational Research (IJHER Congress 2)

\begin{tabular}{|c|c|c|c|c|c|c|}
\hline أبدًا & نادرًا & 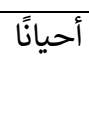 & غالبًا & دائمًا & اسم الفقرة & الفقرة - مقر \\
\hline & & & & & أولاً: المجال السلوكي & \\
\hline & & & & & أضع إشارات أو عناوين على الأجزاء & -1 \\
\hline & & & & & من الضع خطوطًا تحت الأجزاء المهمة & -2 \\
\hline & & & & & 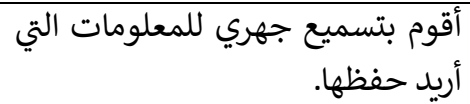 & -3 \\
\hline & & & & & للامتحانات وأحسئلة متوقعـة عند الإجابة عليها . & -4 \\
\hline & & & & & 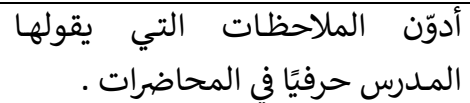 & -5 \\
\hline & & & & & عمليًا؛ قراءة وكتابة ومحادثة اللغواتية الدرسها & -6 \\
\hline & & & & & دروسي والدراسة بتركيز وجدانية. & -7 \\
\hline & & & & & المحاضظ على الحضور الدائم في & -8 \\
\hline & & & & & ثانيًا: المجال المعرفي & \\
\hline & & & & & حفظها في ذهني للمعلومات. المعلومات التي أريد & -9 \\
\hline & & & & & صمًا. أفهم الأفكار الأساسية بدل حفظها & -10 \\
\hline & & & & & أعود مرة أخرى لدراءة تصفية للمادة أولًا، ثم بعمق. & -11 \\
\hline & & & & & خاصة قبل الامتحانات. الطويلة المكثفة، & -12 \\
\hline & & & & & فهمم محتويات المقرر الدراسي. & -13 \\
\hline & & & & & بدقهم المادة التي أرغب في تذكرها & -14 \\
\hline & & & & & أحاول إيجاد روابط بين أجزاء المادة. & -15 \\
\hline & & & & & ثالثًا: المجال الوجداني & \\
\hline & & & & & بلغنتي الخاصة الأفكار المهمة على دفتري & -16 \\
\hline & & & & & أوقات راحة قصيرة. & -17 \\
\hline & & & & & مريح ثم أقرأها من جديد موضوعات المادة بشكل & -18 \\
\hline & & & & & في المادة لتسهيل حأبوّب المعلومات الموجودة & -19 \\
\hline & & & & & لتحسينها & -20 \\
\hline & & & & & أعزز نفسي وأحفزها لمواجهة & -21 \\
\hline
\end{tabular}


Full Text Book of IJHER Congress 2

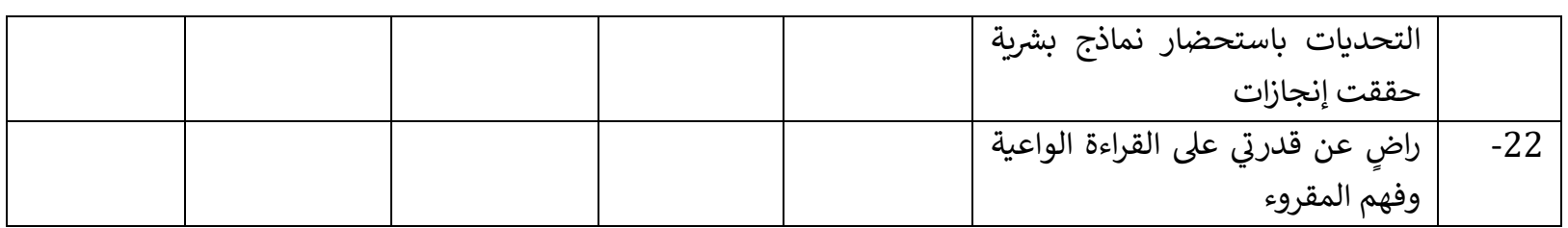


THE REALITY OF EDUCATIONAL SCIENTIFIC RESEARCH IN REGIONAL CENTERS OF EDUCATION AND TRAINING PROFESSIONS AND THE MECHANISMS FOR ITS DEVELOPMENT

Youssef GUEROUAOUI 


\title{
THE REALITY OF EDUCATIONAL SCIENTIFIC RESEARCH IN REGIONAL CENTERS OF EDUCATION AND TRAINING PROFESSIONS AND THE MECHANISMS FOR ITS DEVELOPMENT
}

\author{
Youssef GUEROUAOUI ${ }^{1}$
}

\begin{abstract}
:
Educational research is only one of the areas of scientific research, or a branch of scientific research, as a careful, organized and critical attempt to address educational problems and issues of a practical nature, starting from monitoring and identifying the problem and subjecting it to the test of meditation, reflection and diagnosis in order to reach possible and appropriate solutions to it, as educational research is a mechanism of developing the work of teachers and raising the quality of their composition and improving their classroom practices, in addition to contributing to the drawing of educational policy, and providing information And the data needed for educational decision-making...

If the educational research has all these and other advantages, we find that the ministry of the guardian of the national education sector in the Kingdom of Morocco did not give him the status that befits him, and the result was the emergence of an educational crisis in our country, where our educational system occupied very low ranks as will come later, which made king Mohammed VI Nasrallah warn of the seriousness of the crisis in his historic speech 20 August 2013.This was recently revealed by the Development Model Committee in April 2021.

The Ministry has recently been alerted to the importance of educational scientific research in addressing this educational crisis and has issued some regulations and legislation to encourage it.

Despite the state's efforts in this area, the meditator of the educational research situation in the various research centers in our country, as in other Arab countries, notes that there are many obstacles and difficulties in it and limit its performance of its expected role.

From this point of view, this modest study came to shed more light on the reality of educational research in the regional centers of the professions of education and training, focusing on the most important difficulties facing it, hoping to find appropriate solutions to this situation in order to build a new Moroccan school that responds to the expectations of society and looks forward to its development prospects. From God, we derive help, conciliation and payment.

Key words: Educational Research, Scientific Research, Regional Centers For Education And Training Professions.
\end{abstract}

http://dx.doi.org/10.47832/ijhercongress2-2

${ }^{1}$ Regional Center for Education and Training For Fez/Meknes, Morocco, Youssef gr64@ live.fr, https://orcid.org/0000-0001$\underline{6002-6251}$ 
II. International Congress of Humanities and Educational Research (IJHER Congress 2)

واقع البحث العلمي التربوي بالمراكز الجهوية لمهن التربية والتكوين وآليات تطويره

يوسف كرواوي 2

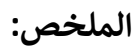

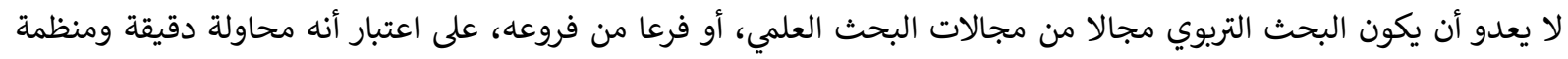

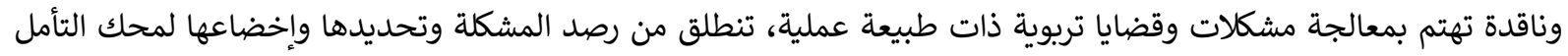

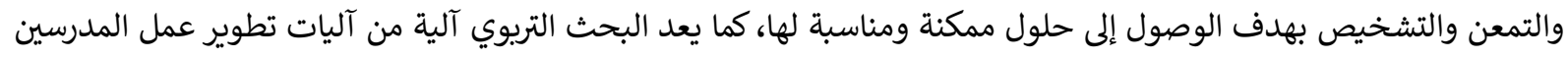

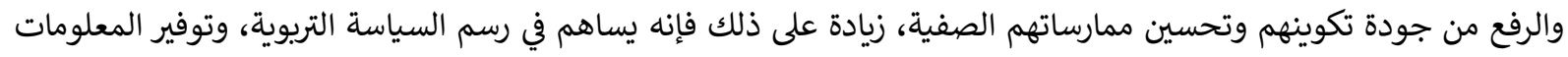

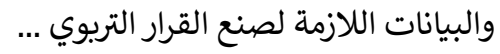

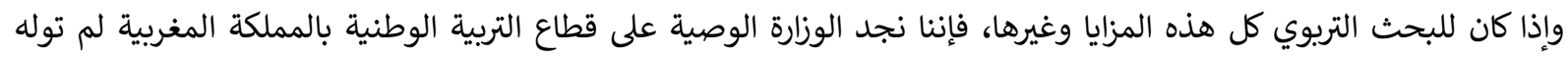

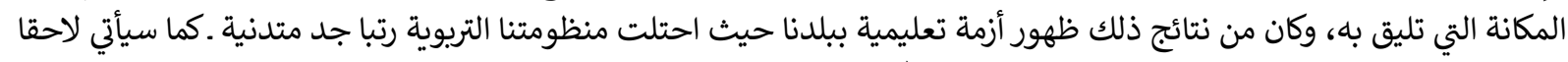

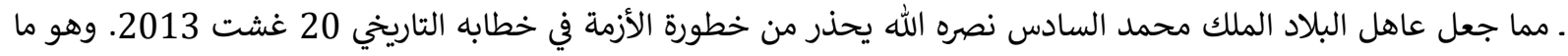

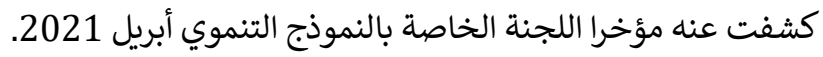
ولقد تنبهت الوزارة مؤخرا لأهمية البحث العلمي التربيوي في معالجة هذه الأزئة التربة التربوية فأصدرت بعض الأنظمة والتشريعات اللازمة لتشجيعه .

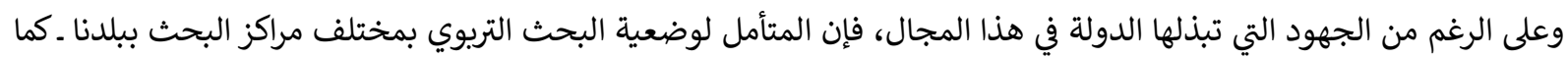

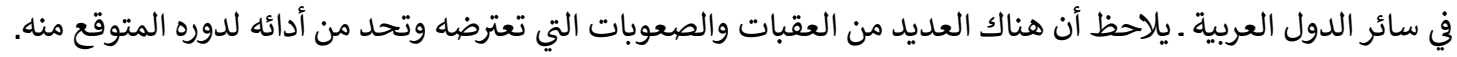

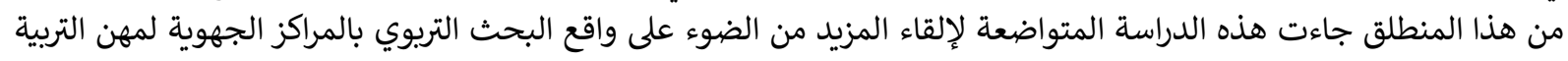

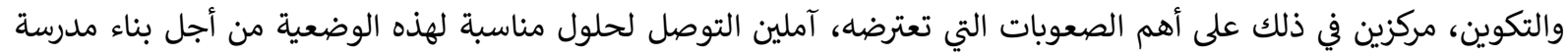

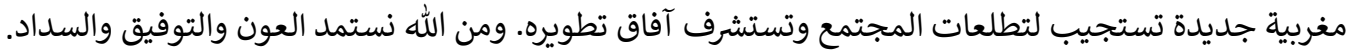
الكلمات المفتاحية: البحث التربوي، البحث العلمي، المراكز الجهوية لمهن التربية والتكونئ ونكوين. 
يعد البحث التربوي آلية من آليات تطوير عمل المدرسين والمدرسات والرفع من تكوينهم وتحسين ممارساتهم الصفية،

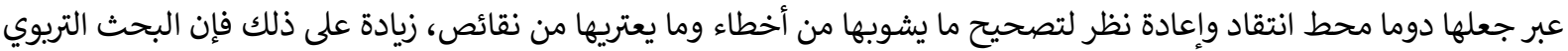

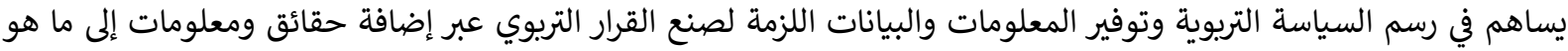
متراكم في حقل المعرفة باستخدام الطريقة العلمية في التفكير، تمهيدا لعمليات التغيير والتجديد التريوي وإثراء المعرفة وتوظيفها وليفا التوظيف السليم لحل المشكلات.

وبالتالي لم يعد البحث التربوي رفاهية أكاديمية تمارسه مجموعة من الباحثين "القابعين في أبراج عاجية" إذ يؤكد معظم التئم

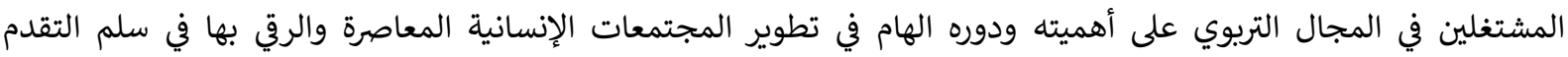
الحضاري.

وإذا كان للبحث التربوي كل هذه المزايا وغيرها، فإننا نجد الوزارة الوصية على قطاع التربية الوطنية لم توله المكانة التي تليق

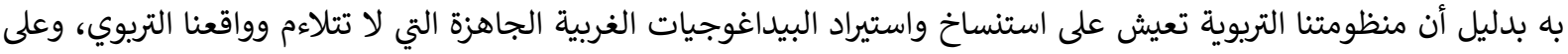

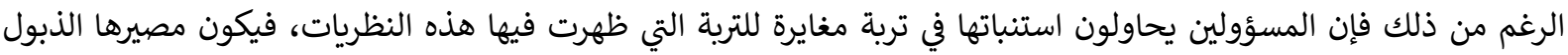

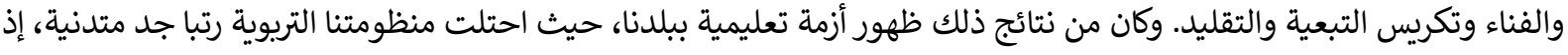

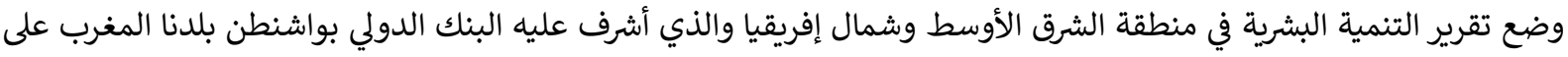

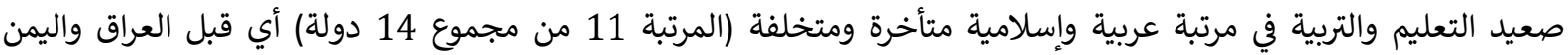

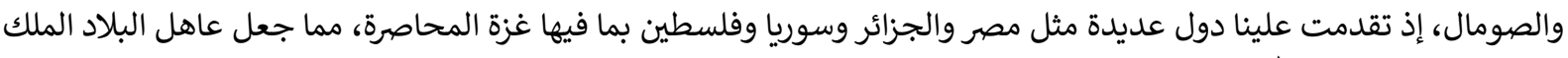

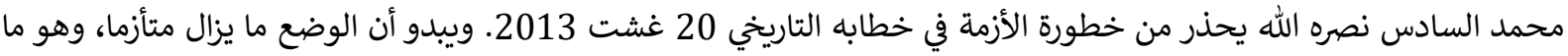

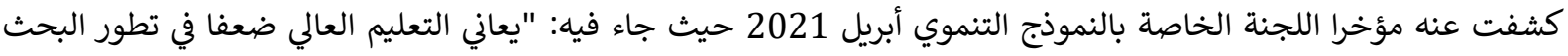
العلمي وانفتاحه المحدود على محيطه الاجتماعي والمهني".

وإذا كان من المقبول الاستفادة من البحوث العلمية الأجنبية ونتائجها في مجال العلوم التجريبية، فإنه من غير المقبول

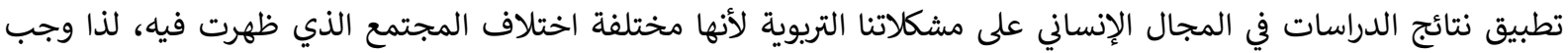
التفكير في مقارية المشكل بما يتماشى وخصوصية ثقافتنا المغربية والإسلامية.

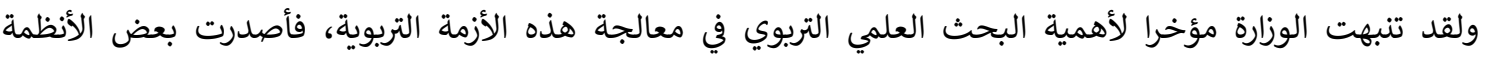

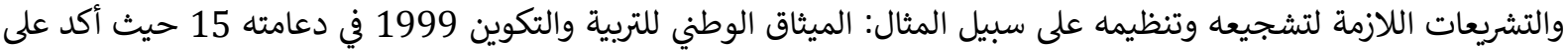

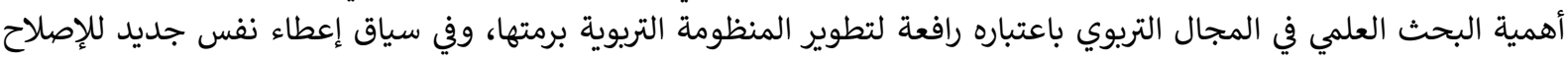

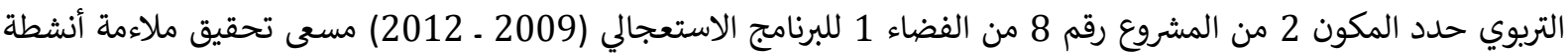

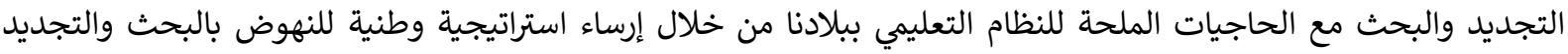

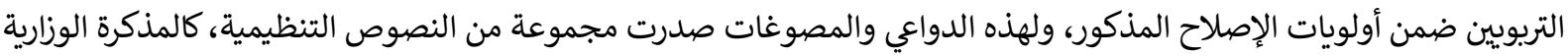

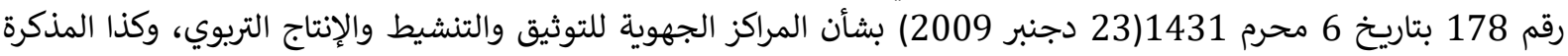

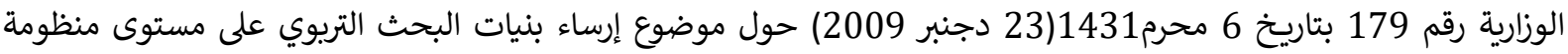

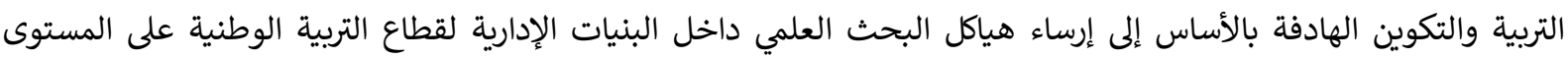

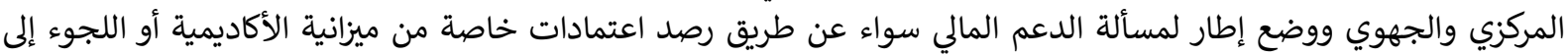

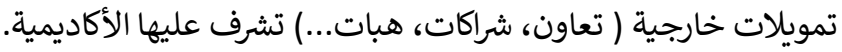

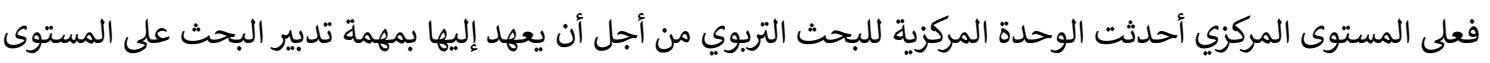

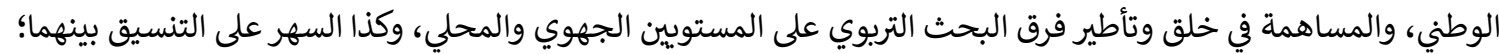

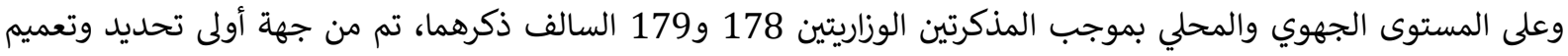

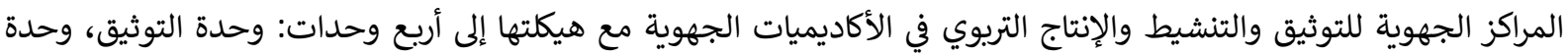

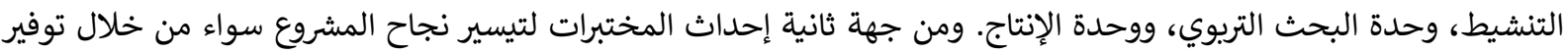

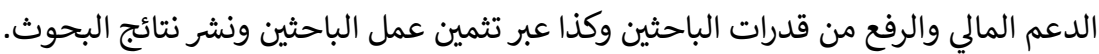

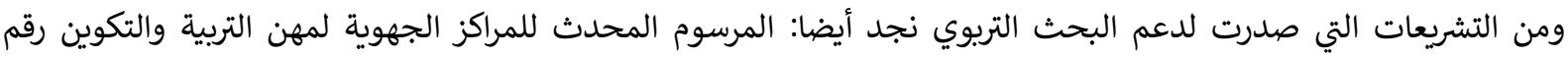

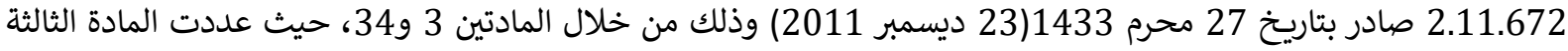

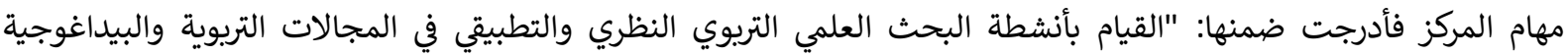

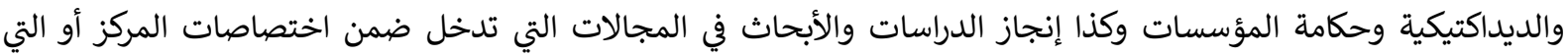
يتطلبها التكوين ..." وكذا الرؤية الاستراتيجية 2015 ـ 2030 من خلال الرافعة الرابعة عشرة والتي جاء فيها: " ... وكذا النهوض 
بكافة مجالات البحث والابتكار، بما فيها مجالات العلوم التريوية والترجمة خدمة لتطور المعرفة والتنمية البشرية...". وأخيرا القانون

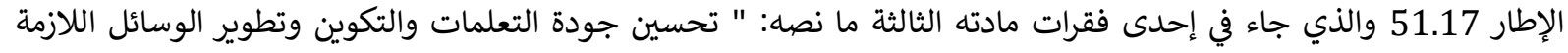

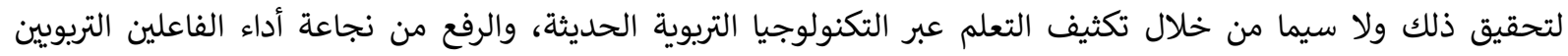

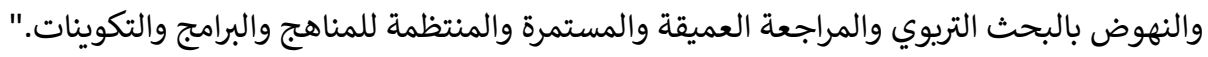

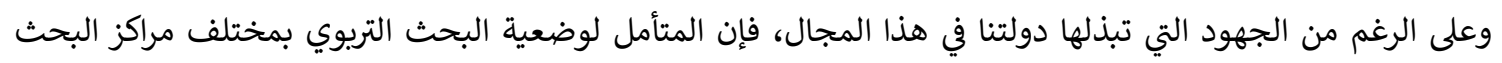

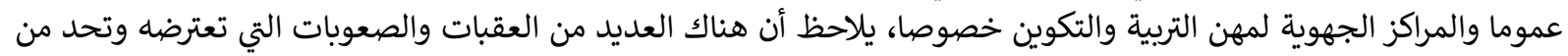
أدائه لدوره المتوقع منه.

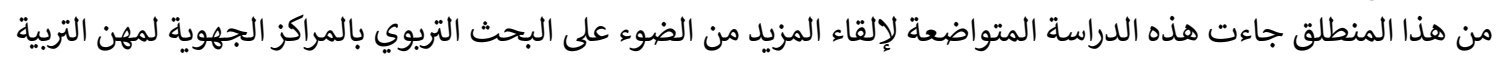

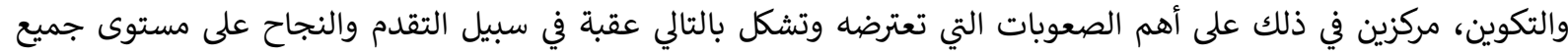

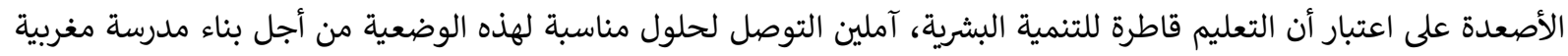

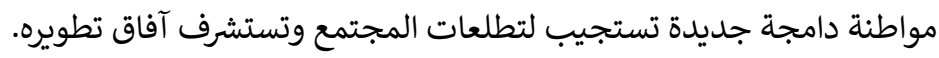

وتبعا لذلك سنتناول هذه الدراسة من خلال المطالب الثلاثة التالية: المطلب الأول: خصصناه لتحديد المفاهيم الواردة في

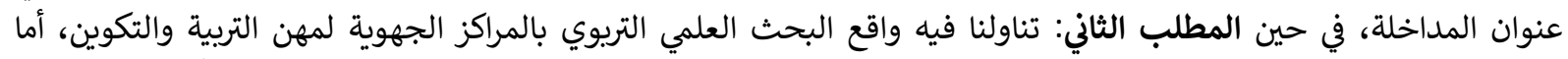

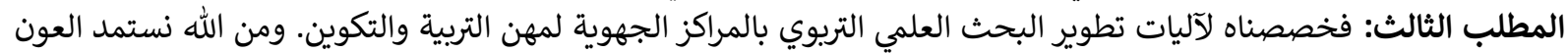

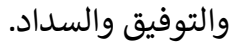


سنحاول من خلال هذا المطلب تحديد المفاهيم التالية: البحث التربوي، البحث العلمي، المراكز الجهوية لمهن التربية

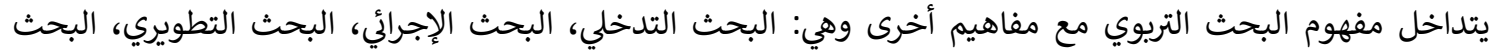

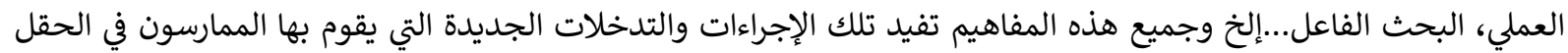

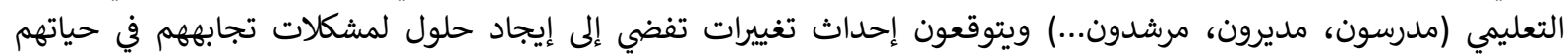

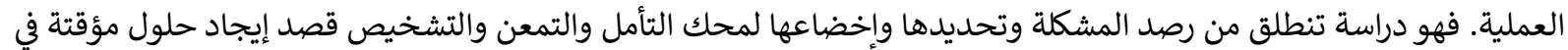

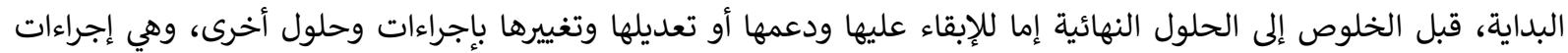

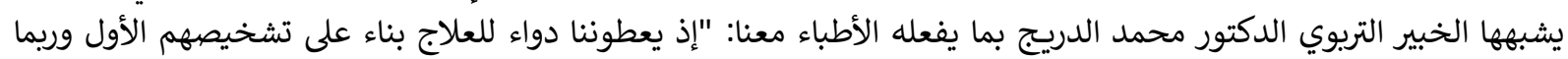

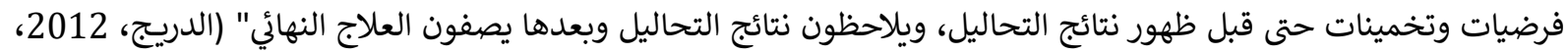
موقع منتديات الأستاذ).

كما عرفت البحوث التربوية بكونها تلك البحوث التي يقوم بها أطراف العملية التربوية من معلمين وإداريين ومشرفين بهدف التهاف

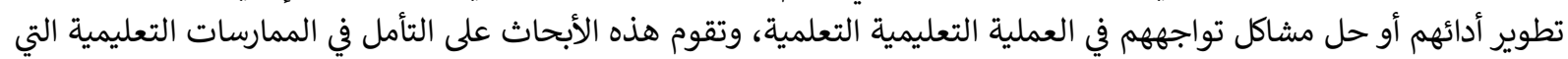

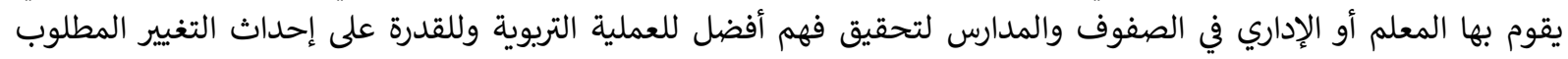

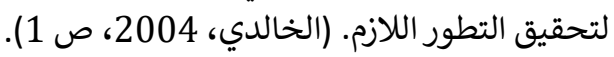

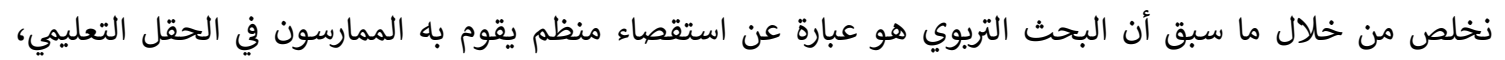

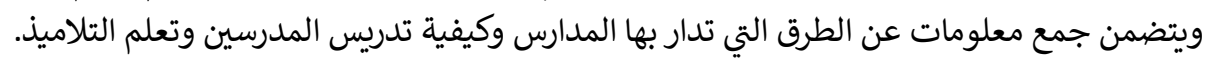

ثانيا: البحث العلمي

تختلف التعريفات الخاصة بالبحث العلمي، ويعزى ذلك لارتباطها في كثير من الأحيان مع أساليب البحث المتبعة. وتبعا

لذلك هناك العديد من التعريفات نورد بعضا منها فيما يلي:

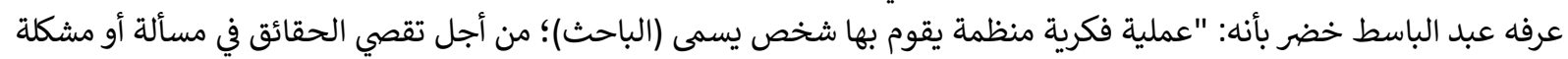

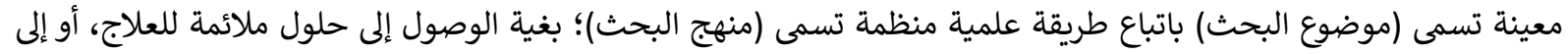

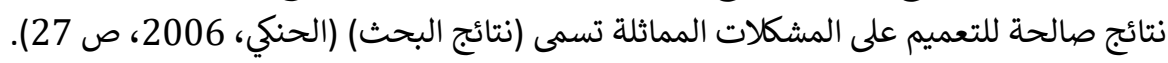

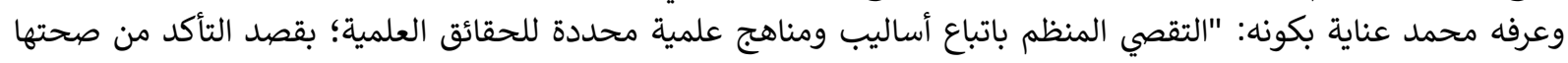

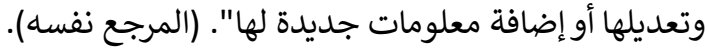

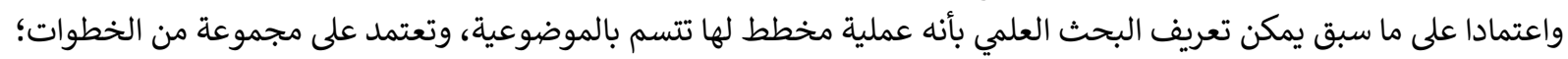
بهدف البحث في ظاهرة معينة ومعرفة الحقائق والمبادئ اللازمة لاكتشاف حلول مساعدة على على حلى حل مشكلة معلى معينة (اقتصادية،

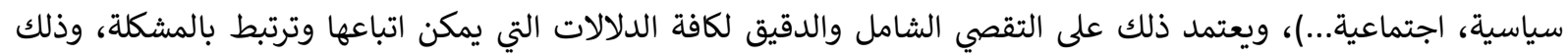
باستخدام الأساليب العلمية.

\section{ثالثا: المراكز الجهوية لمهن التربية والتكوين}

هي مؤسسات لتكوين الأطر العليا (مدرسون، أطر الإدارة التربوية، أطر الدعم الإداري والتربوي والاجتماعي، أطر المراقبة

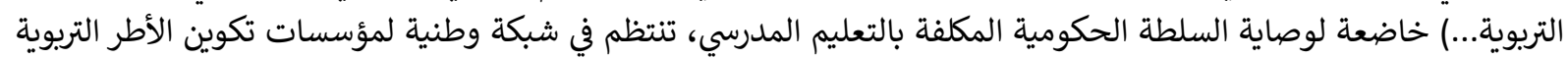

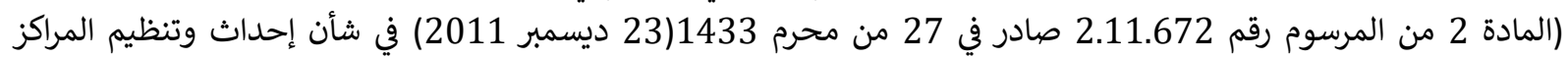

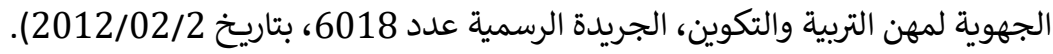

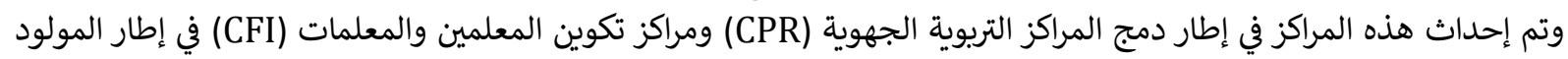
الجديد، المراكز الجهوية لمهن التربية والتكوين (CRMEF) مع انطلاقة الموسم التكويني 2012 ـ 2013. 


\section{المطلب الثاني: واقع البحث العلمي التربوي بالمراكز الجهوية لمهن التربية والتكوين}

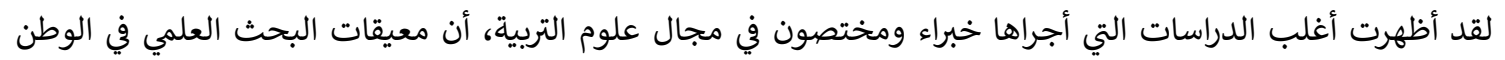

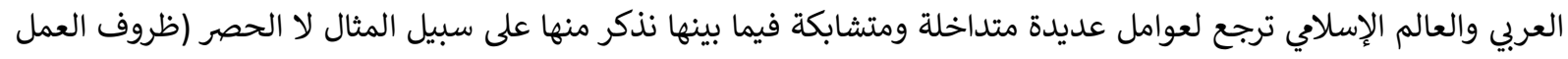

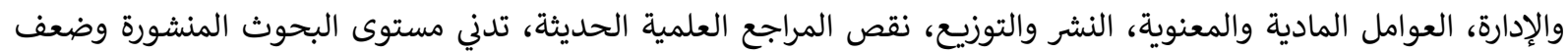

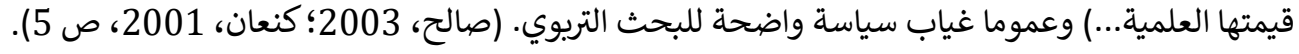

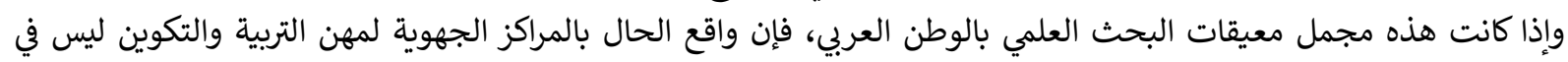
معزل ومنأى عن هذه العقبات بل تتقاسمها معه وتستزيد أحيانا.

\section{ومن أهم الصعوبات التي تواجه البحث العلمي التربوي بهذه المراكز نذكر ما يلي:}

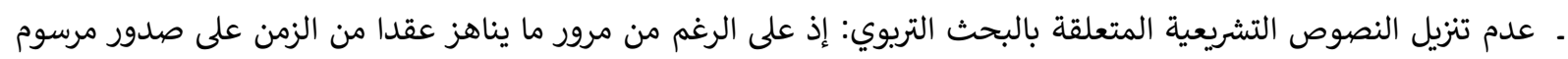

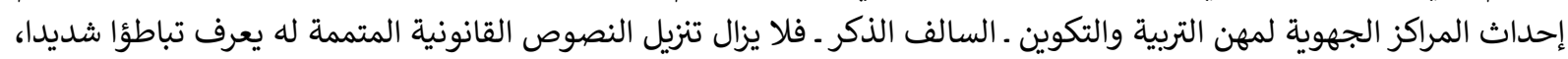

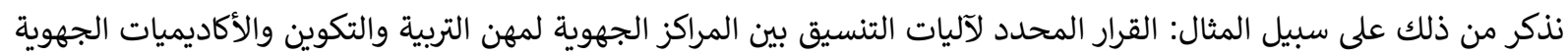

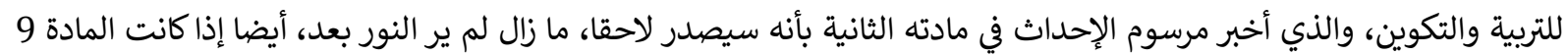

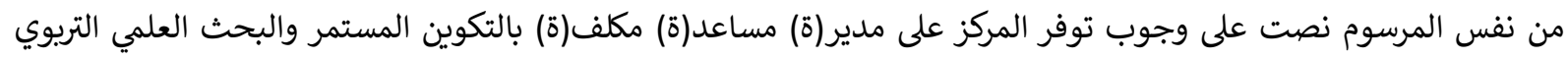

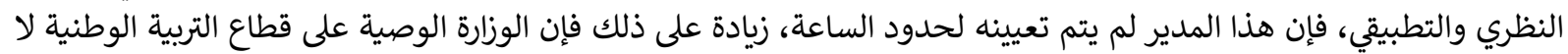

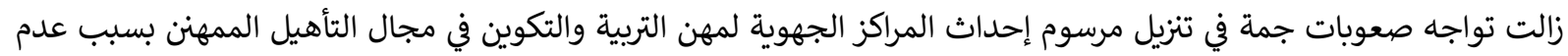

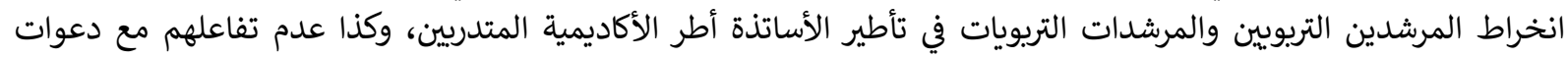

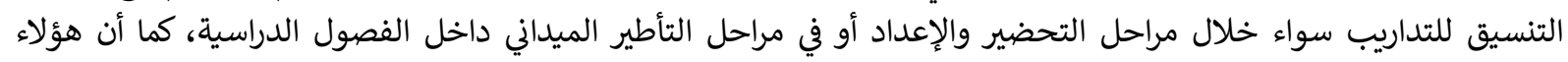

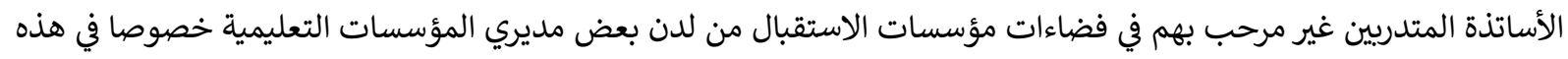

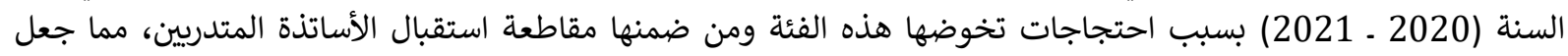

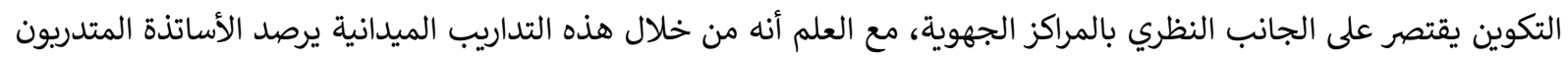

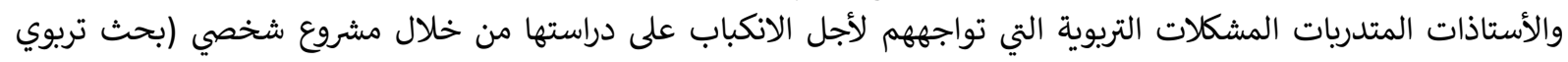
تدخلي).

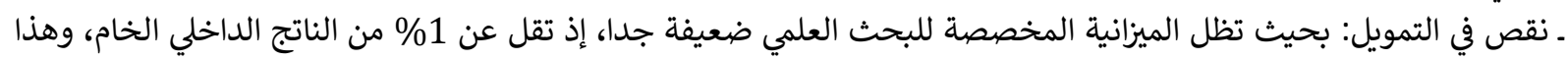

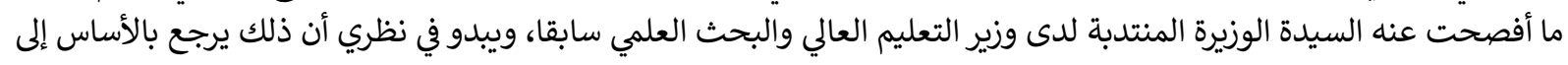

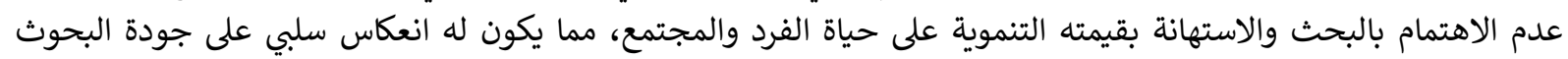

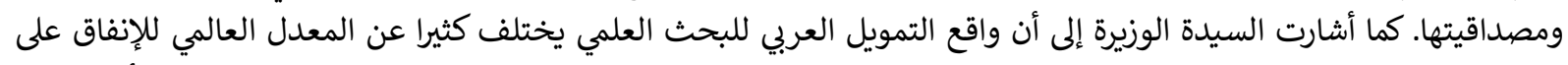

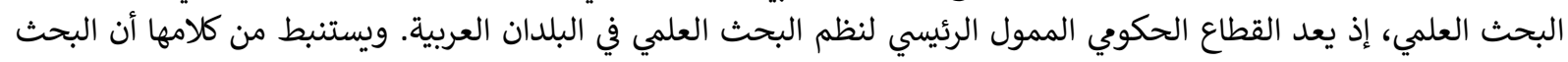

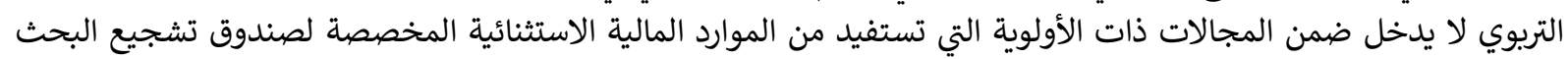

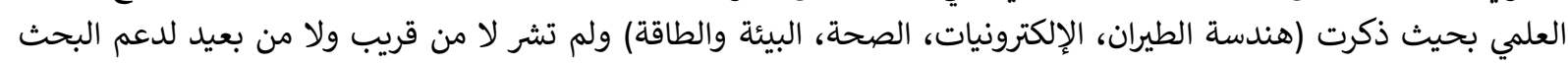

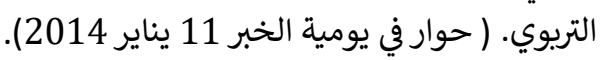

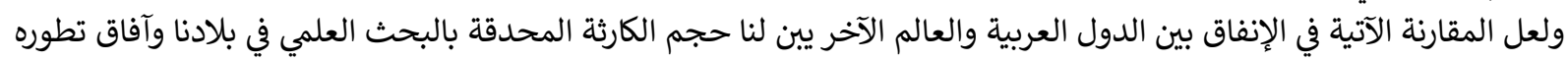

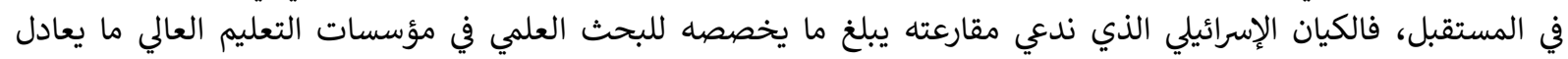

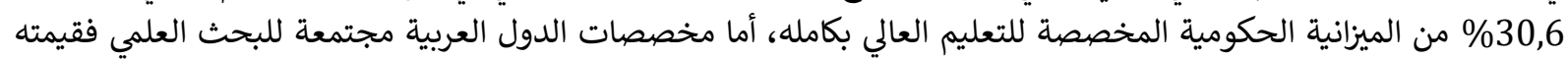

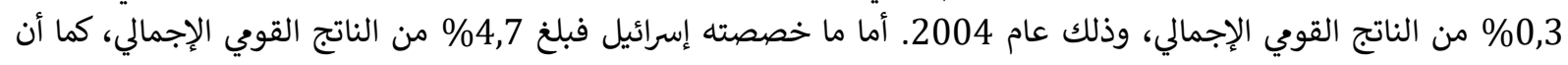

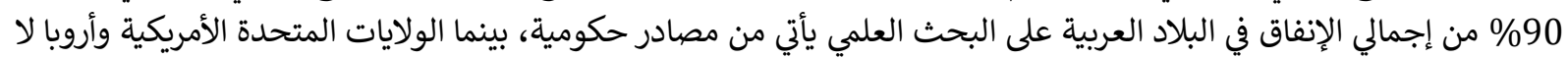

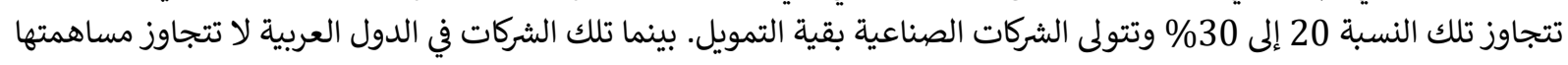

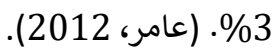

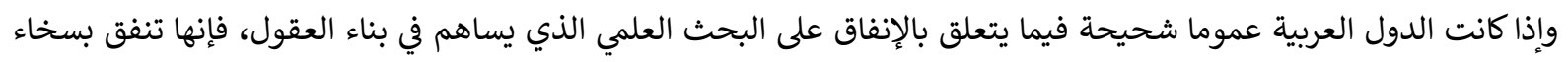

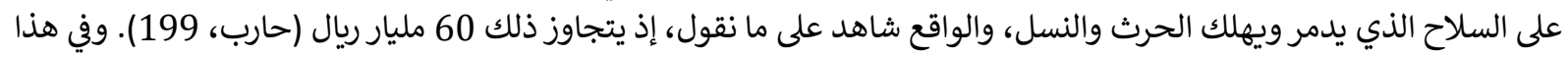

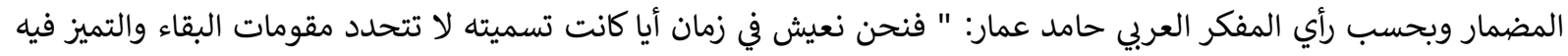

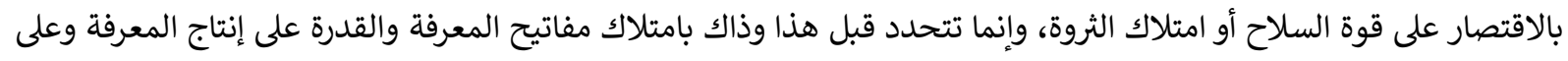

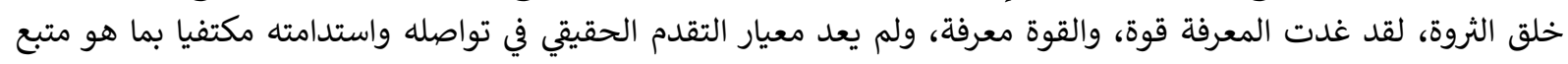

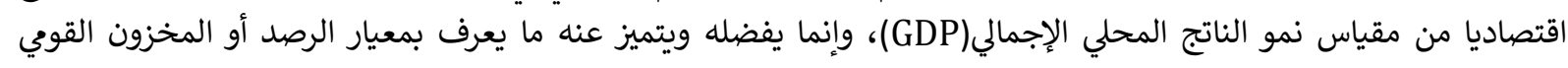

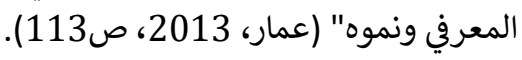




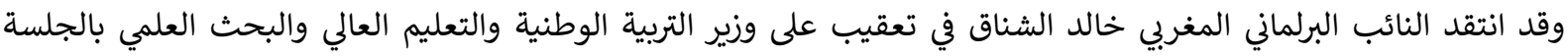

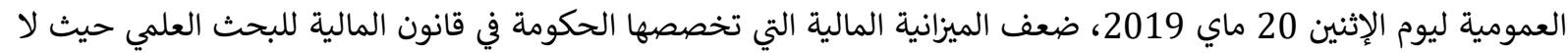

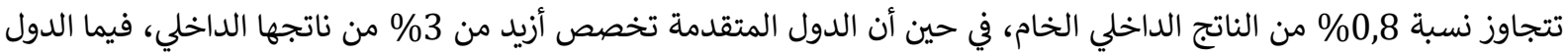

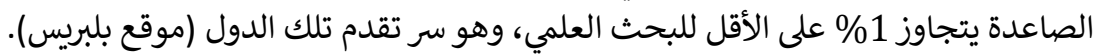

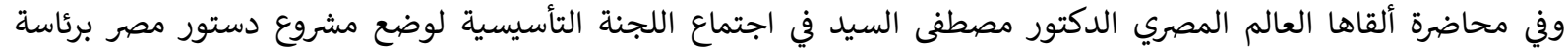

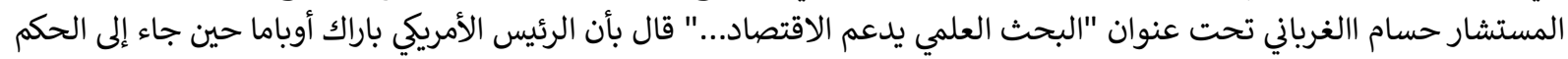

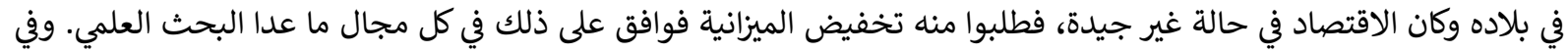

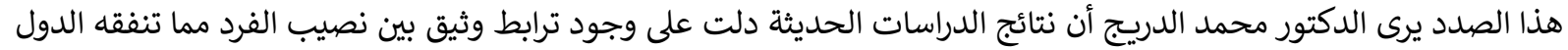

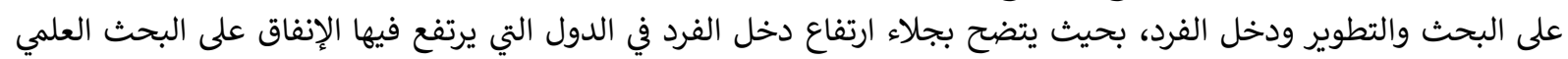

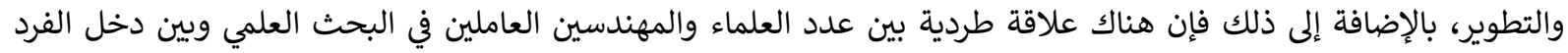

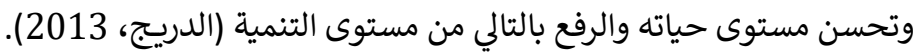

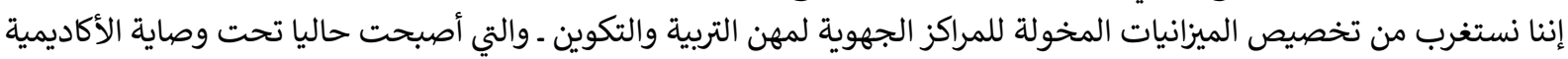

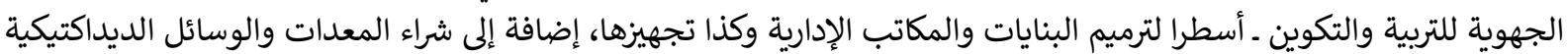

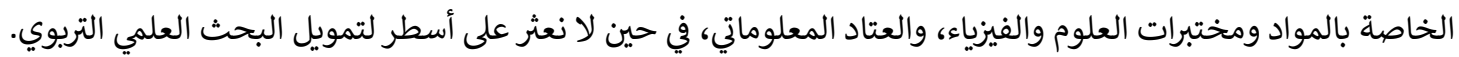

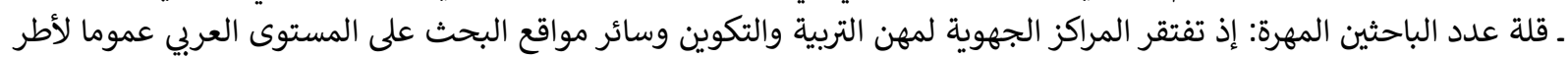

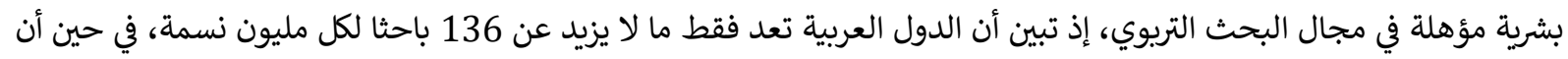

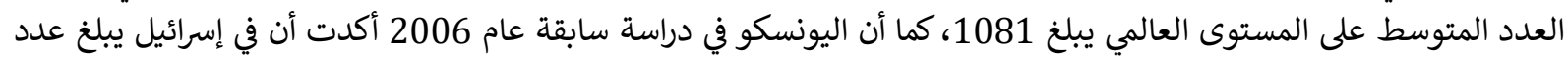

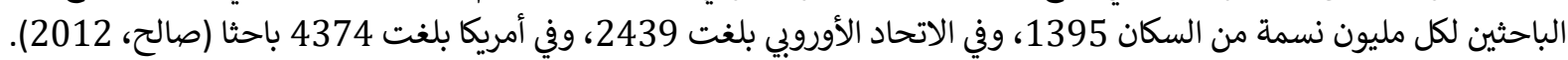

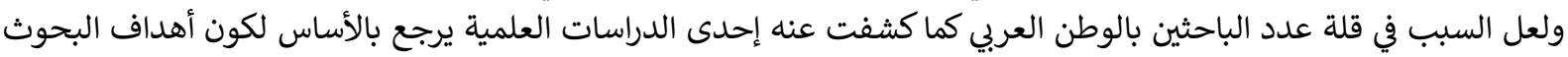

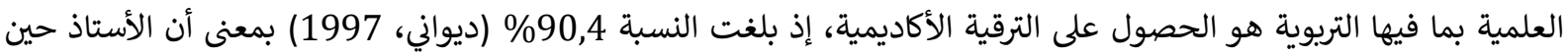

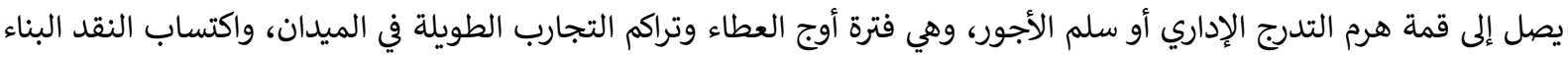

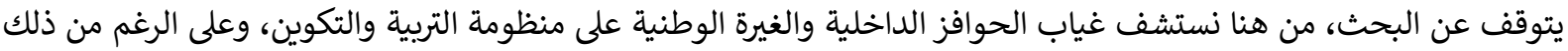

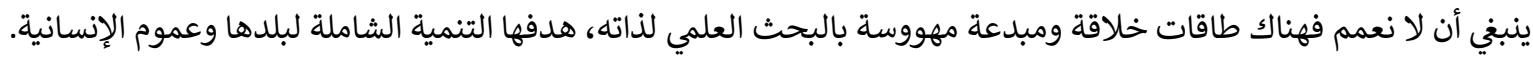

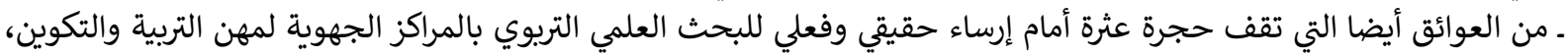

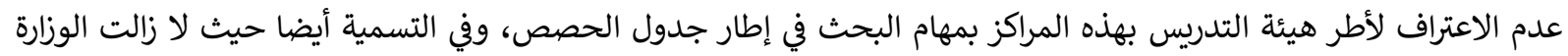

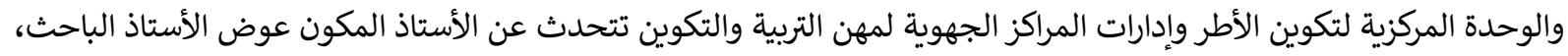

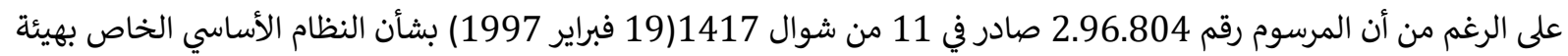
الأساتذة الباحثين بمؤسسات تكوين الأطر العليا يعتبر البحث من صميم مهام الأساتذة الباحثين بهذه المؤسسات (المادتان 3 و4 بآن

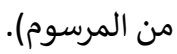

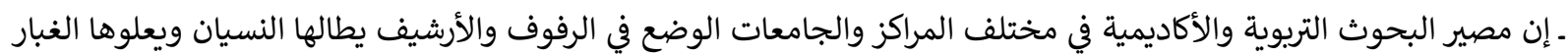

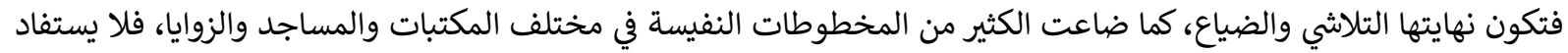

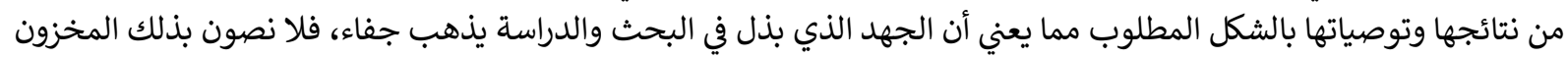
الثقافي ولا نحافظ على الذاكرة التربوية.

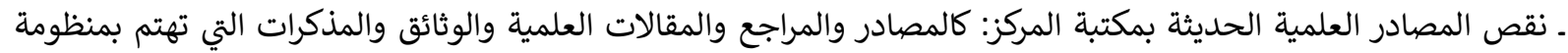

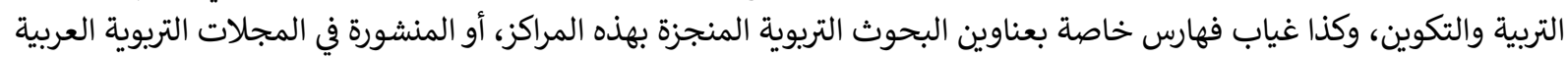

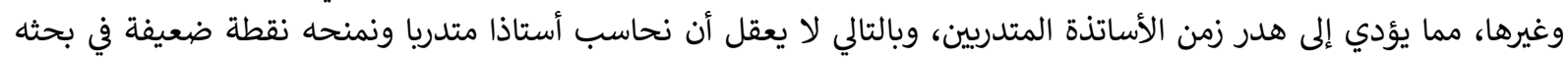

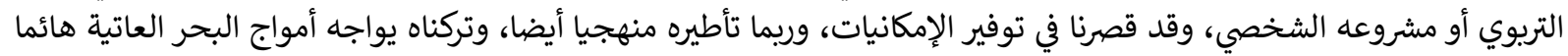

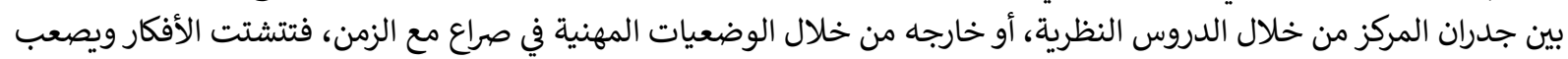

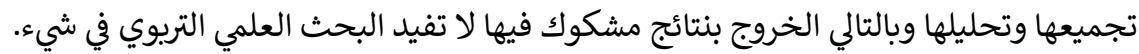

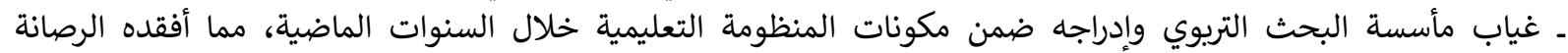

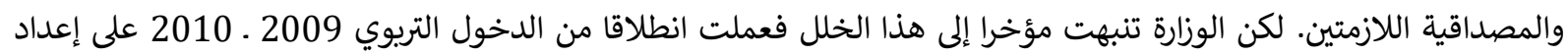

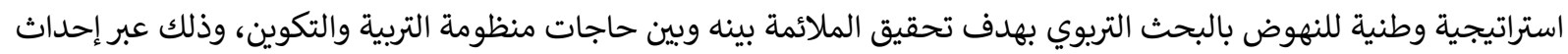

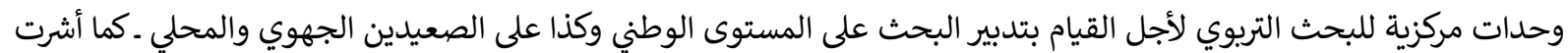

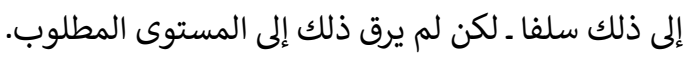

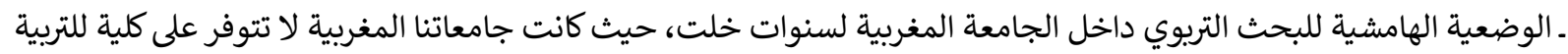

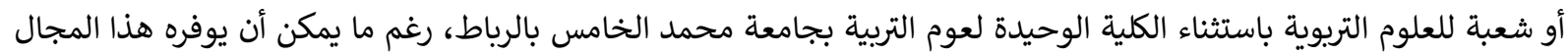




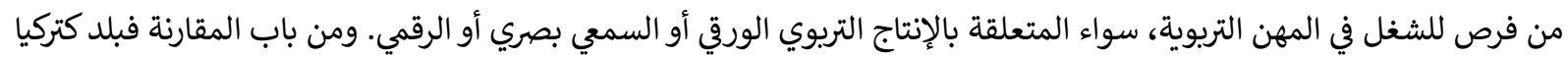

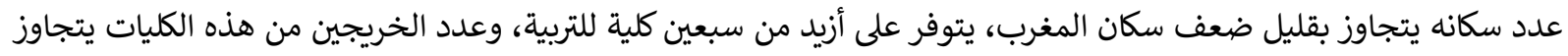

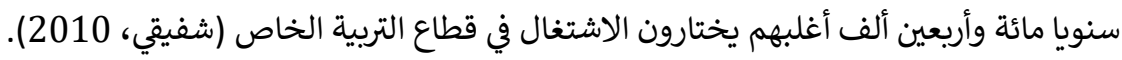

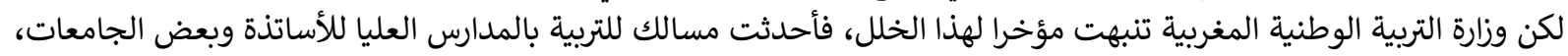

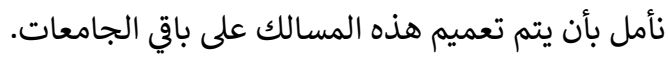

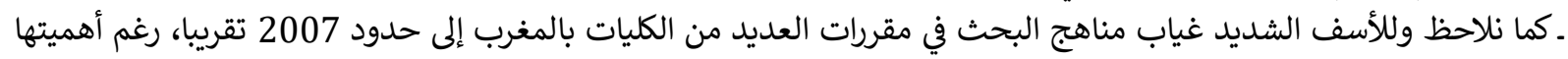

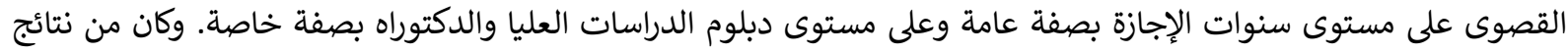

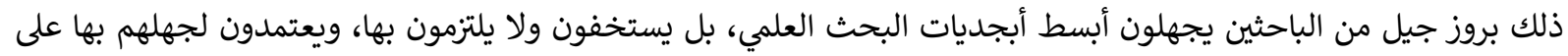

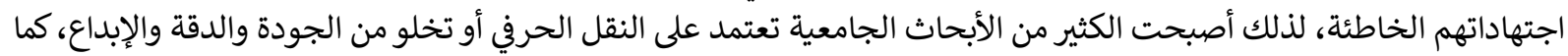

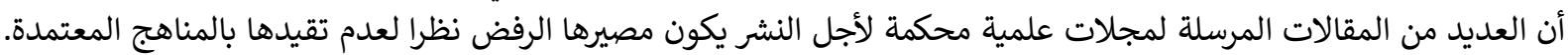

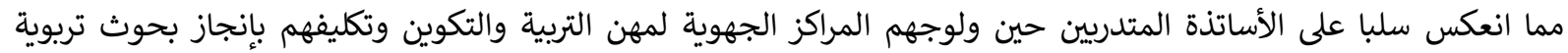

تدخلية.

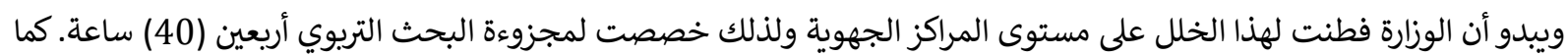

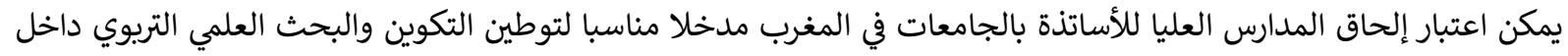

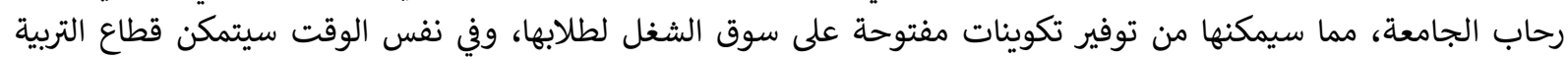

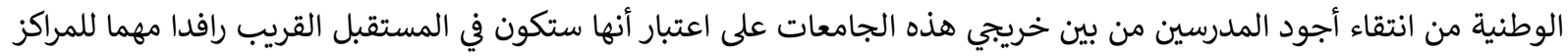

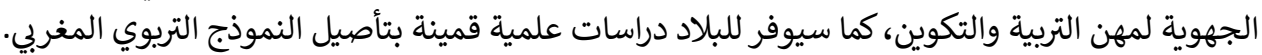

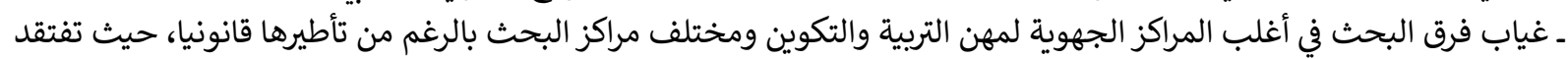

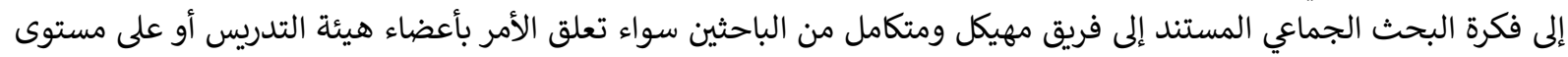

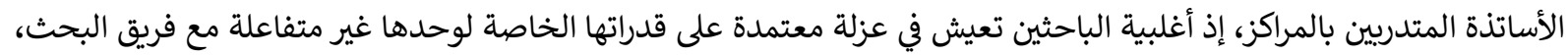

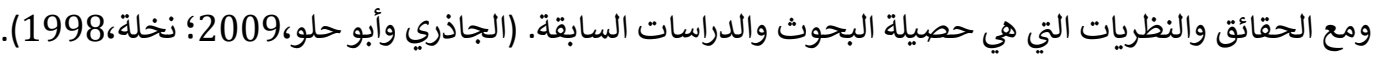

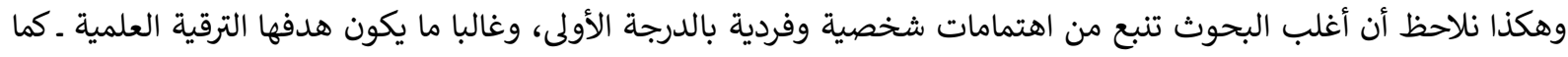

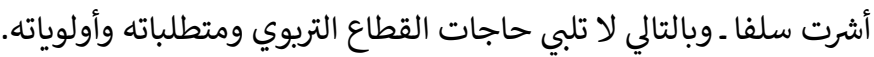

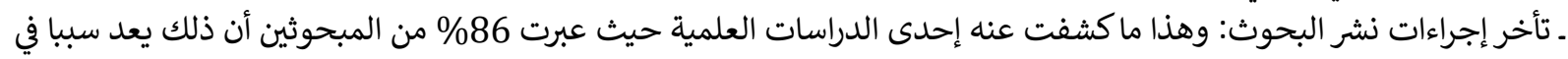

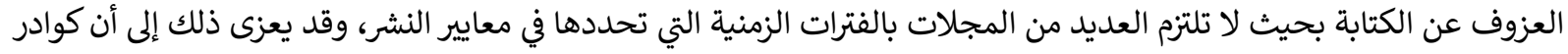

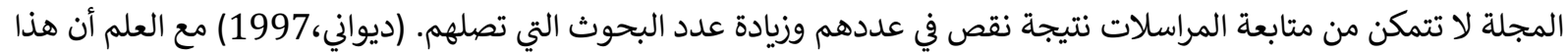

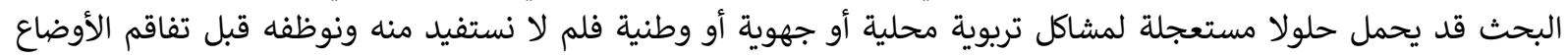
وتأزمها.

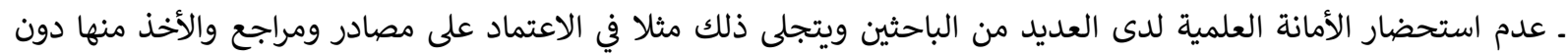

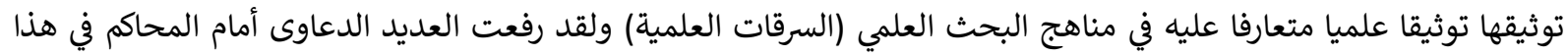

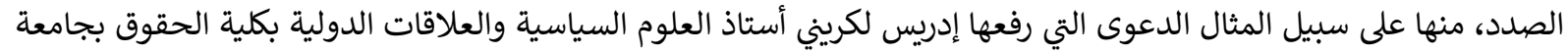

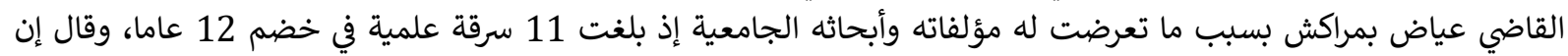

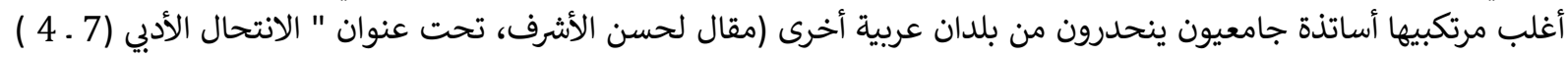

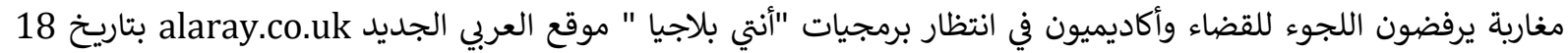

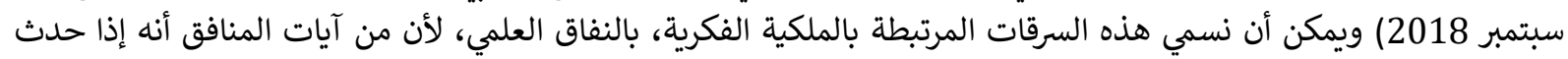

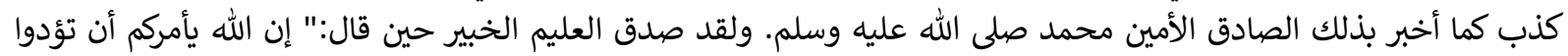

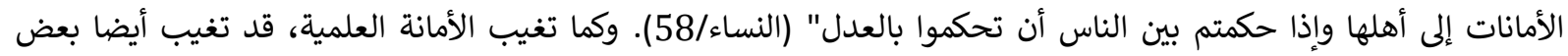

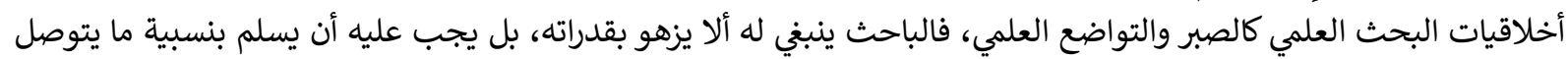

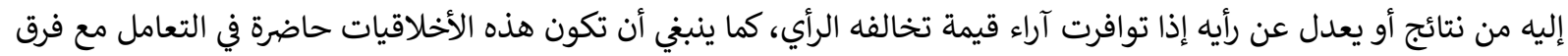

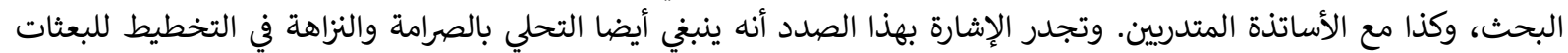

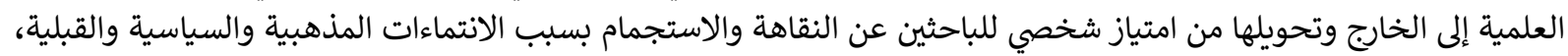

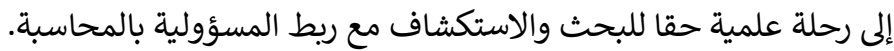
ـ هجرة الباحثين من العالم الثالث إلى الدول المتقدمة، وهذه كارثة أطلق عليها بعض العاف العلماء العاء (نزيف المخ البشري) أو"هجرة

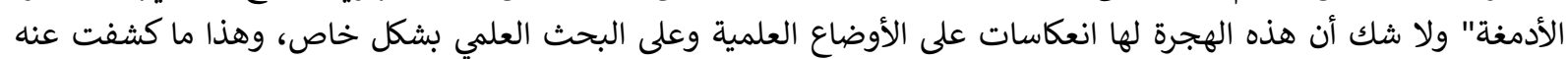

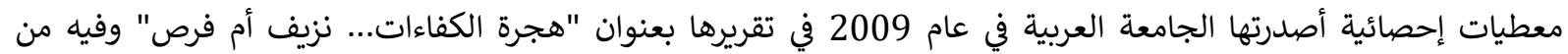

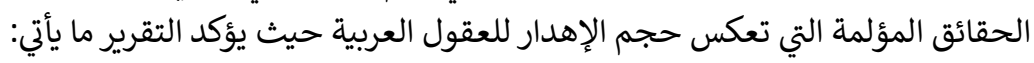




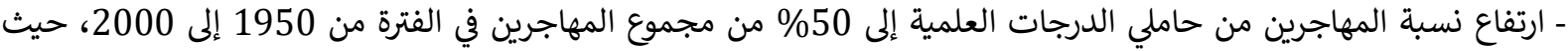

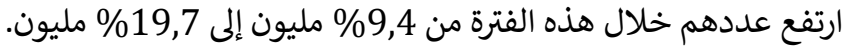

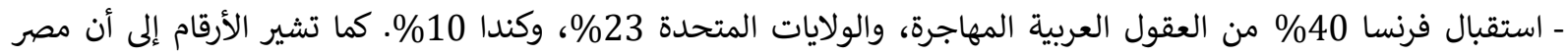

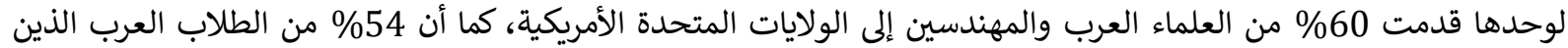

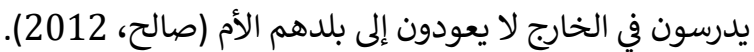

\section{ومن الصعوبات التي قد تعترض الأساتذة المتدربين بالمراكز الجهوية لمهن التربية والتكوين نذكر ما يلي:}

ـ عدم إلمام العديد منهم بمجال كتابة البحث (كتوثيق البحث بشكل دقيق، صياغة مشكلة البحث، صياغة الفرضيات البحثية،

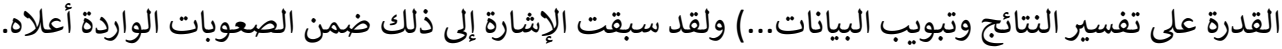

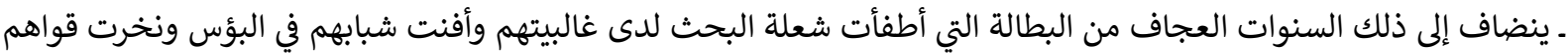

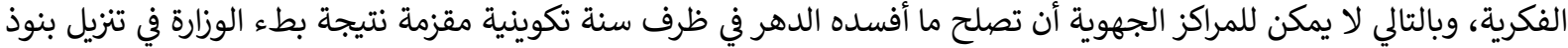

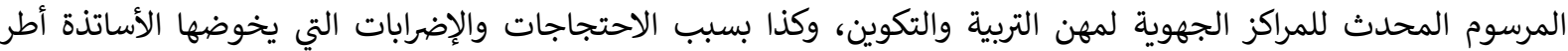

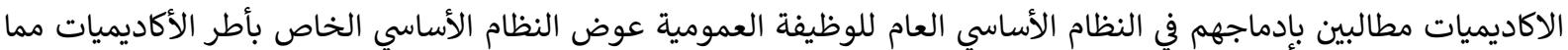

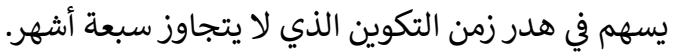

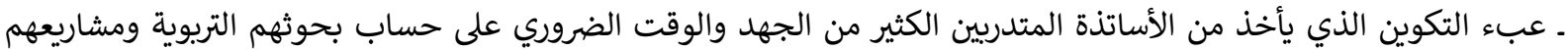

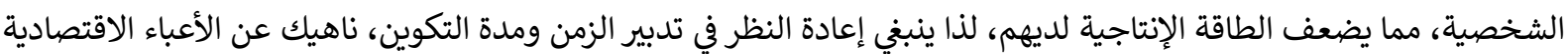

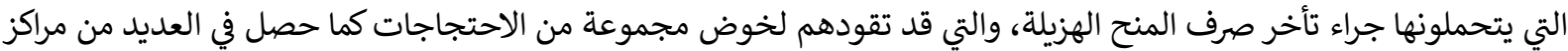

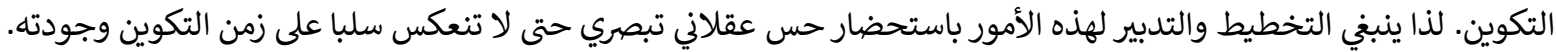

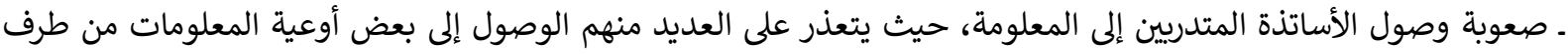

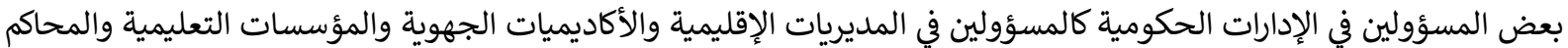

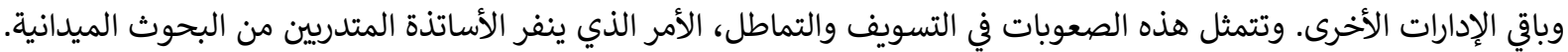

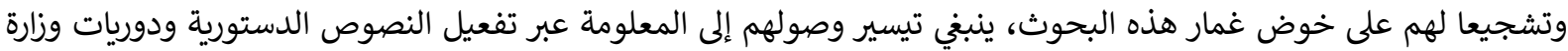

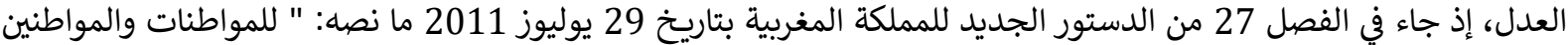

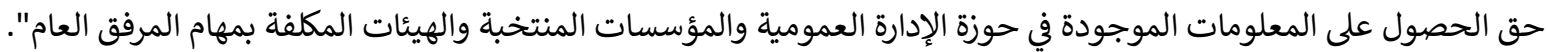

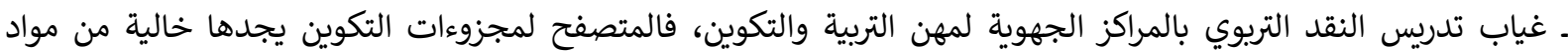

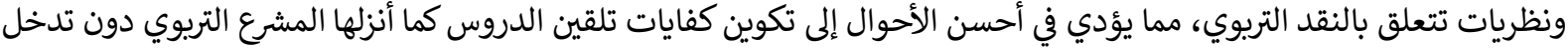

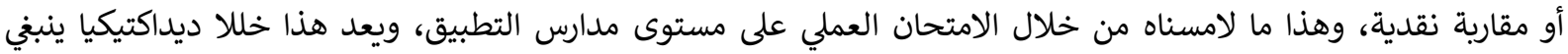

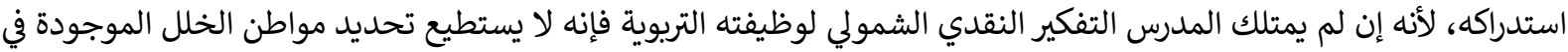

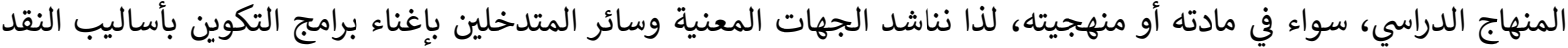

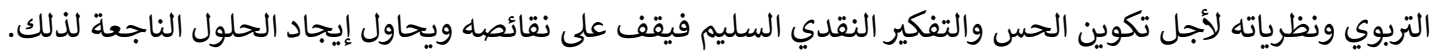

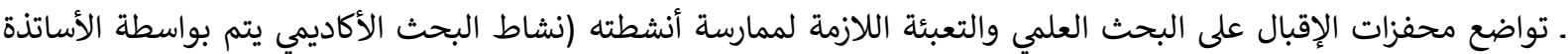

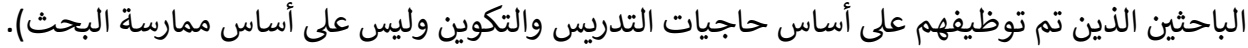

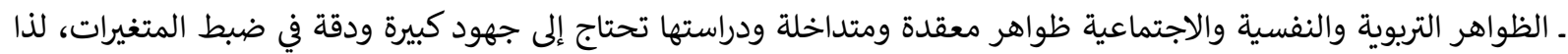

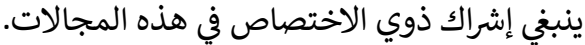

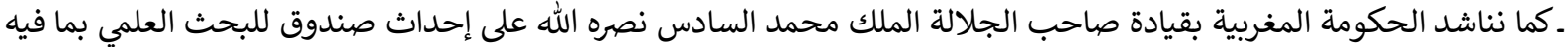

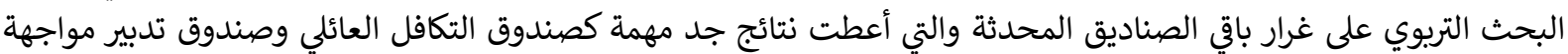
وباء فيروس كورونا " كوفيد ـ 19...إخت.

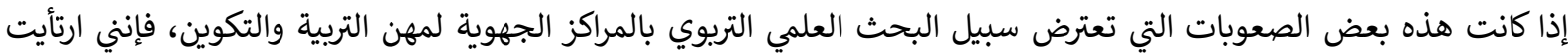

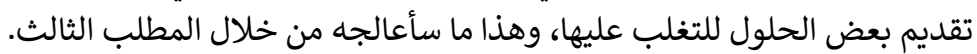

\section{المطلب الثالث: بعض آليات تطوير البحث العلمي بالمراكز الجهوية لمهن التربية والتكوين}

لتجاوز الإكراهات والصعوبات السالف ذكرها والتي واجهت وستواجه إرساء بنيات متطورة للبحث العلمي التربوي بالمراكز

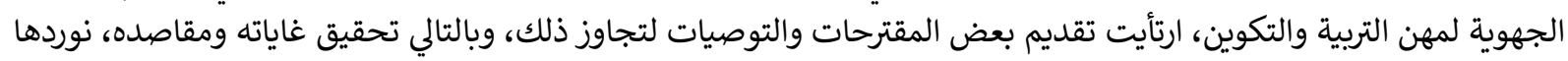
فيما يلي: 
ـ التعجيل بإصدار النصوص القانونية المنظمة لمقتضيات مرسوم إحداث المراكز الجهوية لمهن التربية والتكوين (المرسوم رقم

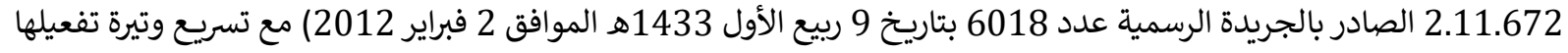

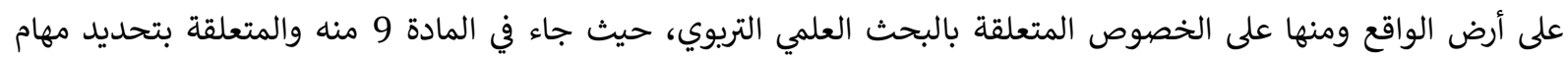

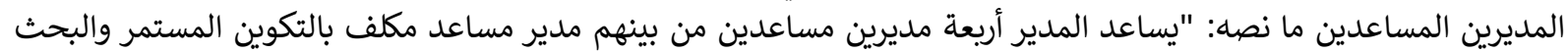

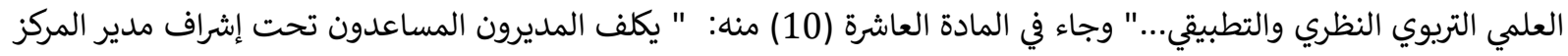

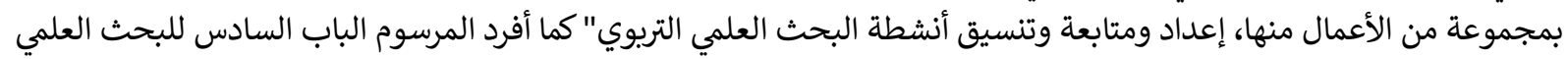

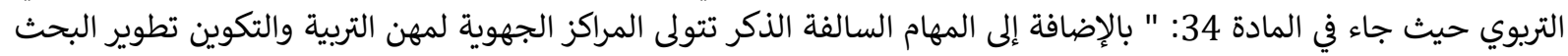

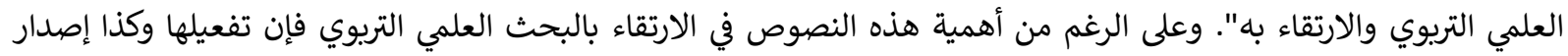

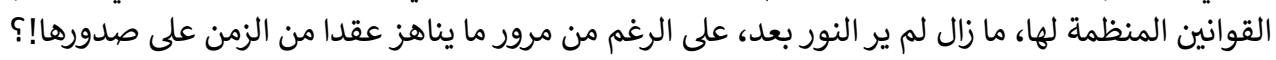

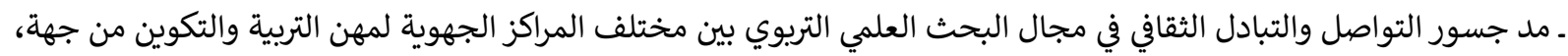

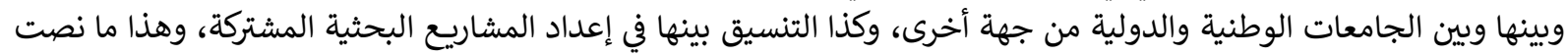

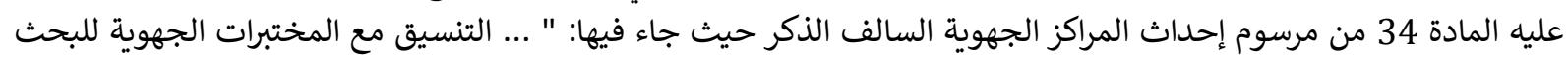

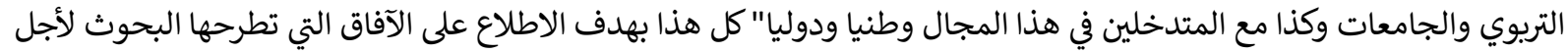

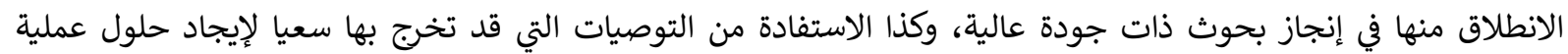

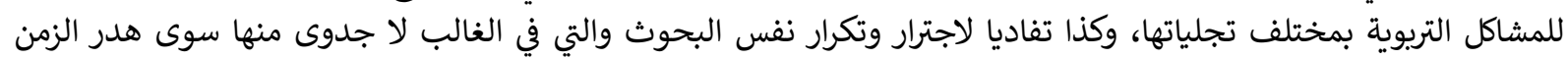
والمال الذي نحن في أمس الحاجة إليهما.

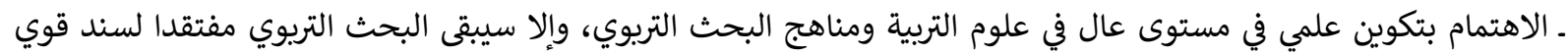

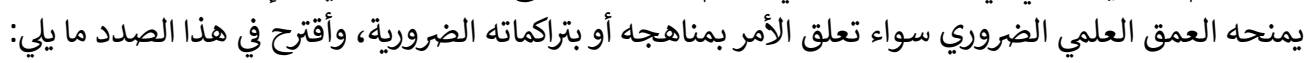

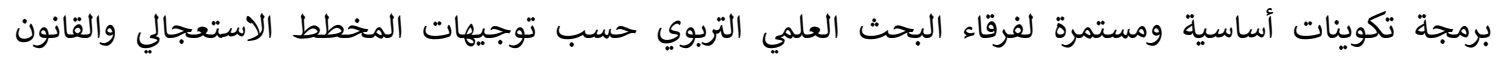

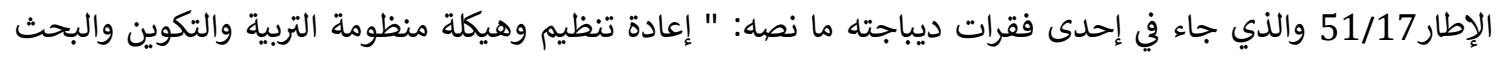

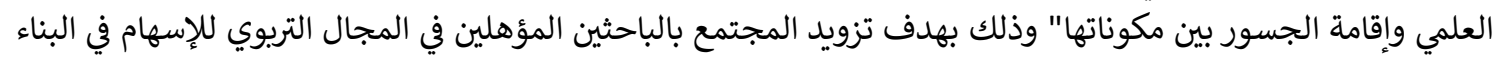

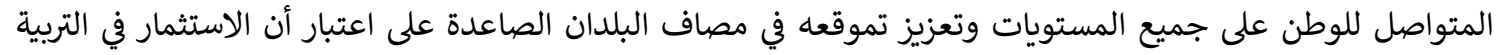

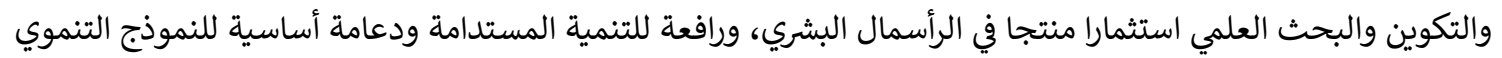
للبلاد. تزويد المركز بكفاءات وأطر مؤهلة في مجال البحث التربوي وتكليفها بتدريس مجزوئ الترة البحث التربوي نظرا للخصاص

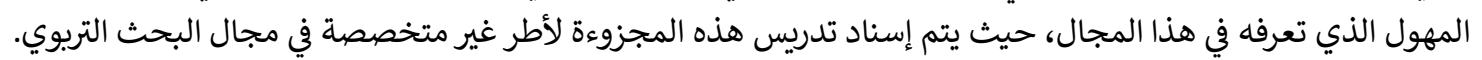

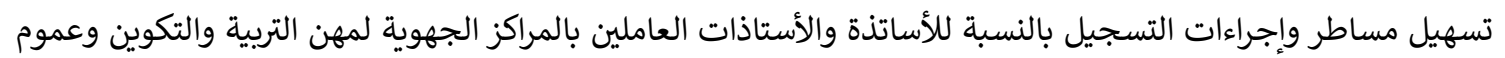

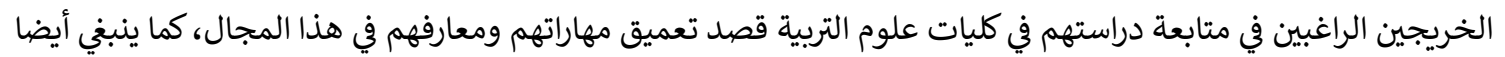

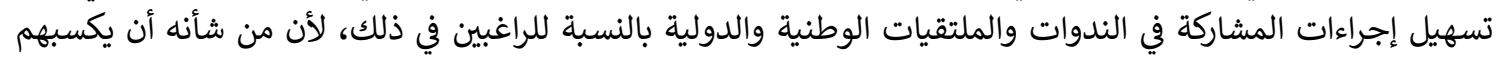

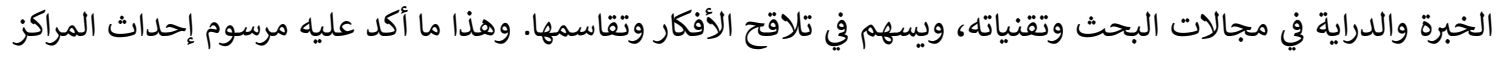

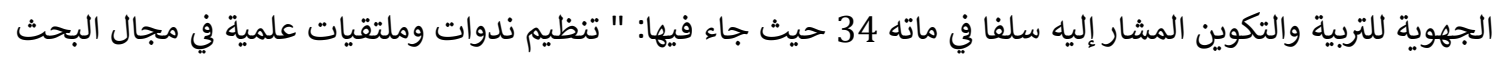

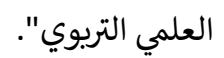

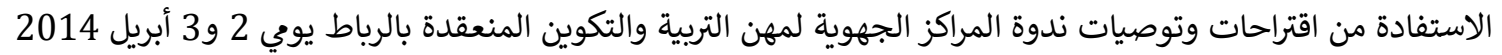

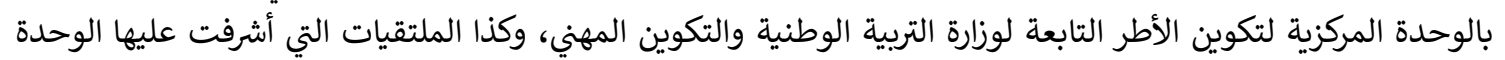

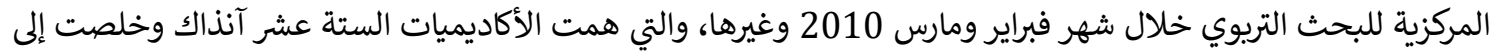

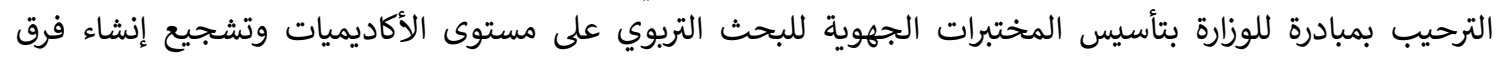

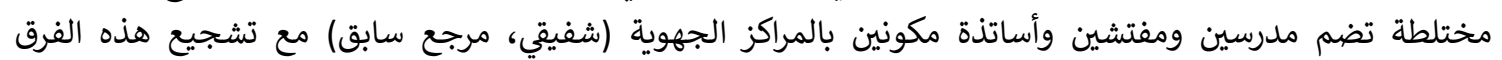

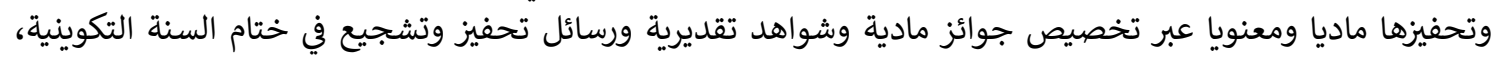

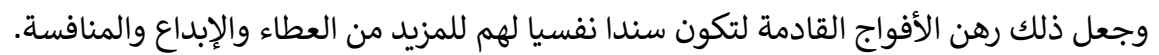

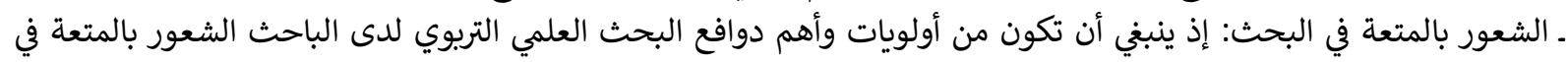

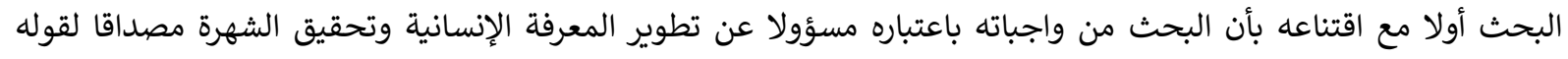

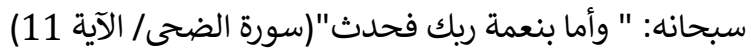
ثانيا: الحصول على الترقية الأكاديمية والمكافآت المالية، ولا شك الكآن أن ذلك سيساهم في الرقي بالبحث العلمي إلى مصاف الدول 


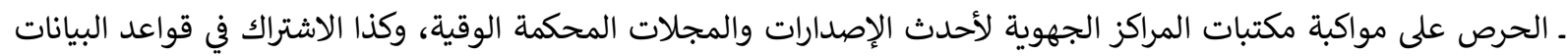

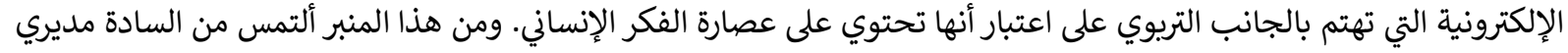

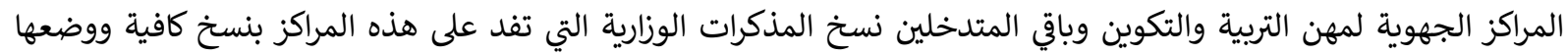

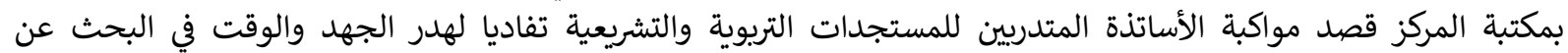
المعلومات اللازمة.

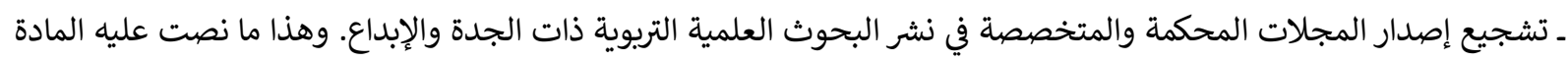

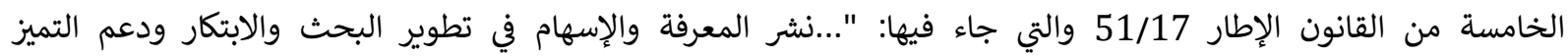

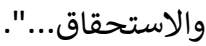
ـ ـ إحداث مكاتب قارة لفرق البحان البحث ومختبراته بالمراكز الجهوية لمهن التربية والتكوين على غرار ما هو معمول به بالجامعات

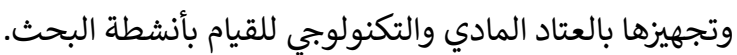

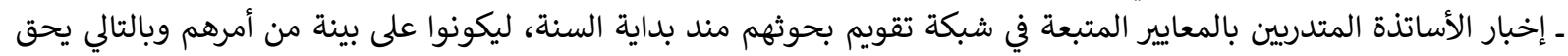

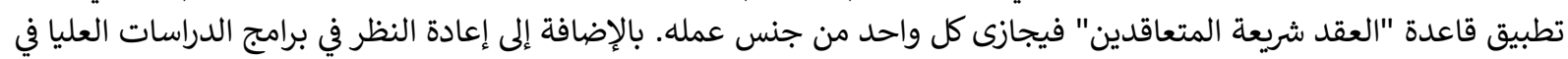

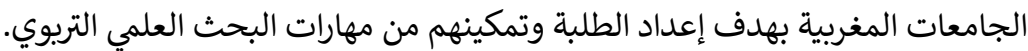

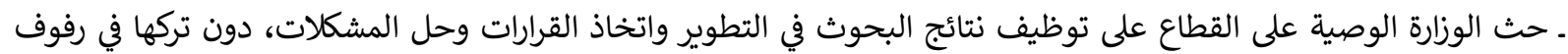
المكتبات يطالها النسيان ويعلوها الغبار.

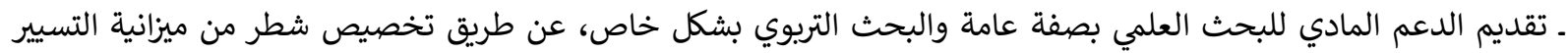

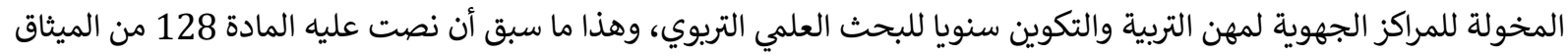

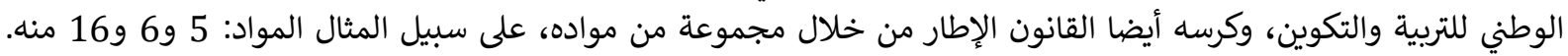

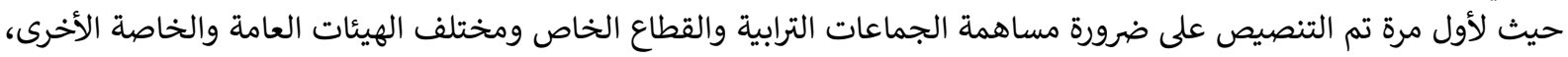

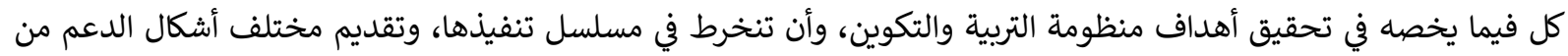

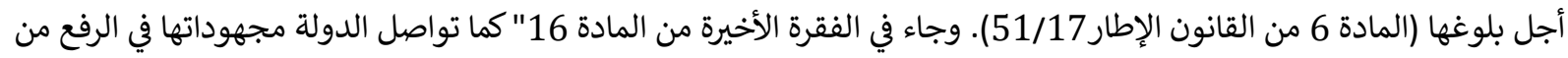

$$
\text { الميزانية العامة لتشجيع البحث العلمي" البحة }
$$

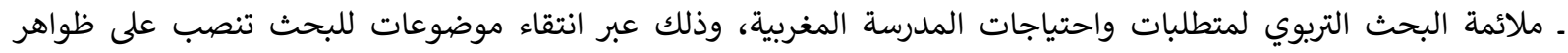

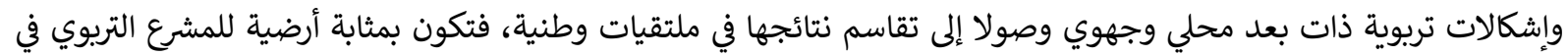

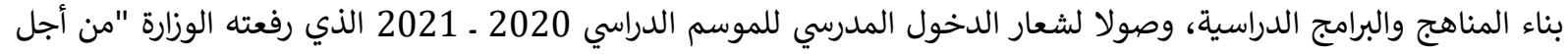

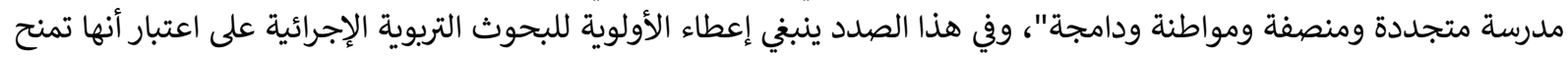

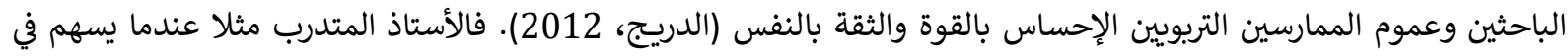

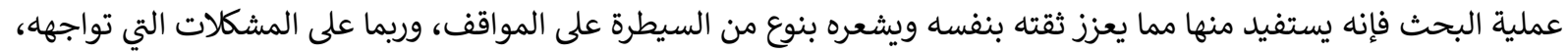

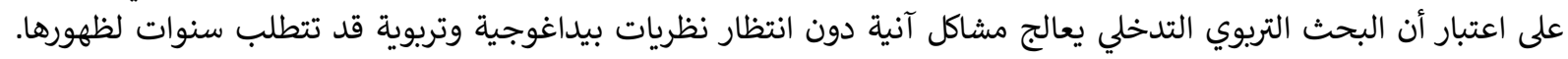

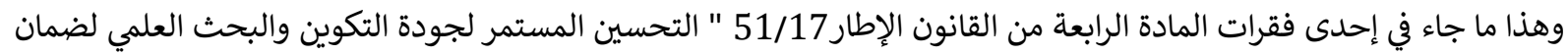

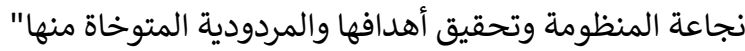

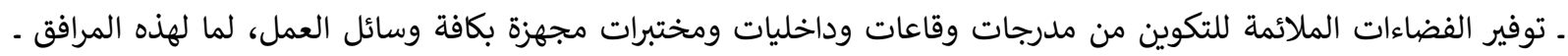

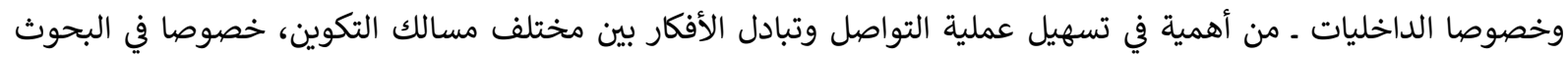

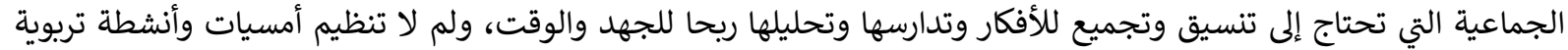
بالمركز ومؤسسات التطبيق.

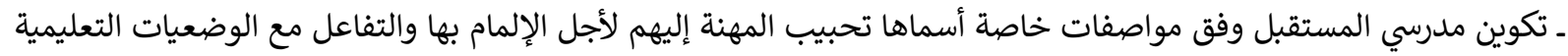

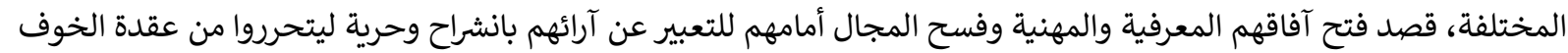

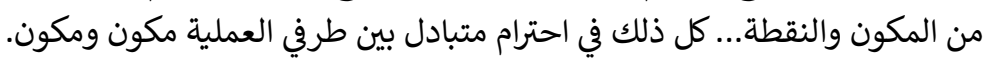

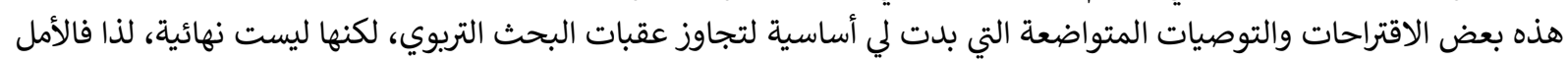

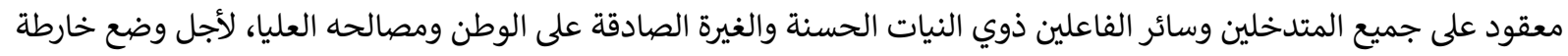

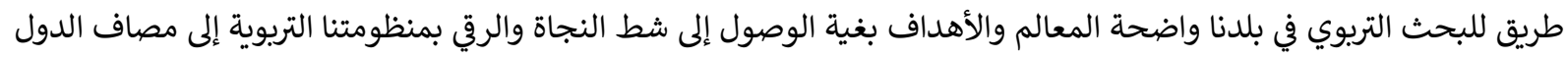

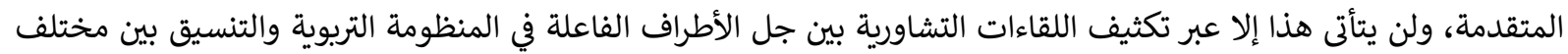

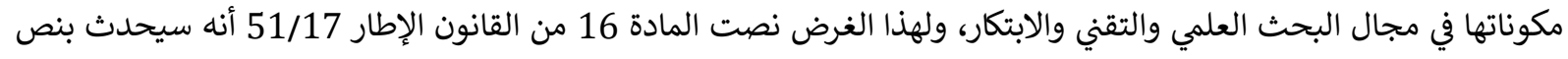

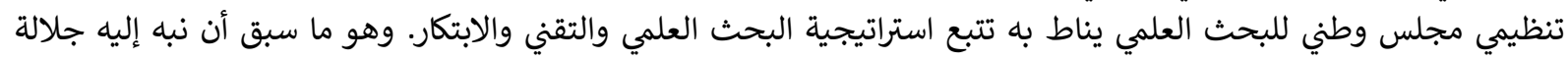

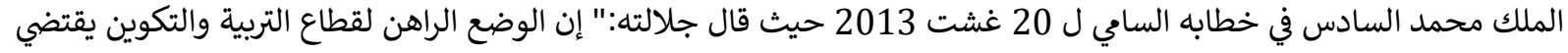

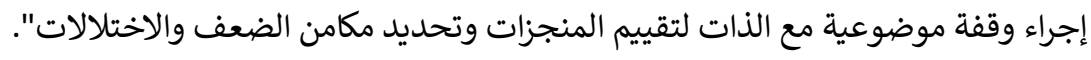


II. International Congress of Humanities and Educational Research (IJHER Congress 2)

لائحة المصادر والمراجع المعتمدة

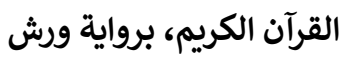

الجاذري عدنان وأبو حلو يعقوب، 2009، الأسس المنهجية والاستخدامات الإحصائية في بحوث العلوم التربوية والإنسانية، إسراء لـ النشر والتوزيع، عمان الأردن.

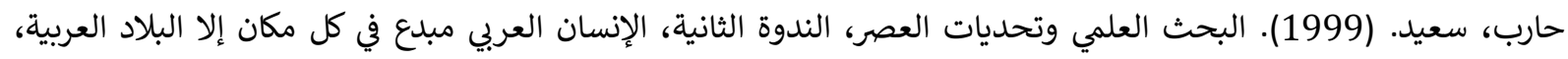

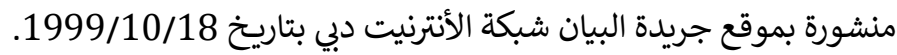

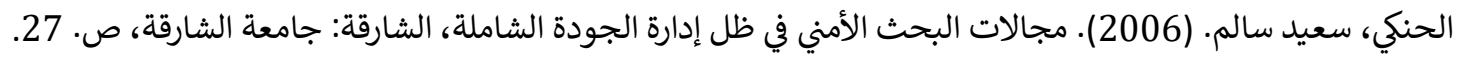

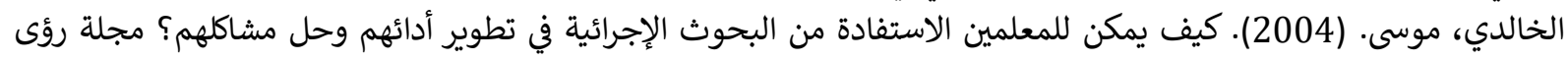

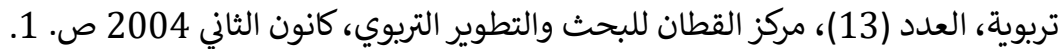

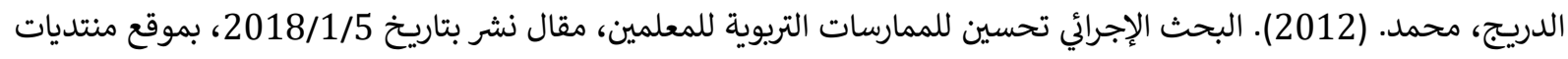

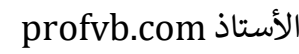

ديواني، محمد. (1997). البحث التريوي في كليات التربية ووسائل تطويره، ورقة مقدمة إلى المؤتمر التربوي الذي عقد في كلية

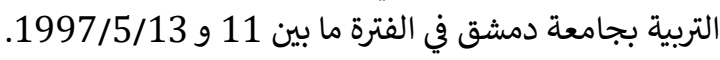

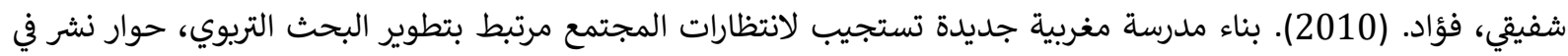

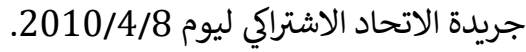

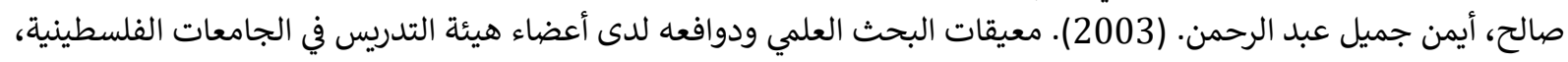

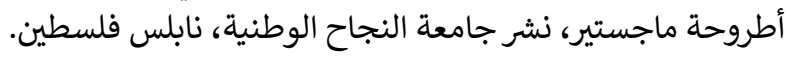

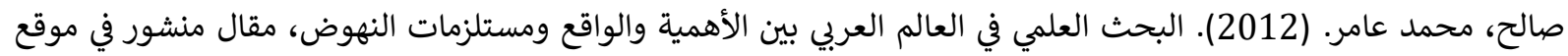

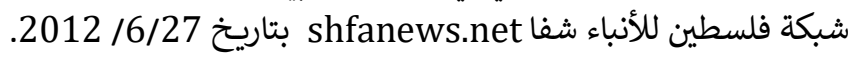

عمار، حامد. (2013). تعليم المستقبل من التسلط إلى التحرر، (ط1)، الدياء الدار المصرية اللبنانية، القاهرة.

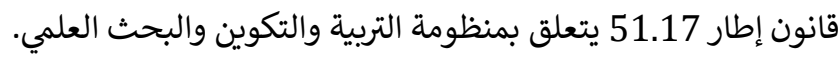

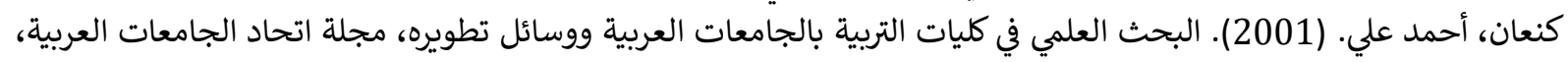
العدد (38)، ص.5 (200). التيحث

المجلس الأعلى للتربية والتكوين والبحث العلمي. من أجل مدرسة الإنصاف والجودة والارتقاء، رؤية استراتيجية للإصلاح 2015 ـ. 2030

المخطط الاستعجالي (2009 ـ 2012) لإصلاح منظومة التربية والتكوين.

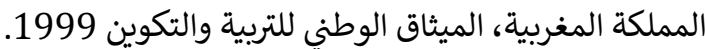
المملكة المغربية، النموذج التنموي الجديد، تحرية التربية النمائ الطاقات واستعادة الثقة لتسريع وتيرة التقدم وتحقيق الرفاه للجميع، التقرير

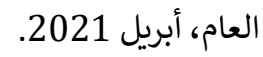

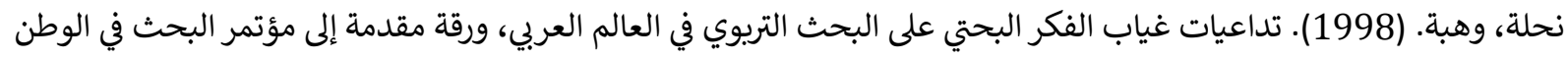

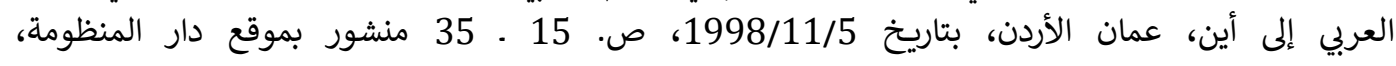
search.mandumah.com 
EVALUATION OF EDUCATIONAL TELEVISION LESSONS FOR INTERMEDIATE SCHOOL BIOLOGY ACCORDING TO PROPOSED STANDARDS

Omar Falah Awad AL-JANABI \& Ameer Mohammed Ali Rasool AL-SADI 


\title{
EVALUATION OF EDUCATIONAL TELEVISION LESSONS FOR INTERMEDIATE SCHOOL BIOLOGY ACCORDING TO PROPOSED STANDARDS
}

\author{
Omar Falah Awad Al-JANABI ${ }^{1}$ \\ Ameer Mohammed Ali Rasool AL-SADI ${ }^{2}$
}

\begin{abstract}
:
The research aimed at evaluating educational television lessons for science for the primary stage according to proposed criteria. Three main fields are (scientific and cognitive field, educational field, performance field) from which (11) criteria and (44) indicators emerge, The two researchers evaluated the educational television lessons of science for the primary stage for the academic year (2020-2021) according to these criteria and indicators, with a number of lessons that amounted to (89) lessons out of (89), and the researchers extracted the validity of the evaluation; This was done through the assistance of two experts in the field of education / methods of teaching science. The two researchers analyzed a random sample of lessons, and then presented the assessed lessons and the proposed assessment criteria and their indicators to the two experts, and they unanimously agreed on the validity of the assessment. Then, they extracted the stability of the calendar by the methods of stability over time and stability between the two evaluators using Holstey's equation. The results showed that all standards were met in the educational television lessons of science for all primary schools, and that the degree of their achievement was significant.
\end{abstract}

Key words: Evaluation, Standards.

http://dx.doi.org/10.47832/ijhercongress2-3

${ }^{1}$ Babylon Education Directorate, Iraq, Omarfalah44@ gmail.com, https://orcid.org/0000-0003-3609-4806

${ }^{2}$ Karbala Education Directorate, Iraq, Ameeralsadi72@ @mail.com, https://orcid.org/0000-0001-9029-0117 


\title{
تقويم دروس التلفزيون التربوي لمادة العلوم للمرحلة الابتدائية على وفق معايير مقترحة
}

\author{
3 عمر فلاح عواد الجنابي \\ أمير محمد علي رسول السعدي عماد الجني
}

الملخص:

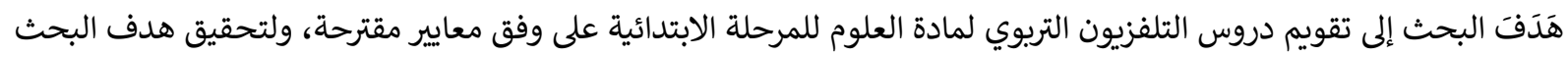

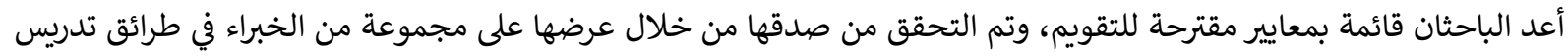

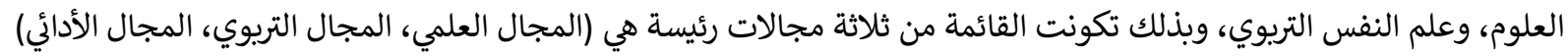

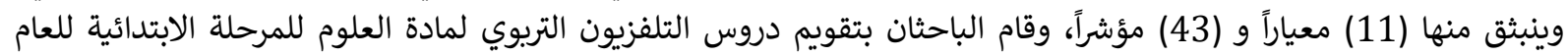

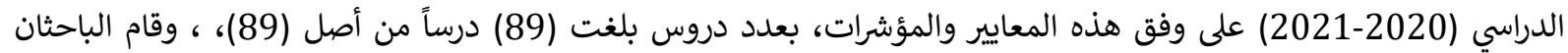

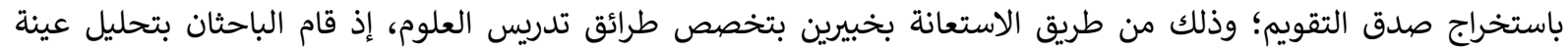

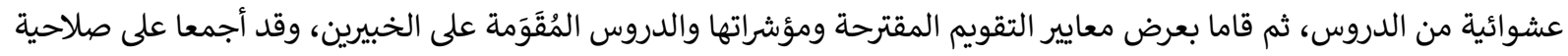

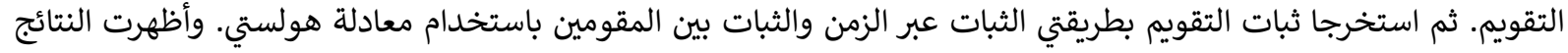

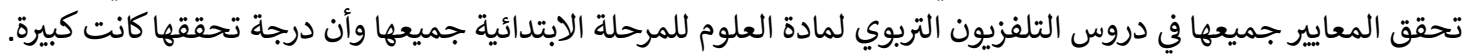
الكلمات المفتاحية: التقويم، المعايير.

مشكلة البحث (Research Problem)

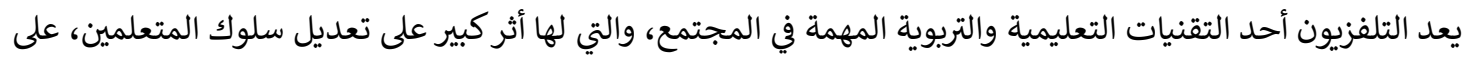

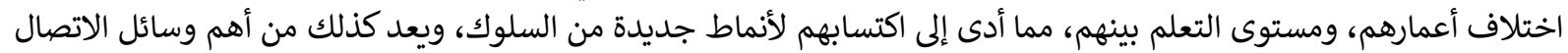

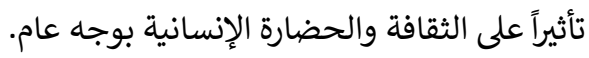

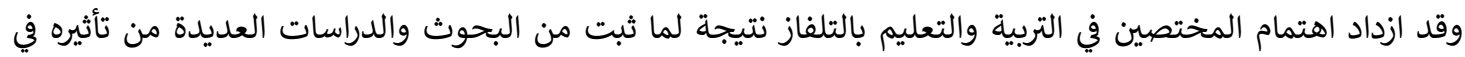

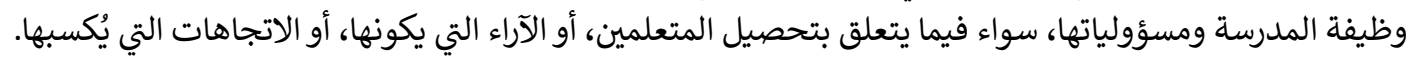

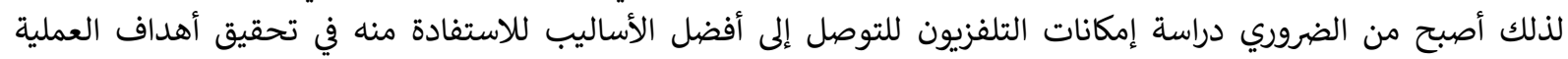

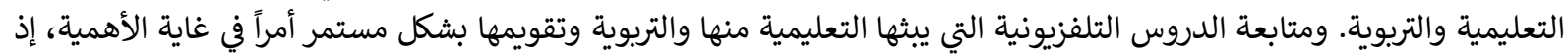

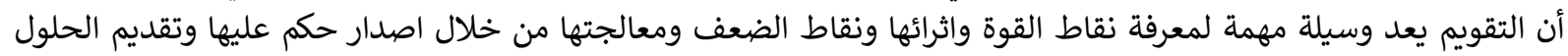
المناسبة.

\section{وبذلك تتحدد مشكلة البحث في الإجابة عن التساؤل الآتي:}

س- ما درجة تحقيق دروس التلفزيون التربوي لمعايير مقترحة للتقويم؟

أهمية البحث (Research Importance)

1- يُعد هذا البحث أول بحث- على حلى حد علم الباحِثَين- في العراق يتناول تقويم دروس التلفزيون التربوي لمادة العلوم للمرحلة الابتدائية على وفق معايير مقترحة.

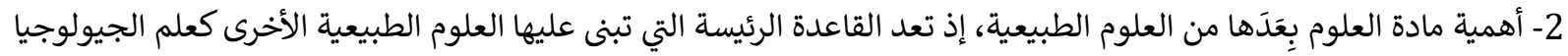

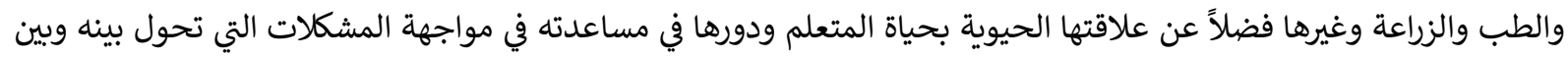
تحقيق أهدافه.

3- أهمية المرحلة الابتدائية كونها مرحلة مهمة في تكوين شخصية المتعلم.

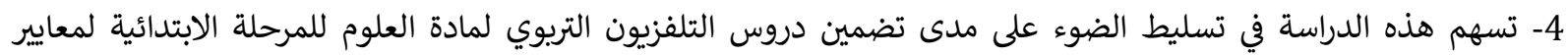

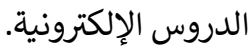

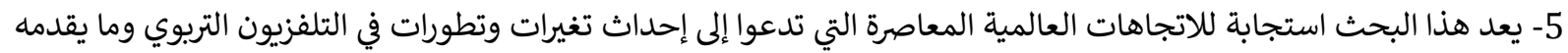

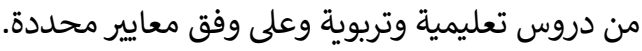
6- يتيح هذا البحث التعرف على نقاط القوة والضعف في في الدروس التي يقدمها التلفزيون التريوي. 
II. International Congress of Humanities and Educational Research (IJHER Congress 2)

7- يعد هذا البحث استجابة للتطورات الحاصلة في ظل جائحة كورونا.

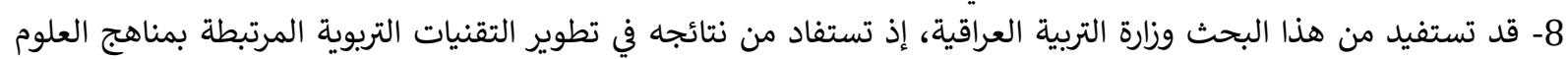

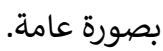

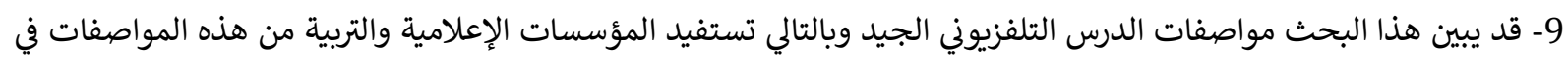

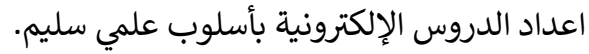
10- قد يشكل هذا البحث نواة لبحوث أخرى أبرى ولمراحل أُخر.

هدف البحث (Research Aim) تقويم دروس التلفزيون التربوي لمادة العلوم للمرحلة الابتدائية على وفق معايير مقترحة.

أسئلة البحث (Research Questions) س- ما درجة تحقيق دروس التلفزيون التربوي لمادة العلوم للمرحلة الابتدائية لمعايير مقترحة للتقويم؟ حدود البحث (Research Limits) اقتصر البحث على دروس التلفزيون التربوي لمادة العلوم للمرحلة الابتدائية للعام (2020-2021).

تحديد المصطلحات (Defining Terms)

(Evaluation) التقويم

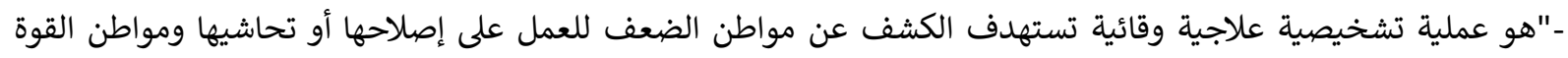
للعمل على إثرائها بقصد تحسين العملية التعليمية والتريوية وتطويرها بما يحقق الأهداف المنشودة". (فليلة وأحمد، 2004: -"هو اصدار حكم لغرض ما على قيمة الأفكار والأعمال والطرائق والمواد التعليمية ...إلخ وأنه يتضمن استخدام المحكات

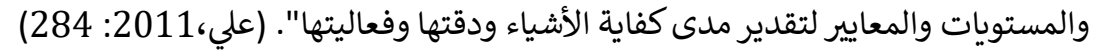

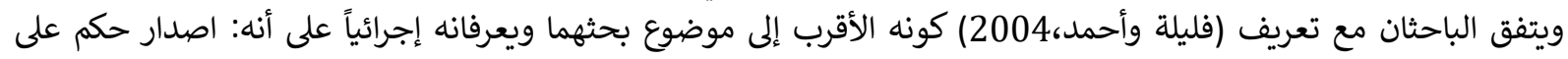

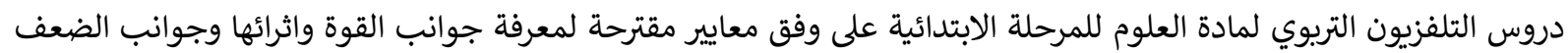
ومعالجتها.

(Standards) المعايير

ـ "هي أعلى مستويات الأداء التي يسعى الفرد للوصول إليها، ويتم في ضوئها تقويم مستويات الأداء المختلفة والحكم عليها". (السيد

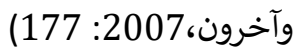
ـ"عبارات تشير إلى الحد الأدنى من الكفايات المطلوب تحقيقها لغرض معين ". (علي،2011: 164: 12011)

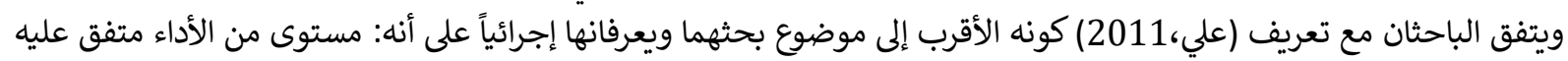
يتم على وفقه تقويم دروس التلفزيون التربوي لمادة العلوم للمرحلة الابتدائية.

خلفية نظرية (Theoretical Background)

أولاً: التقويم (Evaluation)

$$
\text { 1 1 أسس التقويم: المعايي. }
$$

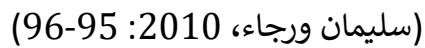




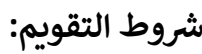

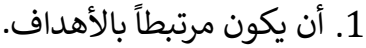
2. 2 أن يكون مبنياً على أسس علمية.

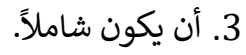

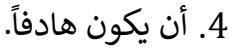
5. أن تكون أداوته وأساليبه محددة مسبقاً، ولا يجوز أن تكون ارتجالية.

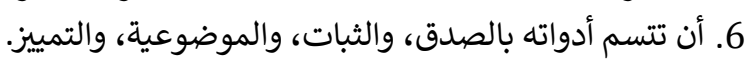
(عطية،2009: 266) (الساعدي وآخرون،2011: 41-42)

وظائف التقويم:

1. تشخيصي.

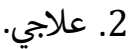
3. وقائي.

(الساعدي وآخرون، 2011: 39-40)

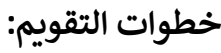
1. تحديد المعايير للجانب المراد تقويمه. 2. تحديد الأدوات اللازمة واعداها لجمع المعلومات والبيانات المناسبة المتصلة بالجانب المستولئ المستهدف.

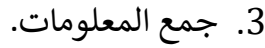

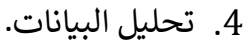
5. تفسير النتائج.

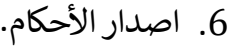
7. اتخاذ القرارات. (دعمس، إم، 2008: 13)

(Educational TV) ثانياً التلفزيون التربوي

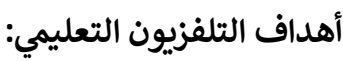
1. عرض الدروس والموضوعات التعليمية بطريقة تتسم بالوضوح على المشاهدة.

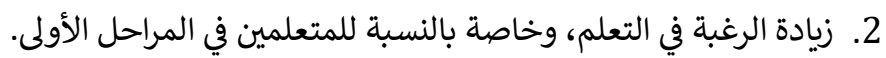

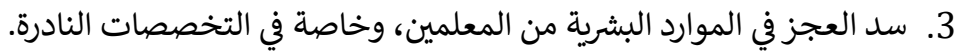
4. بث الدروس على نطاق واسع بتكاليف مناسبة نسبياً. 5. توفير درجة من الخصوصية في مشاهدة البرامج.

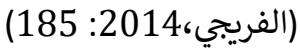

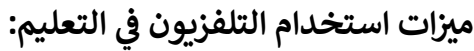

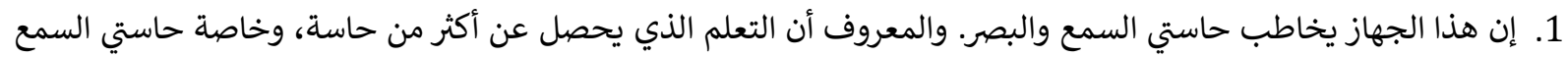

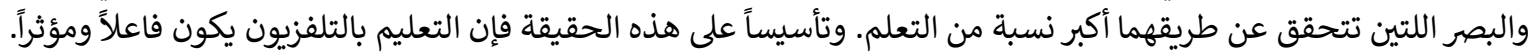
2. صلاحيته لتقديم المواد الدراسية جميعها وللمراحل كافة.

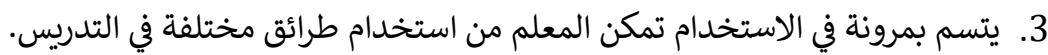

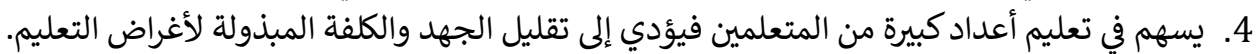

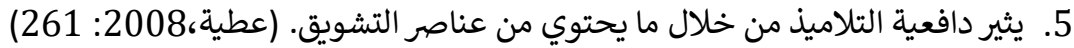

(Standards) (ثالثاً: المعايير -هي أعلى مستويات الأداء التي يسعى الفرد للوصول إليها، ويتم في ضوئها تقويم مستويات الأداء المختلفة والحكم عليها. (السيد وآخرون، (177 12007) 
II. International Congress of Humanities and Educational Research (IJHER Congress 2)

-هي مجموعة من الشروط المتفق عليها، ويمكن من خلال تطبيقها التعرف على مواطن الضعف والقوة فيما يراد تقويمه وإصدار

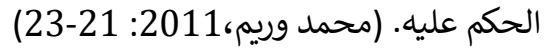
ويعرف المؤشر على أنه

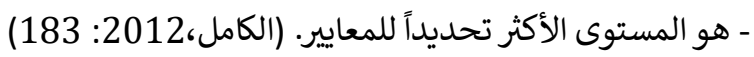

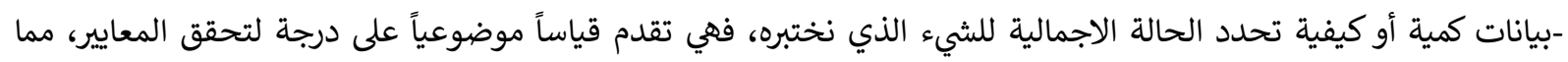

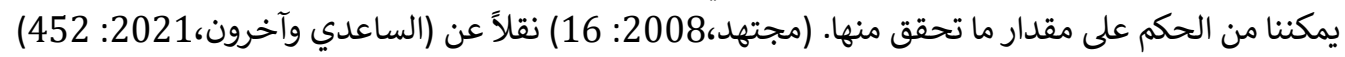

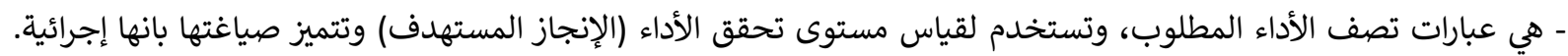
(الريبي،2013: (250)

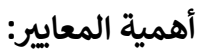

1- وضع مستويات معيارية، ومتوقعة، ومرغوبة، ومتفق عليها، للأداء بكل جوانبه.

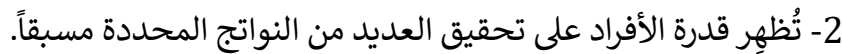

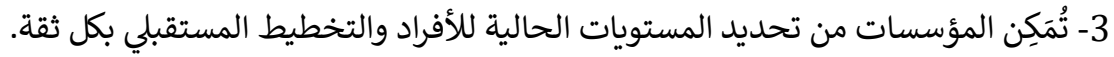
4- 5 - 5دم إطار ثابت ومستقر لإعداد التقارير. 5- التأكيد على النواحي الإيجابية لإنجازات الأفراد.

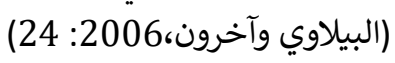

شروط صياغة المعايير: 1- الشمول: لابد أن تتناول المعايير الجوانب المختلفة وتكون قادرة على إحداث التكامل في المعلومات.

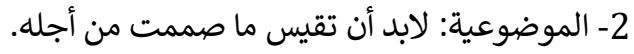

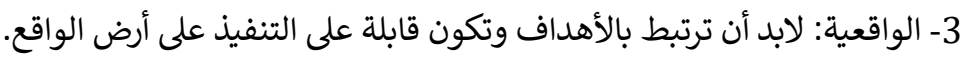

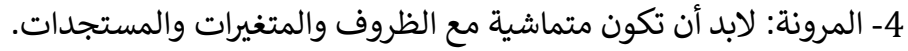

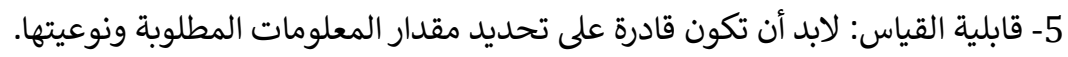

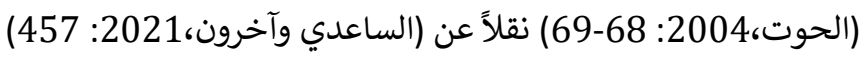

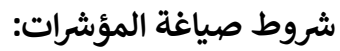
1- 2- أن تمثل مظهر من مظاهر الأداء. 2- 2- 2- أن تكون فعالة في التطوير.

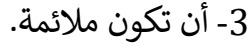
(الكامل،2012: أن نكون ملائة 184) نقلاً عن (الساعدي وآخرون،2021: 457)

دراسات سابقة (Previous Studies) دراسة (شحاتة،2005) (أحمد،2009) (الطائي وسحر،2012) (جيدوري،2013) (المطيري،2016) اجراءات البحث (Research Produces) أولاً: منهجية البحث (Research Methodology) اتبع الباحثان المنهج الوصفي التحليلي لتحقيق هَدَف البحث.

(Research community) ثانياً: مجتمع البحث دروس التلفزيون التربوي لمادة العلوم للمرحلة الابتدائية جميعها، (89) درساً، الجدول (1) يوضح ذلك. جدول (1) يوضح مجتمع البحث

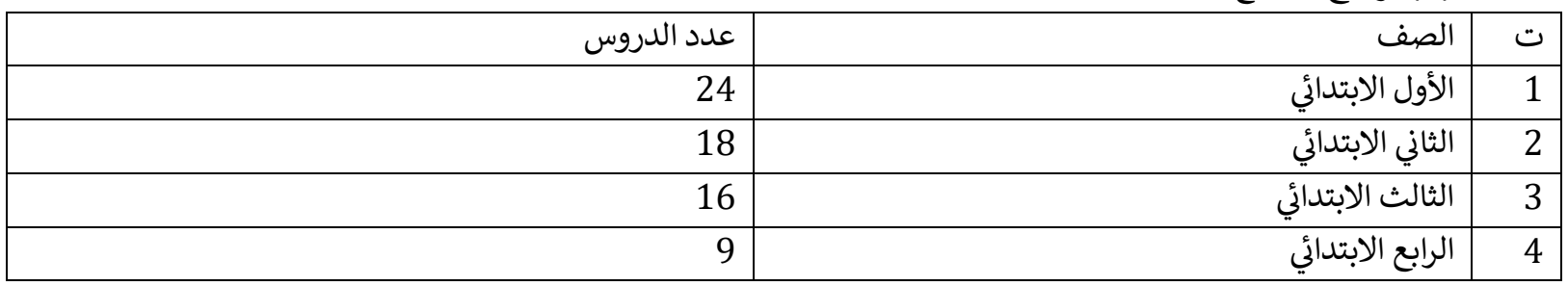


Full Text Book of IJHER Congress 2

\begin{tabular}{|r|r|r|}
\hline 12 & 5 \\
\hline 10 & الخامس الابتدائي & 5 \\
\hline
\end{tabular}

(Research sample) ثالثاً: عينة البحث

تم تحديد عينة دروس التلفزيون التربوي لمادة العلوم للمرحلة الابتدائية جميعها، والبالغ عددها (89) درساً للعام الدراسي

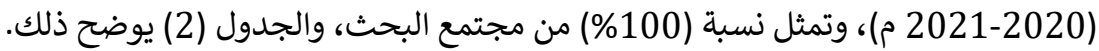

جدول (2) يوضح عينة البحث

\begin{tabular}{|c|c|c|c|c|}
\hline النسبة المئوية & عدد الدروس المقومة & عدد الدروس الكلي & الصف & ت \\
\hline$\% 100$ & 24 & 24 & الأول الابتدائي & 1 \\
\hline$\% 100$ & 18 & 18 & الثاني الابتدائي & 2 \\
\hline$\% 100$ & 16 & 16 & الثالث الابتدائي & 3 \\
\hline$\% 100$ & 9 & 9 & الرابع الابتدائي & 4 \\
\hline$\% 100$ & 12 & 12 & الخامس الابتدائي & 5 \\
\hline$\% 100$ & 10 & 10 & السادس الابتدائي & 6 \\
\hline$\% 100$ & 89 & 89 & & المج \\
\hline
\end{tabular}

رابعاً: أداة البحث (Research Tool)

تم اعداد قائمة معايير لتقويم دروس التلفزيون التربوي لمادة العلوم للمرحلة الابتدائية وكالآتي: 1- 2- الاطلاع على أدبيات ودراسات سابقة.

2- هدف الأداة: تقويم دروس التديات ودراسات التزيون التربوي لمادة العلوم للمرحلة الابتدائية.

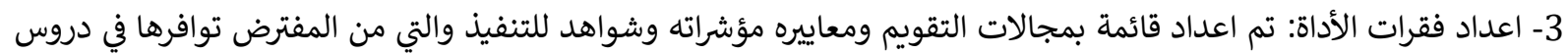

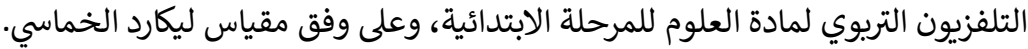

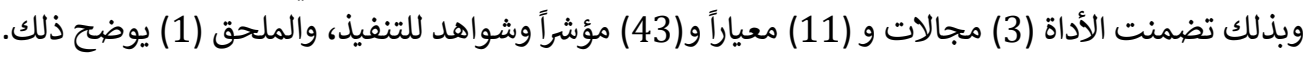

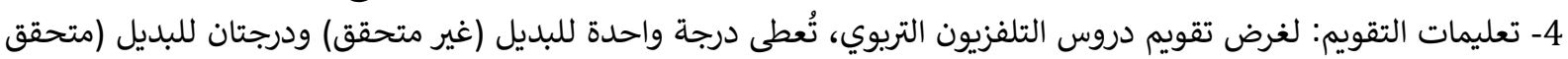

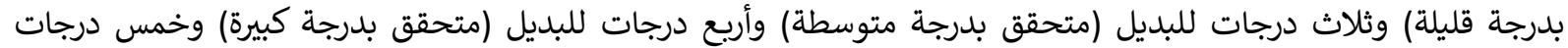

للبديل (متحقق بدرجة كبيرة جداً). ولحساب درجة تحقيق الدروس للمعايير تم حساب الآتي:

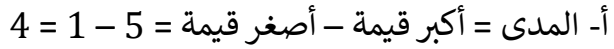

ب- الفترة = المدى / عدد الفئات = 4 / 4 / جدول (3) يوضح مستويات وتقدير التقويم

\begin{tabular}{|c|c|c|}
\hline التقدير & المستويات & ت \\
\hline غير متحقق & $1.80-1$ & 1 \\
\hline متحقق بدرجة قليلة & $2.60-1.81$ & 2 \\
\hline متحقق بدرجة متوسطة & $3.40-2.61$ & 3 \\
\hline متحقق بدرجة جيدة & $4.20-3.41$ & 4 \\
\hline متحقق بدرجة جيدة جداً & $5-4.21$ & 5 \\
\hline
\end{tabular}

خامساً: الصدق الظاهري للأداة (Validity of the Tool)

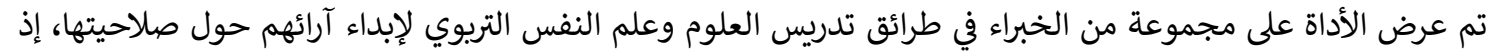

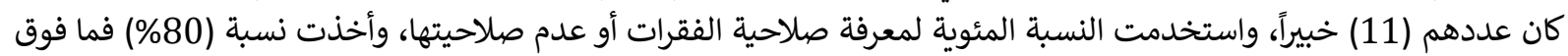

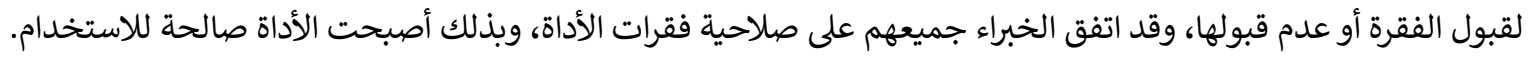

سادساً: صدق التقويم (Validity)

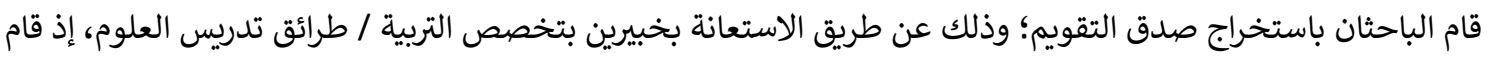

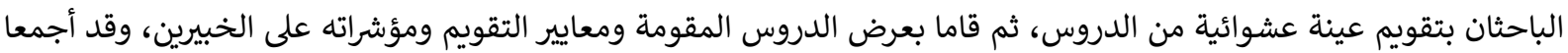
على صلاحية التقويم. 
II. International Congress of Humanities and Educational Research (IJHER Congress 2)

سابعاً: ثبات التقويم (Reliability)

ل لحساب ثبات التقويم استخدم الباحثين طريقتين هما:

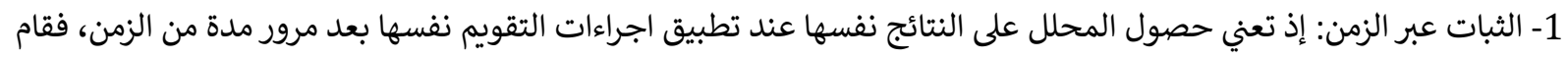

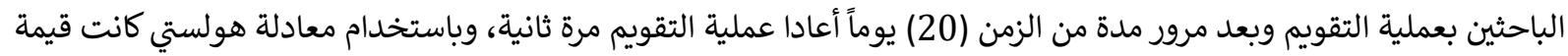

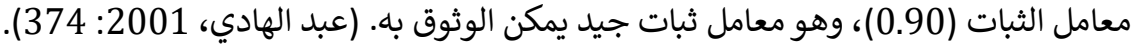

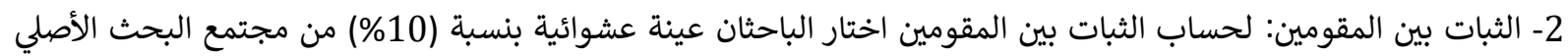

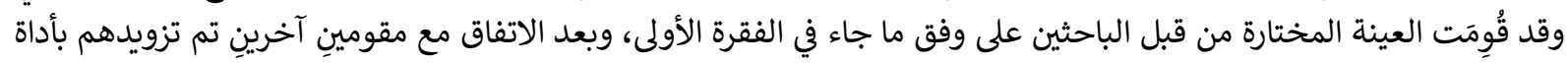

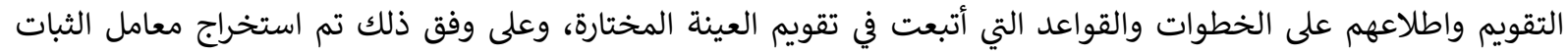

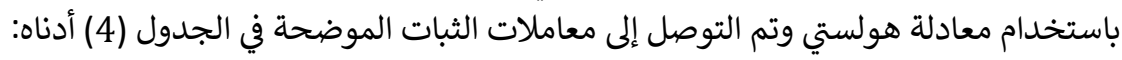
جدول (4) يوضح قيم معامل الثبات بين الباحث والمحلماتين الخارجيين

\begin{tabular}{|c|c|c|}
\hline قيم معامل الثبات & 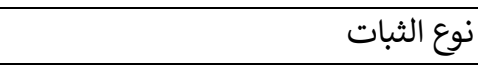 & ت \\
\hline 0.83 & الثبات بين الباحث والمُقوم الأول & 1 \\
\hline 0.85 & الثبات بين الباحث والمُقوم الثاني & 2 \\
\hline 0.82 & الثبات بين المقوم الأول والمُقوم الثاني & 3 \\
\hline
\end{tabular}

ثامناً: الوسائل الإحصائية استخدمت معادلة هولستي لمعرفة نسب الاتفاق بين المحللين

عرض النتائج (Presentation and interpretation of results) أولاً: نتائج تقويم دروس التلفزيون التربوي للصف الأول الابتدائي لمادة العلوم على وفق معايير مقترحة جدول (5) المتوسط الحسابي للمؤشرات والمعيار والمجالات لدروس العلوم للصف الأول الابتدائي

\begin{tabular}{|c|c|c|c|c|c|c|c|c|c|}
\hline \multirow{2}{*}{ المسابي } & \multirow[b]{2}{*}{ المط المسا } & \multicolumn{6}{|c|}{ المتوسط الحسابي للمؤشرات } & \multirow{2}{*}{ رقمم } & \multirow[t]{2}{*}{ المجال } \\
\hline & & 6r $^{2}$ & 5 & م4 & בp & م2 & ק & & \\
\hline \multirow[t]{2}{*}{3.93} & 4.14 & & & & 4.10 & 4.20 & 4.13 & 1 & \multirow[t]{2}{*}{ المجال العلمي للدرس } \\
\hline & 3.72 & 3.75 & 3.90 & 3.15 & 4.01 & 4.10 & 3.41 & 2 & \\
\hline \multirow[t]{4}{*}{3.68} & 3.90 & & 3.90 & 4.01 & 3.41 & 4.05 & 4.12 & 1 & \multirow[t]{4}{*}{ المجال التريوي للدرس } \\
\hline & 3.39 & & 3.41 & 3.48 & 3.49 & 3.17 & 3.42 & 2 & \\
\hline & 3.84 & & 3.99 & 3.80 & 3.81 & 3.47 & 4.17 & 3 & \\
\hline & 3.57 & & & 3.41 & 3.91 & 3.50 & 3.44 & 4 & \\
\hline \multirow[t]{5}{*}{3.31} & 3.39 & & & & & 3.38 & 3.40 & 1 & \multirow[t]{5}{*}{ المجال الأدائي للدرس } \\
\hline & 3.54 & 3.45 & 3.41 & 3.82 & 3.90 & 3.22 & 3.47 & 2 & \\
\hline & 3.70 & & & & 3.92 & 3.77 & 4.21 & 3 & \\
\hline & 3.26 & & & & & 3.13 & 3.40 & 4 & \\
\hline & 2.66 & & & & & 2.70 & 2.61 & 5 & \\
\hline 3.64 & 3.56 & & & & & & 43 & 11 & المجموع \\
\hline
\end{tabular}

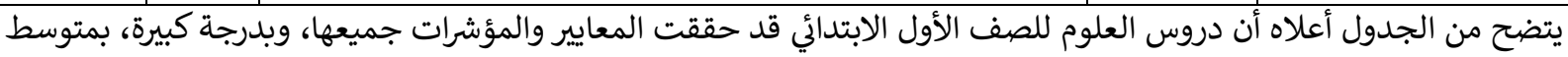

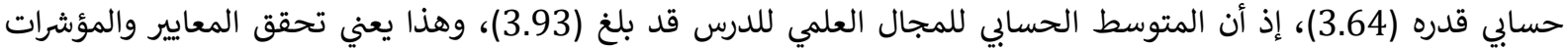

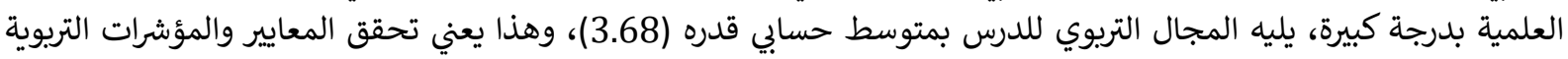
بدرجة كبيرة، يليه المجال الأدائي للدرس بمتوسط حسابي قدره (3.31)، وهذا يعني تحقق المبري المعايير والمؤشرات الأدائية بدرجة 
ثانياً: نتائج تقويم دروس التلفزيون التربوي للصف الثاني الابتدائي لمادة العلوم على وفق معايير مقترحة

جدول (6) المتوسط الحسابي للمؤشرات والمعيار والمجالات لدروس العلوم للصف الثاني الابتدائي

\begin{tabular}{|c|c|c|c|c|c|c|c|c|c|}
\hline \multirow{2}{*}{ الحسابي } & \multirow{2}{*}{ المسابي } & \multicolumn{6}{|c|}{ المتوسط الحسابي للمؤشرات } & \multirow{2}{*}{ رقم } & \multirow[t]{2}{*}{ 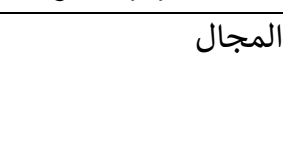 } \\
\hline & & 65 & 5 & م4 & م3 & 2 & 1) & & \\
\hline \multirow[t]{2}{*}{3.95} & 3.98 & & & & 3.79 & 4.15 & 4.00 & 1 & \multirow[t]{2}{*}{ المجال العلمي للدرس } \\
\hline & 3.92 & 4.01 & 3.70 & 3.49 & 4.41 & 4.11 & 3.81 & 2 & \\
\hline \multirow[t]{4}{*}{3.56} & 3.72 & & 3.41 & 3.97 & 3.88 & 3.94 & 3.41 & 1 & \multirow[t]{4}{*}{ المجال التربوي للدرس } \\
\hline & 3.63 & & 3.70 & 3.41 & 3.79 & 3.81 & 3.44 & 2 & \\
\hline & 3.64 & & 3.11 & 3.47 & 4.12 & 4.01 & 3.49 & 3 & \\
\hline & 3.25 & & & 3.01 & 3.12 & 3.14 & 3.74 & 4 & \\
\hline \multirow[t]{5}{*}{3.07} & 3.67 & & & & & 3.91 & 3.42 & 1 & \multirow[t]{5}{*}{ المجال الأدائي للدرس } \\
\hline & 3.17 & 2.54 & 3.81 & 3.07 & 3.01 & 3.57 & 3.00 & 2 & \\
\hline & 3.32 & & & & 3.71 & 3.20 & 3.05 & 3 & \\
\hline & 2.70 & & & & & 2.79 & 2.61 & 4 & \\
\hline & 2.56 & & & & & 2.33 & 2.80 & 5 & \\
\hline 3.52 & 3.41 & & & & & & 43 & 11 & المجموع \\
\hline
\end{tabular}

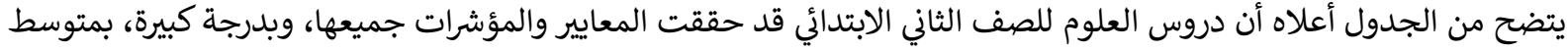

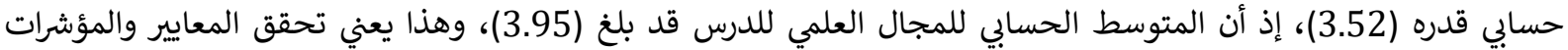

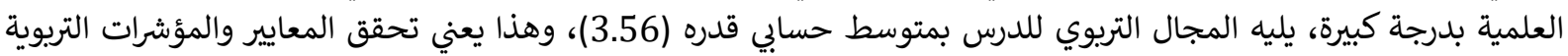

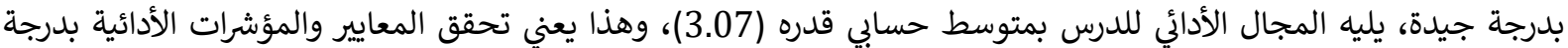

متوسطة.

ثالثاً: نتائج تقويم دروس التلفزيون التربوي للصف الثالث الابتدائي لمادة العلوم على وفق معايير مقترحة

جدول (7) المتوسط الحسابي للمؤشرات والمعيار والمجالات لدروس العلوم للصف الثالث الابتدائي

\begin{tabular}{|c|c|c|c|c|c|c|c|c|c|}
\hline \multirow{2}{*}{ المجسابي } & \multirow{2}{*}{ المسابي } & \multicolumn{6}{|c|}{ المتوسط الحسابي للمؤشرات } & \multirow{2}{*}{ رقعيار } & \multirow[t]{2}{*}{ المجال } \\
\hline & & pe & م5 & م4 & 3 & 2 ק & م & & \\
\hline \multirow[t]{2}{*}{3.99} & 4.04 & & & & 4.12 & 4.00 & 4.01 & 1 & \multirow[t]{2}{*}{ المجال العلمي للدرس } \\
\hline & 3.95 & 4.01 & 4.00 & 4.12 & 4.00 & 4.21 & 3.41 & 2 & \\
\hline \multirow[t]{4}{*}{3.51} & 3.44 & & 3.71 & 3.20 & 3.51 & 3.42 & 3.39 & 1 & \multirow[t]{4}{*}{ المجال التربوي للدرس } \\
\hline & 3.12 & & 3.00 & 3.17 & 3.20 & 3.10 & 3.12 & 2 & \\
\hline & 3.84 & & 3.74 & 3.81 & 3.77 & 3.91 & 4.00 & 3 & \\
\hline & 3.64 & & & 3.43 & 3.72 & 4.00 & 3.41 & 4 & \\
\hline \multirow[t]{5}{*}{3.11} & 3.31 & & & & & 3.21 & 3.41 & 1 & \multirow[t]{5}{*}{ المجال الأدائي للدرس } \\
\hline & 3.24 & 3.27 & 3.25 & 3.41 & 3.20 & 3.13 & 3.17 & 2 & \\
\hline & 3.48 & & & & 3.49 & 3.51 & 3.44 & 3 & \\
\hline & 3.04 & & & & & 3.00 & 3.09 & 4 & \\
\hline & 2.48 & & & & & 2.47 & 2.49 & 5 & \\
\hline 3.54 & 3.42 & & & & & & 43 & 11 & المجموع \\
\hline
\end{tabular}

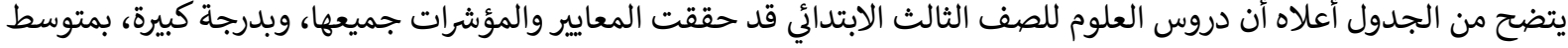

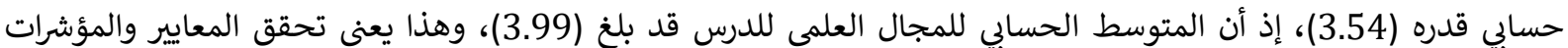

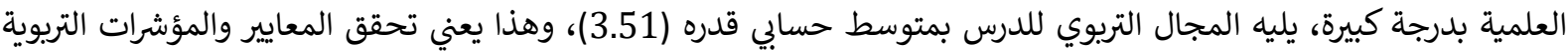


II. International Congress of Humanities and Educational Research (IJHER Congress 2)

بدرجة كبيرة، يليه المجال الأدائي للدرس بمتوسط حسابي قدره (3.11)، وهذا يعني تحقق المعايير والمؤشرات الأدائية بدرجة متوسطة. رابعاً: نتائج تقويم دروس التلفزيون التربوي للصف الرايع الابتدائي لمادة العلوم على وفق معايير مقترحة جدول (8) المتوسط الحسابي للمؤشرات والمعيار والمجالات لدروس العلوم للصف الرابع الابتدائي

\begin{tabular}{|c|c|c|c|c|c|c|c|c|c|}
\hline \multirow{2}{*}{ المسابي المجال } & \multirow{2}{*}{ المسابي } & \multicolumn{6}{|c|}{ المتوسط الحسابي للمؤشرات } & \multirow{2}{*}{ رقميار } & \multirow[t]{2}{*}{ 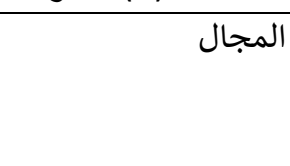 } \\
\hline & & r6 & 5 & م4 & 3 & م2 & م & & \\
\hline \multirow[t]{2}{*}{3.94} & 3.96 & & & & 3.78 & 4.10 & 4.00 & 1 & \multirow[t]{2}{*}{ المجال العلمي للدرس } \\
\hline & 3.90 & 4.00 & 3.68 & 3.45 & 4.39 & 4.09 & 3.79 & 2 & \\
\hline \multirow[t]{4}{*}{3.53} & 3.68 & & 3.41 & 3.90 & 3.85 & 3.90 & 3.37 & 1 & \multirow[t]{4}{*}{ المجال التربوي للدرس } \\
\hline & 3.62 & & 3.71 & 3.41 & 3.75 & 3.81 & 3.45 & 2 & \\
\hline & 3.60 & & 3.10 & 3.44 & 4.00 & 4.00 & 3.50 & 3 & \\
\hline & 3.23 & & & 3.00 & 3.12 & 3.10 & 3.70 & 4 & \\
\hline \multirow[t]{5}{*}{3.17} & 3.65 & & & & & 3.90 & 3.40 & 1 & \multirow[t]{5}{*}{ المجال الأدائي للدرس } \\
\hline & 3.35 & 3.00 & 3.84 & 3.49 & 3.01 & 3.55 & 3.21 & 2 & \\
\hline & 3.32 & & & & 3.69 & 3.21 & 3.06 & 3 & \\
\hline & 3.00 & & & & & 3.00 & 3.00 & 4 & \\
\hline & 2.54 & & & & & 2.34 & 2.75 & 5 & \\
\hline 3.54 & 3.43 & & & & & & 43 & 11 & المجموع \\
\hline
\end{tabular}

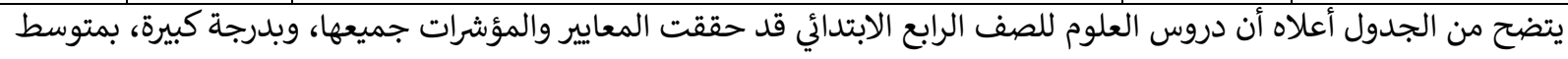

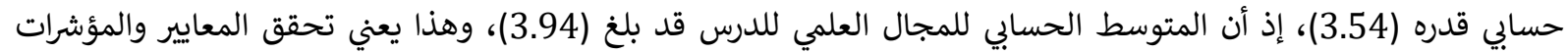

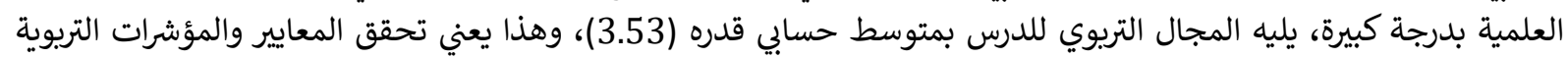

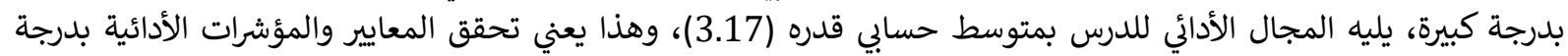
متوسطة. خامساً: نتائج تقويم دروس التلفزيون التربوي للصف الخامس الابتدائي لمادة العلوم على وفق معايير مقترحة جدول (9) المتوسط الحسابي للمؤشرات والمعيار والمجالات لدروس العلوم للصف الخامس الابتدائي

\begin{tabular}{|c|c|c|c|c|c|c|c|c|c|}
\hline \multirow{2}{*}{ المسابي } & \multirow{2}{*}{ المسابي } & \multicolumn{6}{|c|}{ المتوسط الحسابي للمؤشرات } & \multirow{2}{*}{ رقمي } & \multirow[t]{2}{*}{ المجال } \\
\hline & & 2 & מ5 & מ4 & 3 & 2 p & م & & \\
\hline \multirow[t]{2}{*}{3.99} & 3.99 & & & & 4.00 & 3.97 & 4.00 & 1 & \multirow[t]{2}{*}{ المجال العلمي للدرس } \\
\hline & 3.99 & 3.95 & 4.03 & 3.91 & 4.01 & 4.00 & 4.05 & 2 & \\
\hline \multirow[t]{4}{*}{3.69} & 3.45 & & 3.70 & 3.20 & 3.41 & 3.51 & 3.45 & 1 & \multirow[t]{4}{*}{ المجال التريوي للدرس } \\
\hline & 3.67 & & 3.41 & 3.44 & 4.01 & 4.00 & 3.49 & 2 & \\
\hline & 3.94 & & 4.09 & 3.45 & 4.39 & 4.00 & 3.79 & 3 & \\
\hline & 3.72 & & & 3.41 & 3.74 & 3.90 & 3.85 & 4 & \\
\hline \multirow[t]{5}{*}{3.23} & 3.32 & & & & & 3.20 & 3.44 & 1 & \multirow[t]{5}{*}{ المجال الأدائي للدرس } \\
\hline & 3.28 & 3.28 & 3.30 & 3.39 & 3.13 & 3.20 & 3.41 & 2 & \\
\hline & 3.50 & & & & 3.54 & 3.50 & 3.48 & 3 & \\
\hline & 3.31 & & & & & 3.22 & 3.40 & 4 & \\
\hline & 2.75 & & & & & 2.59 & 2.61 & 5 & \\
\hline 3.63 & 3.53 & & & & & & 43 & 11 & المجموع \\
\hline
\end{tabular}




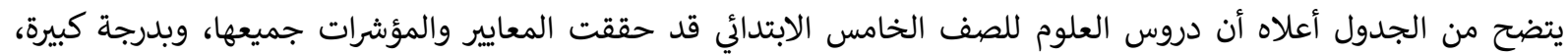

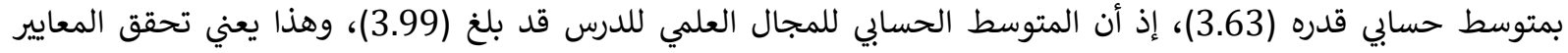

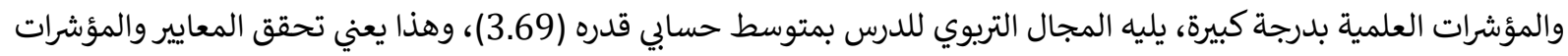
التربوية بدرجة كبيرة، يليه المجال الأدائي للدرس بمتوسط حسابي قدره (3.23)، وهذا يعني تحقق المعايير والمؤشرات الأدائية

بدرجة متوسطة.

سادساً: نتائج تقويم دروس التلفزيون التربوي للصف السادس الابتدائي لمادة العلوم على وفق معايير مقترحة

جدول (10) المتوسط الحسابي للمؤشرات والمعيار والمجالات لدروس العلوم للصف السادس الابتدائي

\begin{tabular}{|c|c|c|c|c|c|c|c|c|c|}
\hline \multirow{2}{*}{ المسابي } & \multirow{2}{*}{ المسابي } & \multicolumn{6}{|c|}{ المتوسط الحسابي للمؤشرات } & \multirow{2}{*}{ رقمي } & \multirow[t]{2}{*}{ المجال } \\
\hline & & r & م5 & م4 & م3 & 2 ק & $1_{r}$ & & \\
\hline \multirow[t]{2}{*}{3.93} & 3.91 & & & & 3.79 & 4.00 & 3.94 & 1 & \multirow[t]{2}{*}{ المجال العلمي للدرس } \\
\hline & 3.94 & 4.00 & 3.90 & 3.82 & 3.91 & 4.00 & 4.01 & 2 & \\
\hline \multirow[t]{4}{*}{3.70} & 3.64 & & 3.79 & 3.42 & 3.80 & 3.79 & 3.44 & 1 & \multirow[t]{4}{*}{ المجال التربوي للدرس } \\
\hline & 3.68 & & 3.44 & 3.91 & 3.86 & 3.84 & 3.38 & 2 & \\
\hline & 3.83 & & 3.76 & 3.74 & 3.81 & 4.00 & 3.87 & 3 & \\
\hline & 3.68 & & & 3.52 & 3.41 & 4.00 & 3.80 & 4 & \\
\hline \multirow[t]{5}{*}{3.27} & 3.67 & & & & & 3.45 & 3.89 & 1 & \multirow[t]{5}{*}{ المجال الأدائي للدرس } \\
\hline & 3.30 & 3.25 & 3.24 & 3.42 & 3.41 & 3.20 & 3.30 & 2 & \\
\hline & 3.47 & & & & 3.50 & 3.47 & 3.44 & 3 & \\
\hline & 3.35 & & & & & 3.41 & 3.30 & 4 & \\
\hline & 2.56 & & & & & 2.57 & 2.55 & 5 & \\
\hline 3.63 & 3.54 & & & & & & 43 & 11 & المجموع \\
\hline
\end{tabular}

يتضح من الجدول أعلاه أن دروس العلوم للصف السادس الابتدائي قد حققت المعايير والمؤشرات جميعها، وبدرجة كبيرة،

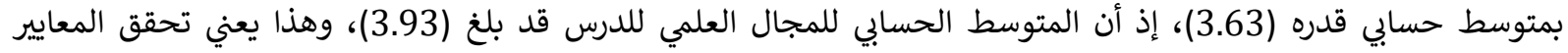

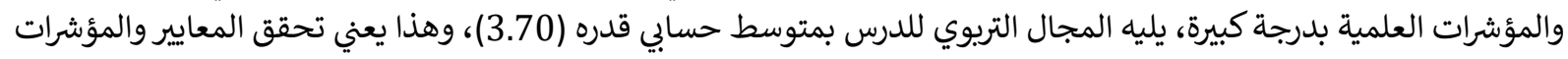

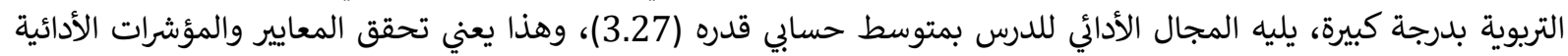

بدرجة متوسطة.

(Conclusions) الاستنتاجات

توصل الباحثان إلى الاستنتاجات الآتية: 1- تَحَقُقُ المعايير جميعها في دروس الاستنات التئنة التفزيون التربوي لمادة العلوم للمرحلة الابتدائية جميعها. 2- درجة تحقق المعايير لمادة العلوم للمرحلة الابتدائية جميعها كانت كبيرة.

\section{التوصيات (Recommendations)}

في ضوء النتائج التي توصل إليها البحث يوصي الباحثان بما يأتي:

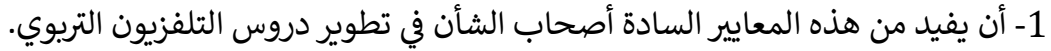

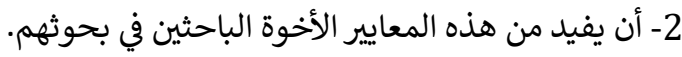

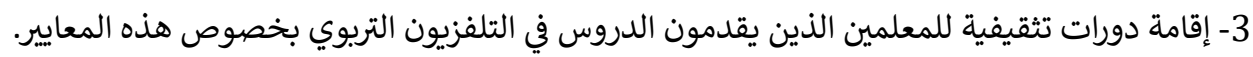
4-أن تكون مدة الدرس متناسبة والفئة المستهدفة. 
(Suggestions) المقترحات

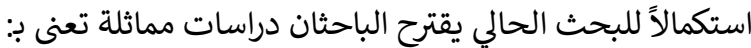

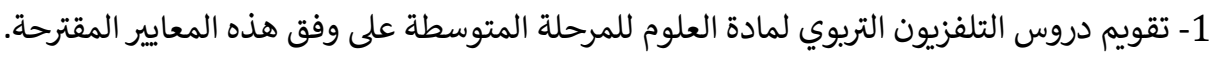

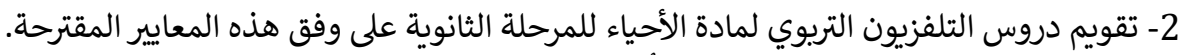

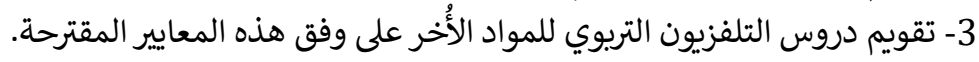

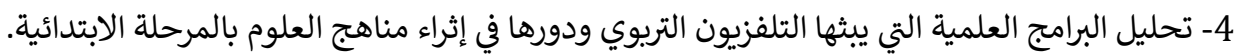

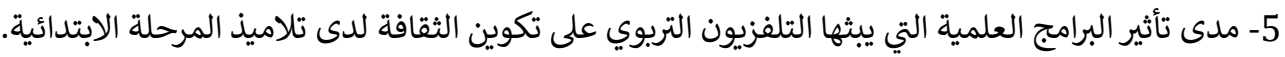

(References) المصادر)

أحمد، سهام حلمي محمد سيد (2009): تقويم البرامج التعليمية الفضائية المتخصصة للعليم الإعدادي بمصر في ضوء بعض إنصاء

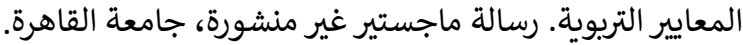

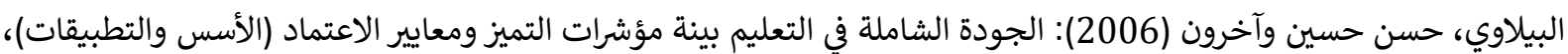
ط1، دار المسيرة للنشر والتوزيع والطباعة، عمان-الأرودن.

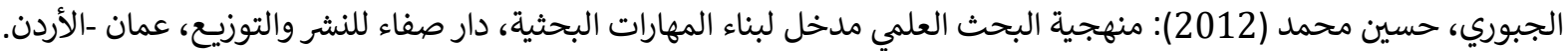

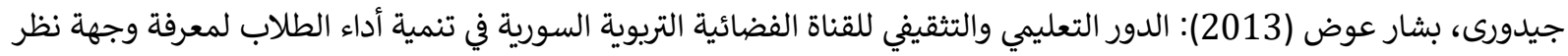

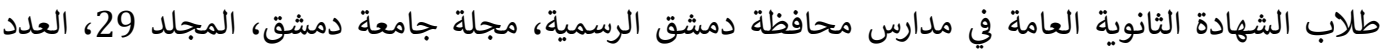

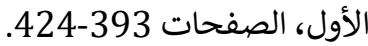

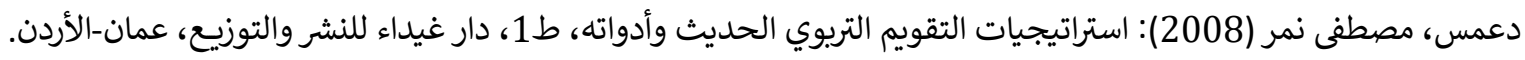

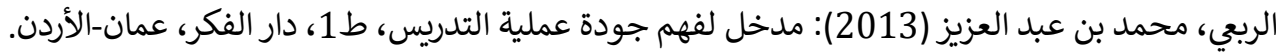

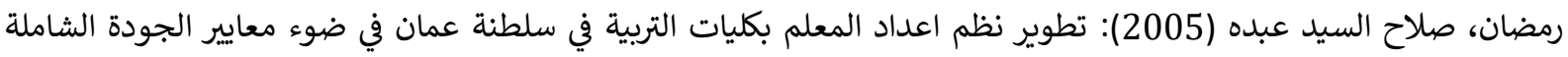

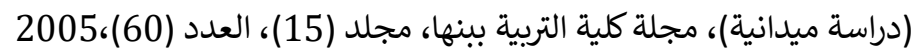

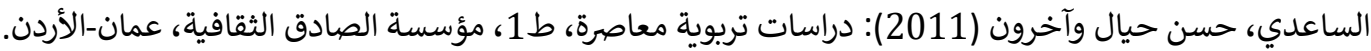

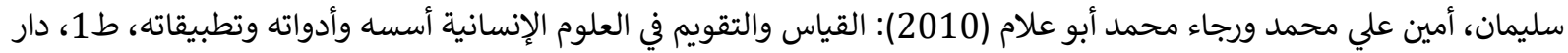

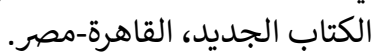

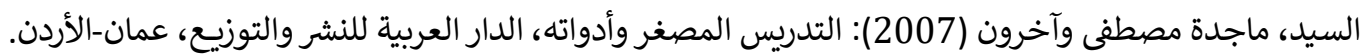

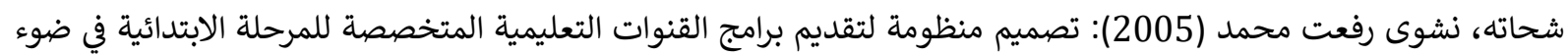

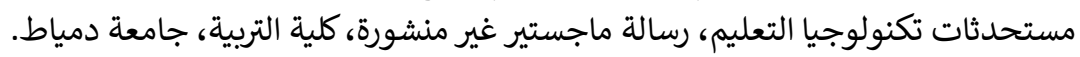

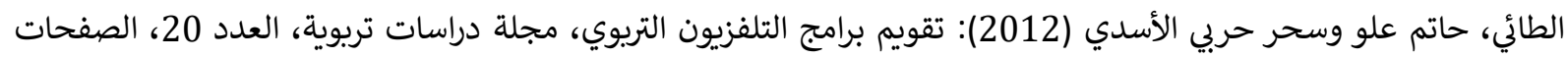
.100-61

عبد الهادي، نبيل (2001): القياس والتقويم التريوي واستخدامه في مجال التدريس الصفي، ط2, دار وائل للنشر والتوزيع، عمان-

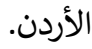

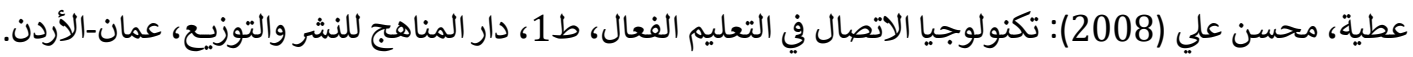

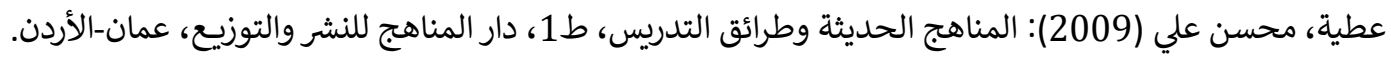

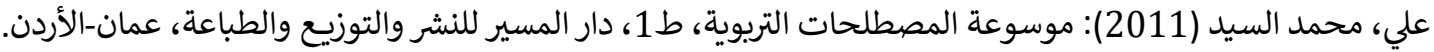

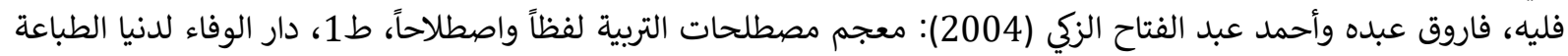
والنشر، الإسكندرية-مصر.

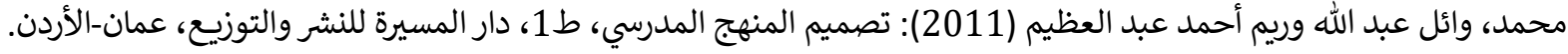

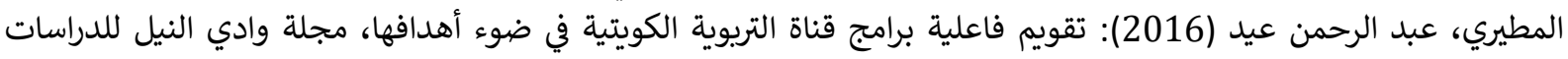

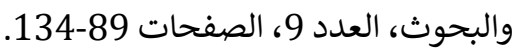

الهاشمي، عبد الرحمن ومحسن علي عطية (2014): تحليل مضمون المناهج الدراسية، ط2، دار صفاء للنشر والتوزيع، عمان-

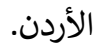


الملاحق (Index)

ملحق (1) استمارة التقويم

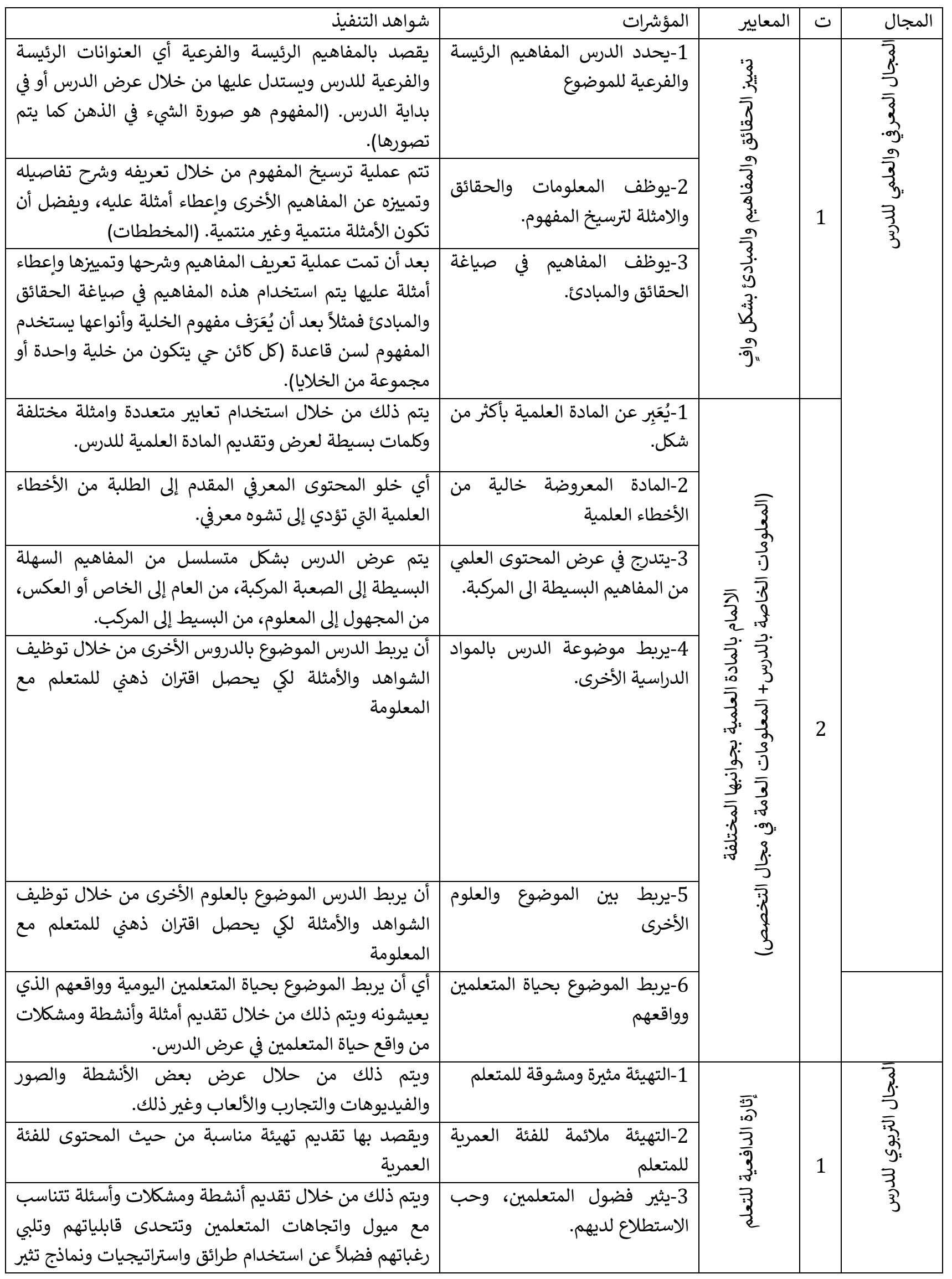


II. International Congress of Humanities and Educational Research (IJHER Congress 2)

\begin{tabular}{|c|c|c|c|c|}
\hline الفضول وحب الاستطلاع لديهم & & & & \\
\hline تقديم التعزيز بأنواعه السلبي والايجابي & 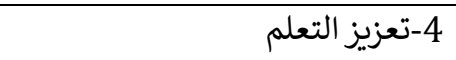 & & & \\
\hline لكسر الجمود والملل يجب عدمب الموق البقاء على وتيرة واحدة في & 5-التغيير في نبرة الصوت & & & \\
\hline 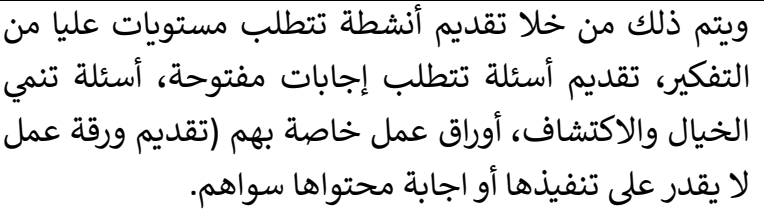 & 1-الاهتمام بالمتميزين. & \multirow{5}{*}{ 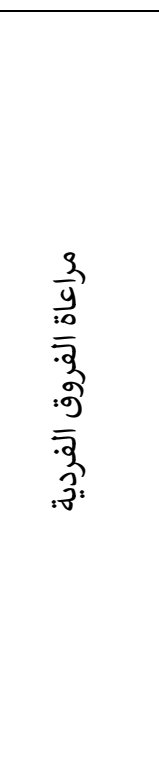 } & \multirow{5}{*}{2} & \\
\hline 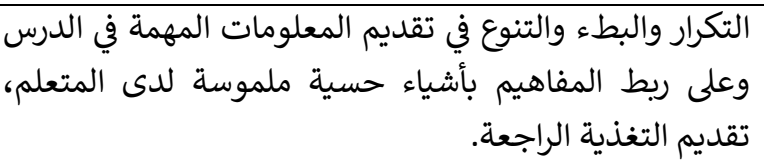 & 2-رعاية المتأخرين دراسياً. & & & \\
\hline أن المادة المقدمة الدرس التباين والفروقات والمتيجيات والمتبعة والاسئلمينة المطروحة حيثة & 3-مراعاة التباين بين المتعلمين. & & & \\
\hline تحديد وقت الدرس بما لا يؤدي إلى ملل المتعلمين وعزوفهم & العمرية المدة الدرس مناسبة للفئة & & & \\
\hline موضوع الدرس. أيقدم الدرس تغذية راجعة بأنواعها المختلفة عن & 5-التغذية الراجعة & & & \\
\hline أبداع الخلق يقوم الدرس بالتأكيد على عظمة الخالق وقدرته في & 1-تقدير عظمة الخالق & \multirow{5}{*}{ 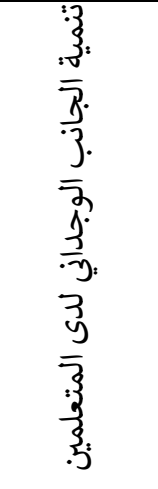 } & \multirow{5}{*}{3} & \\
\hline 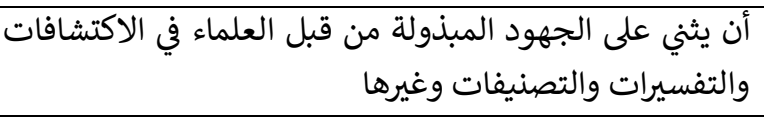 & 2-تثمين جهود العلماء & & & \\
\hline غرس القيم الدينية والأخلاقية والوطنية في سلوك الطلبة & 3-غرس القيم والمبادئ السامية & & & \\
\hline من خلال التأكيد على المناسبات الوطنية والدينية والانتماء & 4-تعميق روح المواطنة & & & \\
\hline توجيه المتعلمين وتدريبهم على السلوكيات التي تحافظ على & 5-المحافظة على النظام البيئي & & & \\
\hline الرياضة المتعلمين على ممارسة العادات الصحية مثل مماسة & الوقاية من الأمراض والأوبئة إيجابية نحو & \multirow{4}{*}{ 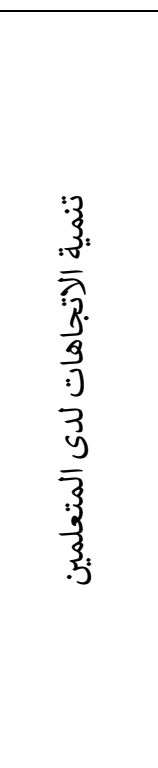 } & \multirow{4}{*}{4} & \\
\hline ماسثة الرياضة بأنواعها المختلفة ممارسة العادات الصكل الصحية من والممارسات خلال & 2-ينمي العادات الصحية السليمة إيجابية نحو & & & \\
\hline تبصير المتعلمين بأهمية الحفاظ على نظافة الجسد & المحافظة على النظافة إيجابية نحو & & & \\
\hline التحدث بها والتأكيد على أهميتها العفحة دائماً وحث المتعلمين على & 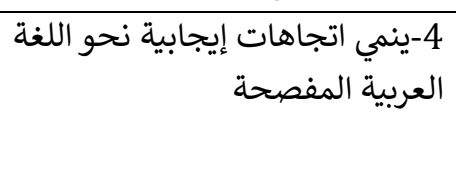 & & & \\
\hline يحدد أهداف الدرس ويعرضها على الطلبة & 1-يحدد الأهداف ويعرضها. & $.3 \cdot 9 \cdot \overline{7}$ & 1 & p \\
\hline
\end{tabular}




\begin{tabular}{|c|c|c|c|}
\hline ويتم من خلال والحوار حول الأهداف المعروضة. & 2-يناقش الأهداف المعروضة. & & \\
\hline مثل المشروع والاستط المفاهيمية وجدول الموجه وغرها قدر الإمكانم الذاتي والتعلم & 1 1-يستخدم التعض النشط استراتيجيات & \multirow{6}{*}{$\frac{\sqrt[3]{3}}{3}$} & \multirow{6}{*}{2} \\
\hline أي أن يركز الدرس على مهارات التفكير الناقد وينميها. & 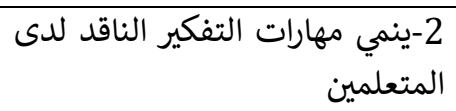 & & \\
\hline 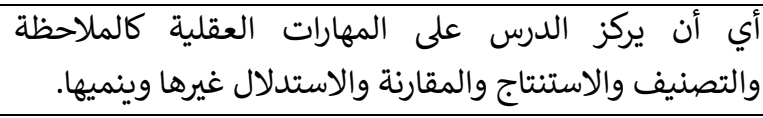 & 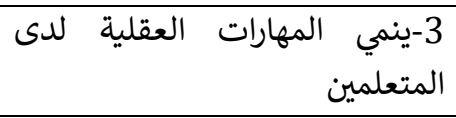 & & \\
\hline والطلاقة والمرونة غيرها وينميها. & 4-ينمي مهارات التفكير الإبداعي & & \\
\hline 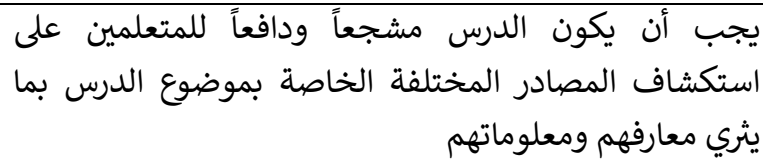 & 5-يحفز المتعلمين على البحث & & \\
\hline 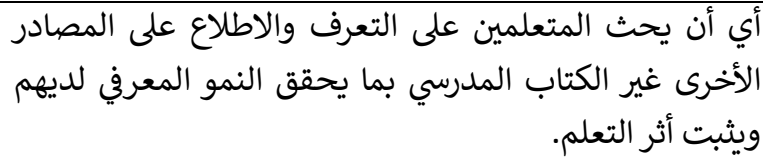 & 6-يحفز المتعلمين على الرجوع الى الى المصى & & \\
\hline تطبيقية، تبئلة أو مشكلة، تقاربية، وغيرها) مراعياً فيها أبعاد الأهداف، تحريرية، & 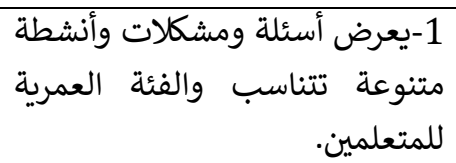 & \multirow{3}{*}{ 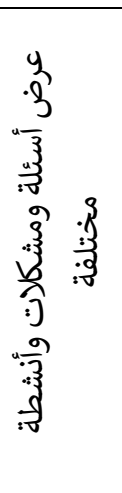 } & \multirow{3}{*}{3} \\
\hline 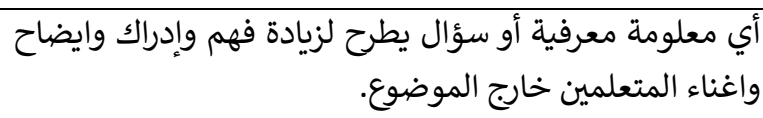 & للمتعلمين. & & \\
\hline 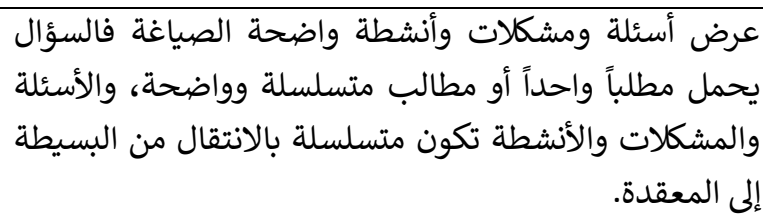 & 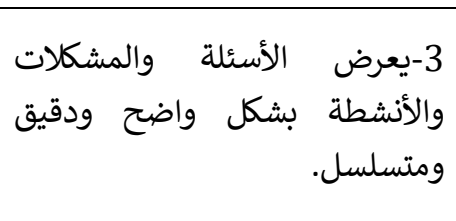 & & \\
\hline 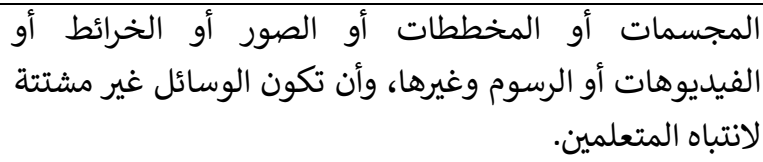 & 1 البوريتوعة. & 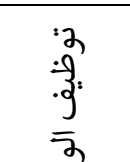 & \\
\hline 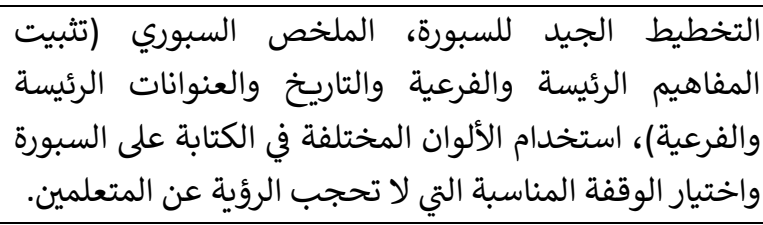 & 2-يستعمل السبورة بطريقة فاعلة. & $\begin{array}{l}\frac{3}{3} \\
\frac{3}{3} \\
\overline{3} \\
3 \\
3 \\
3 \\
3\end{array}$ & 4 \\
\hline لتثتبيت أثر التعلم يجب أن يكلف المتعلمين بواجبات منزلية & دراسية إلكترونية. & 可 & 5 \\
\hline
\end{tabular}


II. International Congress of Humanities and Educational Research (IJHER Congress 2)

\begin{tabular}{|r|r|r|r|r|}
\hline & & & \\
\hline \\
\hline
\end{tabular}


THE CONTRIBUTIONS OF PHYSICS TO THE RISE AND DEVELOPMENT OF PHILOSOPHY AT THE OPENING OF THE MODERN ERA

Salima GAID 


\title{
THE CONTRIBUTIONS OF PHYSICS TO THE RISE AND DEVELOPMENT OF PHILOSOPHY AT THE OPENING OF THE MODERN ERA
}

\author{
Salima GAID ${ }^{1}$
}

\begin{abstract}
:
Modern Western philosophy is the third stage in the history of philosophy, and it begins at the beginning of the seventeenth century with Descartes. The reason why historians of philosophy have classified this philosophy in a third stage is that it represented a new type of philosophizing completely different from the philosophical pattern that prevailed in the middle Ages. The truth is that the rise of this new style of philosophizing did not come out of nothing, but it rather emerged from a set of objective reasons, including the religious reform and scientific advance or renaissance, that various sciences have witnessed; mainly physics in the forefront. Physics has known amazing developments thanks to great scientists; the most famous of them is Galileo, who is credited with establishing modern physics. The rise of modern physics led directly to the emergence of modern philosophy, and the developments that physics will know after the Renaissance will also be directly reflected in the development of philosophy.

This point in particular is what we would like to study in this research paper, we will seek to demonstrate the close relations between philosophy and physics at the beginning of the modern era, to show through them the contributions of physics to the rise of modern philosophy, and its aftermath developments. These contributions appear in the fact that physics determines the subject of philosophy, its method in particular, and its identification of the various issues that it will raise, as well as the various theories and doctrines that it will construct to answer them.
\end{abstract}

Key words: Mechanics, Materialism, Mechanism, Atomism, Expérimental Method, Empiricism.

http://dx.doi.org/10.47832/ijhercongress2-4

${ }^{1}$ High School of Teachers, Algeria, salima.gaid@gmail.com, https://orcid.org/0000-0003-4831-997X 


\section{إسهامات الفيزياء في نشأة وتطور الفلسفة في مطلع العصر الحديث}

\section{سليمة قايد 2}

الملخص:

تعد الفلسفة الغربية الحديثة المرحلة الثالثة من تاريخ الفلسفة، وهي تبدأ مطلع القرن السابع عشر مع ديكارت. والسبب الذي

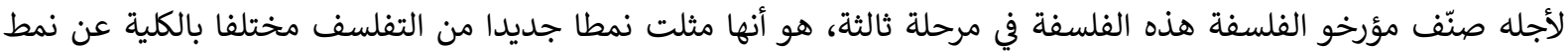

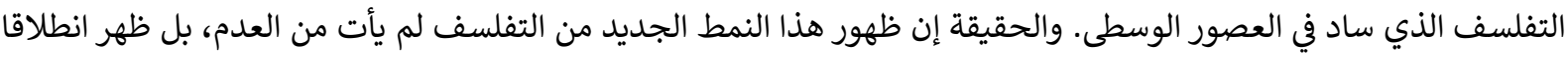

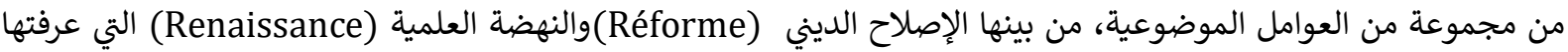

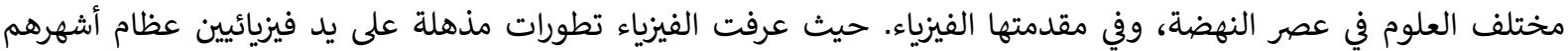

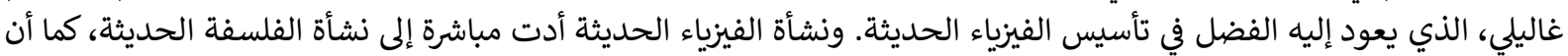

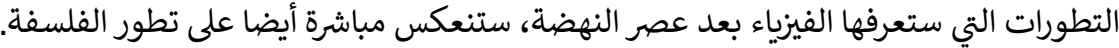

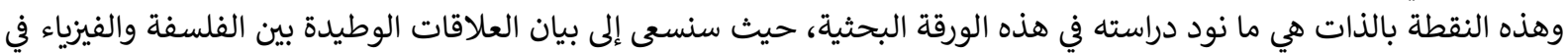

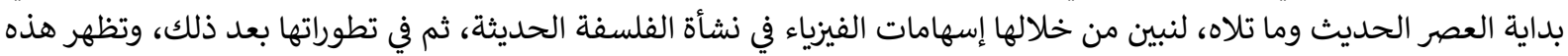

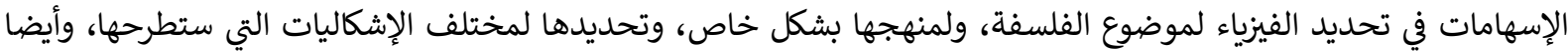

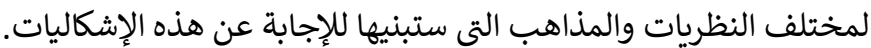
الكلمات المفتاحية: الميكانيكا، المذهب المادي، النزعة الآلية، المذهب الذياتيات الذري، المنهج التجريي، المذهب التجريي. 
عرفت الفيزياء في عصر النهضة ثم في العصر الحديث طفرة نوعية، نقلتها من الفيزياء الأرسطية الكيفية التي تعد ميتافيزيقا

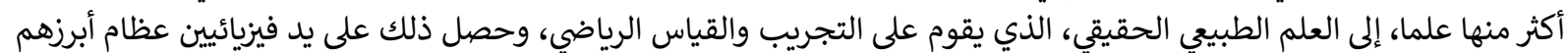

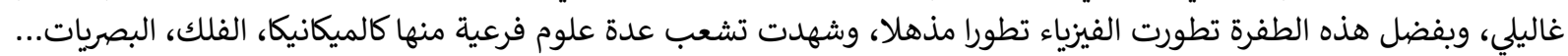

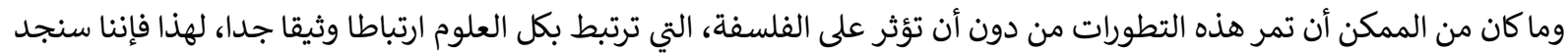

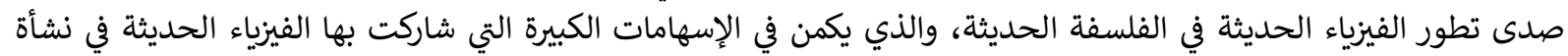

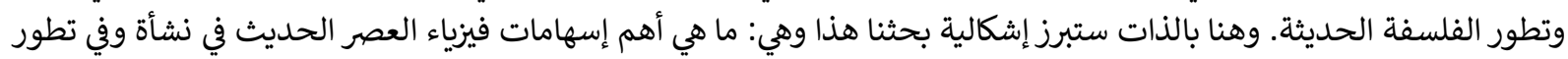

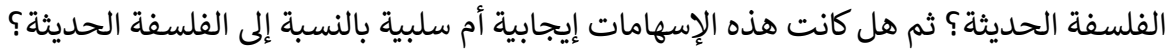

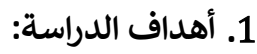

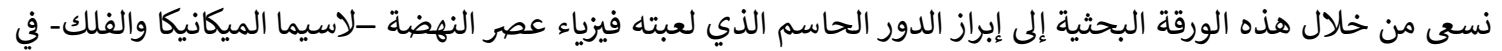

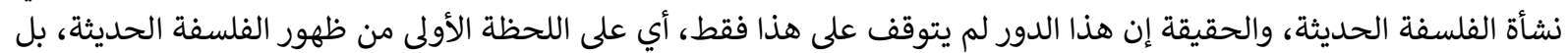

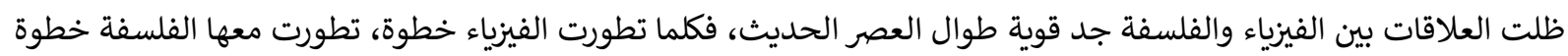

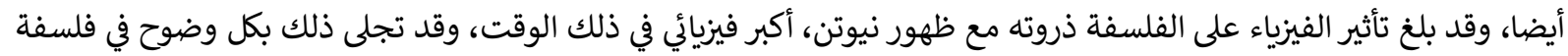
ديفيد هيوم، الذي أراد أن يكون نيوتن الفلسفة أفئه

2. إسهامات فيزياء عصر النهضة في نشأة الفلسفة الحديثة:

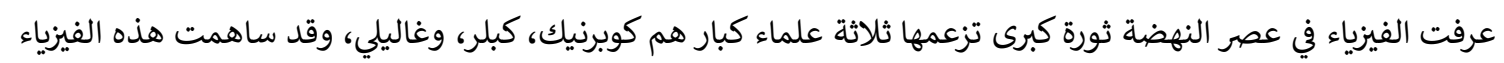

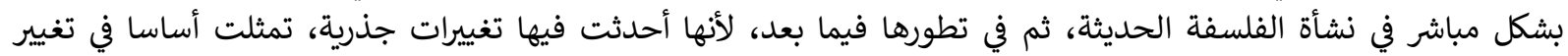
موضوعها ومنهجها على السواء، كما سنشرحه الآن.

1.2. تغير موضوع الفلسفة:

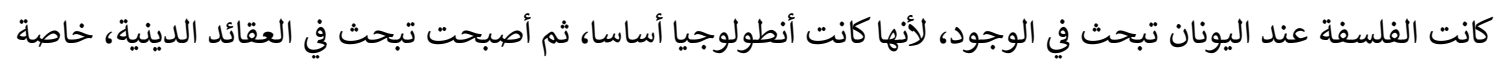

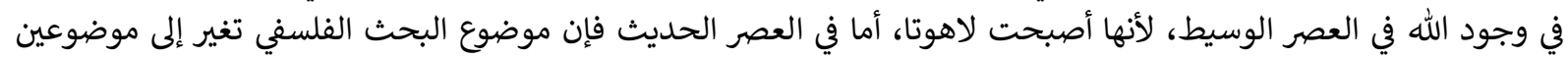

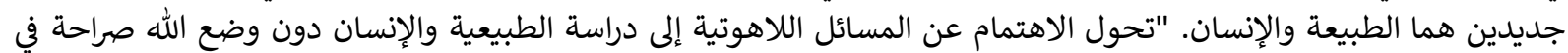

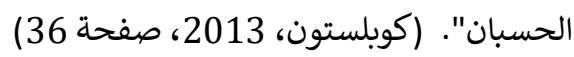

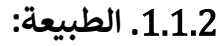

فكف فلاسفة العصر الحديث منذ ديكارت على دراسة الطبيعة، التي أصبحت موضوعا رئيسيا للفلسفة الحديثة، وكان

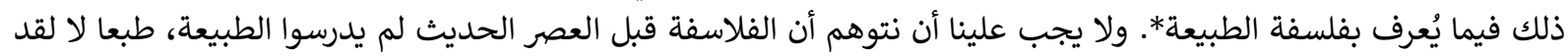

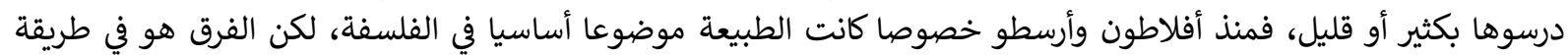

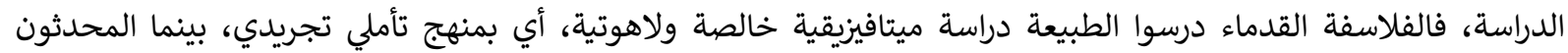

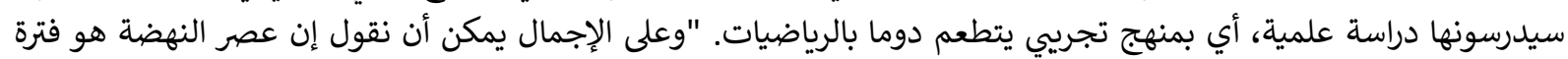

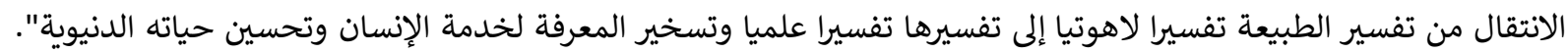

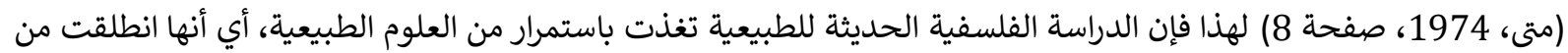

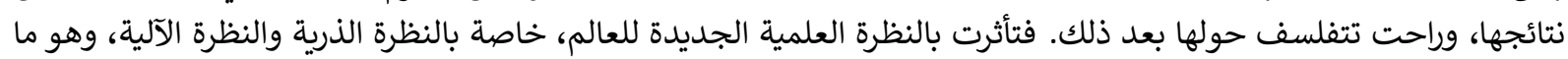
سنعود لشرحه لاحقا.

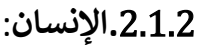

ثاني موضوع اهتمت الفلسفة الحديثة بدراسته هو الإنسان، وهو أيضا موضوع لم يكن مجان إنهان إنهولا تماما في الفلسفات السابقة،

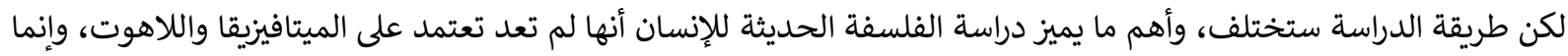

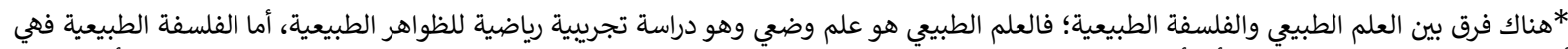

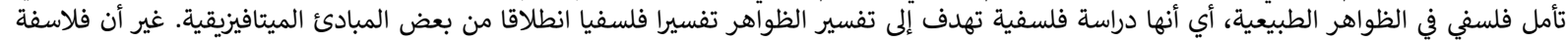

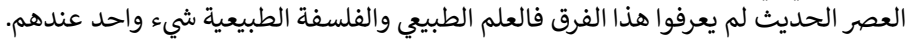


اعتمدت على العلوم الطبيعية المختلفة -والرياضيات أيضا- حيث ستتحول نظرة الإنسان لنفسه من نظرة ميتافيزيقية لاهوتية إلى إلى

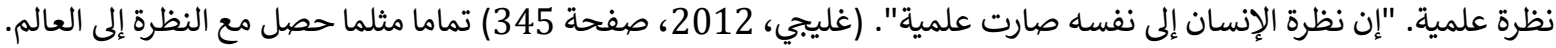

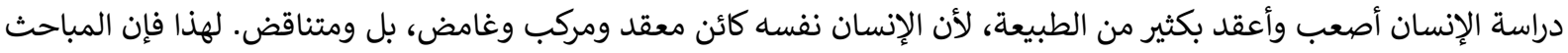

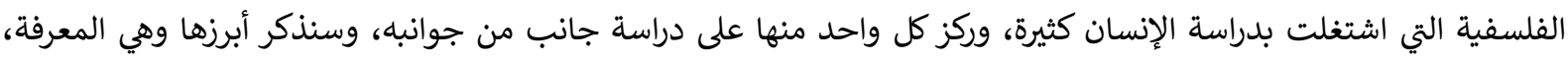

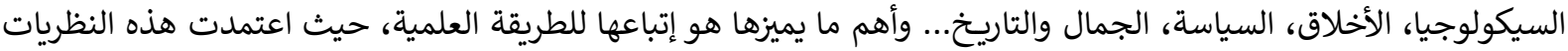

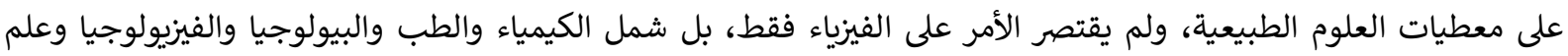
النفس التجرييي... كما سنراه فيما بعد.

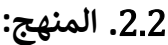

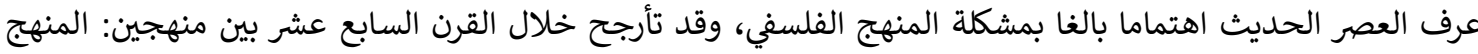

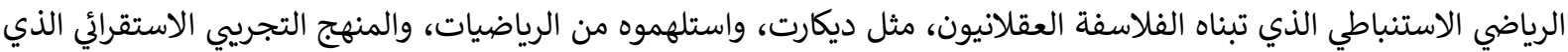

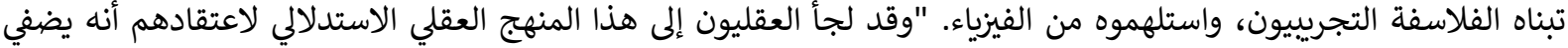

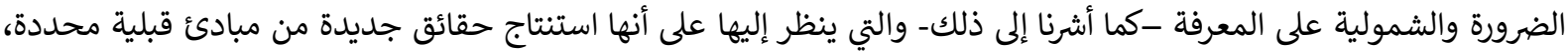

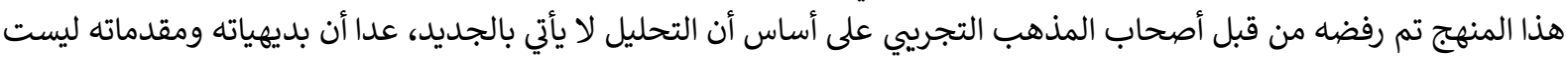

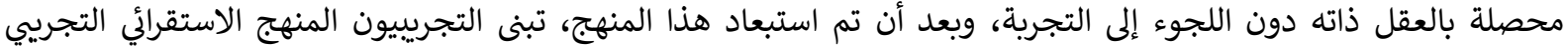

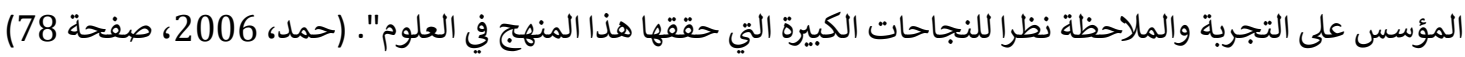

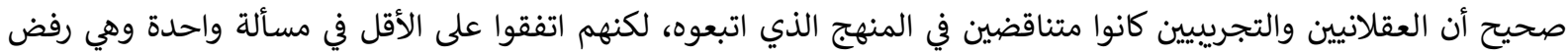

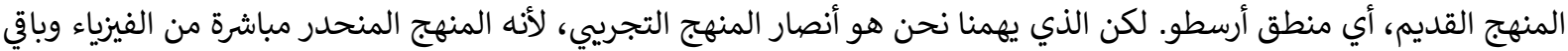

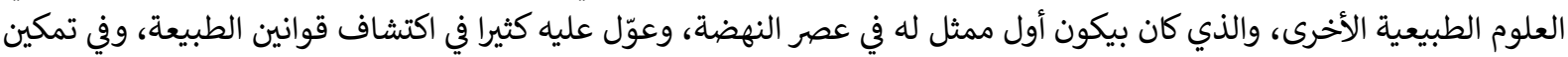

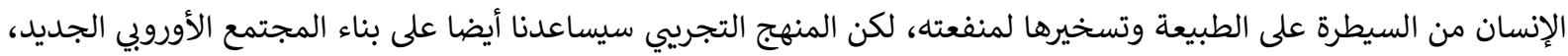

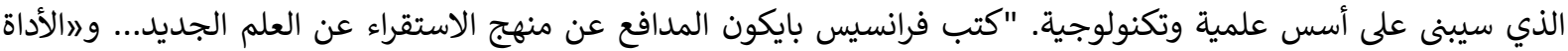

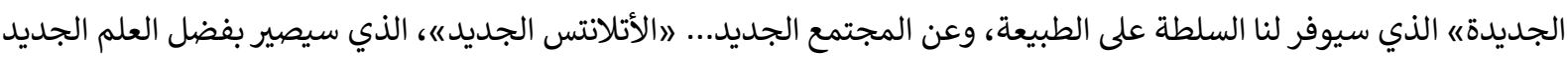

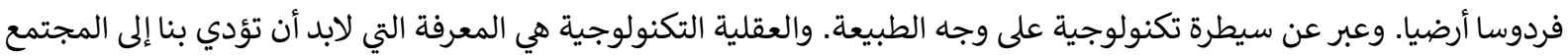

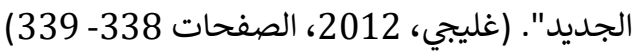

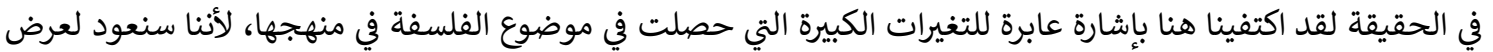

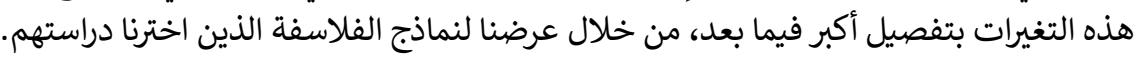

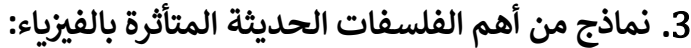

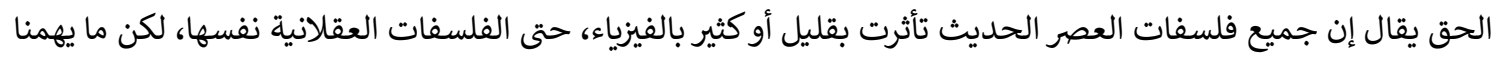

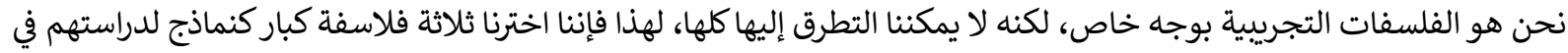

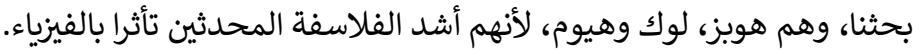

\section{3. فلسفة هويز (المذهب المادي- الآلي):}

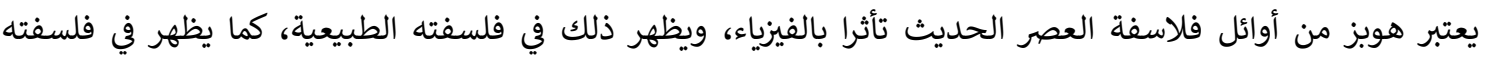

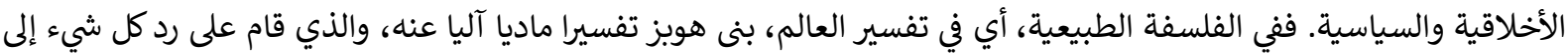

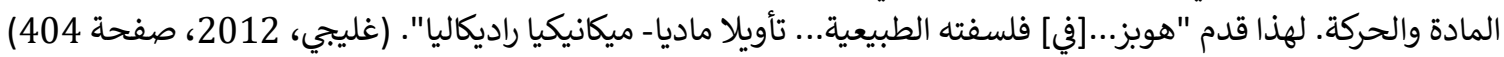

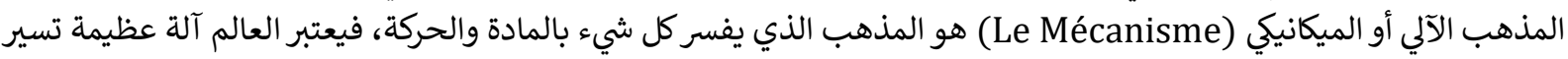

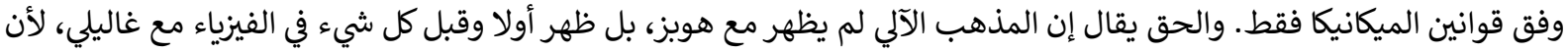

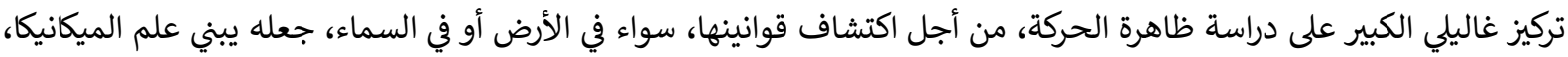

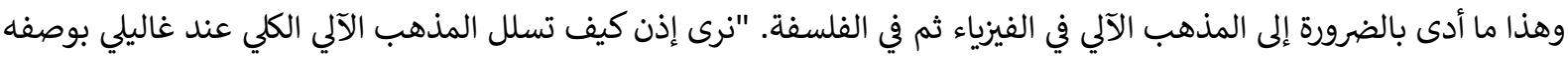

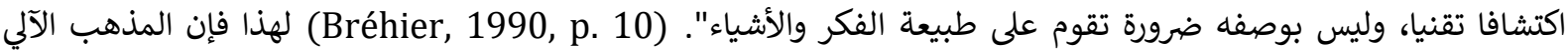

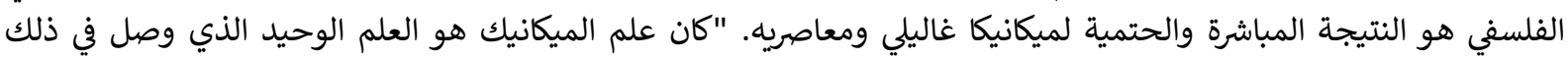

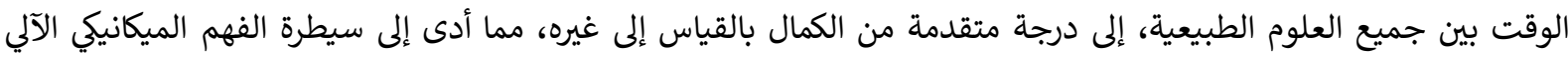

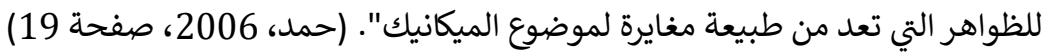




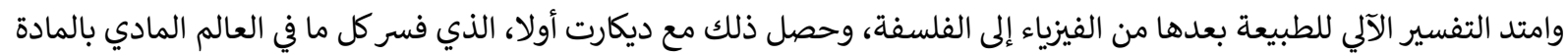

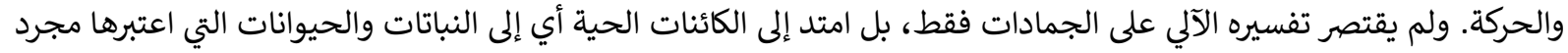

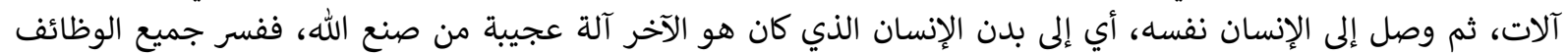

العضوية للإنسان بالمذهب الآلي.

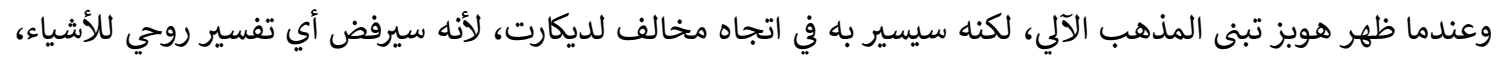

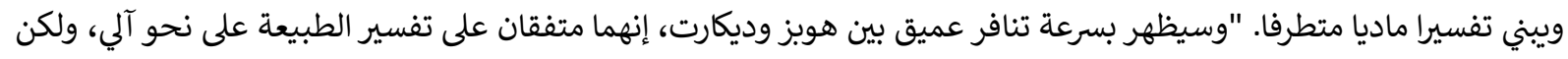

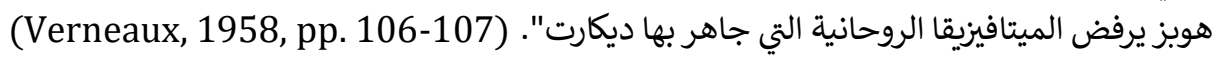

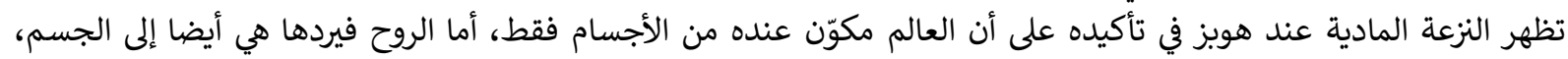

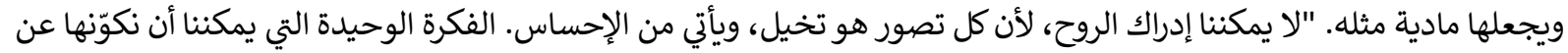

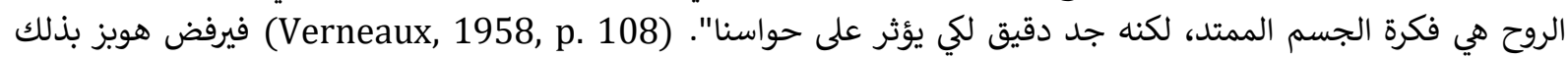

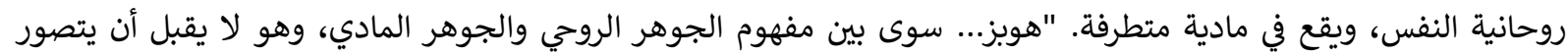

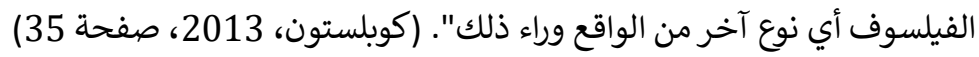

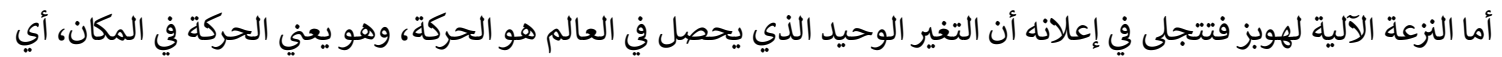

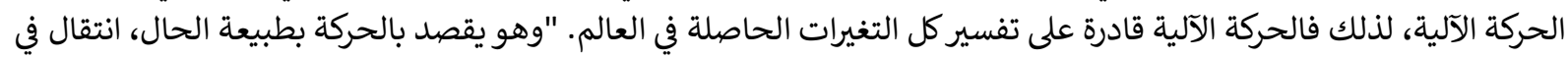

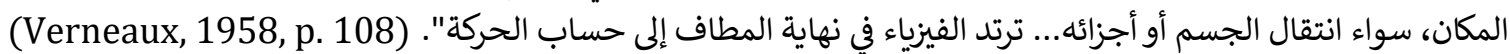

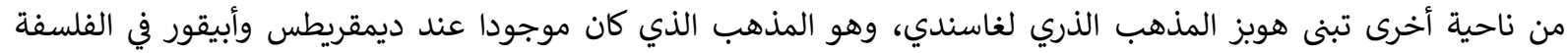

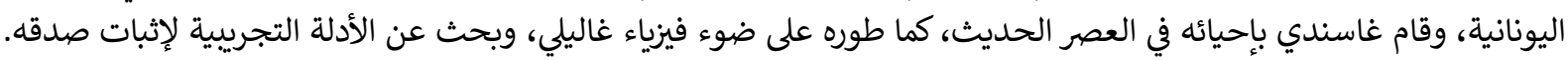

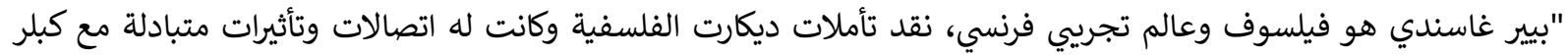

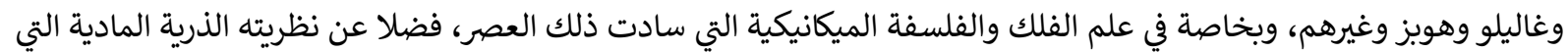

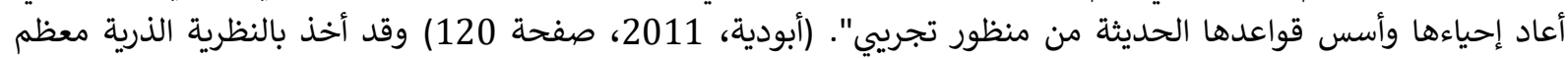

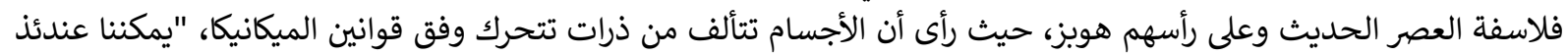

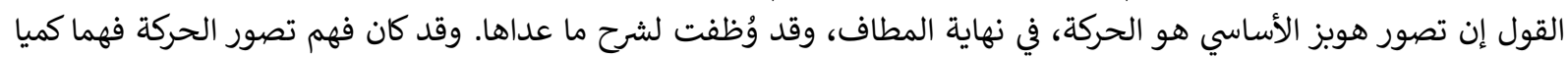

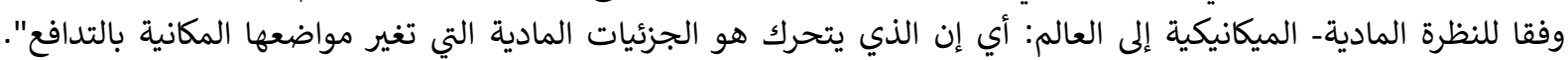

(غليجي، 2012، صفحة 404)

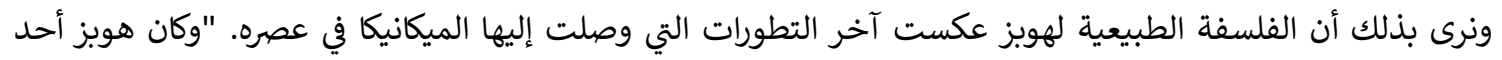

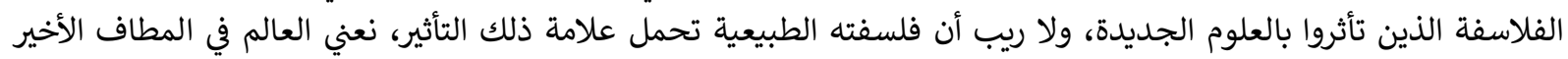

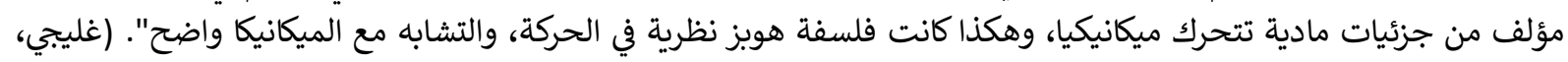

2012، صفحة 393 منيات مادية

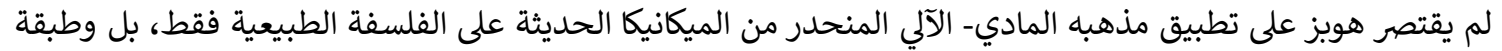

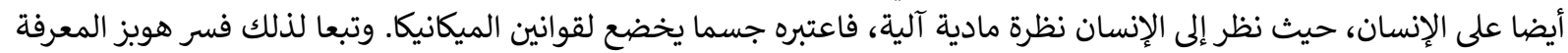

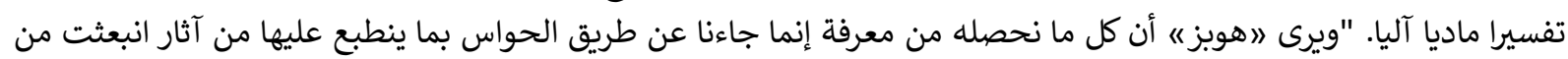

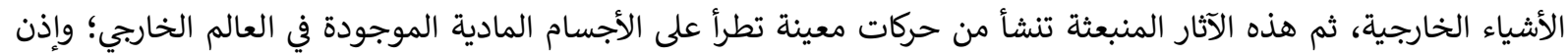

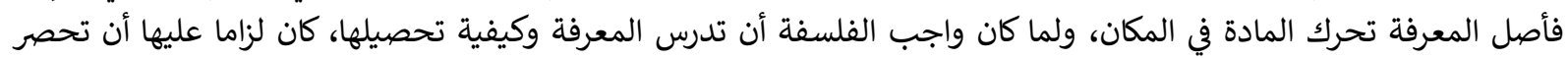

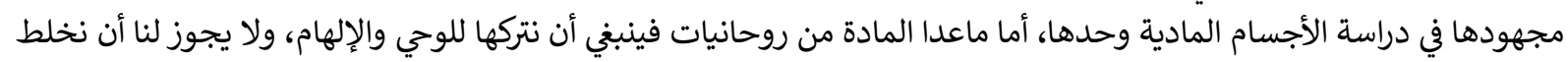

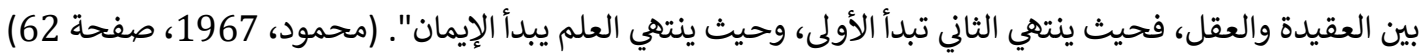

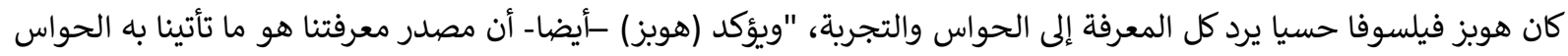

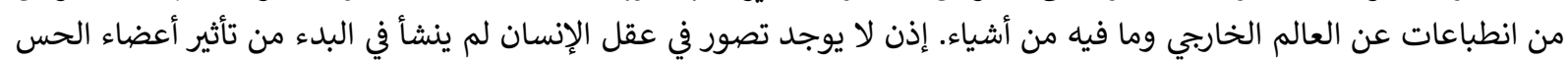

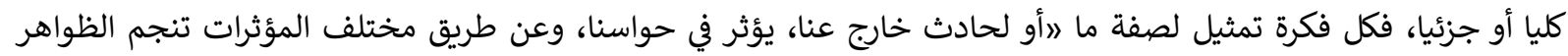

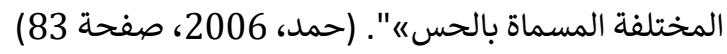

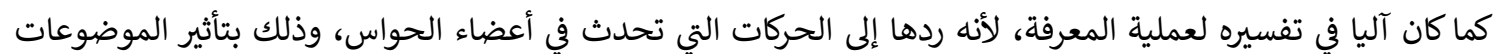

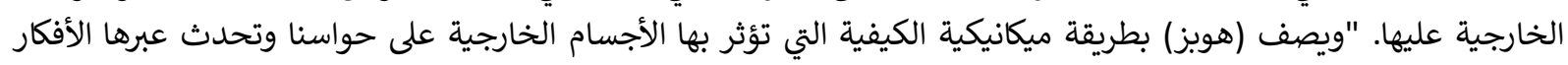

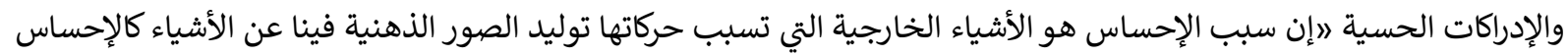

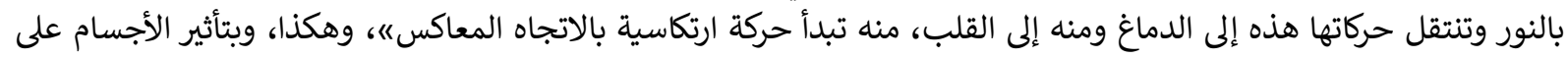

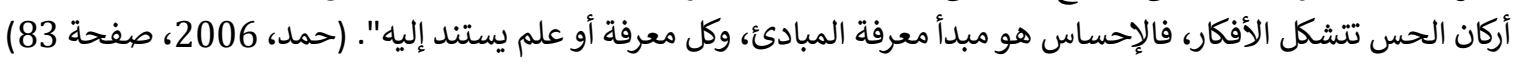




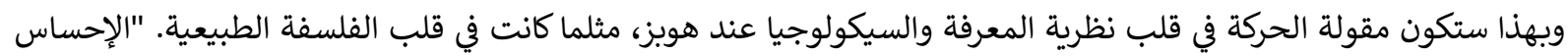

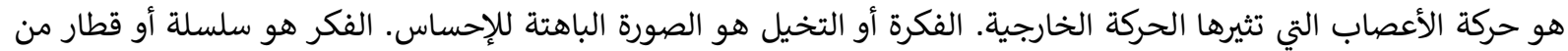

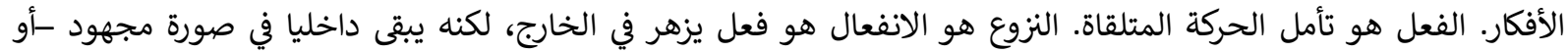

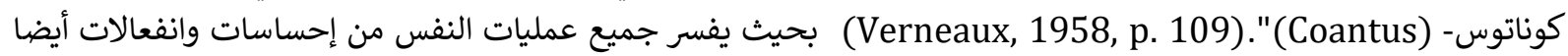

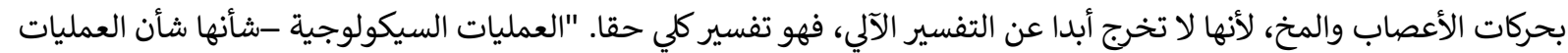

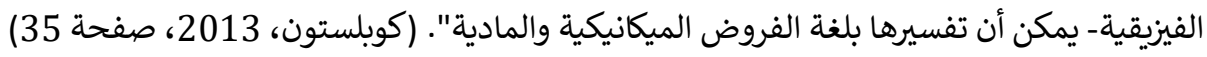

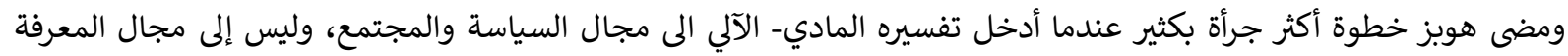

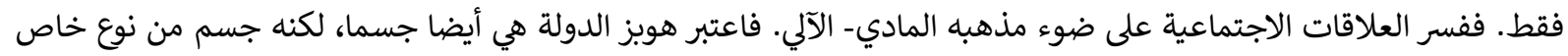

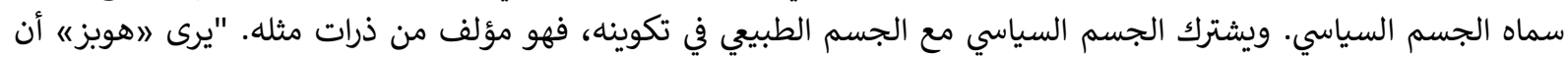

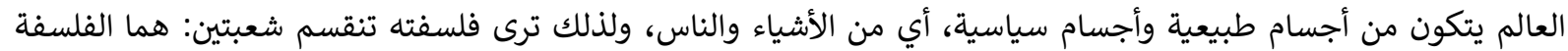

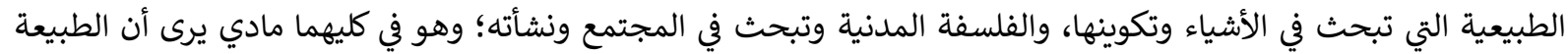

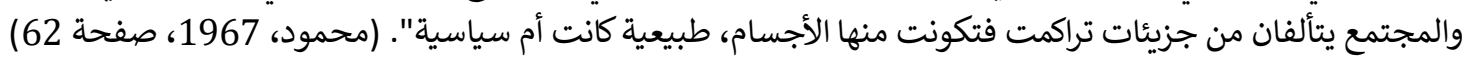

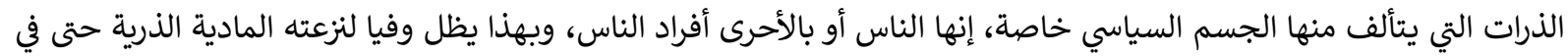

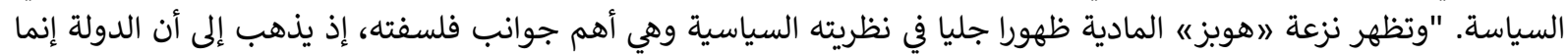

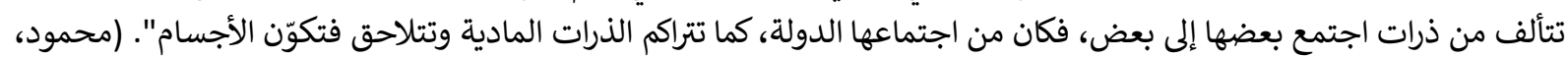

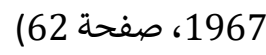

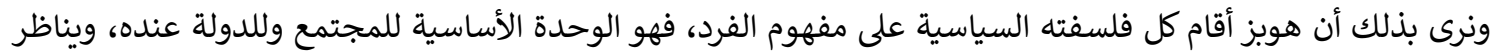

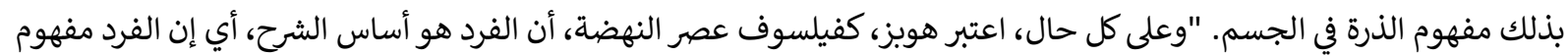

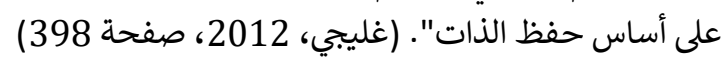

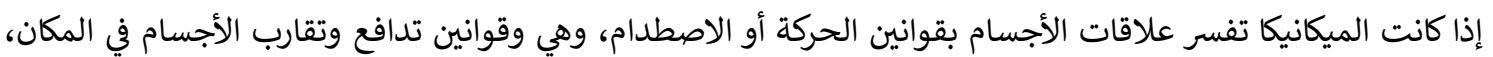

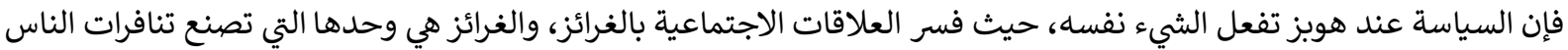

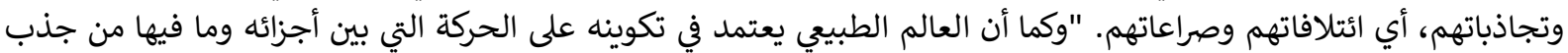

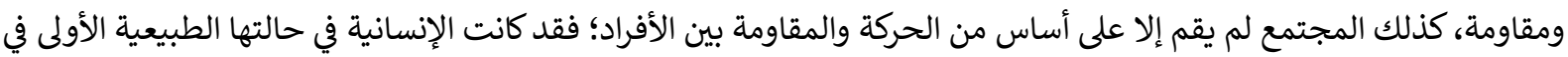

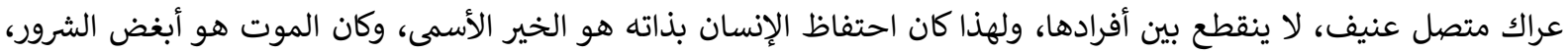

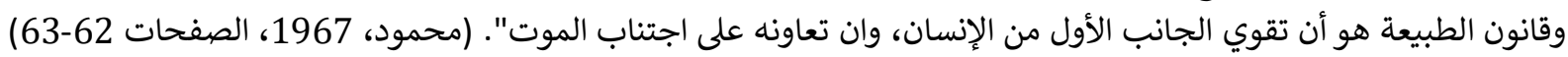

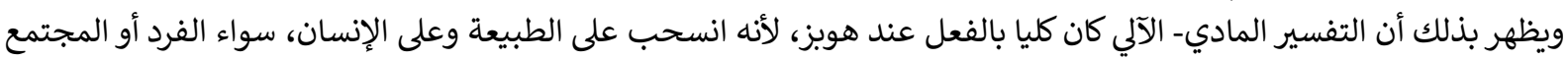

\section{3. جون لوك (المذهب التجريبي المعتدل):}

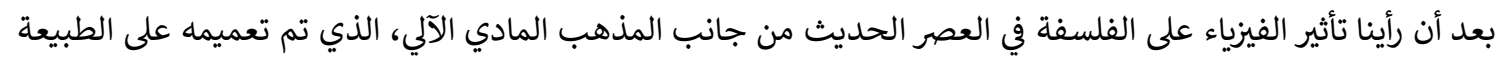

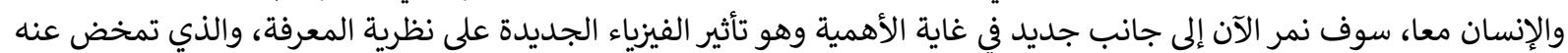

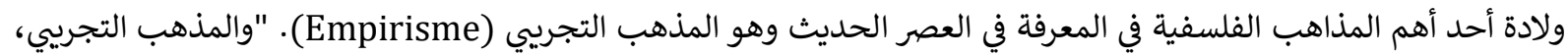

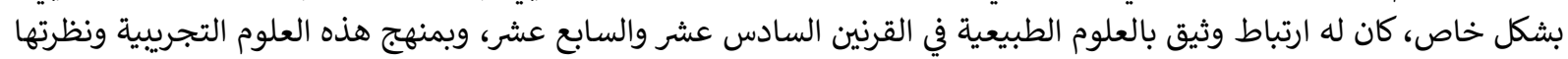

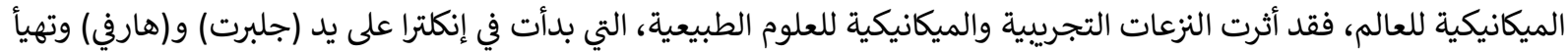

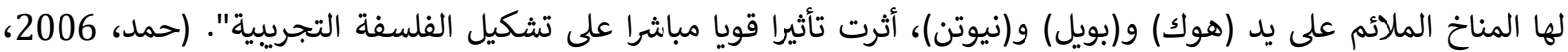

صفحة 80)

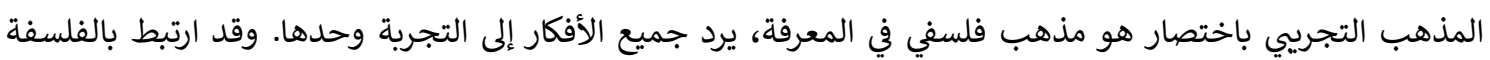

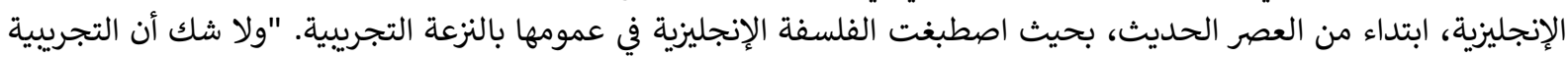

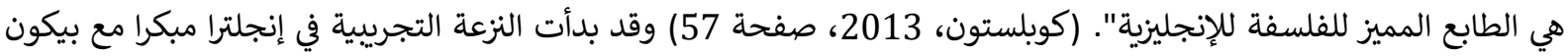

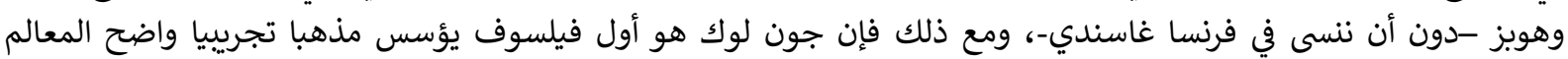

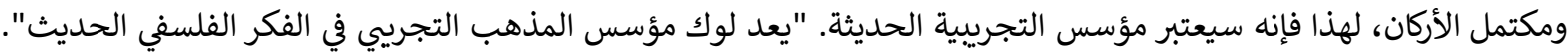

(عباس، 1996، صفحة الاركان، لهذانه

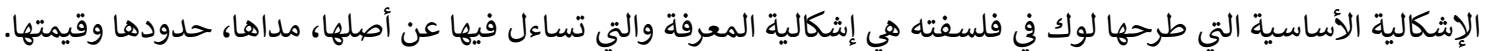

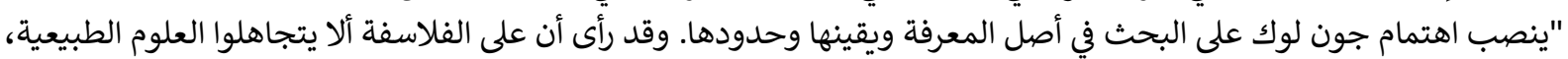




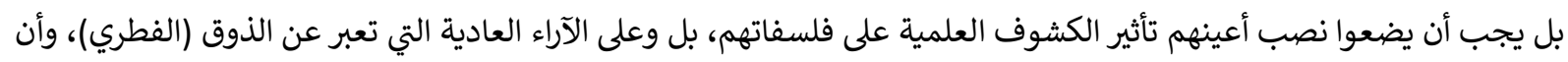

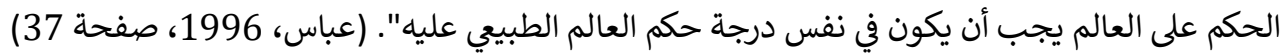

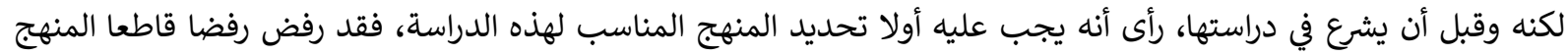

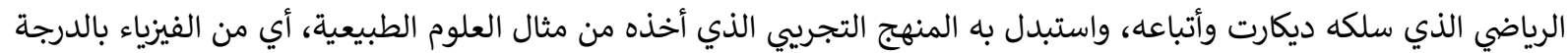

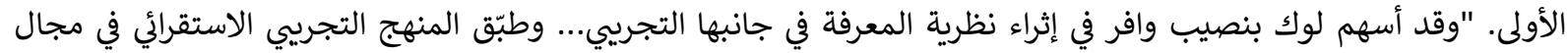

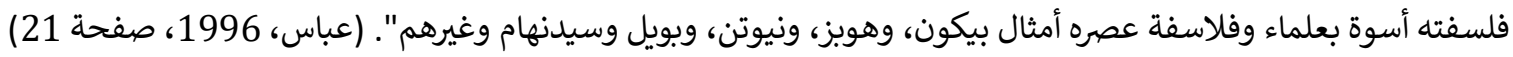

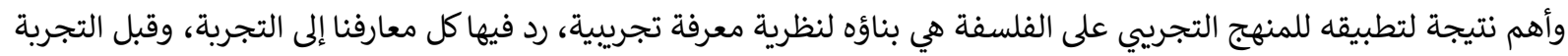

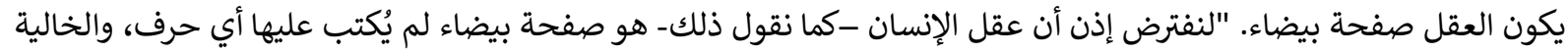

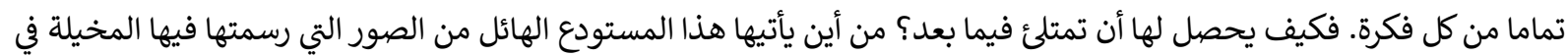

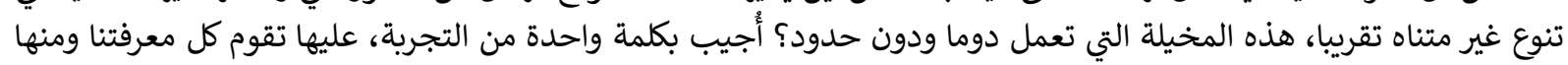

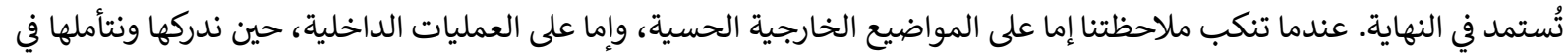

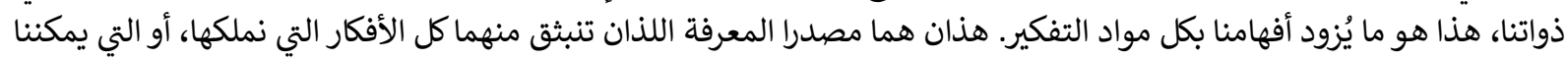

الحصول عليها بصفة طبيعية". (Locke, 2004, p. 74)

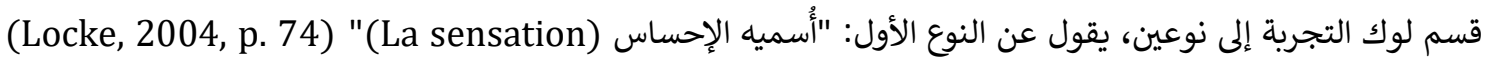

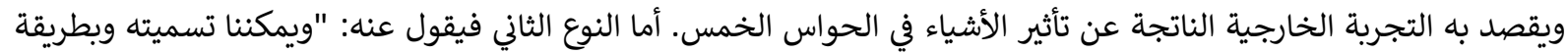

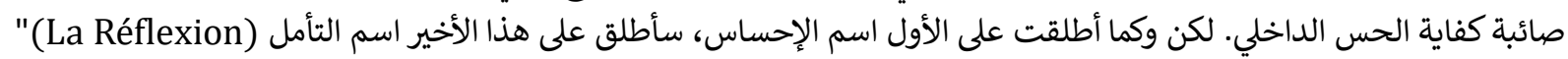

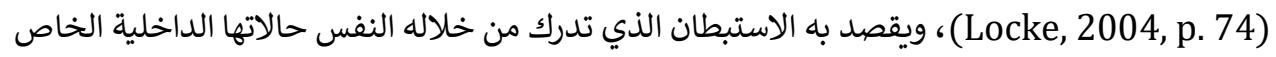

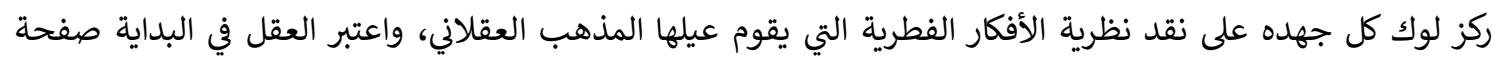

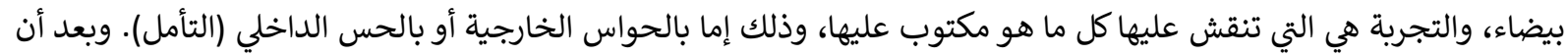

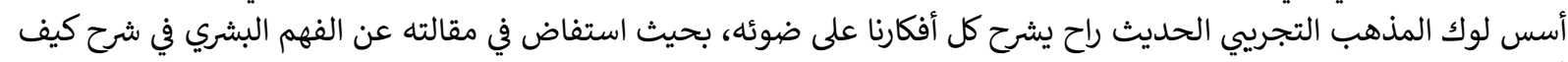

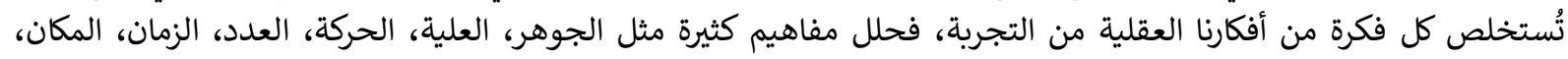

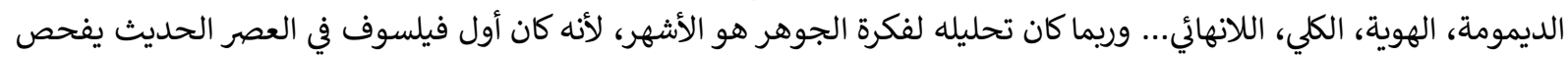

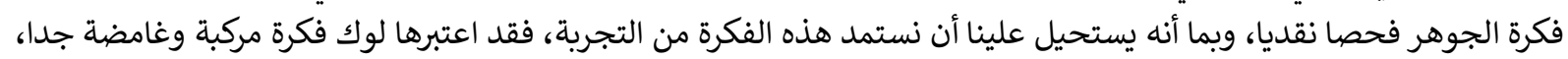

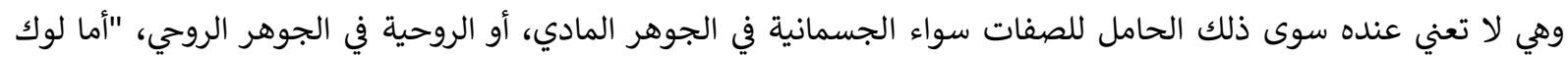

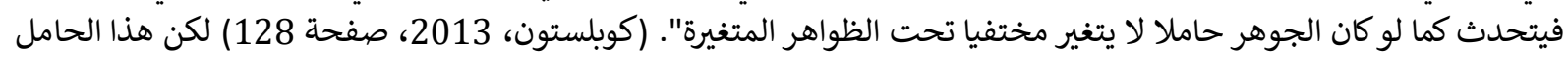

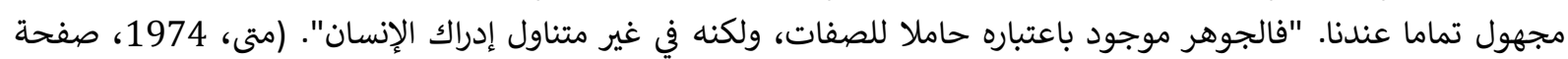

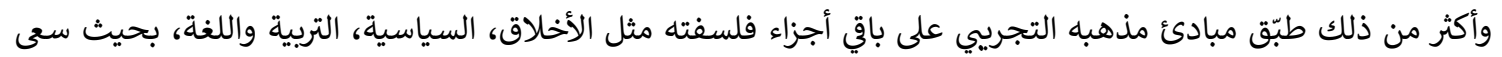

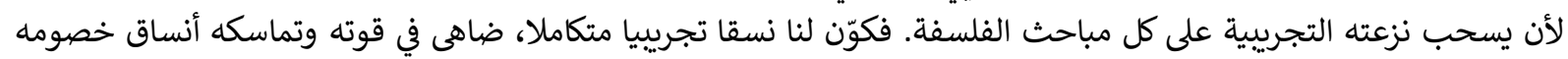

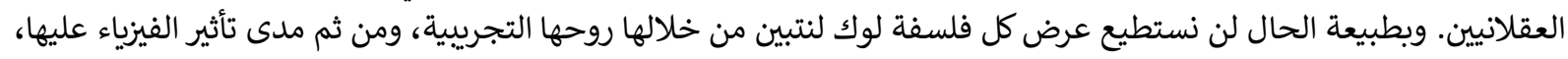
ل لهذا اكتفينا بالإشارة إليها فقط.

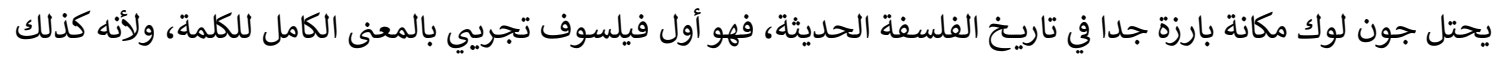

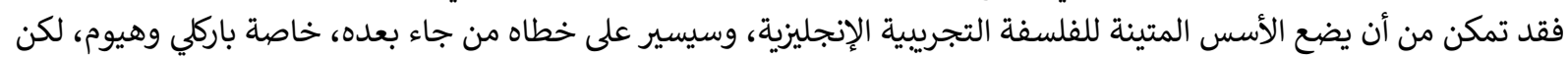

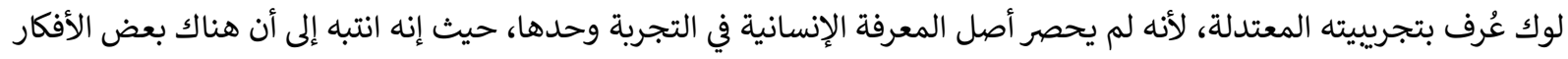

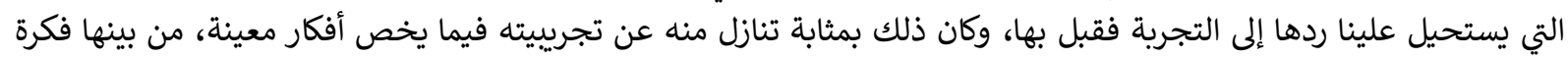

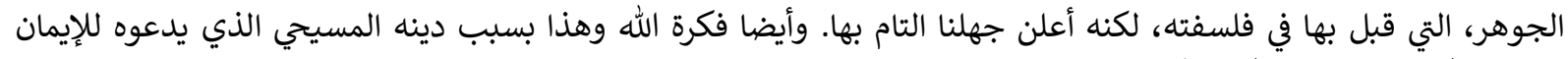

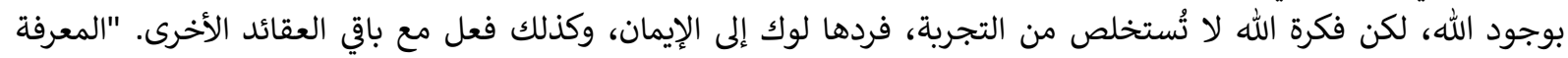

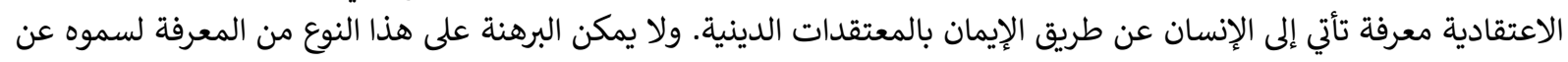

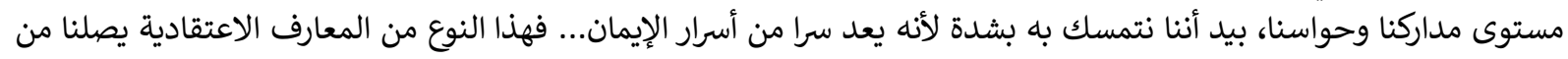

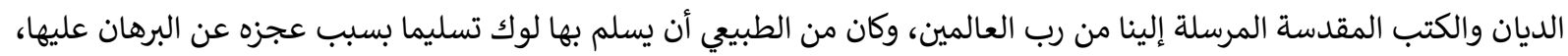

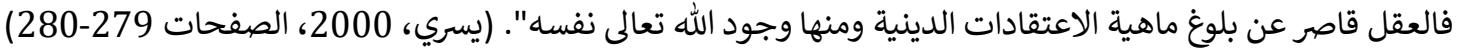

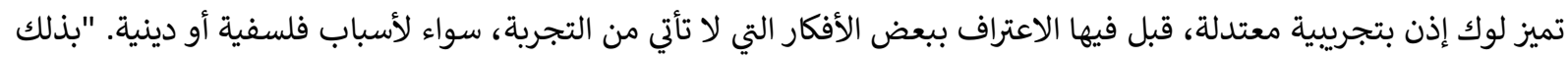

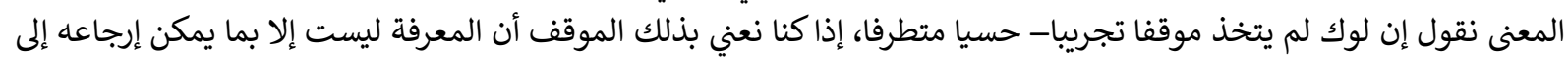

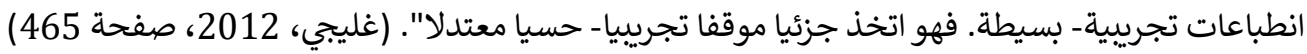


سار ديفيد هيوم في الطريق الذي رسمه أسلافه الإنجليز، لوك وباركلي خصوصا، فاتبع المذهب التجرييي، لكنه طوره إلى إلى

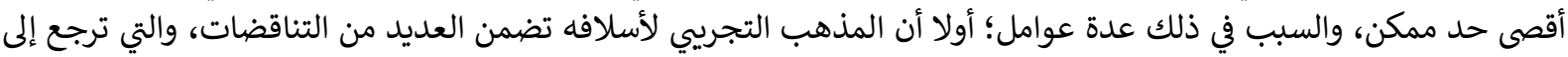

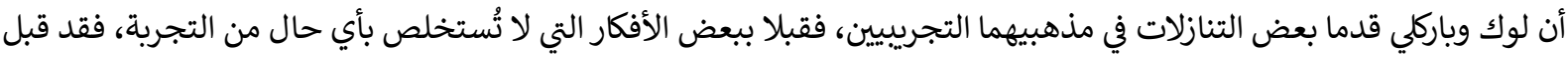

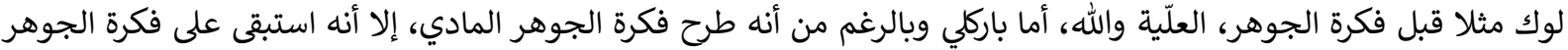

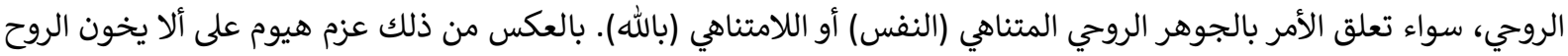

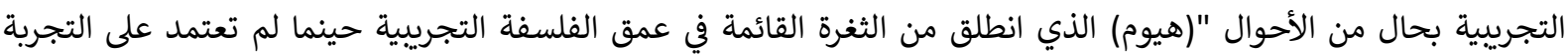

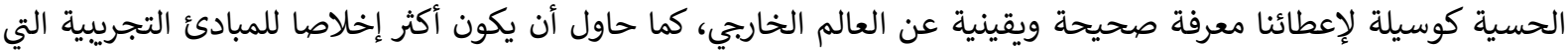

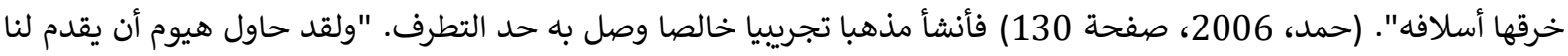

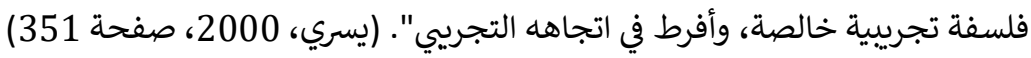

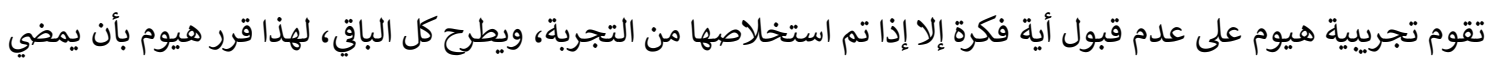

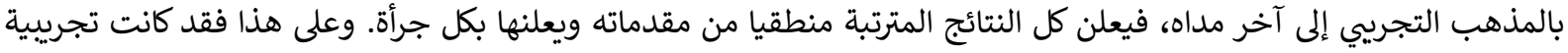

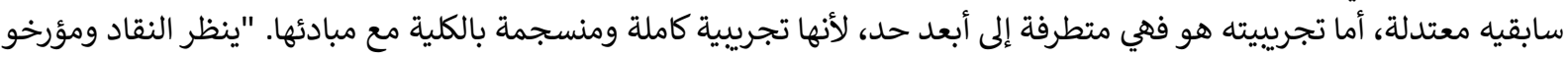

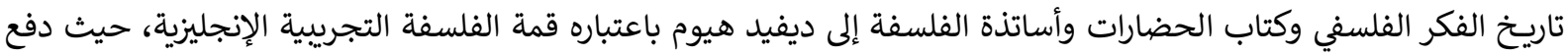

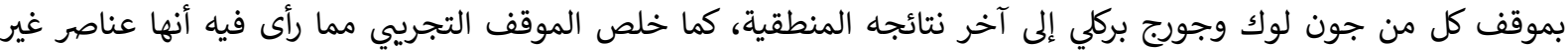

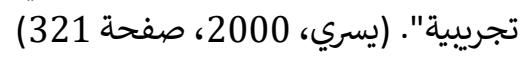

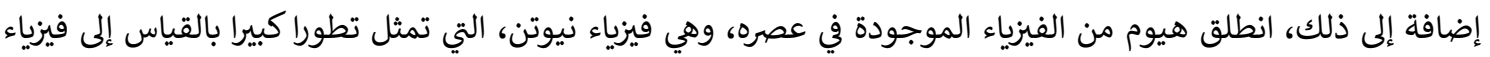

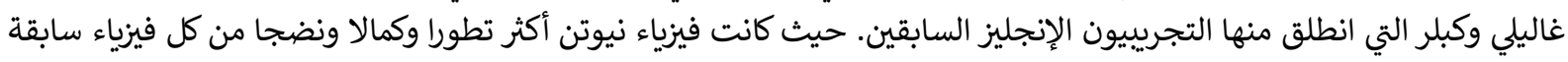

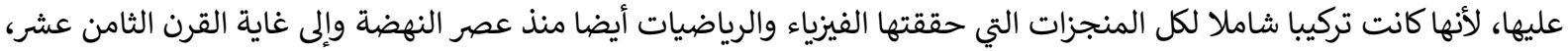

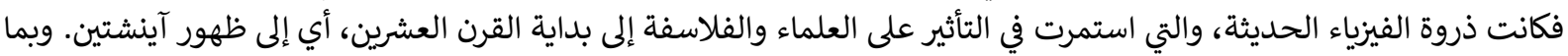

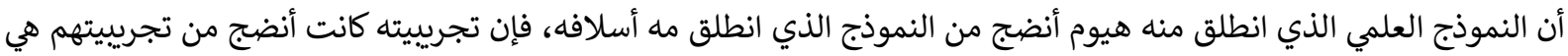

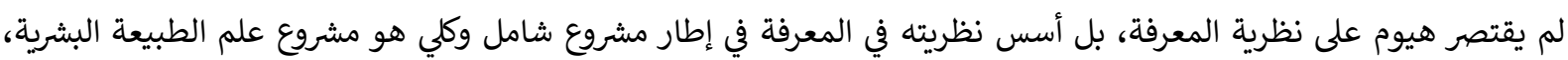

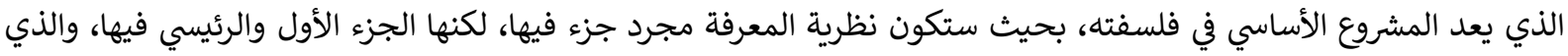

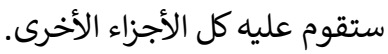

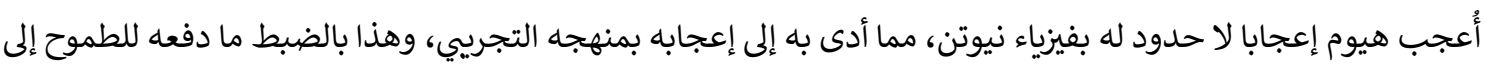

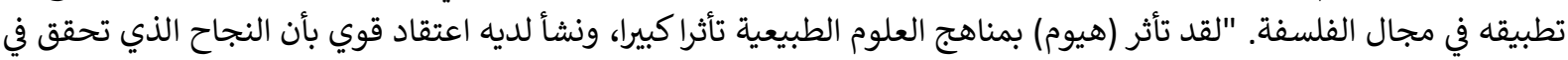

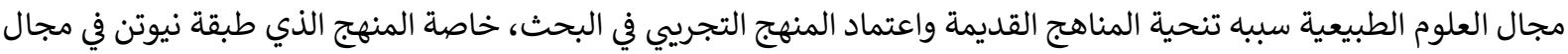

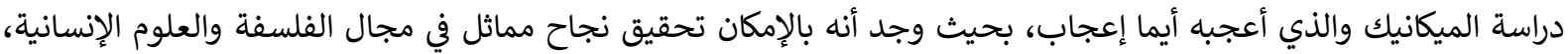

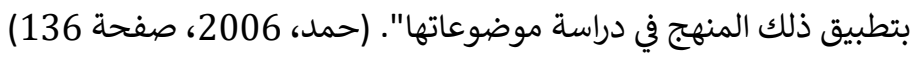

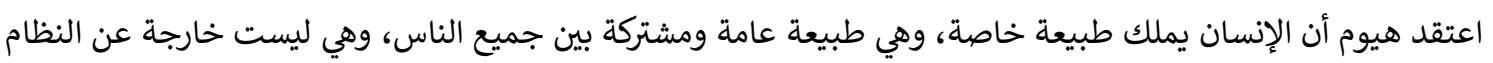

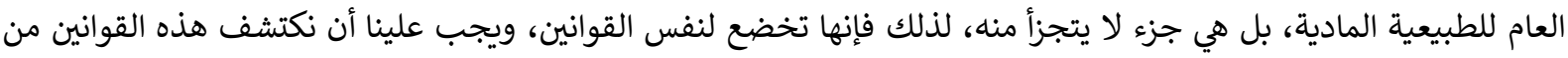

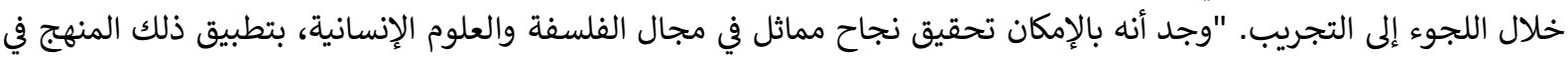

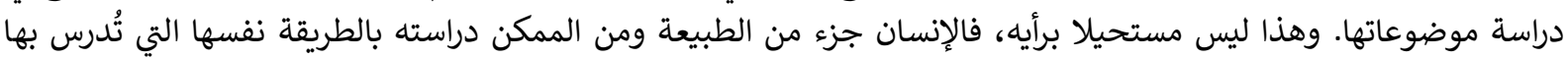

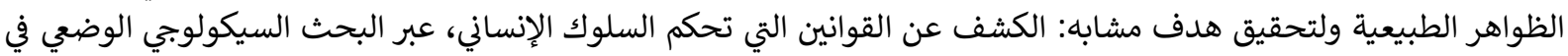

حقل الذهن البشري". (حمد، 2006، صفحة هدفية 136)

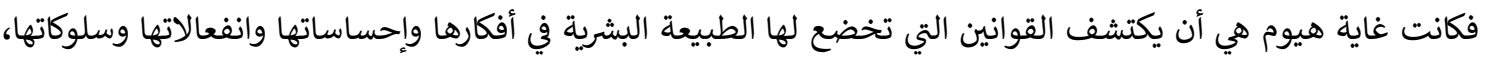

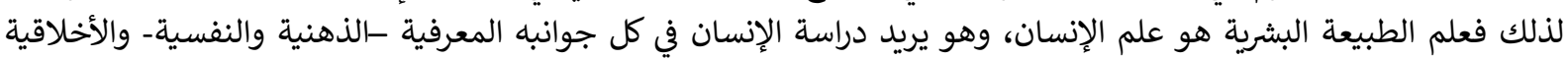

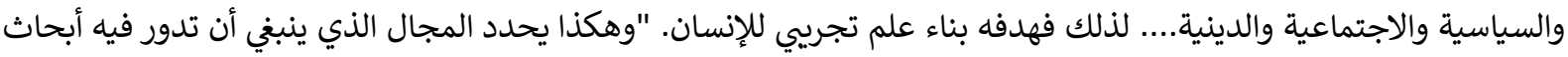

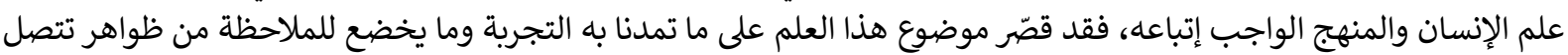

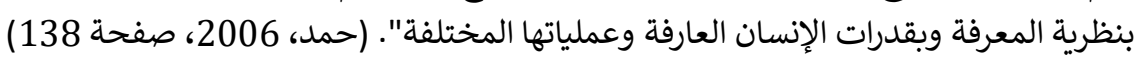

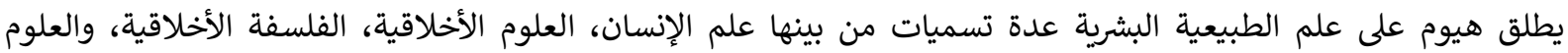

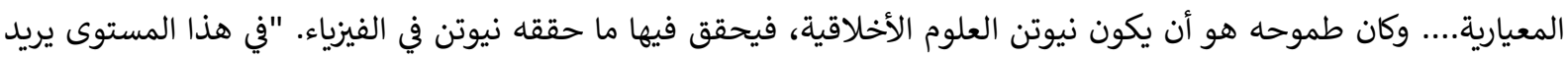


هيوم في الحقيقة أن يكون في مجال الفلسفة، أو فيما كان يُعرف بالفلسفة، أن يكون نيوتن العلوم الجديدة، أي العلوم الأخلاقية، التي يجب أن تحل محل الميتافيزيقا التقليدية".(Michaud, 1983, p. 58)

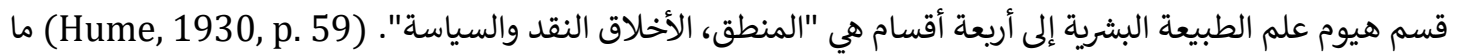

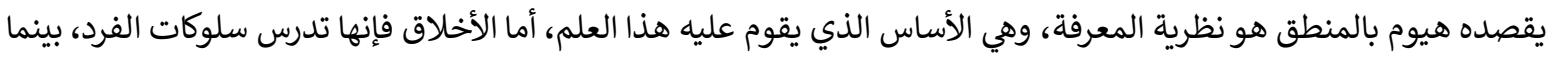

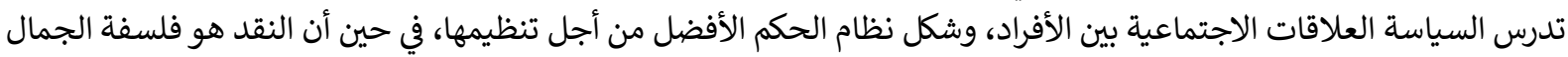

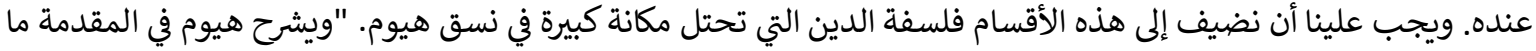

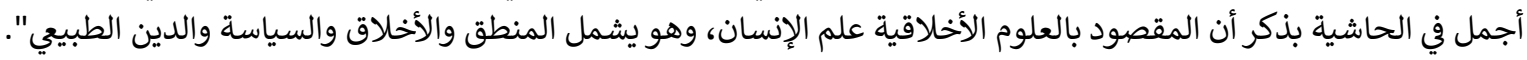

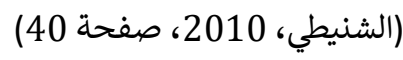

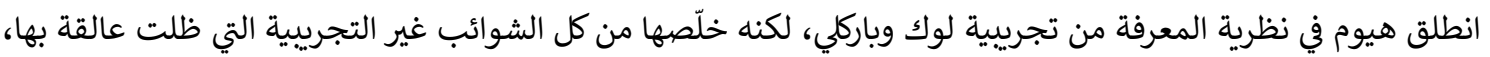

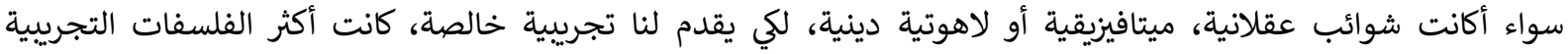

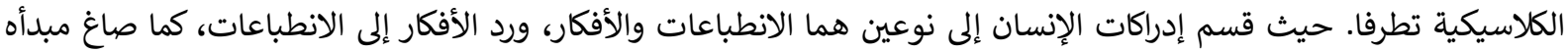

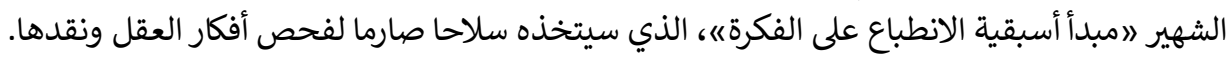

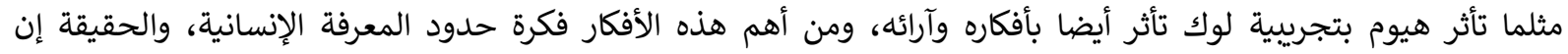

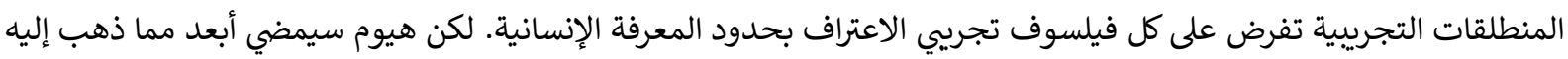

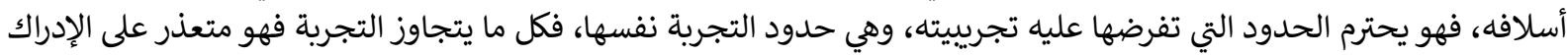

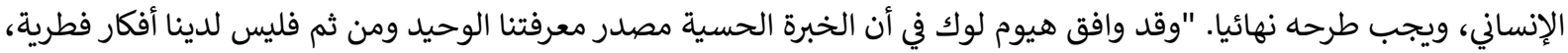

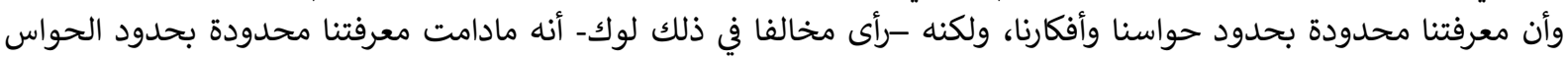

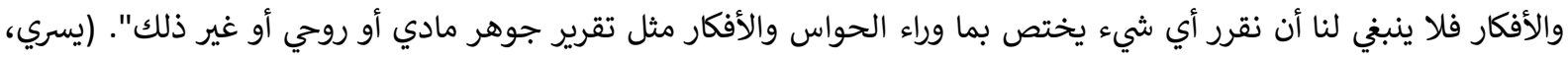

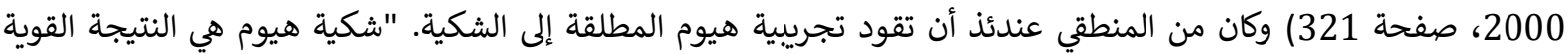

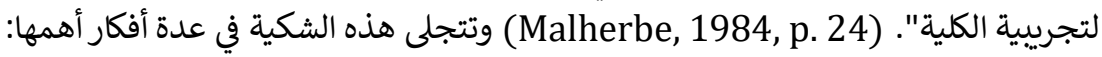

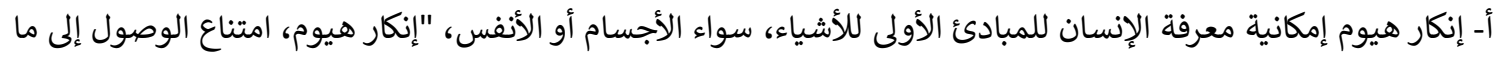

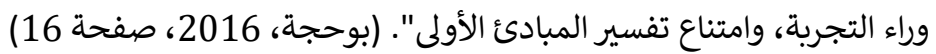

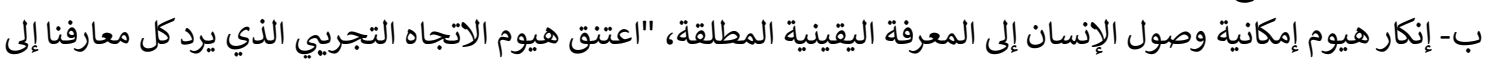

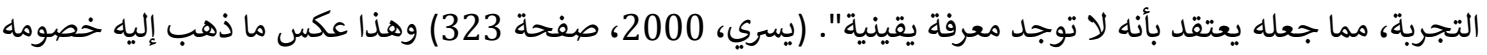
العقلانيون. ج- إنكار هيوم للجواهر الروحية والمادية معا، "أما هيوم الفيلسوف التجريي الثالث، فقد التزاء التزم بهذا المبدأ التزاما تاما،

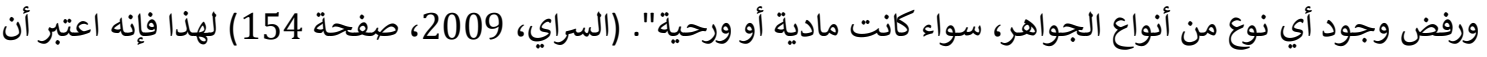

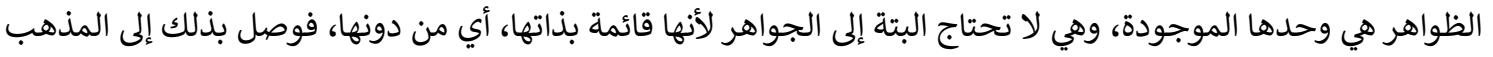

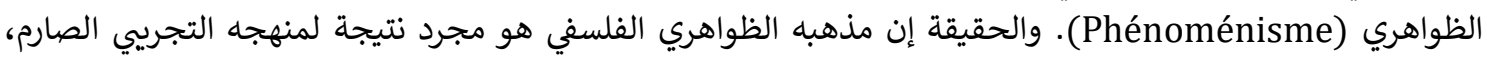

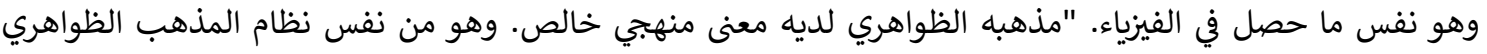

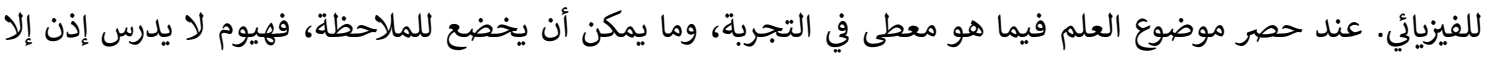

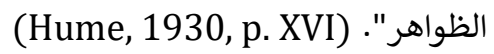

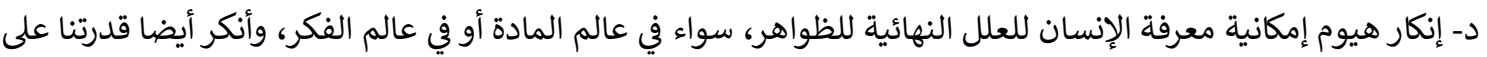

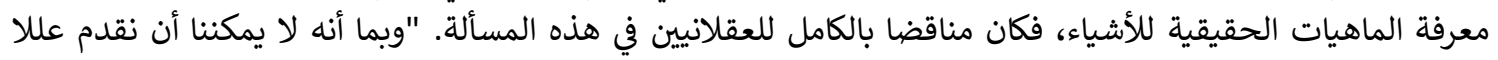

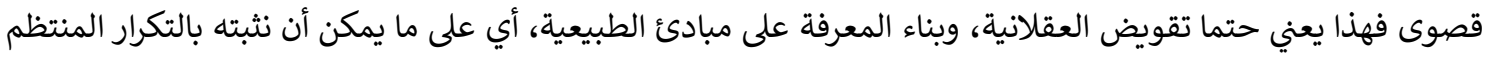

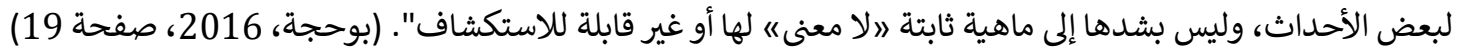

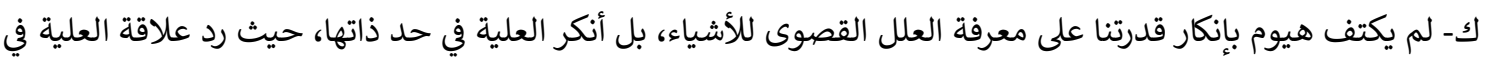

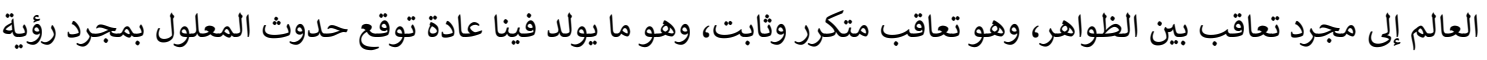
علته.

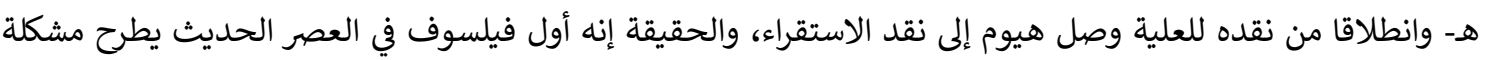

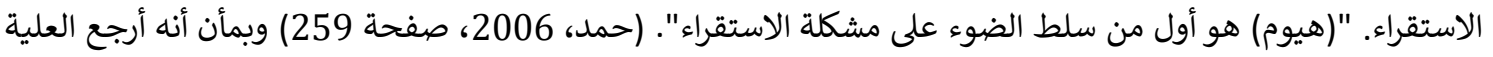

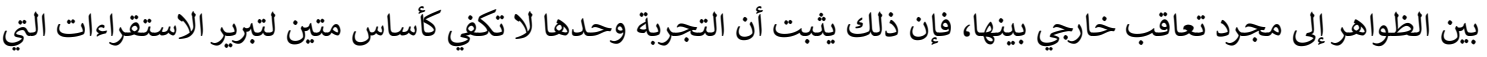

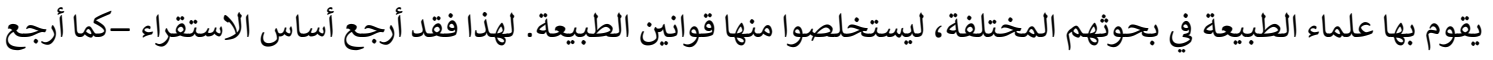

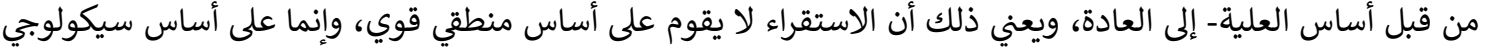

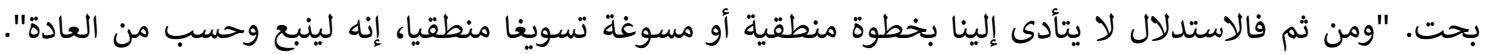




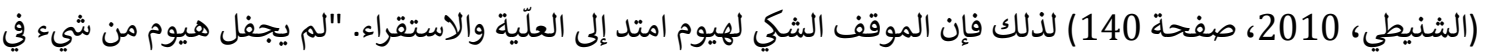

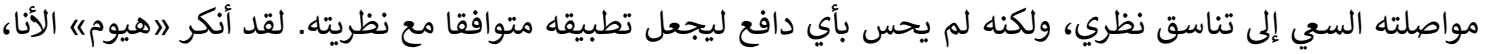

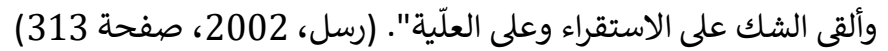

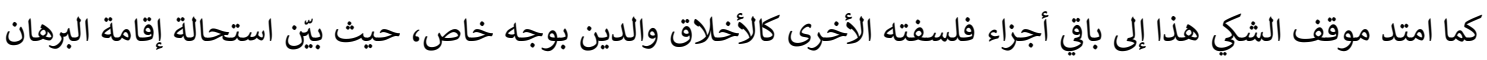

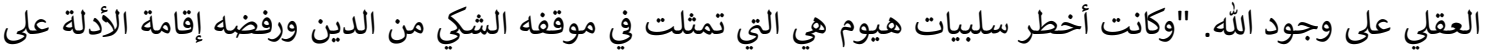

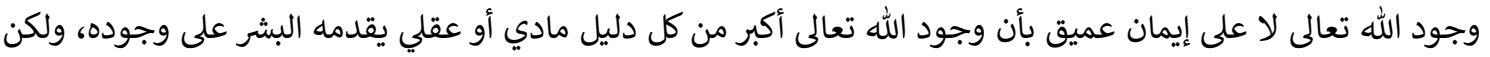

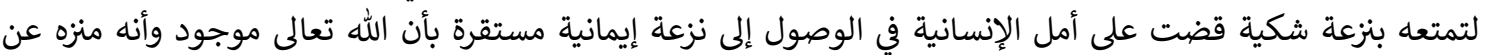

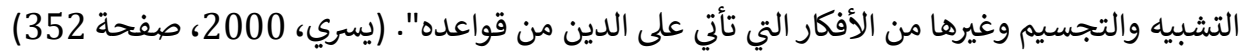

4. تقييم تطبيق الفيزياء في الفلسفة:

بعد أن عرضنا باختصار بعض النماذج من الفلاسفة المتأثرين بالفيزياء في العصر الحديث، نأنياء أتئي الآن إلى تقييم مشروعهمه.

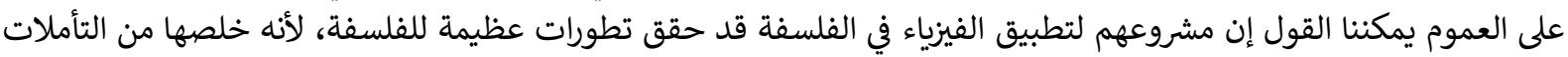

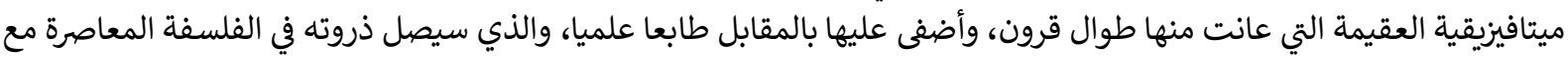
الإبستيمولوجيين الكبار، وسنشرح ذلك أكثر بعد قليل.

أما عن مخاطر تطبيق الفيزياء في الفلسفة فهي كثيرة جدا، وسنذكر بعضا منها. وهي أن النزعة الآلية التي تم نقلها من الفيزياء

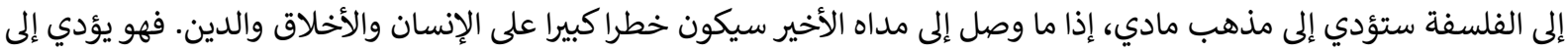

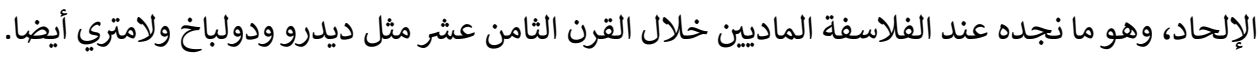

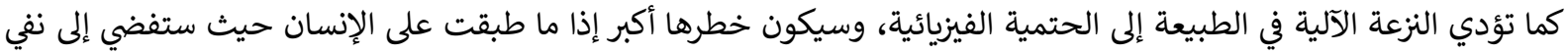

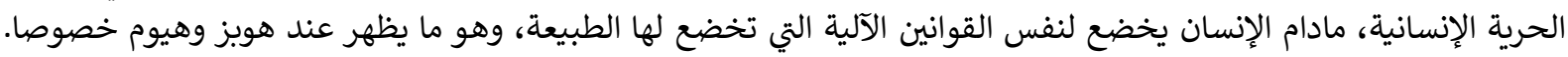

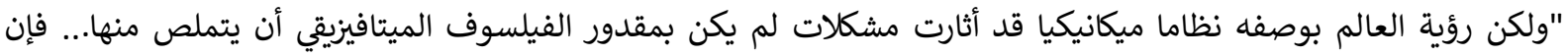

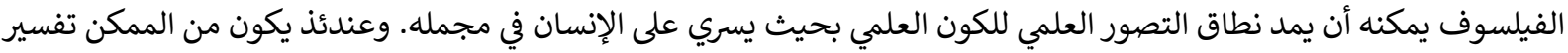

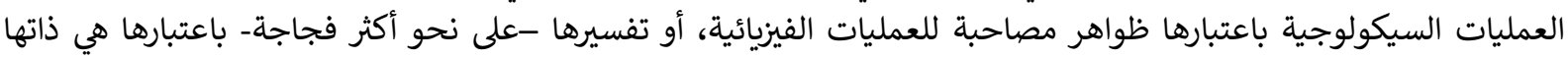

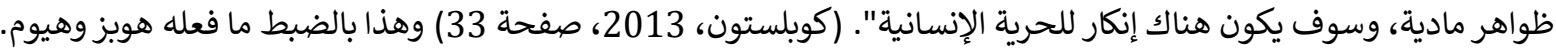

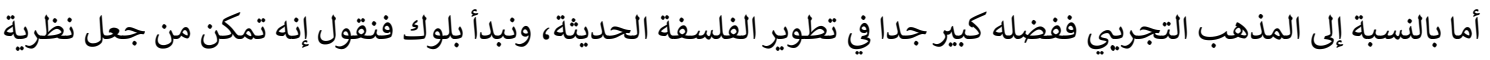

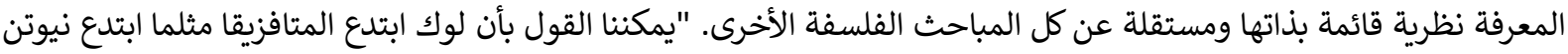

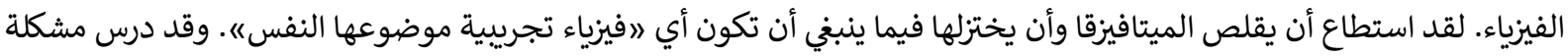

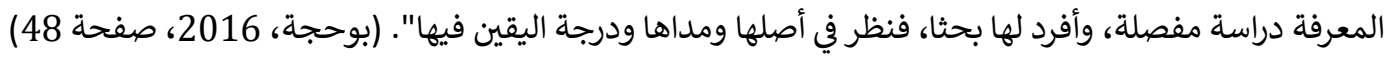

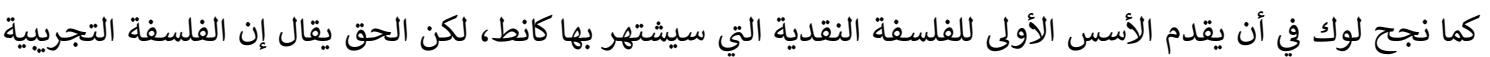

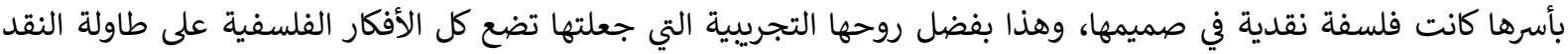

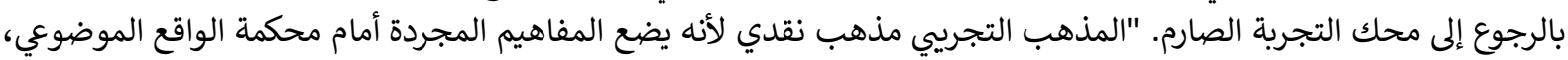

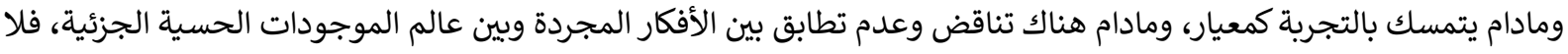

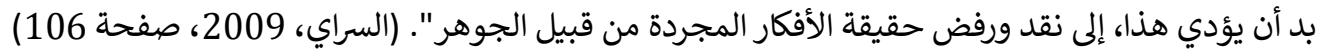

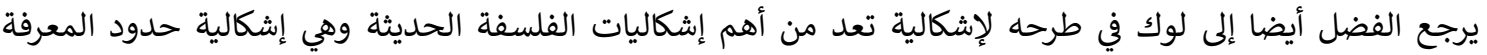

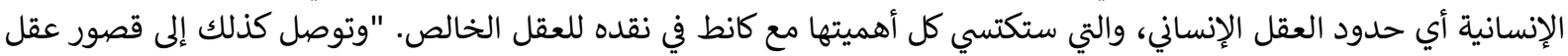

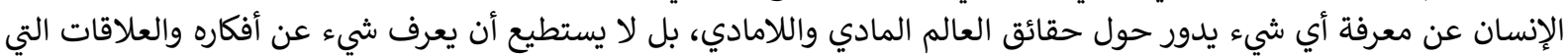

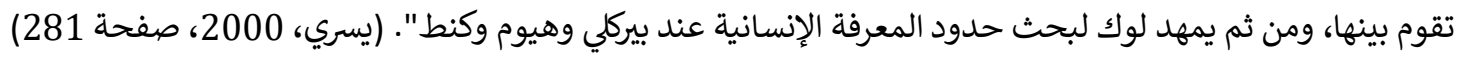

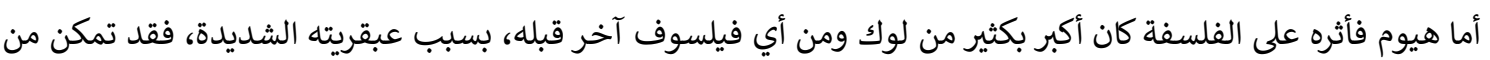

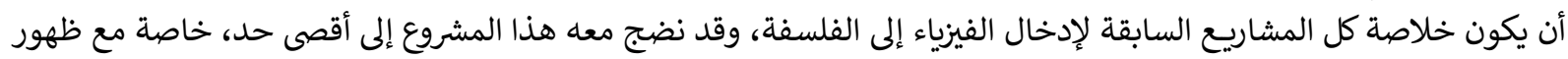

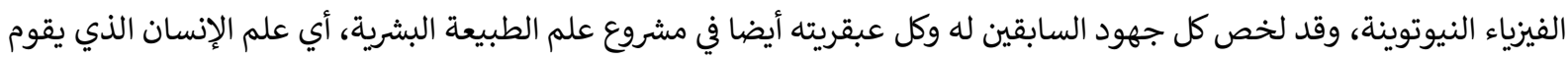
على المنهج التجريي، ويكون بديلا عن الميتافيزيقا التقليدية.

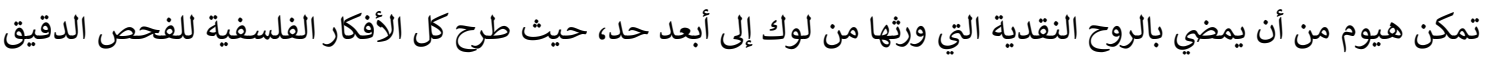

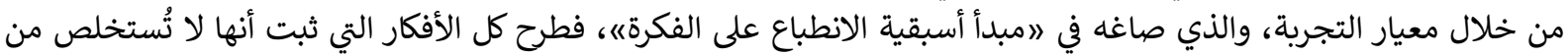

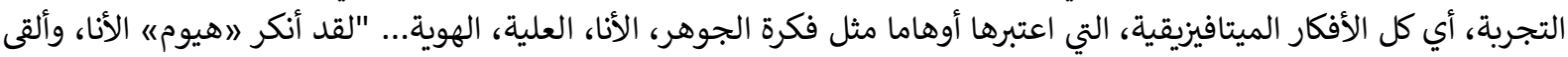

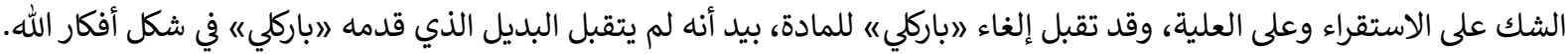


والحق أنه ذهب مذهب لوك في أنه ليس ثمة فكرة بدون انطباع سابق عليها، وليس ثمة شك في أنه تخيل أن 》الانطباعه حالة

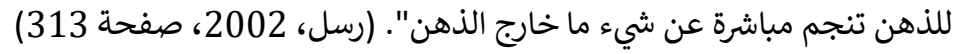

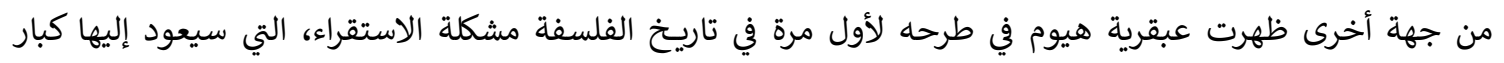

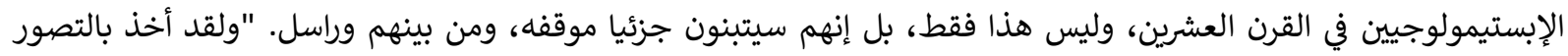

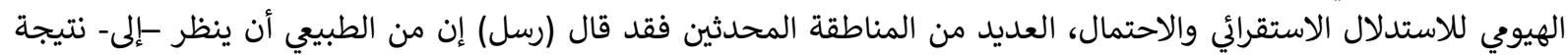

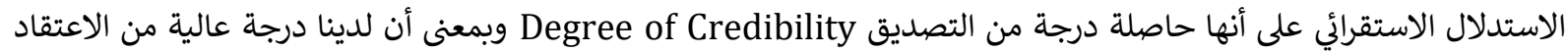

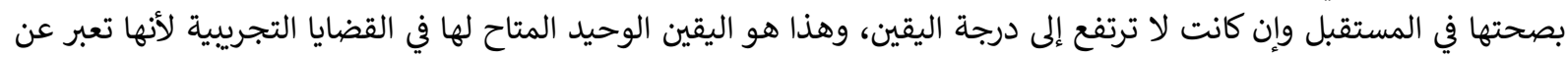

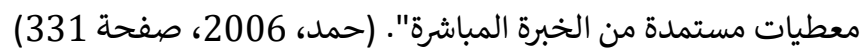

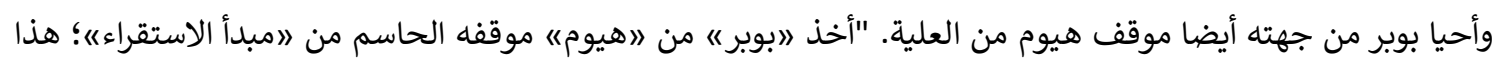

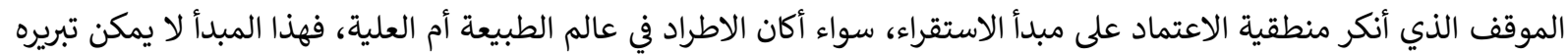

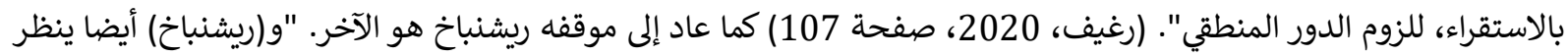

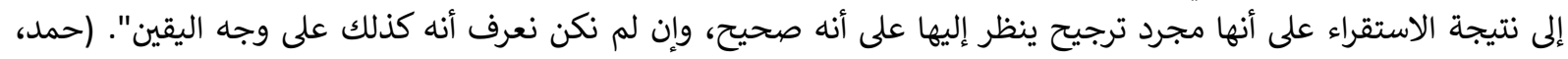

2006، صفحة 332)

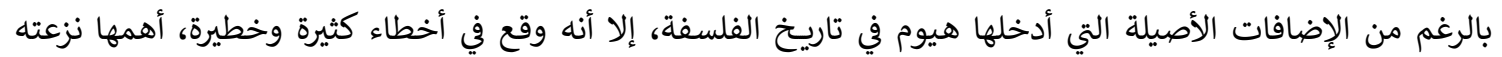

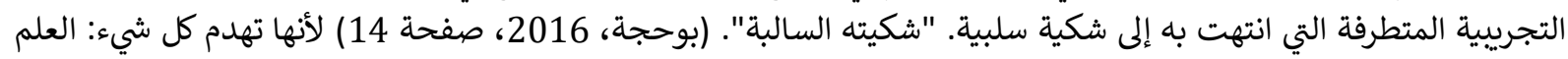

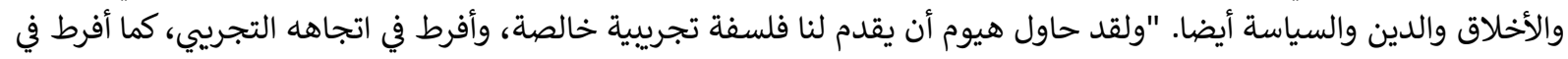

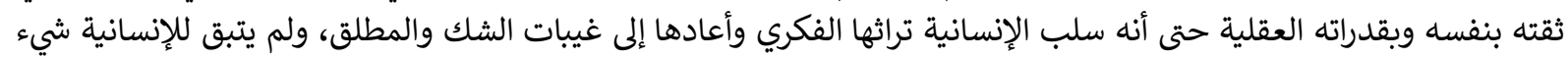

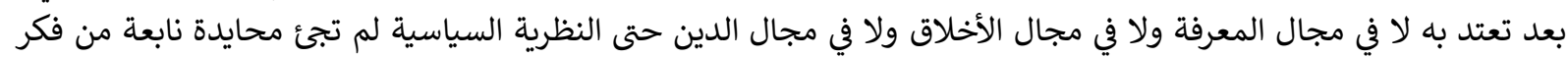

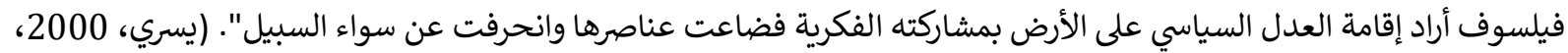

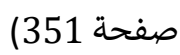

هدم هيوم العلم، لأنه أنكر العلية ولاستقراء وهما أساس العلم الطبيعي الذي يستحيل عليه القيام من دونهما. "كما أخطأ

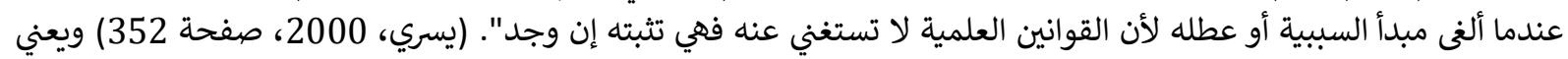

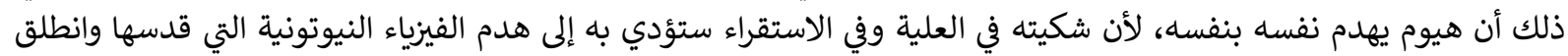
منها في فلسفته.

وانتهى هيوم أيضا من خلال شكيته إلى هدم الأخلاق، لأنه جعلها نسبية بالكامل. "وكاد أن يصل بالأخلاق إلى مبادئ الشك

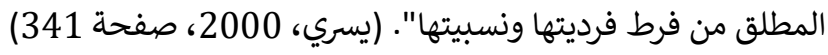

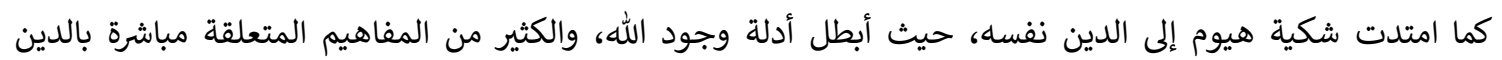

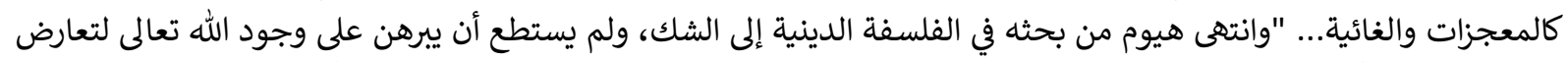

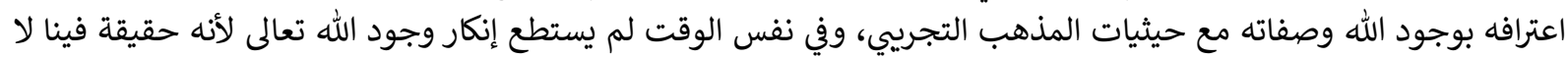

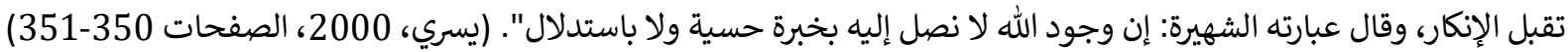

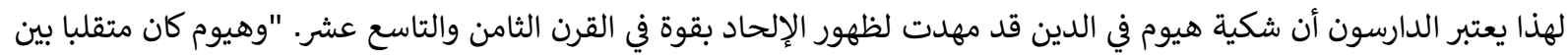

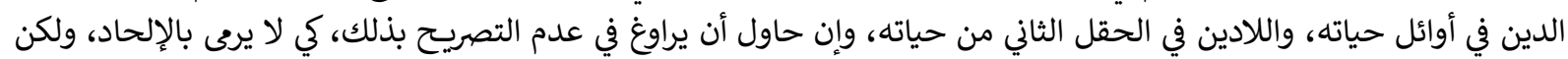

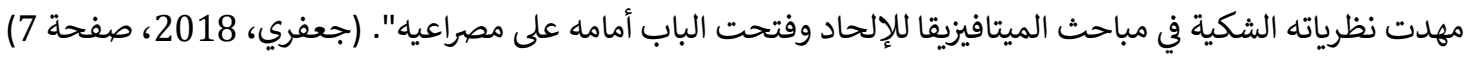

الخاتمة:

يتبين لنا من كل ما سبق أن الفيزياء مارست تأثيرا قويا ومميزا على الفلسفة خلال العصر الحديث -من باتئ بدايته إلى نهايته-

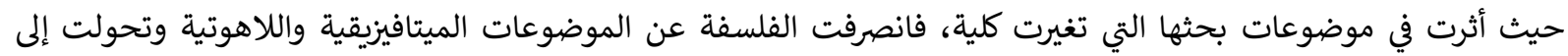

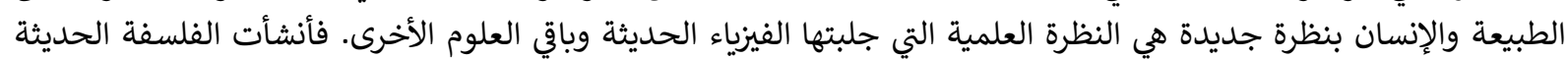

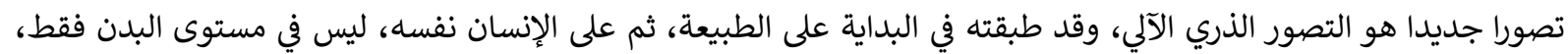

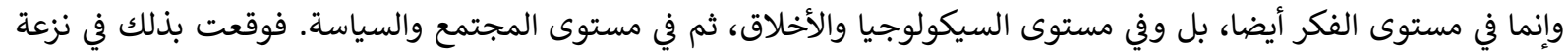

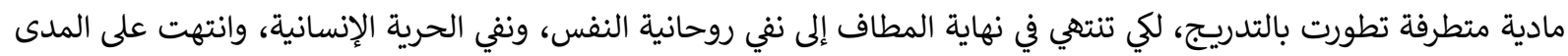
البعيد إلى إنكار وجود الله.

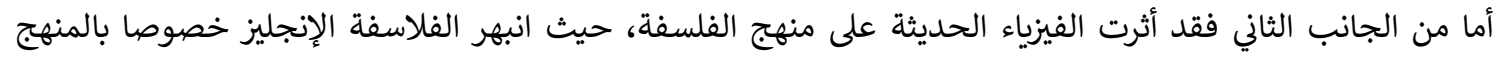

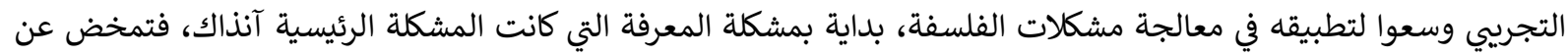


ذلك ولادة المذهب التجريي الحديث على يد لوك، وتطوره مع باركلي، ووصوله ذروته مع هيوم. وامتد تطبيق المنهج بالتجريب

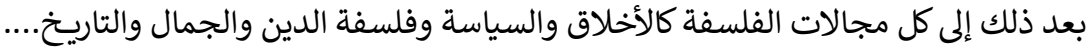

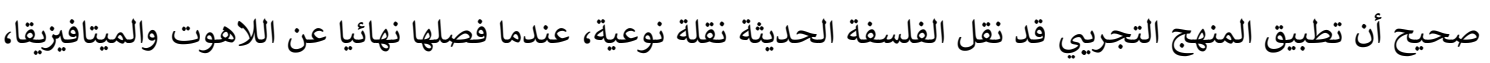

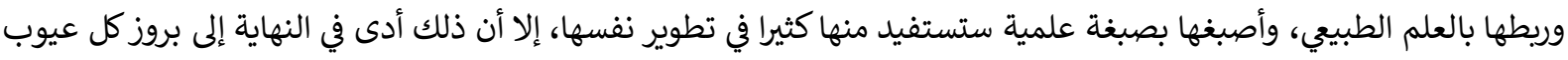

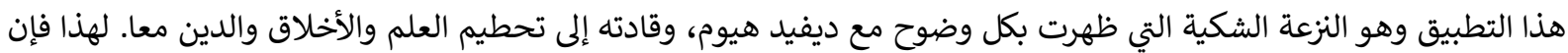

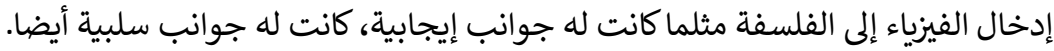

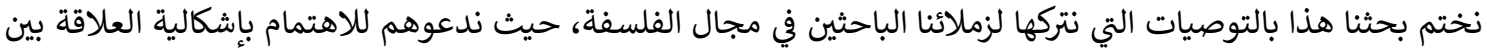

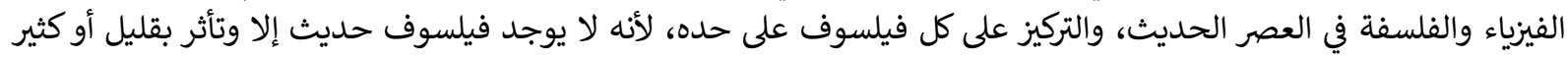

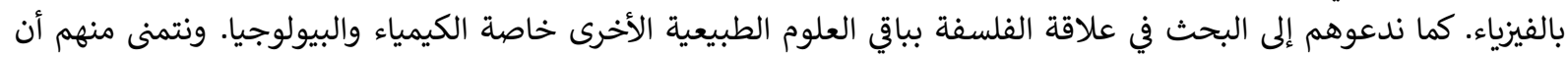

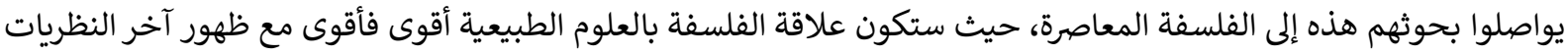

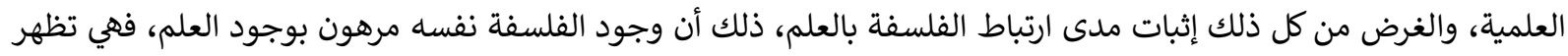
بظهوره وتتطور بتطوره. 
John Locke (2004), Essai Sur l'Entendement Humain, Traduit par Pierre Coste, Paris, Edition Champion.

2-David Hume (1930), CEuvres Philosophiques choisies. Traité de la Nature Humaine, Traduit de l'anglais par Maxime David Paris, Librairie Félix Alcan, Nouvelle édition.

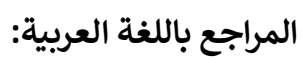

أيوب أبودية (2001)، علماء النهضة الأوروبية، لبنان، دار الفارابي، الطبعة الأولى.

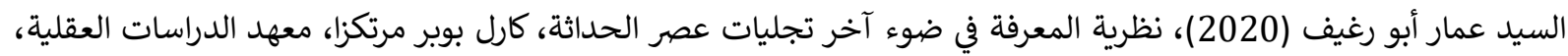

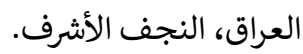

حسون السراي، (2009). مفهوم الجوهر في الفلسفة الحديثة، بيروت، لبنان، دار الهادي للطباعة والنشر والتوزيع، ط1.

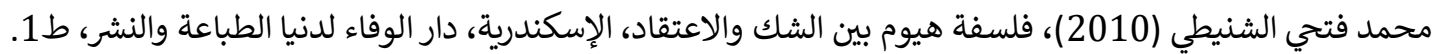

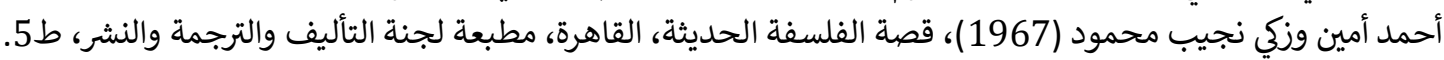

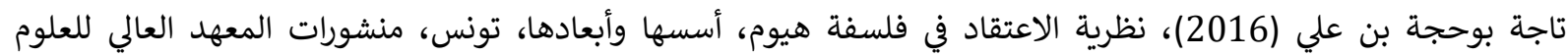
الإنسانية، المنار.

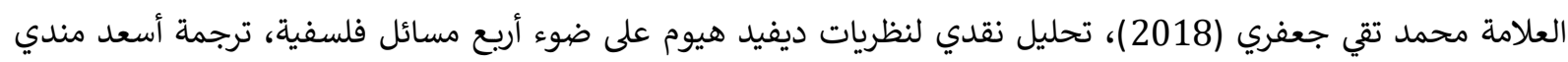

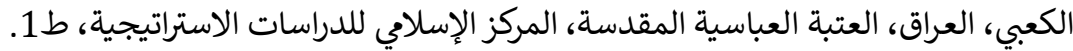

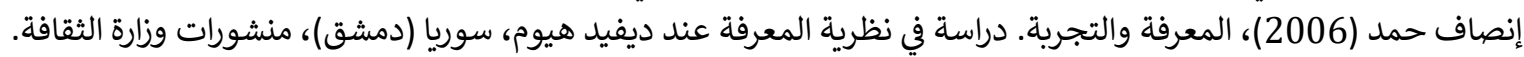

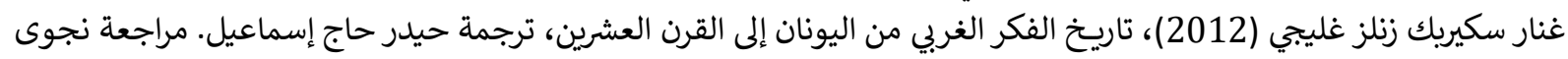

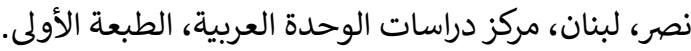

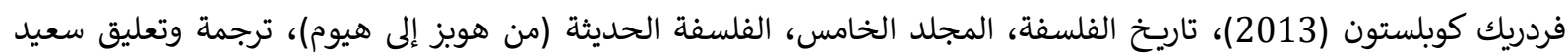

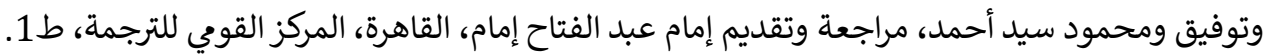

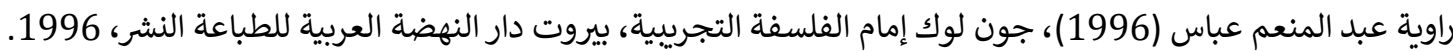

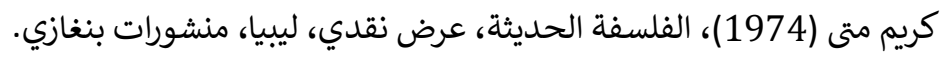

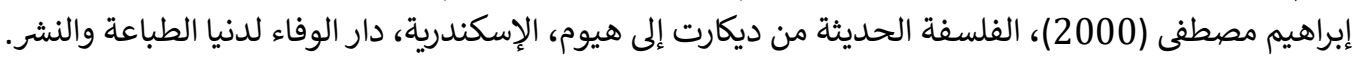

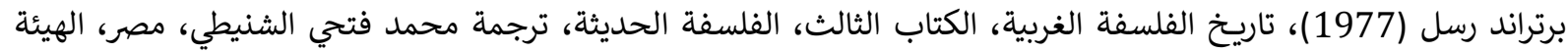

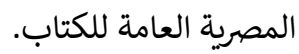

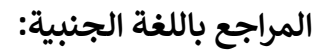

Harald Höffding, (1906), Histoire de la Philosophie Moderne, Traduit par Victor Delbos, Paris, Félix Alcan, éditeur, Tome1.

Michel Malherbe (1984), La Philosophie Empiriste de David Hume, Paris, Librairie Philosophique J. Vrin.

Yves Michaud (1983), Hume et la fin de la philosophie, Paris, Presses Universitaires de France, Roger Verneaux (1958), Histoire de la Philosophie Moderne, Paris, Beauchesne et ses fils. 
THE HISTORY AND CIVILIZATION OF THE CITY OF ALGIERS DURING THE PERIOD OF HUSSEIN DEY

Hayat MEKKI 


\title{
THE HISTORY AND CIVILIZATION OF THE CITY OF ALGIERS DURING THE PERIOD OF HUSSEIN DEY
}

\section{Hayat MEKKI ${ }^{1}$}

\begin{abstract}
:
The midwives era 1671/1830 AD constitutes the most important stages of the Ottoman era in the province of Algeria, due to the length of this period in terms of temporal extension - a century and fiftynine years - and to the events that characterized it. Hamdan Khoja described him, saying, "This virtuous man belongs to a noble family, and he enjoys a wide culture, and he has served the Eyala for more than thirty years, ......, that he is of that ancient Turkish origin, meaning that he is an honorable and generous soul."

He had many works and achievements in various fields. He was interested in projects of public interest. He carried out financial reforms represented in the issuance of a new currency. He built a new house for the railway. He strengthened the city's defenses. He also made other achievements represented in building a house for his residence, and a mosque, as well as the restoration of the Great Mosque. And bring water to the city of Algiers.

From this point of view, we ask a question about this period that was ruled by $\mathrm{m} y$ father Hussein, what are the most important historical and civilizational manifestations that Algeria witnessed during this period?.
\end{abstract}

Key words: Hussein Dey, Civilizational Manifestations, Civllization of The City of Algiers .

${ }^{1}$ Zayan Ashour University Djelfa, ALgeria, cham.hayet@ gmail.com, https://orcid.org/0000-0002-1344-7544 


\section{مكي حياة 2}

الملخص:

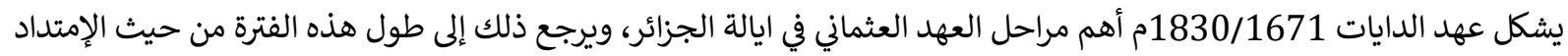

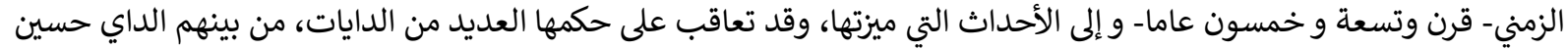

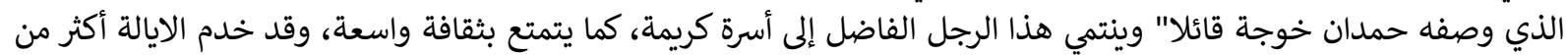

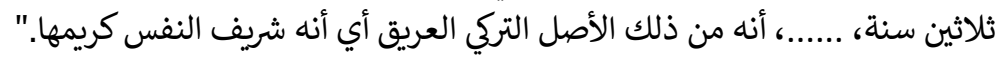

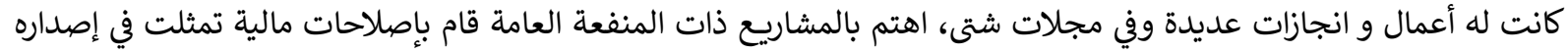

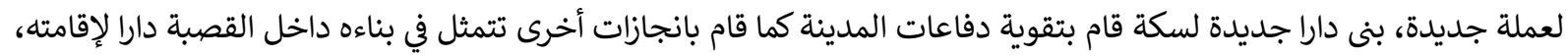

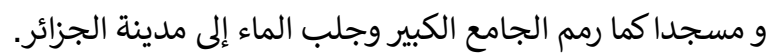

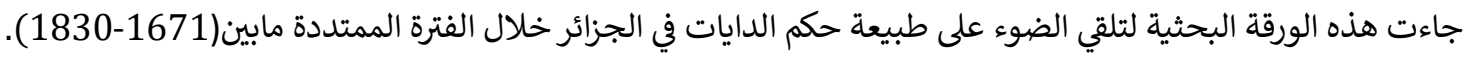

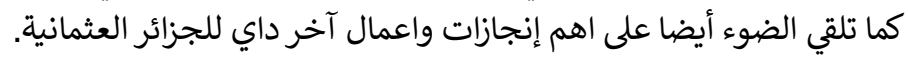

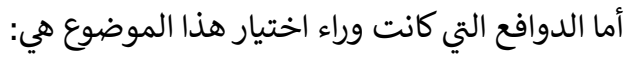

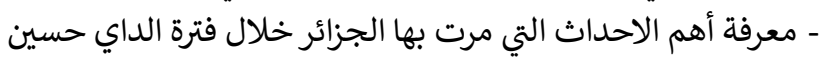

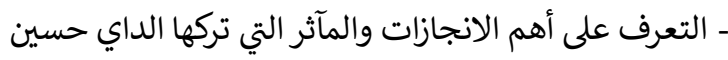

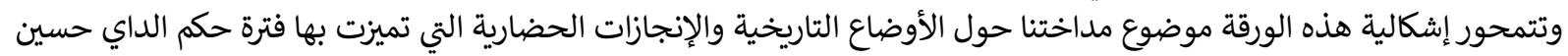
بالجزائر. من هذا المنطلق نطرح تساؤل حول هذه الفترة التي حكمها الداي حسين ماهي أهم المظاهر التاريخية، والحضارية التي شهدتها

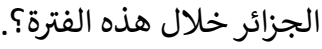
الكلمات المفتاحية: حضارة مدينة الجزائر، الداي حسين، والإنجازات الحضارية.

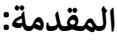

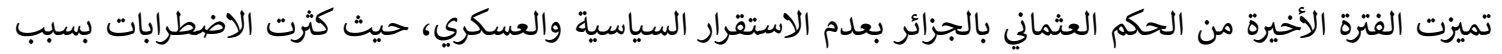

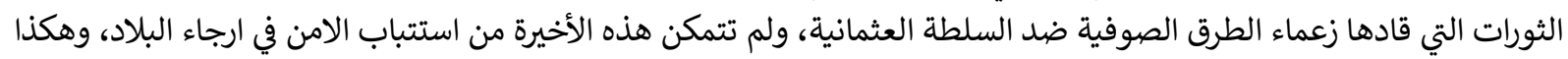

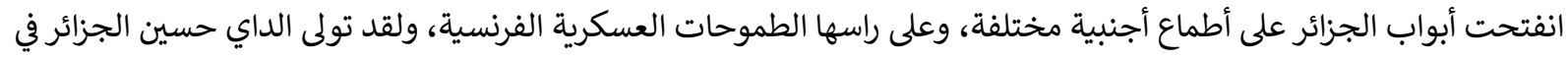

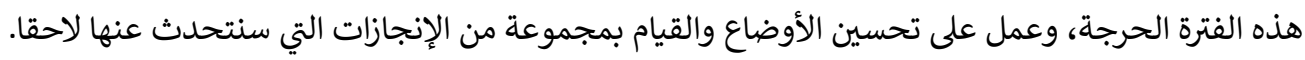

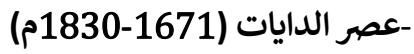

لقد استفاد حكام الجزائر من تجارب الحكم السابق، بحيث حاولوا ترقية السلطان العثماني وتقوية مركز الحاكم (الداي)،

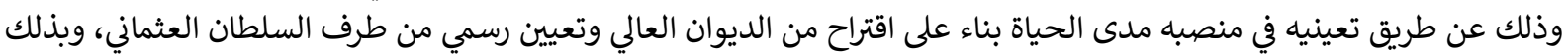

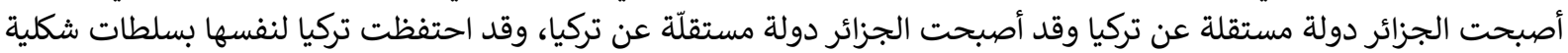

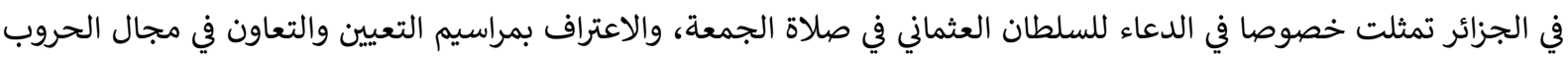

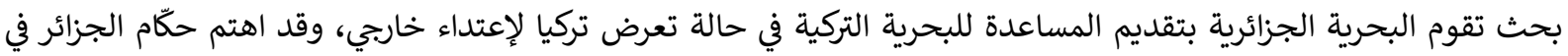

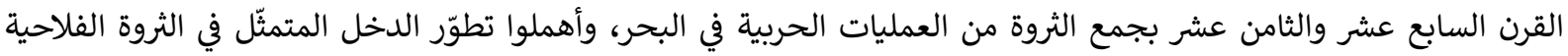

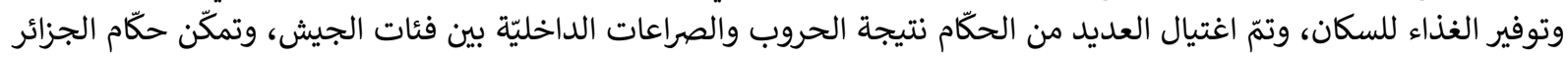

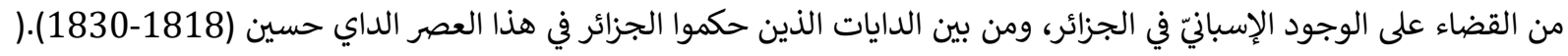

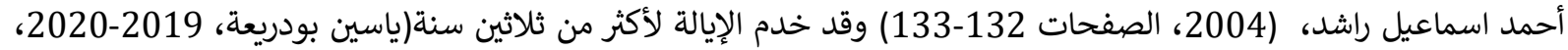

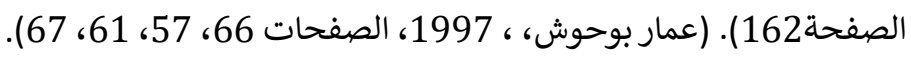

ayla.hayet@gmail.com جامعة زيان عاشور ، الجزائر، 


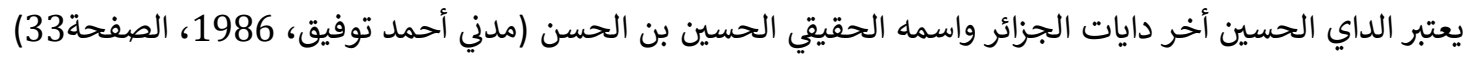

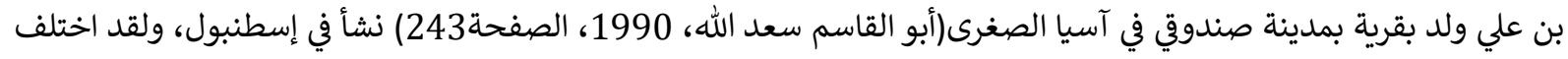

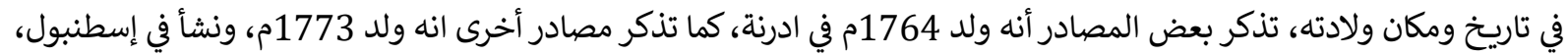

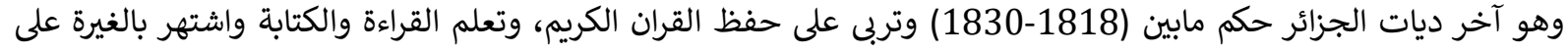

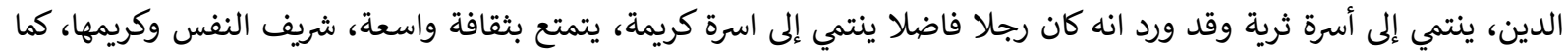

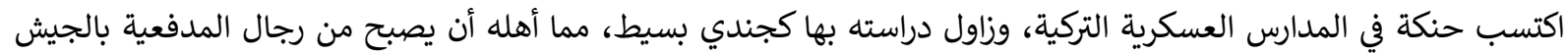

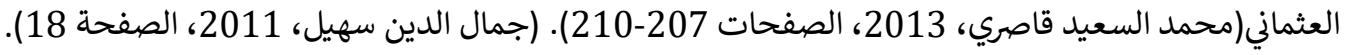

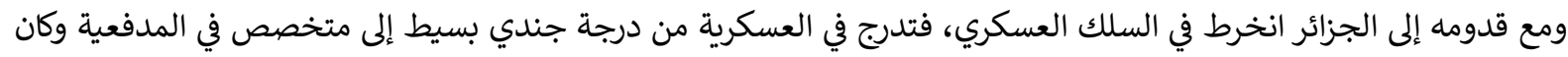

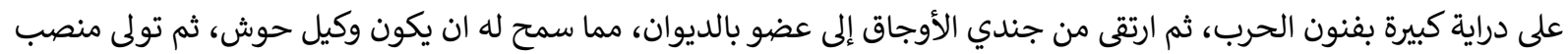

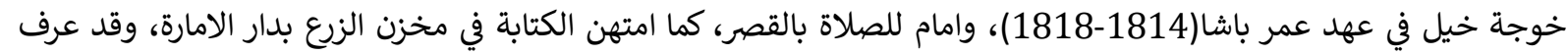

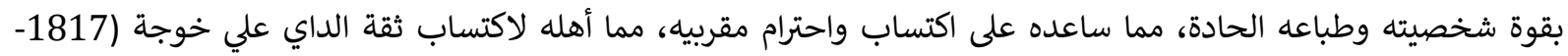

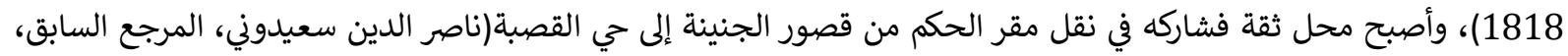

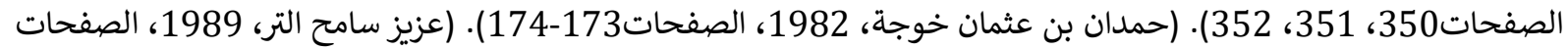

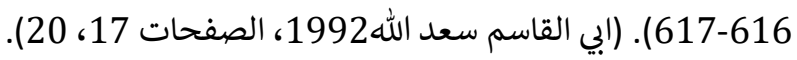

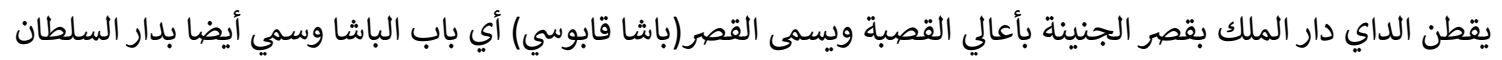

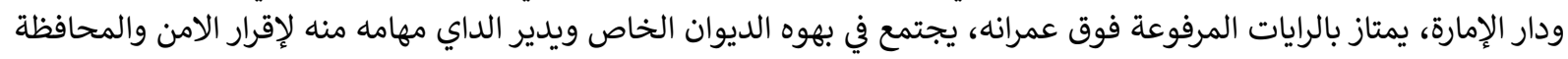

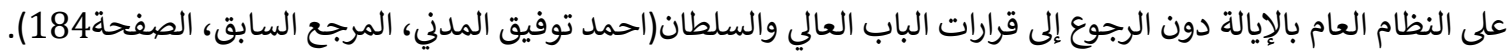

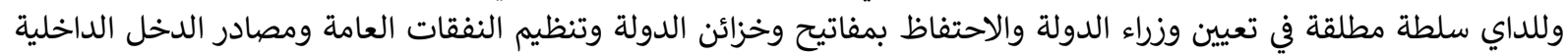

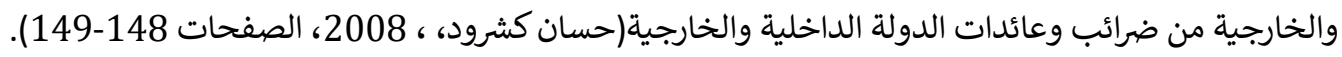

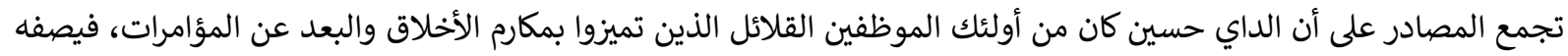

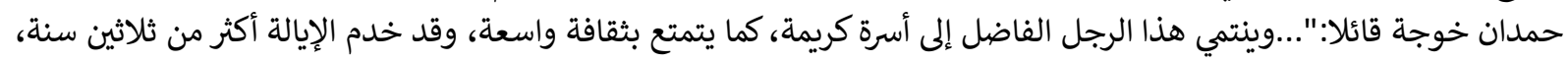

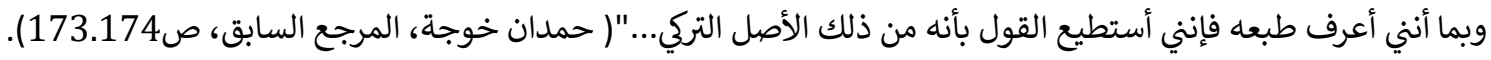

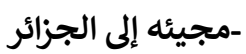

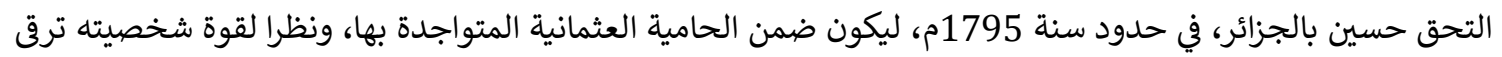

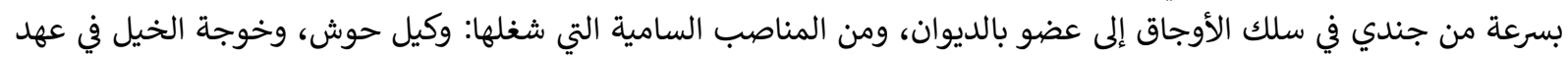

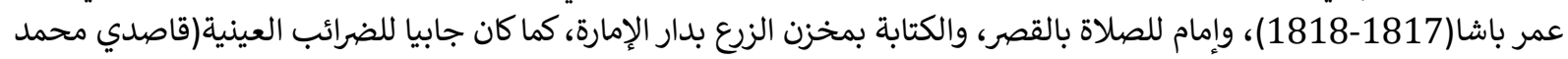

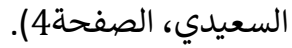

$$
\begin{aligned}
& \text { • • مآثراه } \\
& \text { تنظيم الإدارة والإعتناء بالبحرية(ناصر الدين 1995، الصفحةهة إنداه 158)، وضبط أمور الجيش }
\end{aligned}
$$

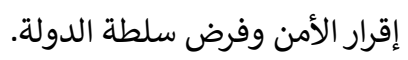

$$
\begin{aligned}
& \text { فرض هيبة الجزائر في تعامله مع الدول الأوربية. }
\end{aligned}
$$

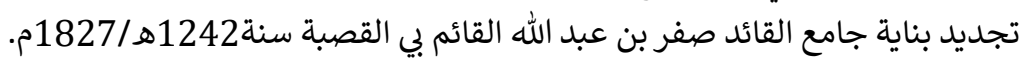

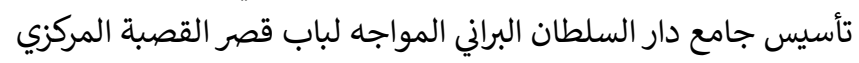

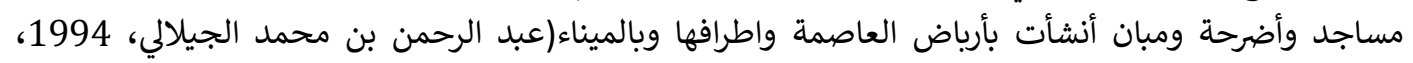

الصفحات333-333) (333).

- الأوضاع التاريخية في عهد الداي حسين

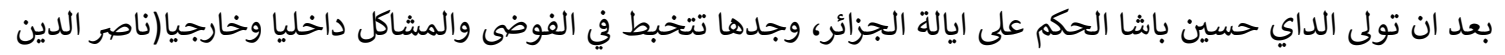

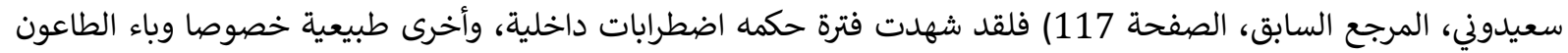

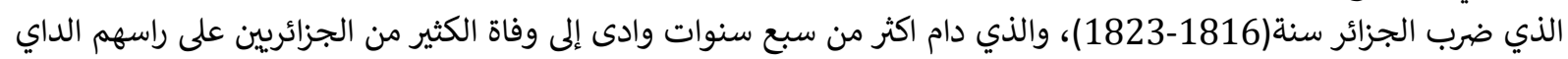

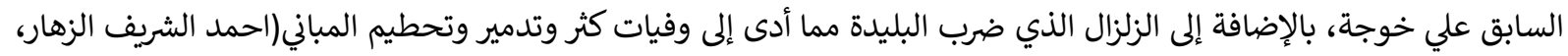
المرجع السابق، الصفحات خوجة، بالاضافة 144، 145). 
- داخليا:

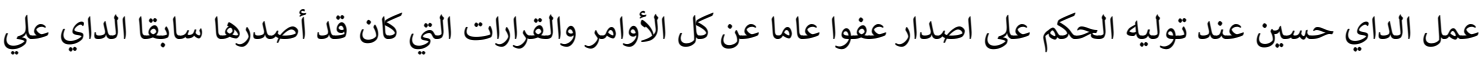

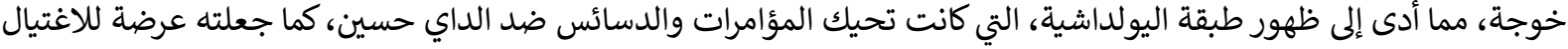

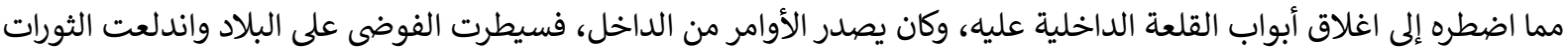

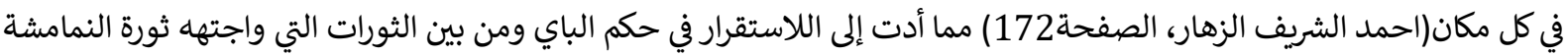

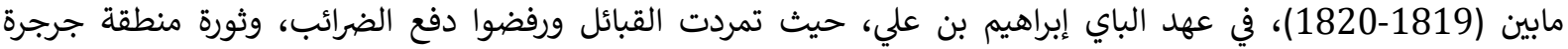

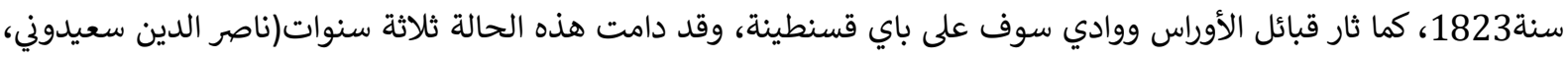

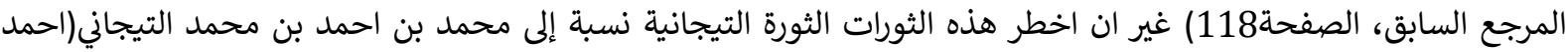

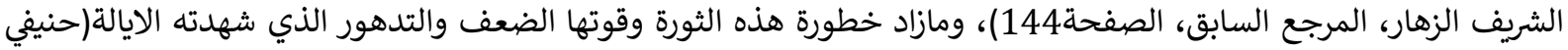

هلالي، 2008، الصفحة 53).

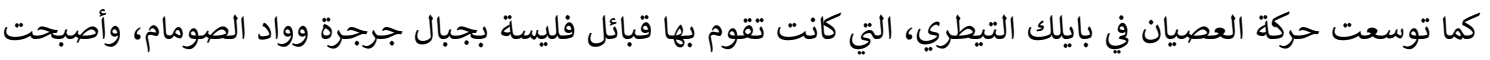

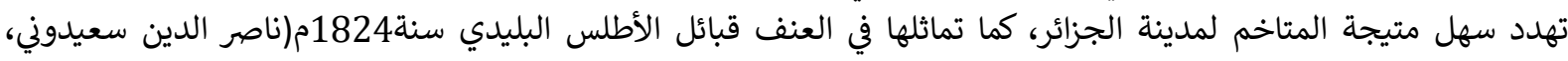

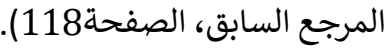

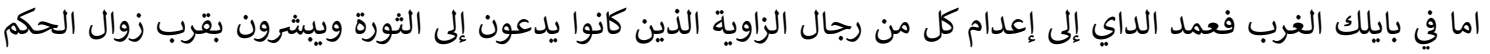

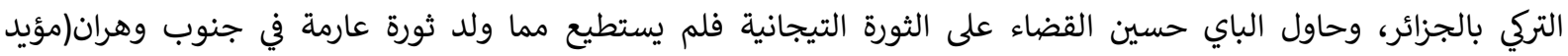

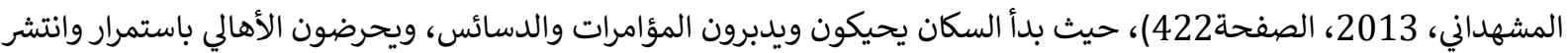
المرابطون في كافة الأطراف وأعلنوا صراحة العداء للأتراك، فبدأت دائرة التمرد تتسع وتزدادادعزيز سامح التر، المرجع السابق،

الصفحة621).

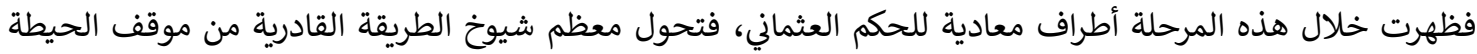

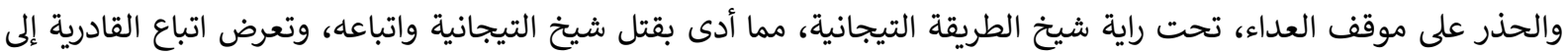

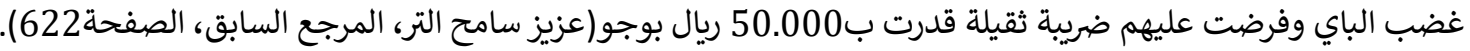

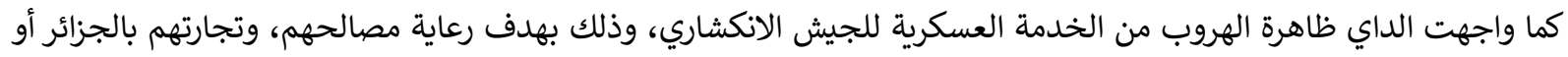

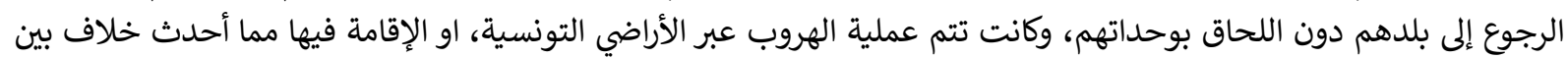
الايالتين.

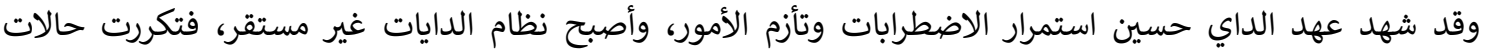

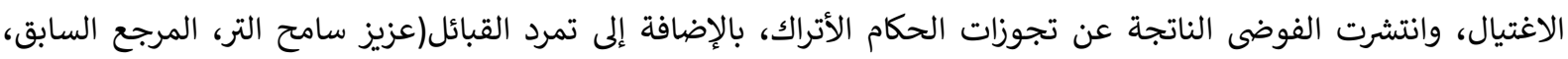

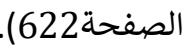

خارجيا

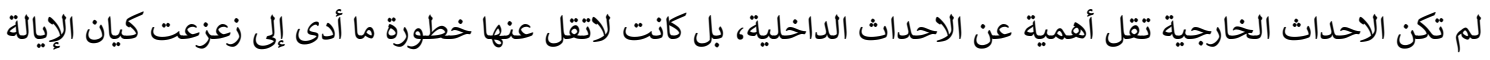

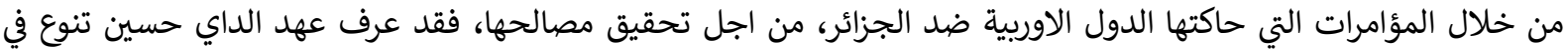

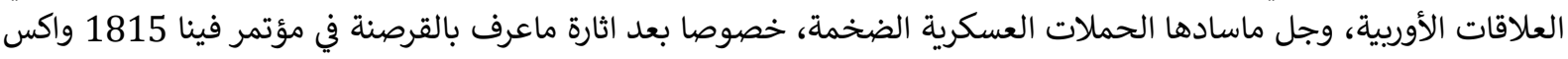

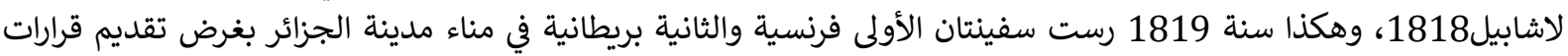

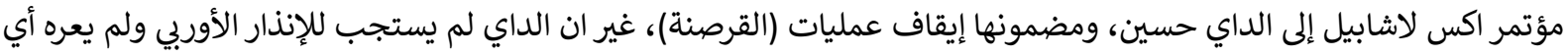

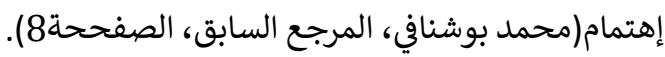

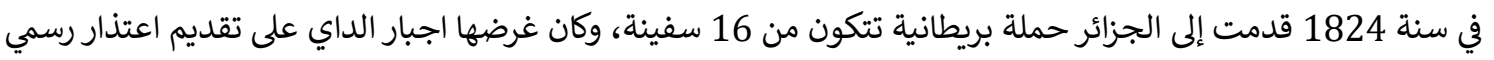

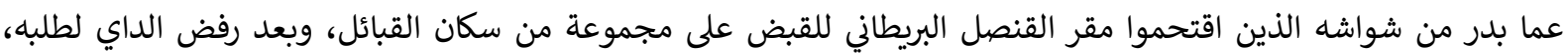

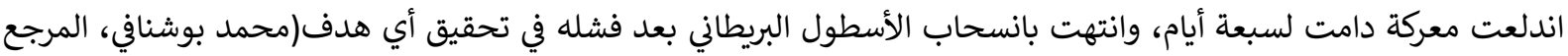

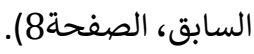

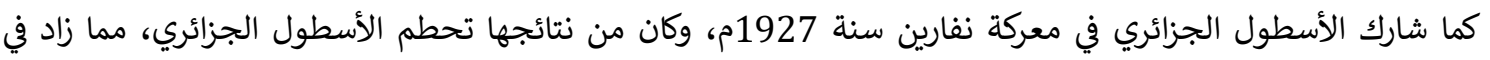

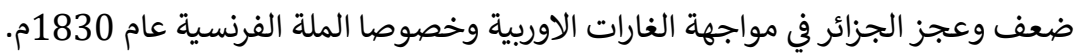


- أعماله وإنجازاته

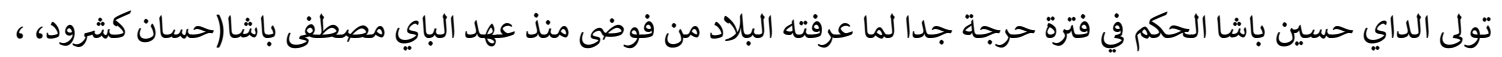

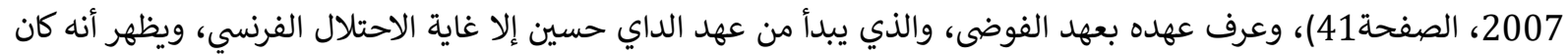

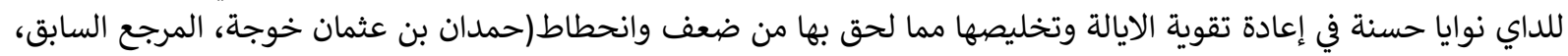

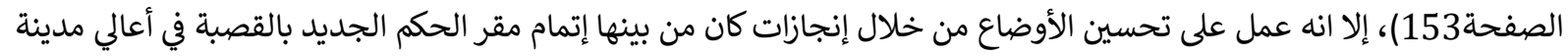

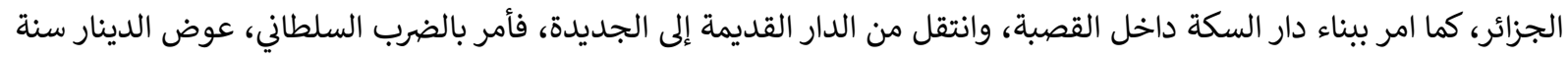

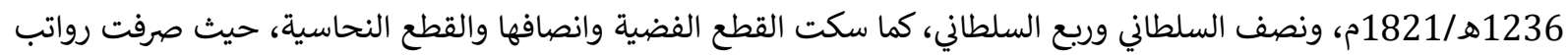

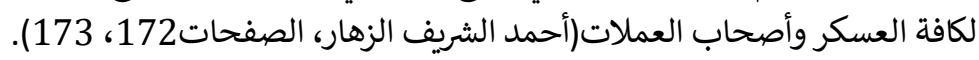

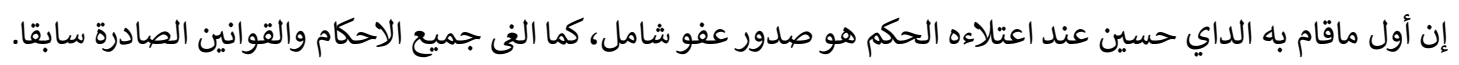

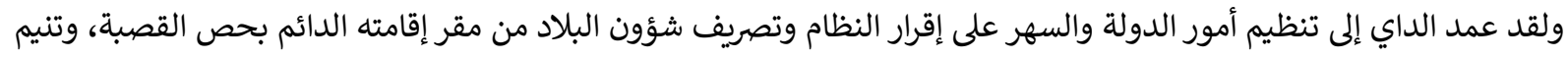

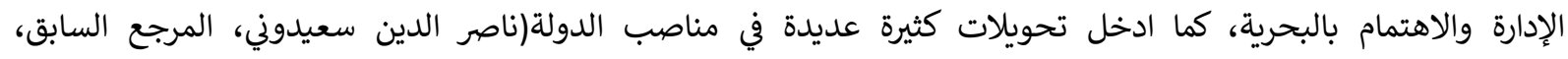

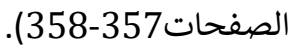

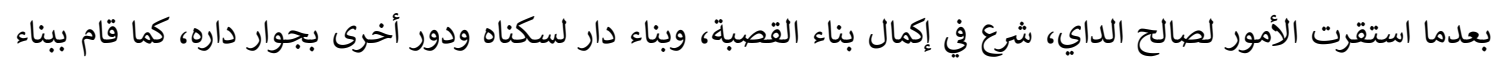

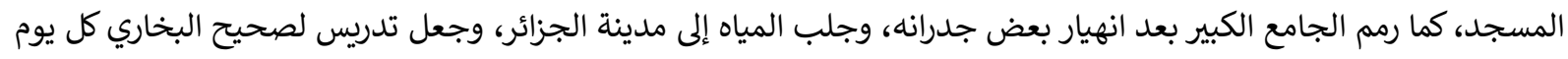

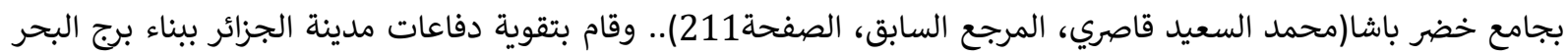

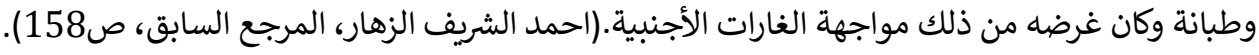

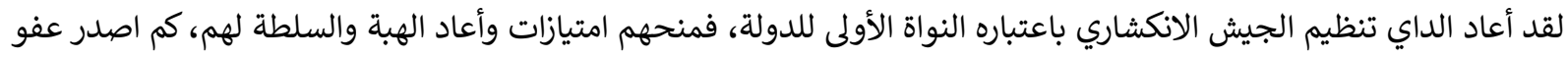

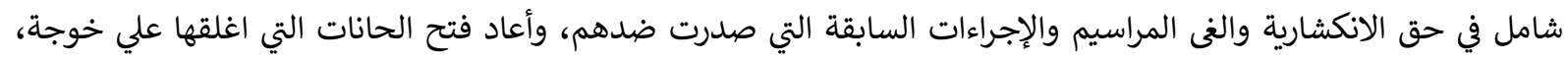

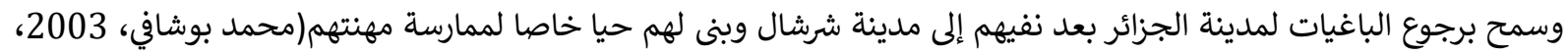

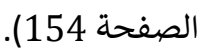

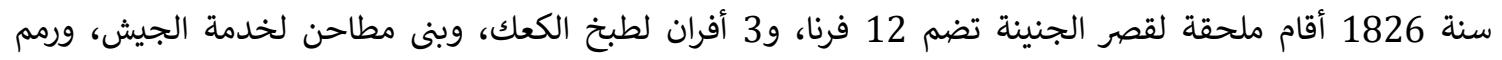

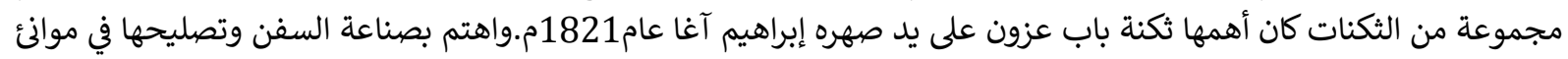

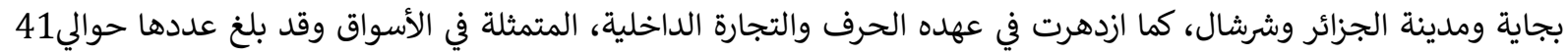

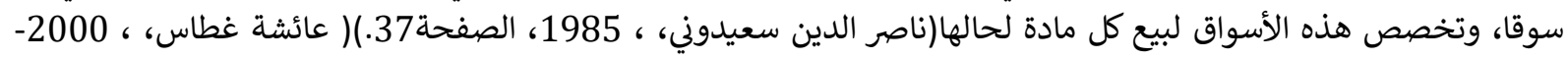

2001، الصفحات260، 261، 261).

\section{ومن بين أهم الإنجازات المعمارية التي تركها الداي حسين نذكر مايلي: \\ - قصر الحمراء}

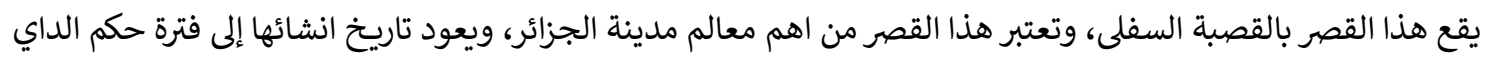

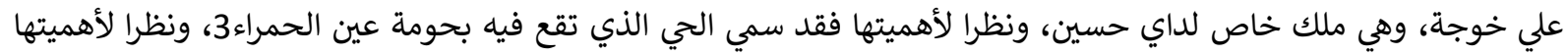

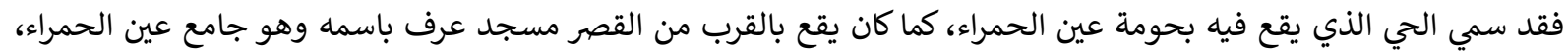

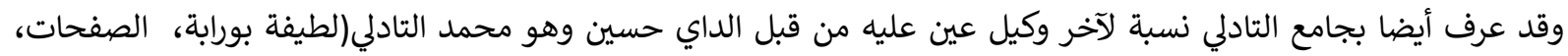

163، 162

وصفها "كلاين" رئيس لجنة الجزائر العتيقة عام1913 أنها"سلبت الباب الزائرين لها بالمريعات الخزفية الهولندية واناقة

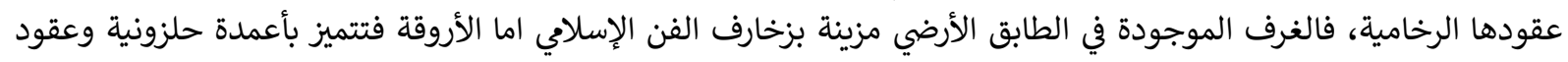

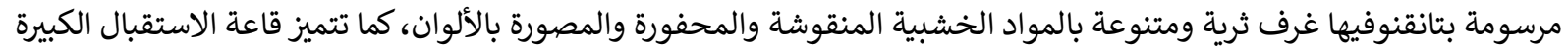

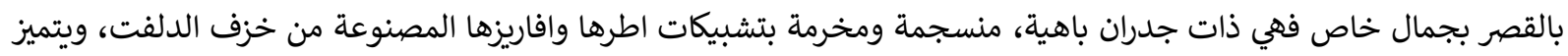

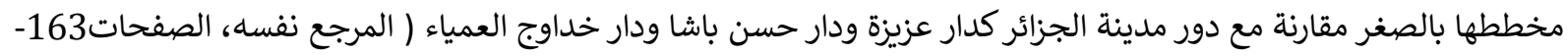

وقد خضعت لسلسلة من التحولات، بسبب تطويرها بشكل خاص كفندق لمديرالتحصينات، ثم لتوسيع المسارات

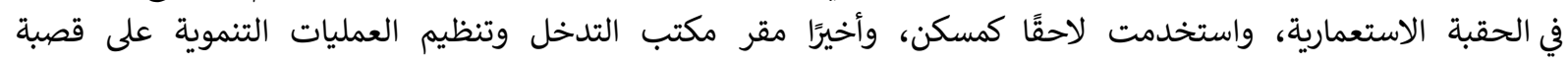

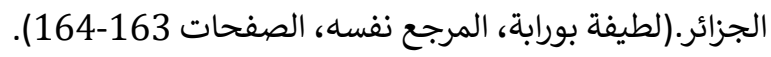


صُنفت دار الحمراء سنة 1887. وخضعت للأعمال الترميمة الخفيفة في عام 1986 وأعمال الترميم بعد زلزال 2003. - قصر الداي

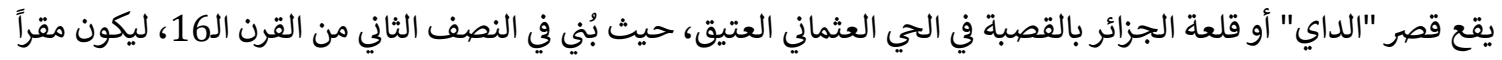

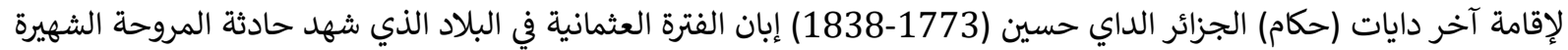
التي اتخذت ذريعة لاحتلال فرنسا للجزائر.

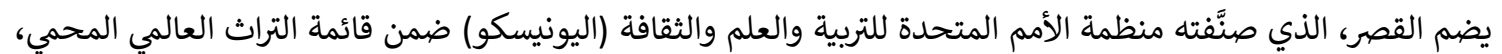

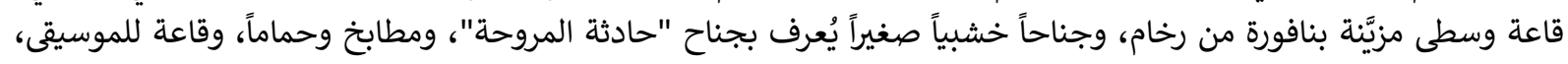
وجناح "الحريم"، وقاعة ديوان الحكم، ومخزناً للأسلحة.

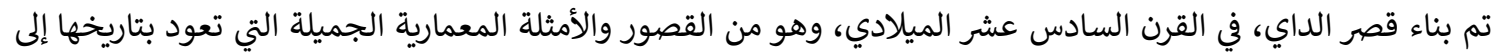

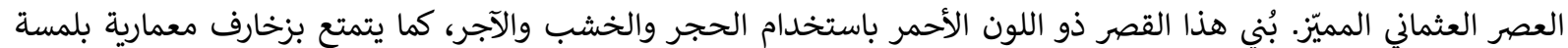

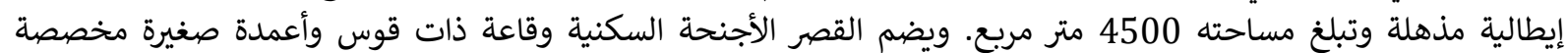

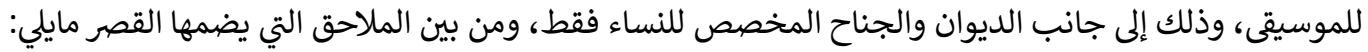

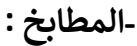

يحدها من الشرق مسجد الجيش، ومن الشمال ساحة قصر الداي، ومن الغرب جناح الحريم وحمامات الداي، من الجناء القناء

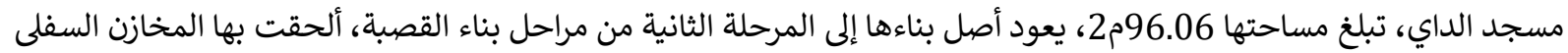

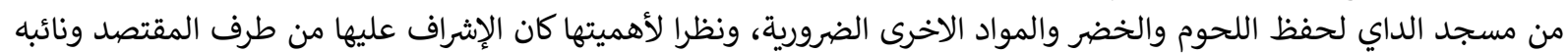

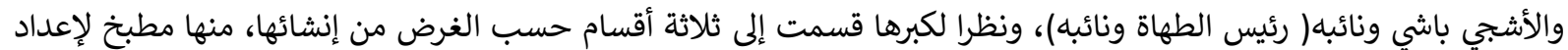

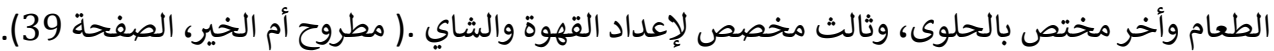

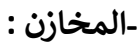

نجد خمسة مخازن تابعة للمطابخ، وتعود للمرحلة الأولى لمراحل بناء القلعة وتتكون من خمسة أقبية القبية رباعية الشكل

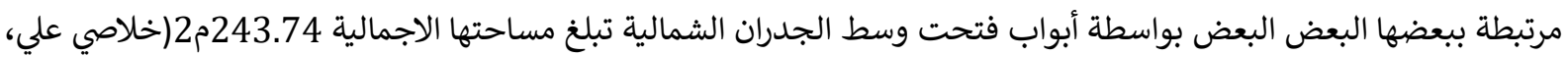

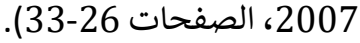

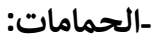

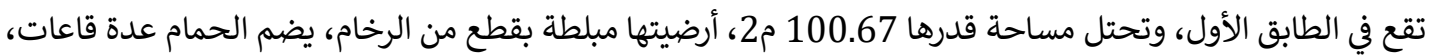

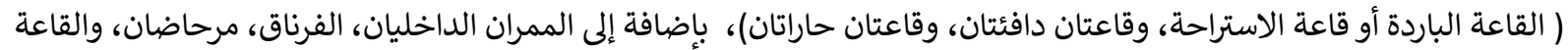
الباردة، وهي أكبر القاعات بالحمام تبارة تبلغ مساحتها

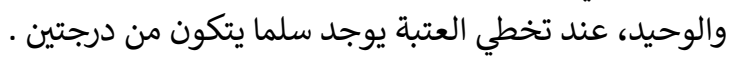

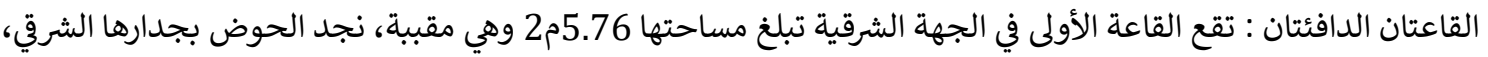

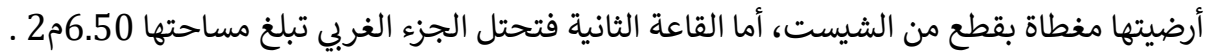

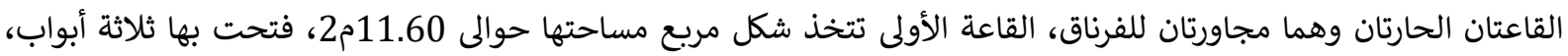

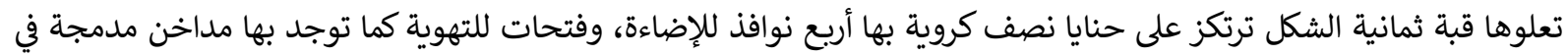

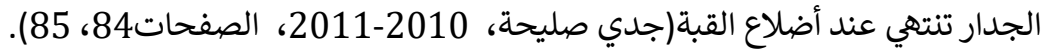

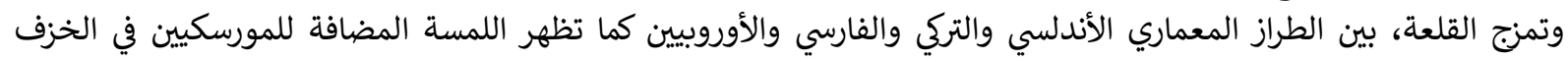
التونسي. - مالبيت الريفي

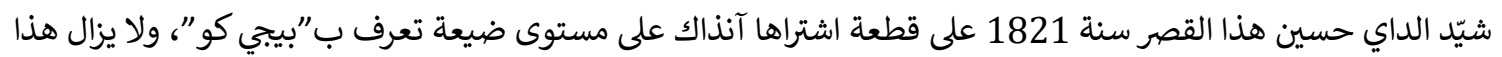

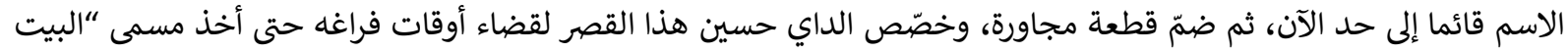

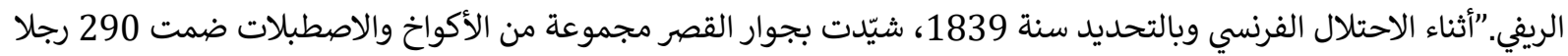

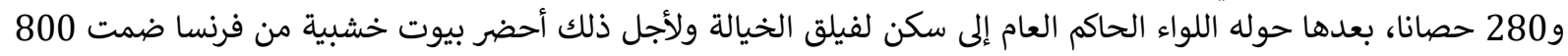

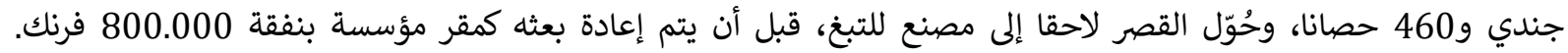
بعد الحرب العالمية الثانية، جرى تحويل القصر مجددا إلى ثكنة عسكرية للشرطة الفرنسية، إلى غائ إنى 
الاستقلال إلى مدرسة للشرطة الجزائرية، وفي سنة 1966 ألحق بثانوية عائشة أم المؤمنين، ثم جرى ضمّه إلى ثانوية الثعالبية.)

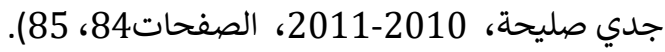

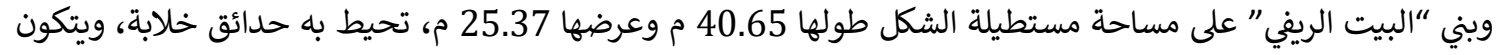

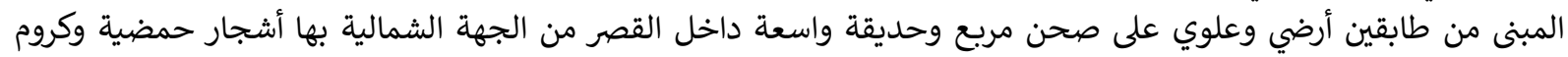
العنب، أما بالخارج فزين بأشجار المطاط وبعض وضئ ون النخيل.

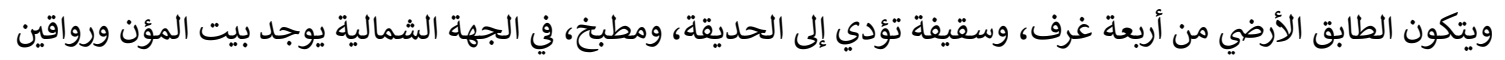

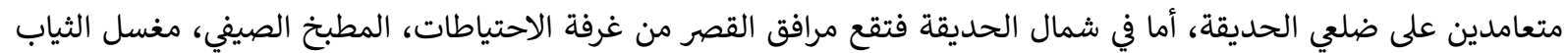

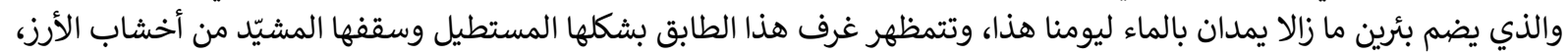

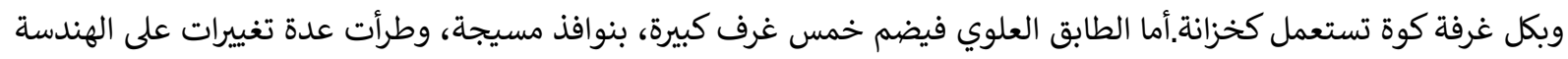

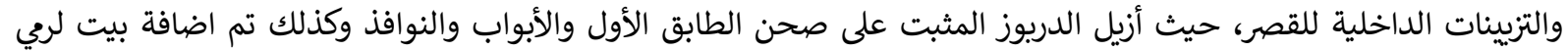

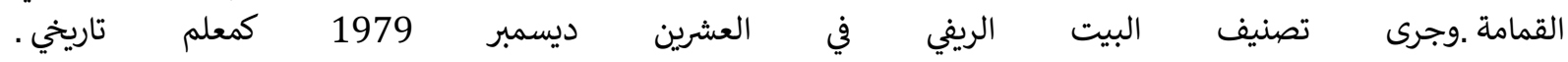

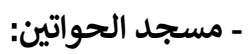

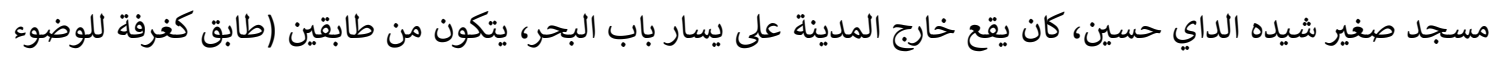

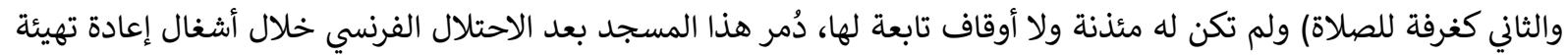

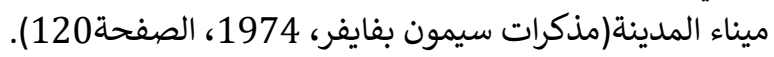
محل الصيد وجنان الدمرجي

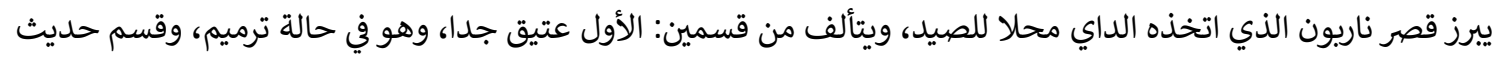

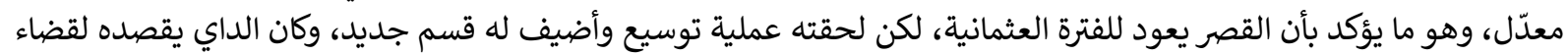
أوقات فراغه وممارسة هواية الصيد.

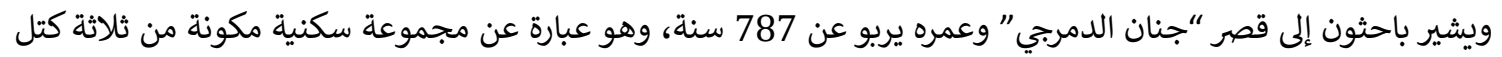

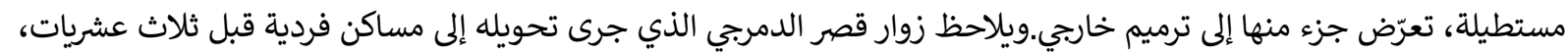

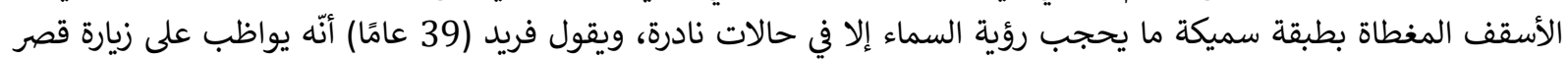

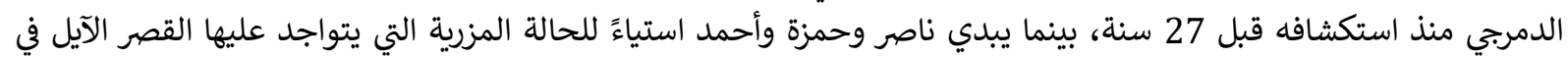
مجمله إلى الانهيار بسبب عدم الاعتناء بهذا المعلم.

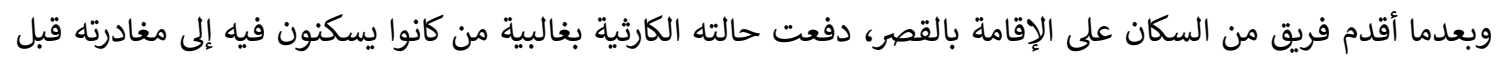

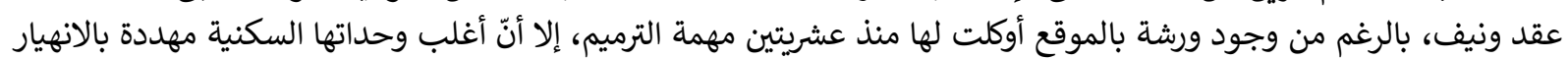
لقدمها وتآكها - نهاية حكم الداي حسين

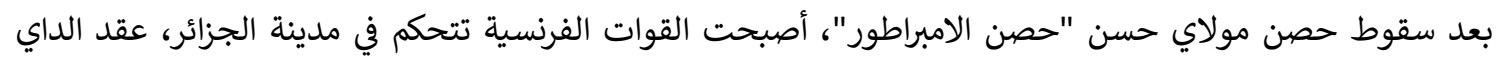

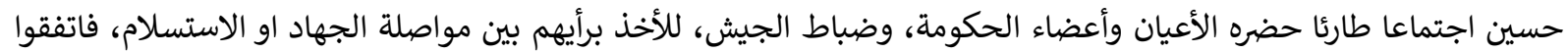

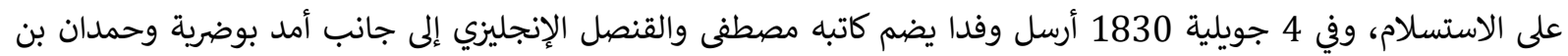

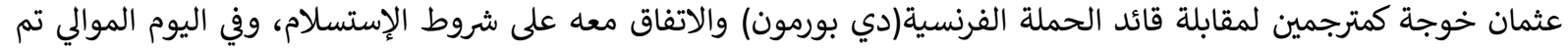

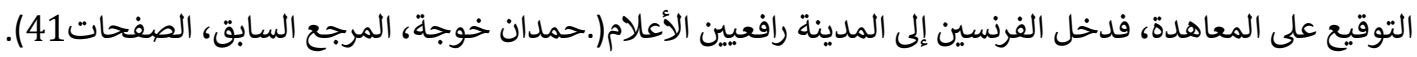

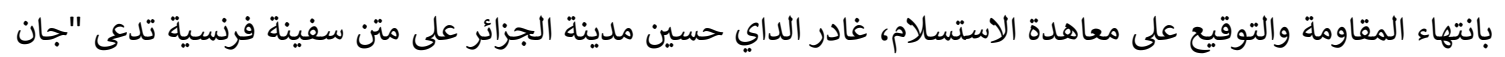

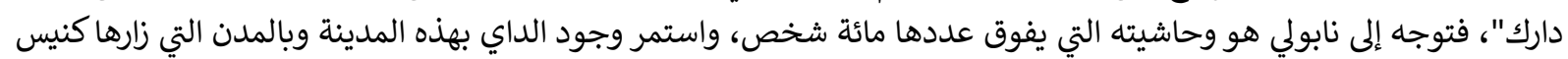

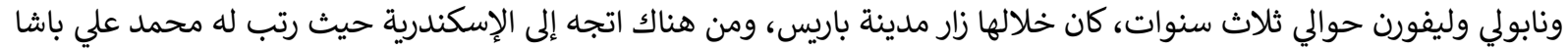

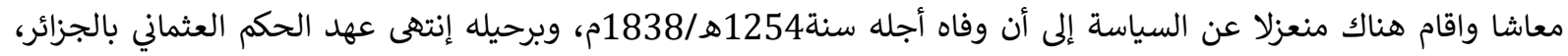

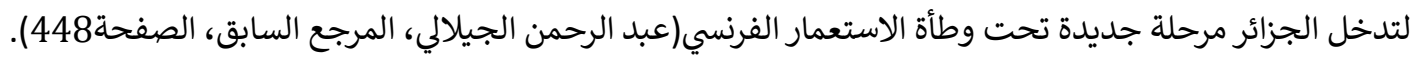




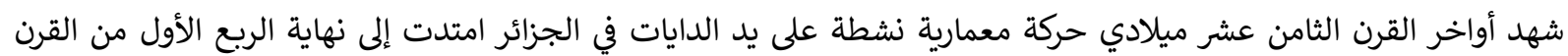

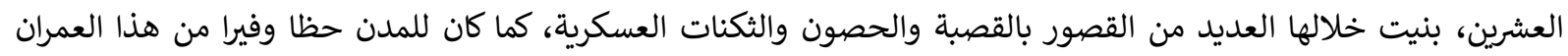

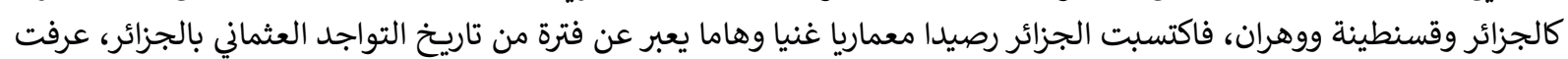

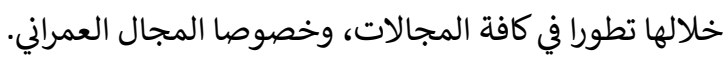

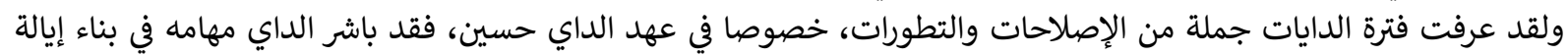

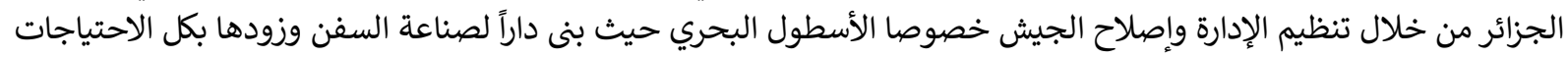

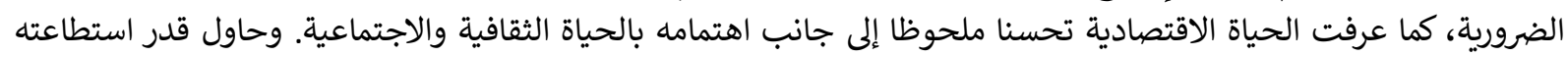
منع سقوط ايالة الجزائر بين أيدي الغزاة الفرونياة الفرنسيين.

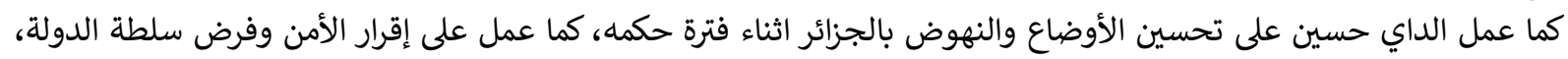

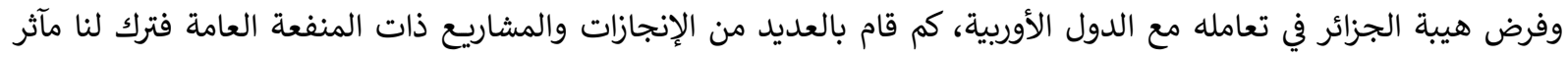

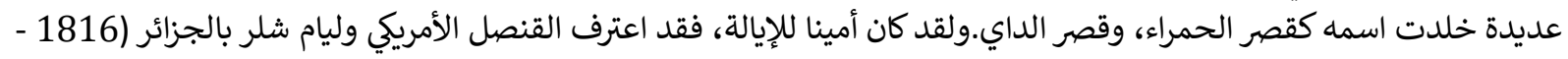

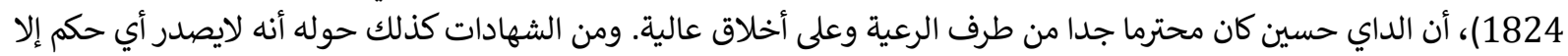

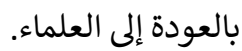




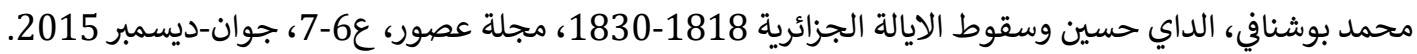

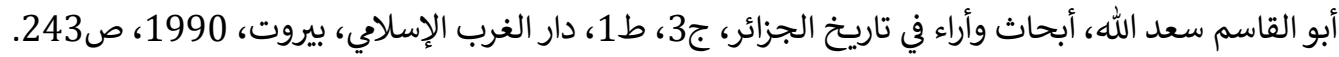

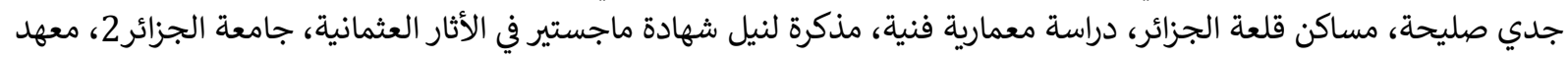
الأثار، 2010-2011 - 2010.

جمال الدين سهيل، ملامح من شخصية الجزائر خلال القرن 11هـ/2011م، 2011، مجلة الواحات للبحوث والدراسات، العدد 13،

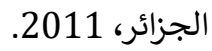

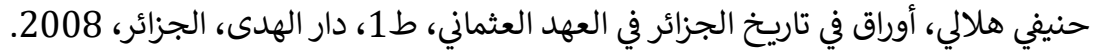

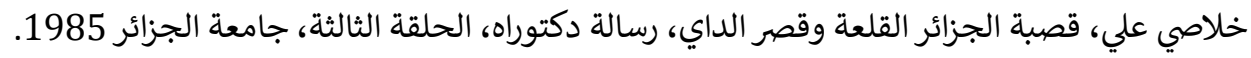

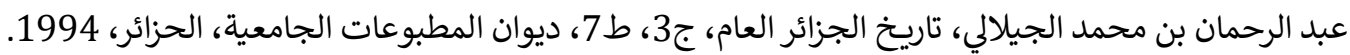

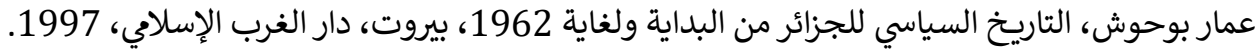

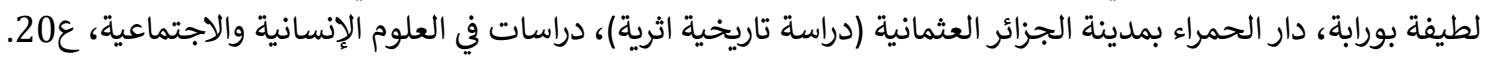

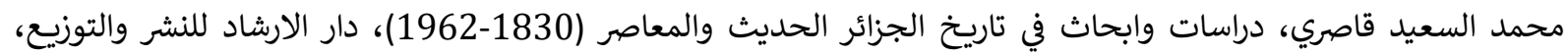

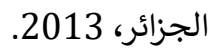

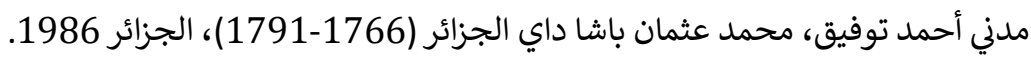

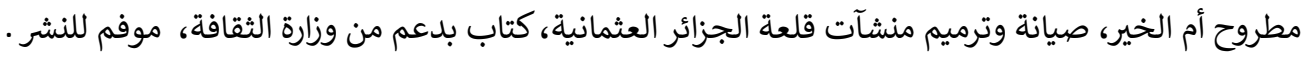

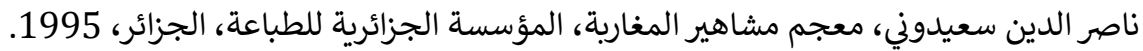

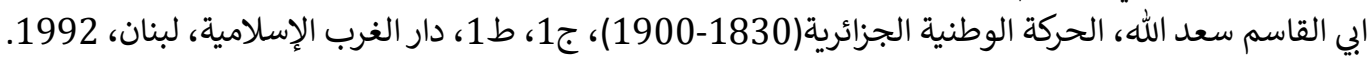

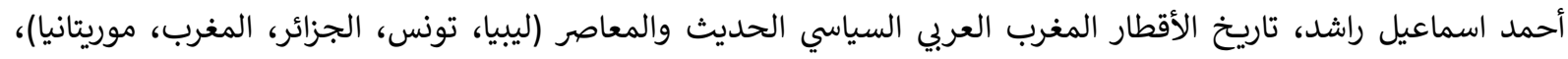

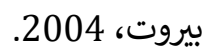

أحمد الشريف الزهار، مذكرات الحاج احمد الشريف الزهار نقيب أشراف الجزائر، ترجمة، احمد توفيق المدني، عالم المعرفة، الجزائر.

احمد الشريف الزهار، مذكرات الحاج احمد الشريف الزهار نقيب اشراف الجزائر، ترجمة أحمد توفيق المدني، عالم المعرفة،

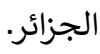

حسان كشرود، رواتب الجند وعامة الموظظفين وأوضاعهم الاجتماعية والاقتصادية بالجزائر العثمانية (1659-1830)، ماجستير

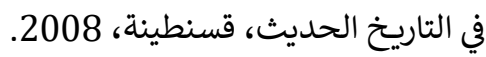

حسان كشرود، رواتب الجند وعامة الموظفين وأوضاعهم الاجتماعية والاقتصادية بالجزائر العثمانية من

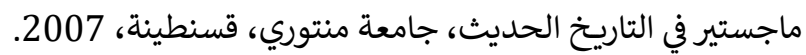

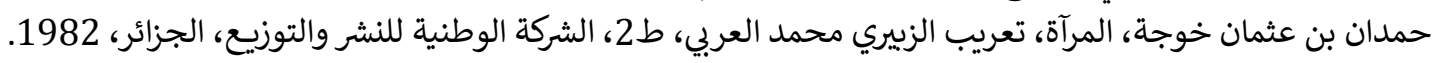

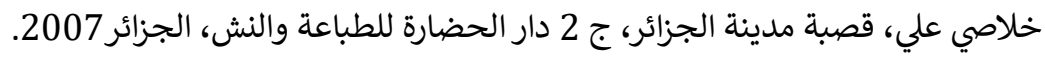

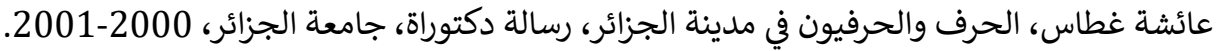

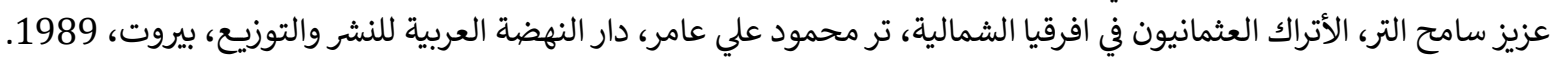

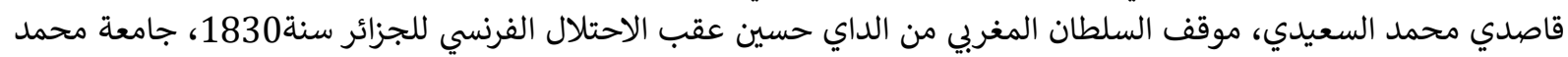
بوضياف، المسيلة.

محمد بوشافي، الداي علي خوجة واصلاحاته (1817-1818)، مجلة عصور، ع3، مخبر مصادر وتراجم، جامعة وهران1، جوان، 2003.

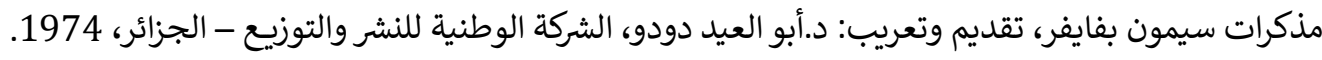

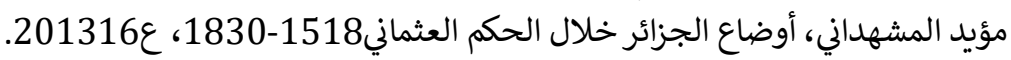

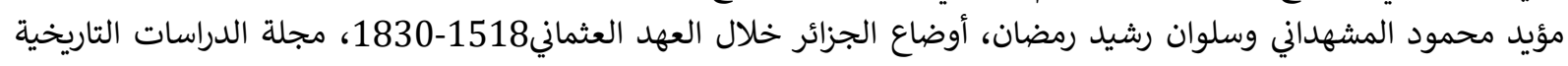

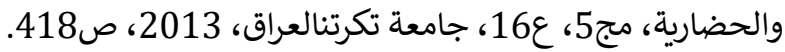

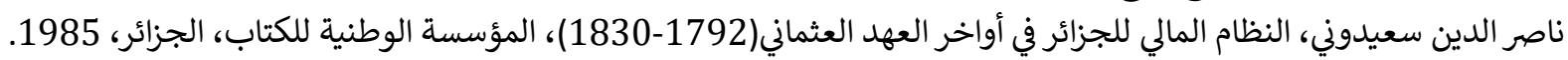

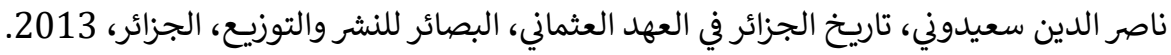

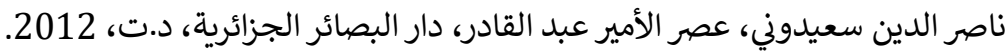

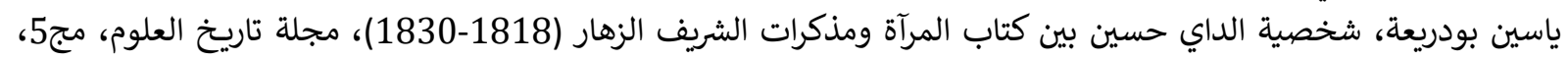

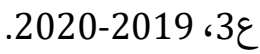


MONOTHEISM AND ITS IMPACT ON LAYING THE FOUNDATIONS OF SOCIETY(SURAT AL-IKHLAS AS A MODEL)

Mohaj Ghanem Abdel RAZZAQ \& Qahtan Mahboub FADIL 
II. International Congress of Humanities and Educational Research (IJHER Congress 2)

MONOTHEISM AND ITS IMPACT ON LAYING THE FOUNDATIONS OF SOCIETY(SURAT AL-IKHLAS AS A MODEL)

\author{
Mohaj Ghanem Abdel RAZZAQ ${ }^{1}$ \\ Qahtan Mahboub FADIL ${ }^{2}$
}

\begin{abstract}
:
Surat Al-Ikhlas is called Surat Al-Tawhid and in it is the declaration of God's oneness and his transcendence of what is not worthy of Him, acknowledgment with the tongue, and belief in the heart. This is the logic of faith and its essence Whoever does not believe in the oneness of God, and that he is the God and the Lord who has no partner, nor is there any equal or equal, he is not from the people of religion at all. and monotheism has many effects on the individual and society, including these effects:

Achieving true slavery.

Reducing the phenomenon of extremism and extremism.

Developing a culture of peaceful coexistence in society.

- Building people and urbanization.

and other important effects that aim to build and develop a sound society; By transforming a person into positive energy that builds and does not destroy, and gives more than it takes.

Key words: Monotheism, Compliance, Slavery, Distance From Extremism, Peaceful Coexistence.
\end{abstract}

http://dx.doi.org/10.47832/ijhercongress2-6

${ }^{1}$ Teaching at the Open Educational College, Iraq, hamody.tota2020@ gmail.com, https://orcid.org/0000-0001-7680-0539

${ }^{2}$ Teaching at Imam Azam College (University), Iraq, DoctorKahtan69@ gmail.com, https://orcid.org/0000-0001-8824-9748 


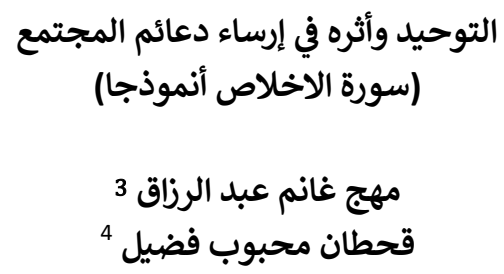

الملخص:

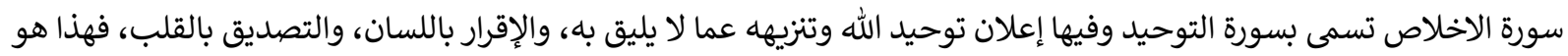

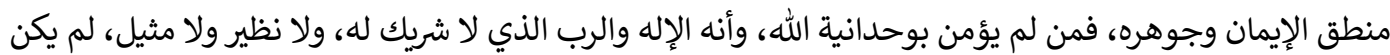
من أهل الدين على الإطلاق.. وللتوحيد آثار عديدة على الفردية الفرد والمجتمع ومن هذه الاثار: - تحقيق العبودية الحقة. - م- الحد من ظاهرة الغلو والتطرف. - تنمية ثقافة التعايش السلمي في المجتمع.

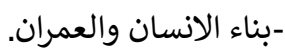

وغيرها من الآثار المهمة التي تهدف إلى بناء المجتمع بناءً سليماً وتطويره؛ بتحويل الانسان إلى طاقة ايجابية تبني ولا تهدم، وتعطي

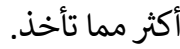
الكلمات المفتاحية: التوحيد، الامتثال، العبودية، البعد عن التطرف، التعايش السلمي.

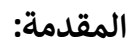

إن المجتمع لابد له من دعائم مادية ومعنوية يبنى عليها ويقدر ما تكون هذه الدعائم قوية يكون المجتمع قوياً، ومن أهم هذه الدعائم المعنوية وأهمها التوحيد. ولخلق مجتمع متسامح وقوي ومتعاون لأهو لابد ل(لا إله الا الله) أن تترسخ في أذهان الافراد صغيرهم وكبيرهم، ف (لا إله الا الله) تعني لا معبود ولا حاكم ولا قوة ولا طاعة الا لله.

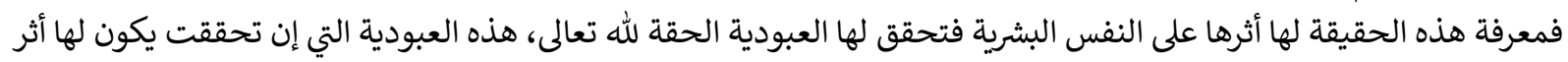

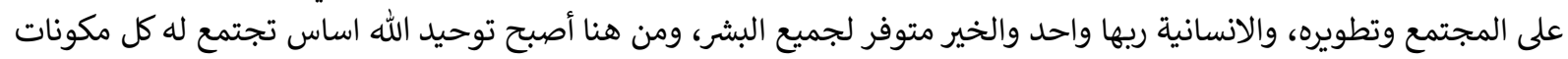

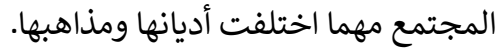

خطة البحث:

يتضمن البحث مقدمة ومبحثين وخاتمة المبحث الأول (سورة الاخلاص تفسيرا ومعنى) ويتضمن ومندئن المطالب الب الاتية:

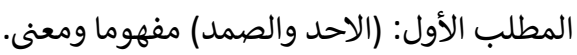

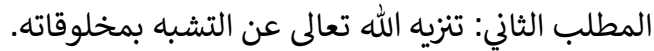

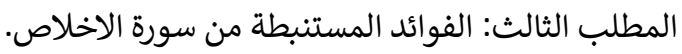

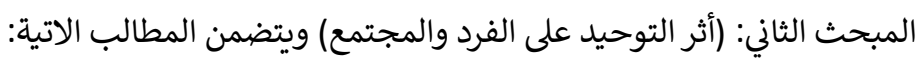
المطلب الأول: تحقيق العبودية الحقة.

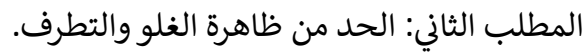

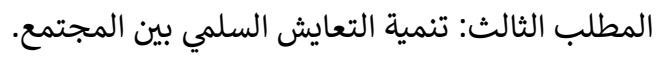
المطلب الرابع: بناء الانسان والعمران. والخاتمة التي اوجزت فيها أهم النتائج التي توصلت التئن اليها. 


\section{المبحث الأول: (سورة الاخلاص تفسيرا ومعنى) المطلب الأول: الاحد والصمد مفهوما ومعنى}

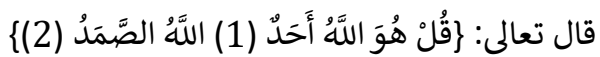

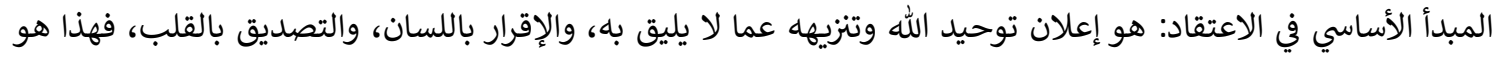

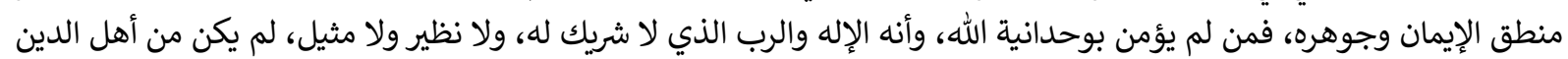

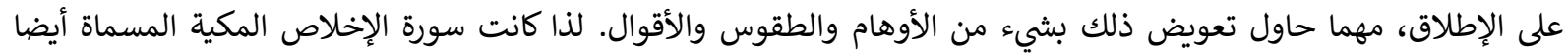

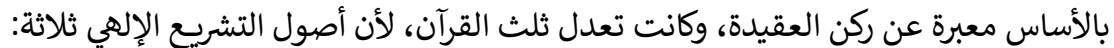

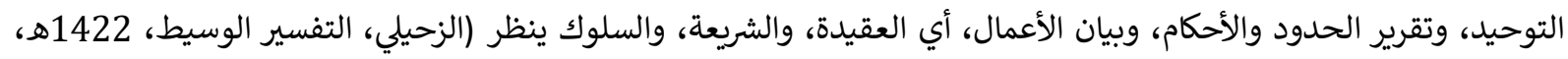
صفحة 3 / (2957)

عن أبي سعيد الخدري، أن رجلا سمع رجلا يقرأ: قل هو الله أحد يرددها، فلما أصبح جاء إلى رسول الهال اللها الله (صلى الله عليه

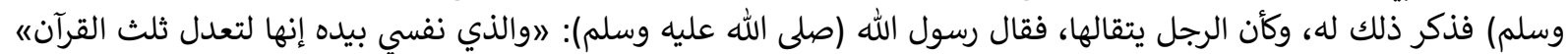

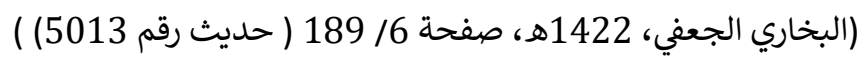

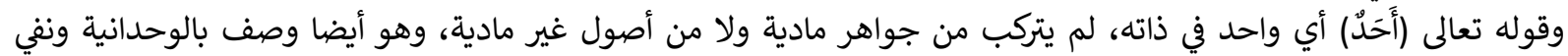

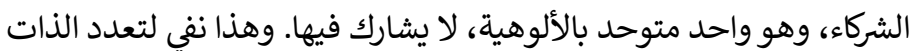

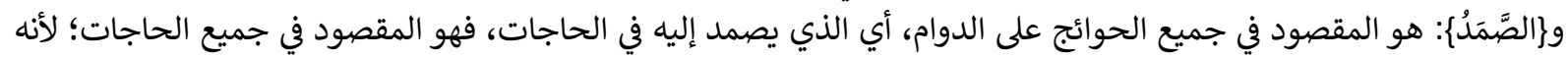

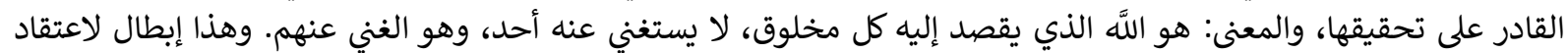

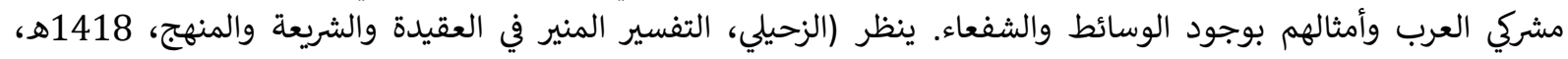
الصفحات (465-464) (405).

\section{المطلب الثاني \\ تنزيه الله عن التشبه بمخلوقاته}

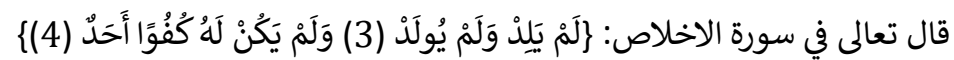

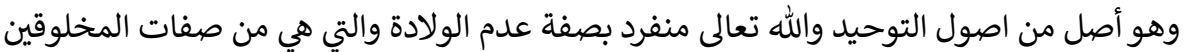

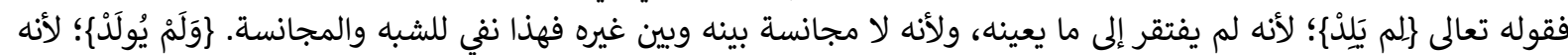

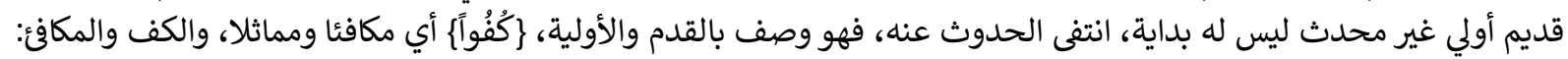

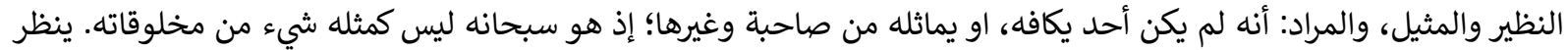

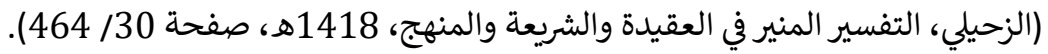

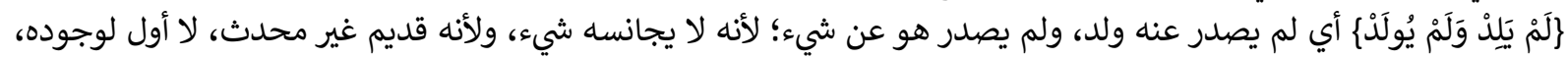

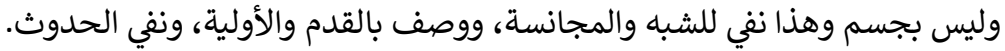

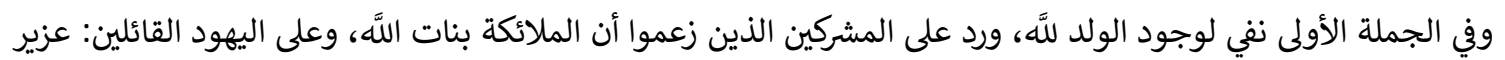

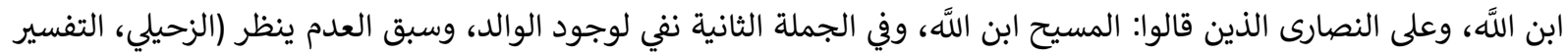

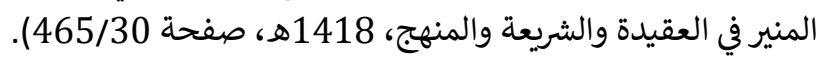

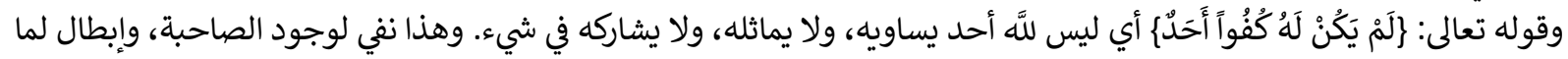

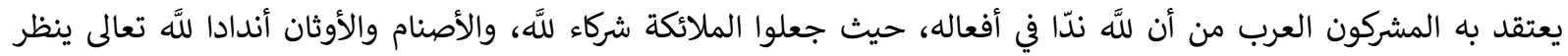

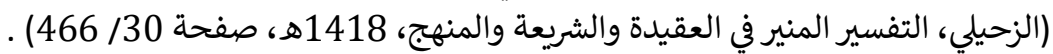

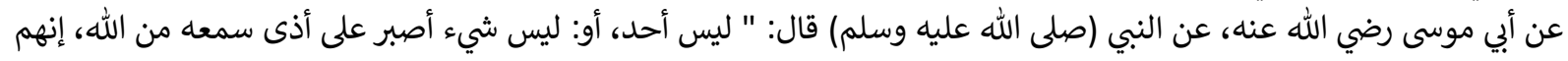

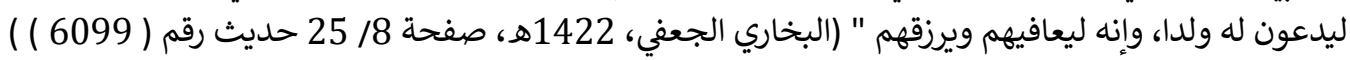




\section{المطلب الثالث

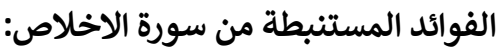

هناك العديد من الفوائد المستوحاة من سورة الاخلاص، وقد ذكر الامام الرازي بعضا منها:

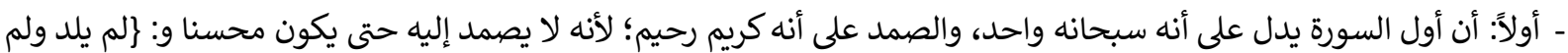

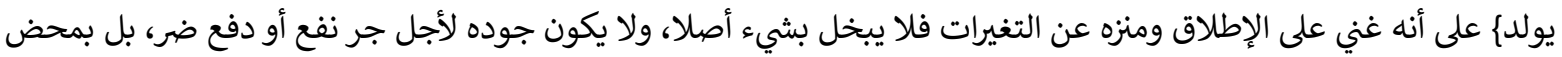

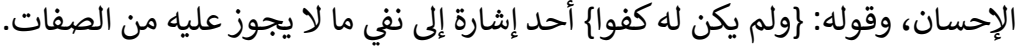
- الفائدة الثانية: قوله تعالى:

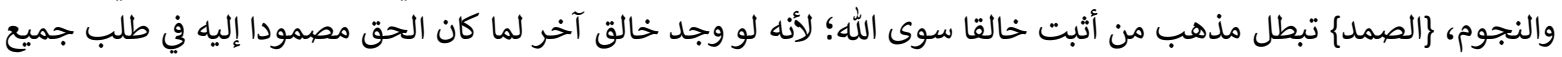

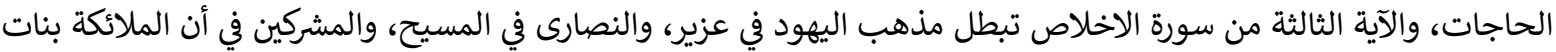

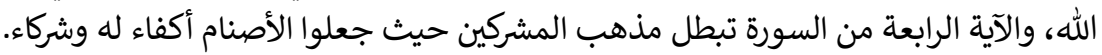

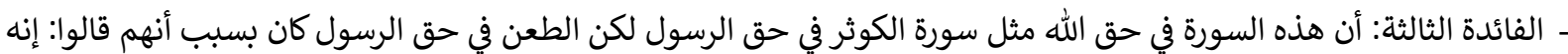

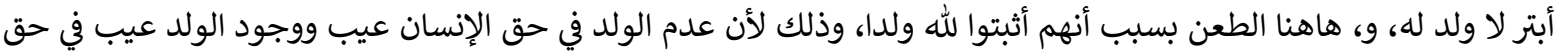

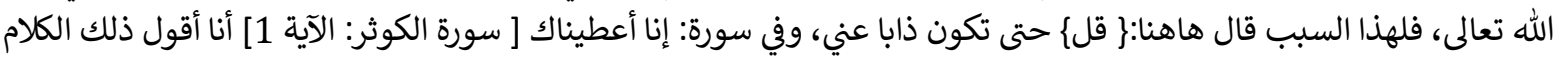

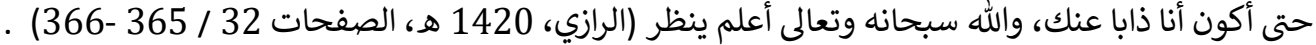




\section{المبحث الثاني: (أثر التوحيد على الفرد والمجتمع):

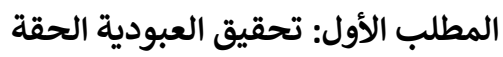

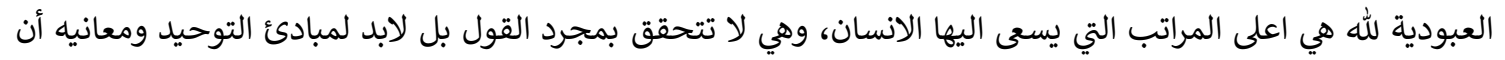

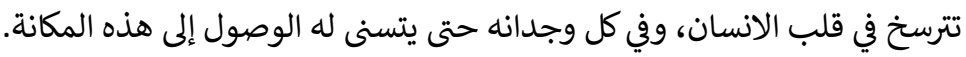

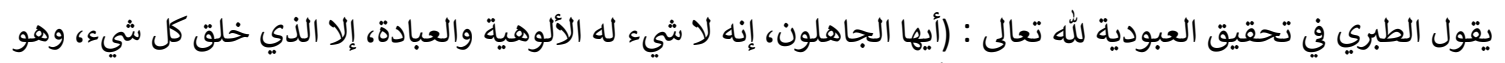

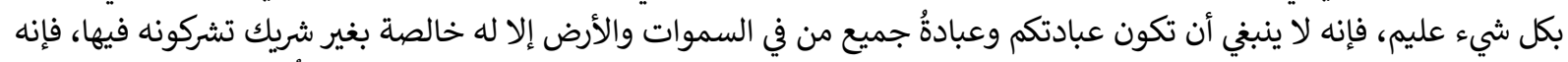

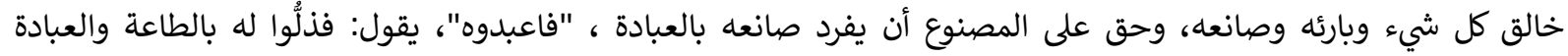

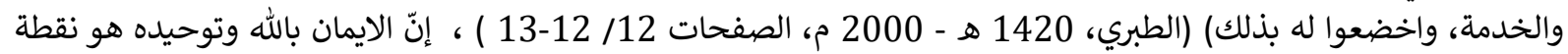

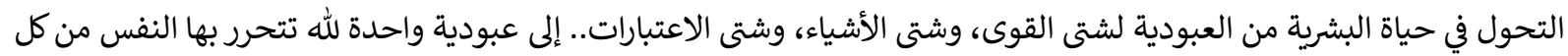

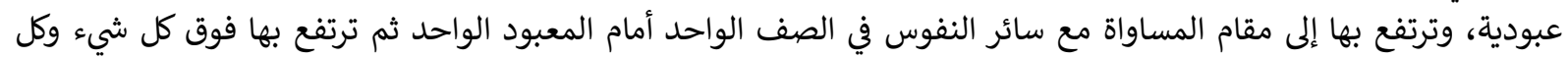

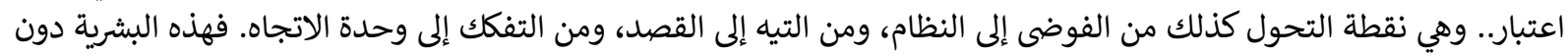

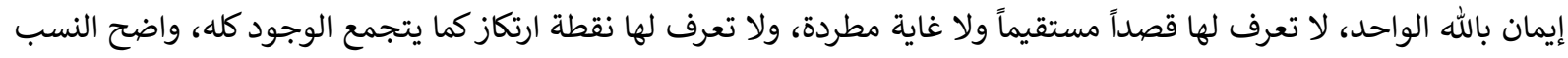

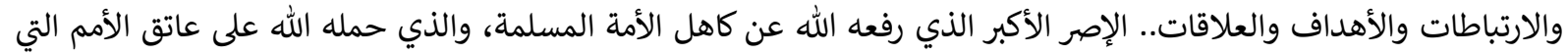

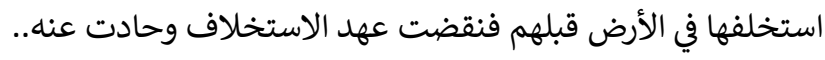

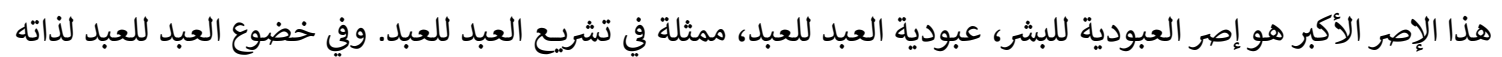

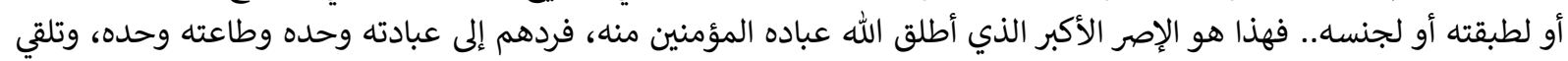
الشريعة منه وحده.

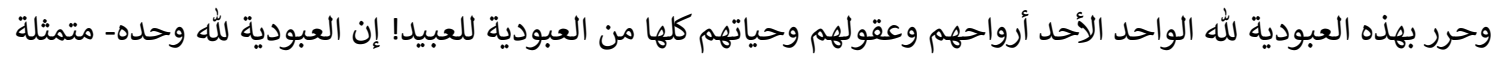

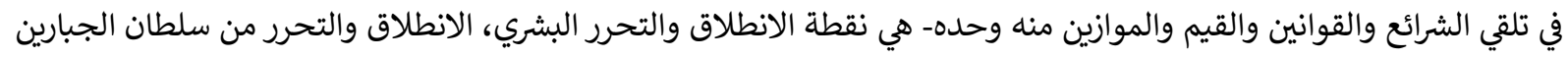

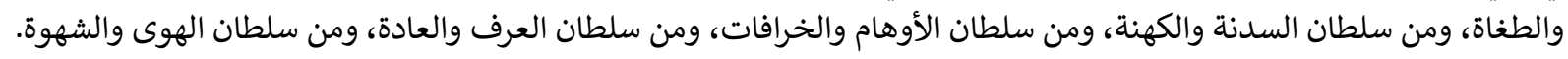

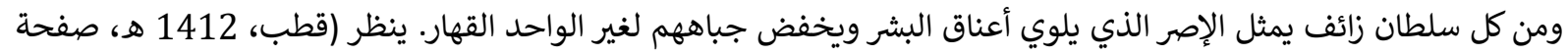

.

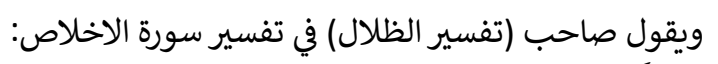

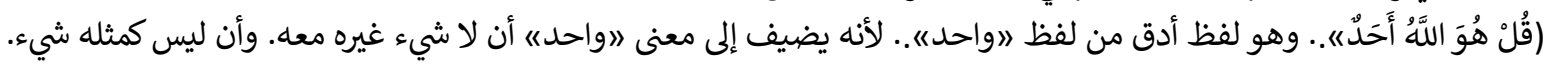

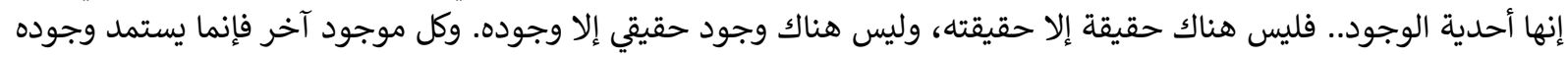

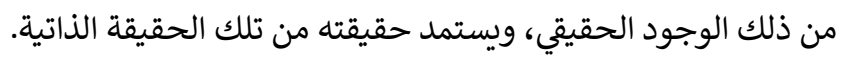

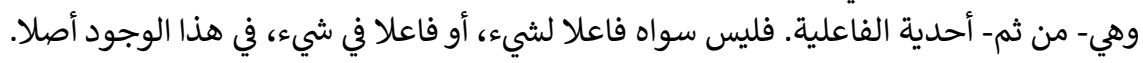

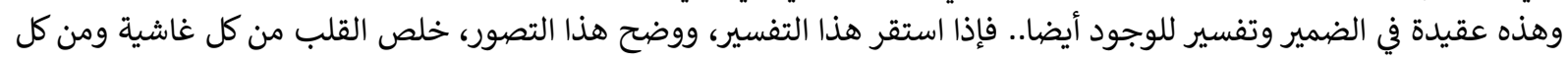

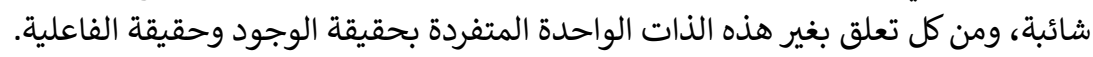

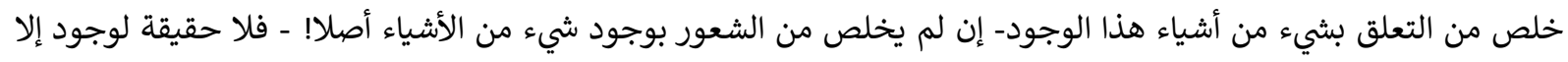

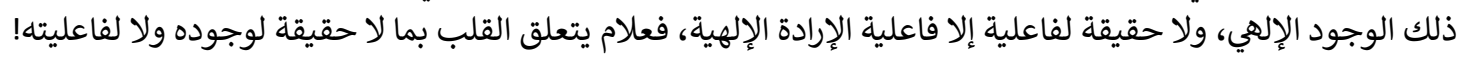

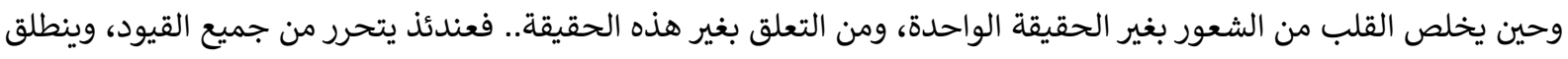

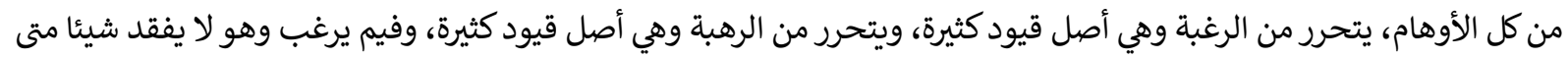

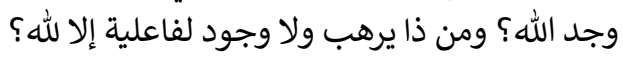

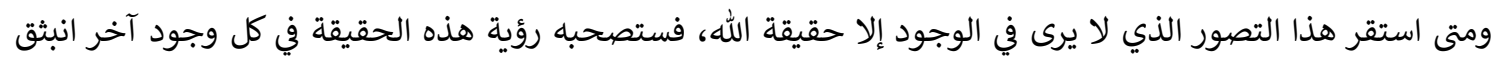

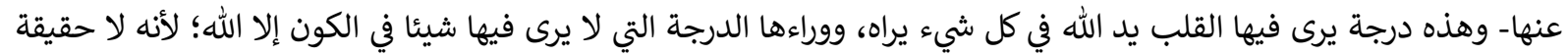
هناك يراها إلا حقيقة الله.

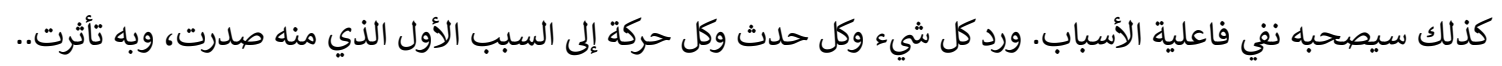

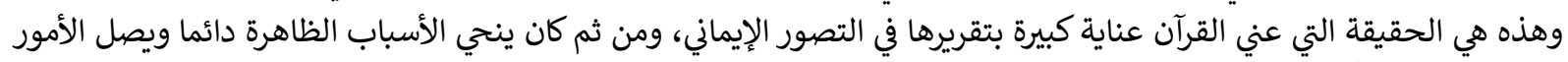

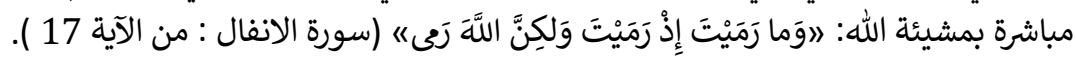

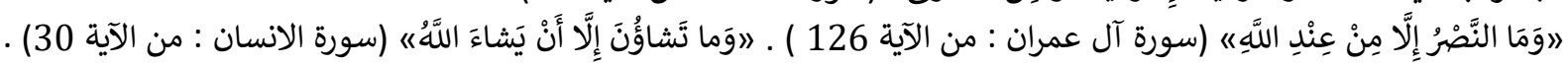
وغيرها كثير.. 


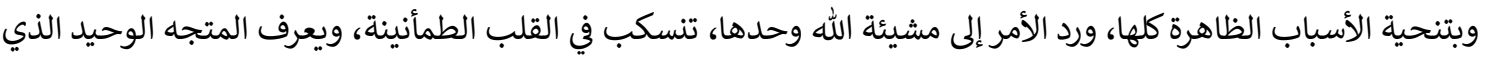

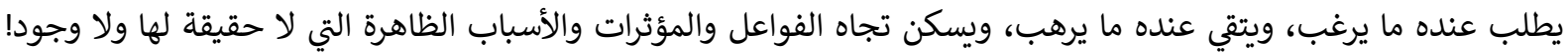

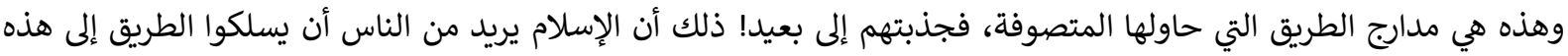

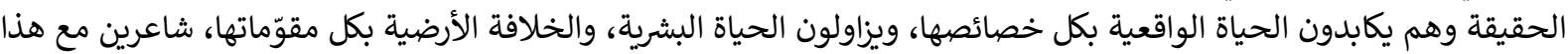

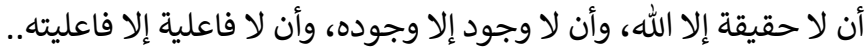

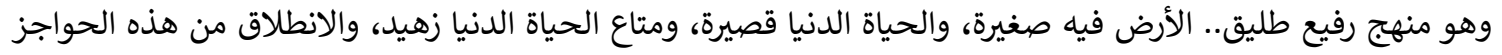

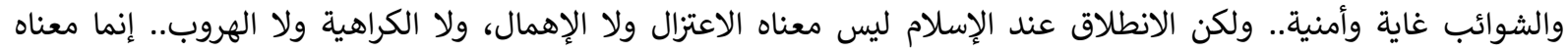

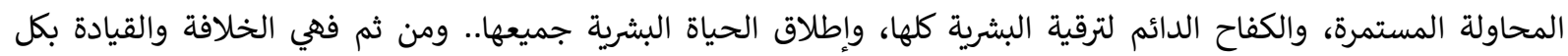
أعبائهما، مع التحرر والانطلاق بكل مقوماتهما. كما أسلفنا.

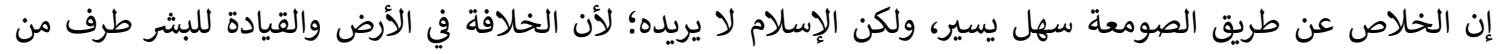

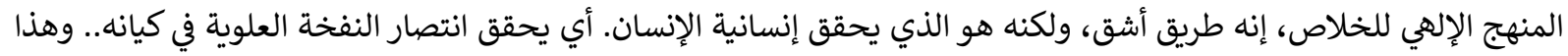

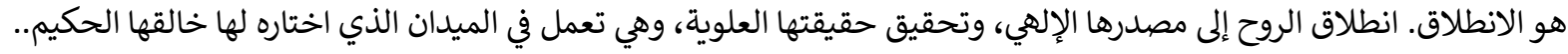

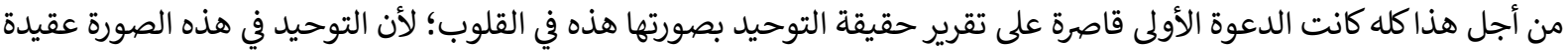

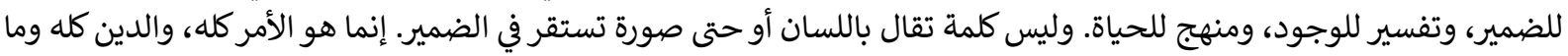

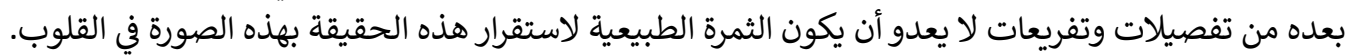

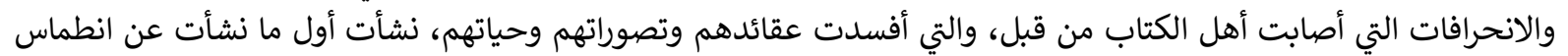

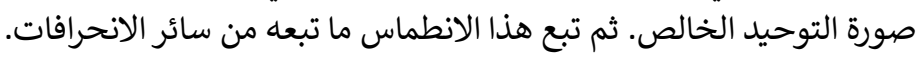

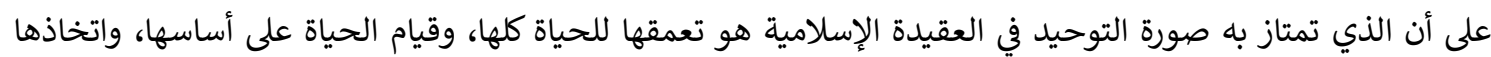

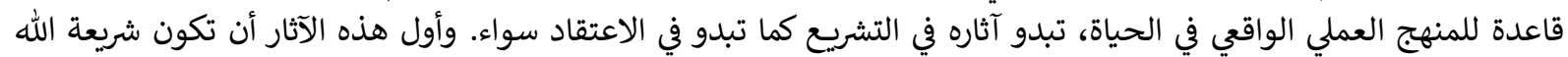

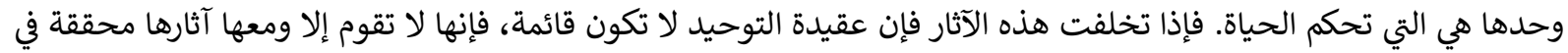

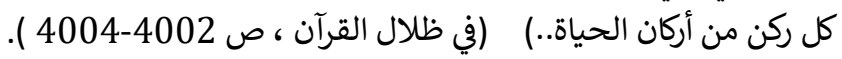

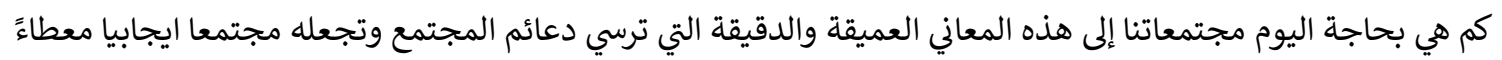

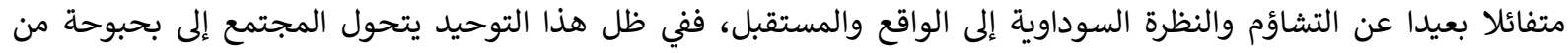

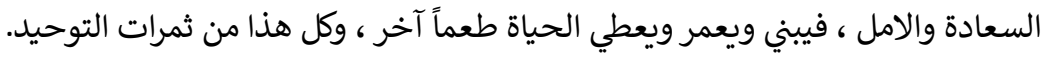

\section{المطلب الثاني \\ الحد من ظاهرة الغلو والتطرف}

التوحيد يضبط مشاعر الانسان وسلوكه فيتوازن في أقواله وأفعاله وجميع تصرفاته بعيدا عن التشنج والغلو والتطرف فالغلو لغة: غلو: غلا السعر (يغلو) غلاء.

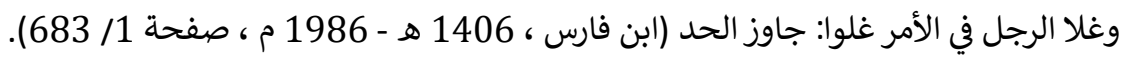

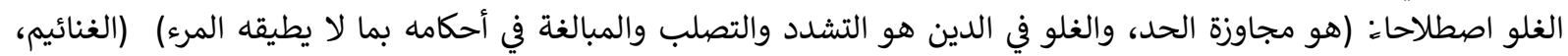

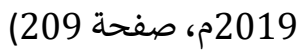

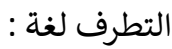

من الطرف: بمعنى طرف الشيء (ابن فارس ، 1406 هـ - 1986 م ، صفحة 1 1/ 594 مادة ( الطاء والتاء وما يثلثهما ))

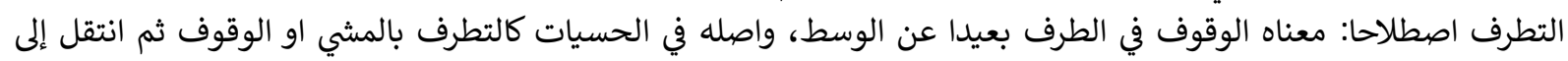

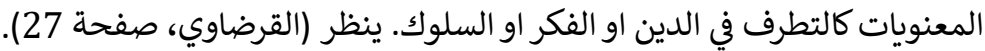

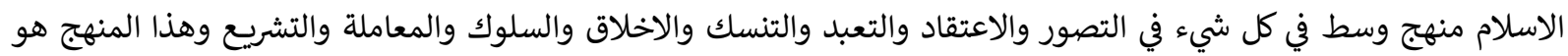

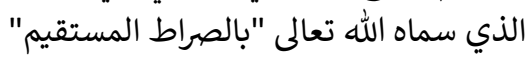

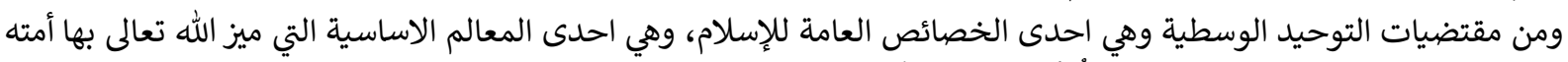

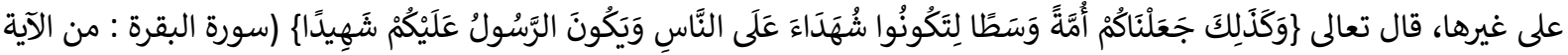

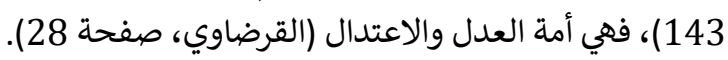


هناك أربعة عوامل اساسية مسببة لظهور الغلو والتطرف:

$$
\text { - }
$$

- - -وجود انظمة حكم متطرفة تمارس العنف (حسن، 2015، صفحة 266/عدد313).

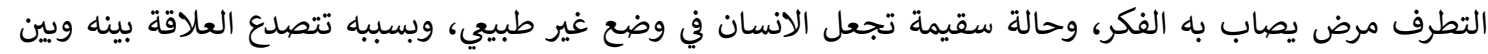

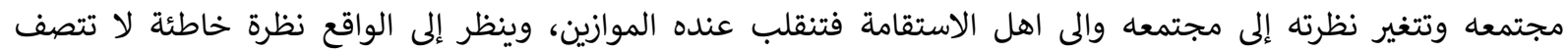

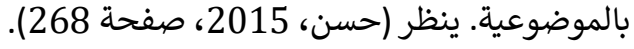

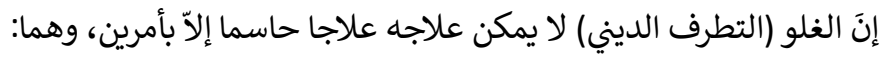

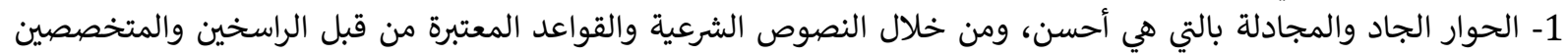

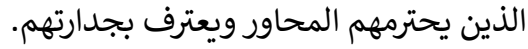

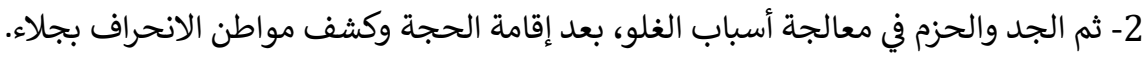

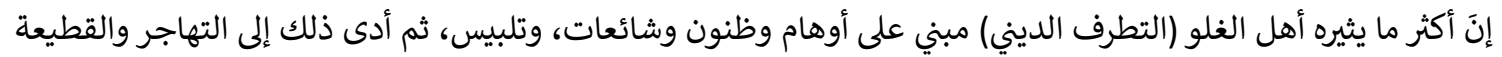

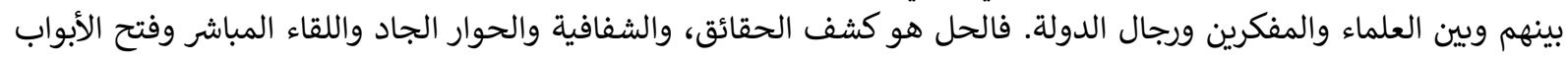

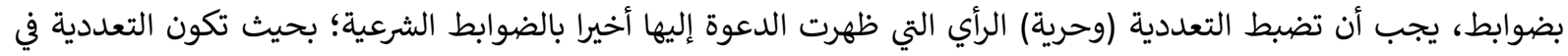

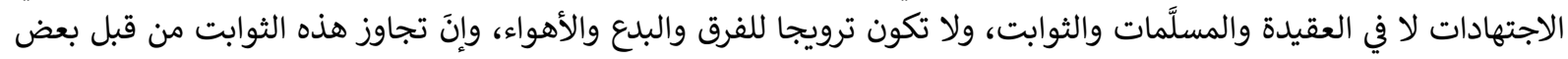

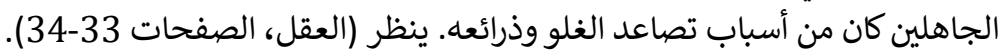

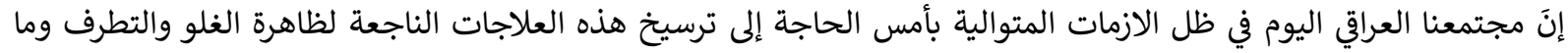

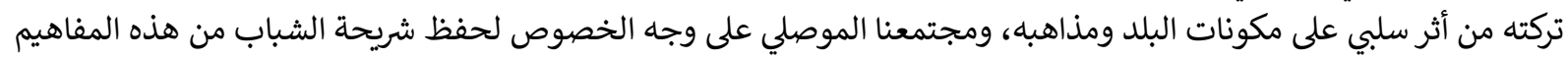
المنحرفة للدين والحياة.

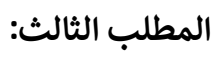

\section{تنمية ثقافة التعايش السلمي في المجتمع}

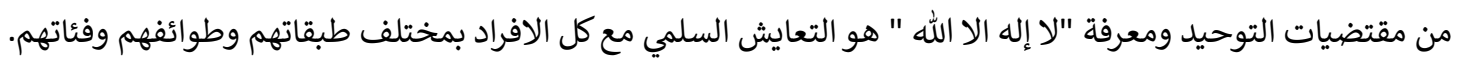

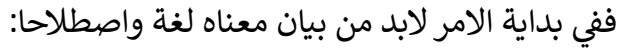
ففي الرجوع إلى الدلالة اللغوية لمصطلح التعايش نجد أن (تعايشوا) عاشوا على الالفة والمودة ومنه التعايش السَلميَ، (عايشه) عاش معه. (العيش) معناه الحياة وما تكون به الحياة من المطعم والمشرب والدخل والخبز، ينظر (مصطفى، الزيات، عبد القادر، و واخرون،

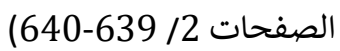
تعريفه اصطلاحاء هو من المصطلحات الحدات الحيثة التي ظهرت عام 1922 م ويقصد بها: احترام الاخرين وحرياتهم والاعتراف بهم

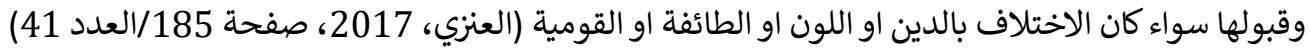

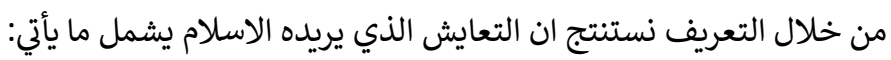
1 - 20 - 20تح افق للحوار وقبول الاخر.

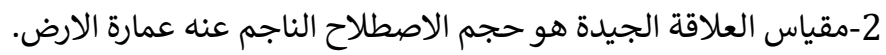

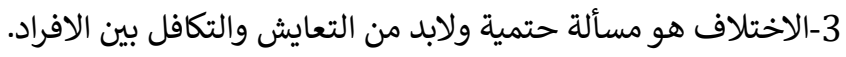

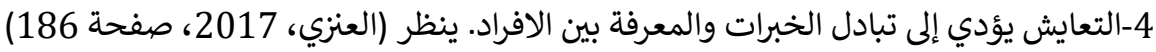

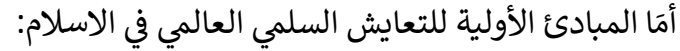

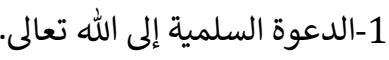
2-مجادلة الخصوم بالتي هي أحسن. 3-علاقة المسلمين بغيرهم من الامم والشعوب آحسن هي علاقة سلم لاحرب.

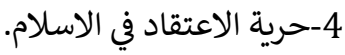
5- العدل والمساوة بين الناس كافة. 
وهذه المبادئ توصد ابواب الفتن والطائفية وتدعو إلى أن يعيش الناس حياتهم في سلم وأمان. ينظر (المطعني، 1996،

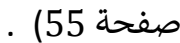

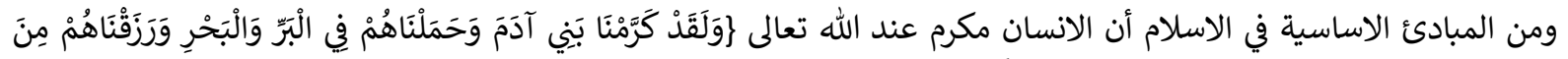

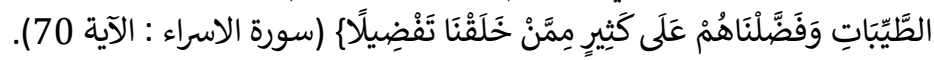

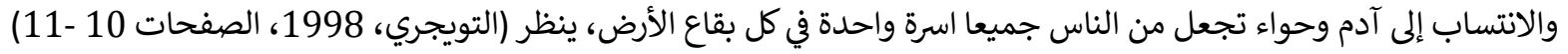

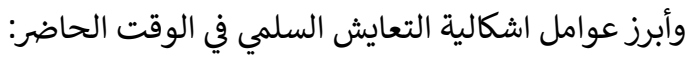

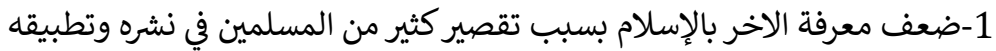

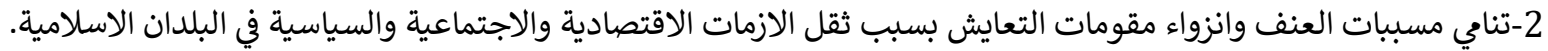

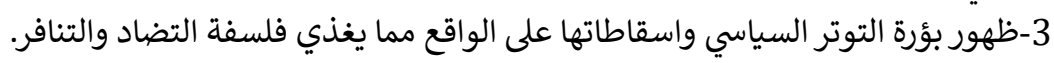

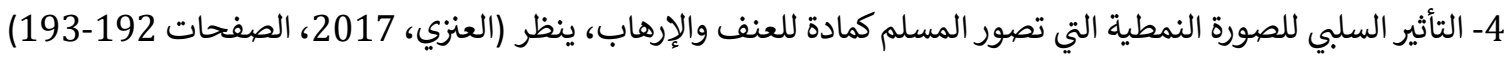

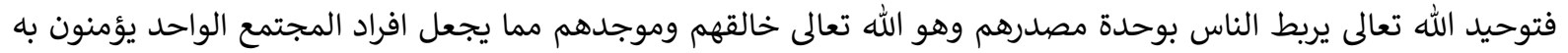

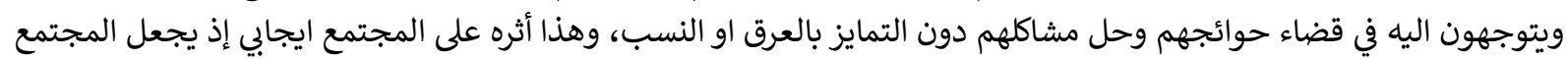

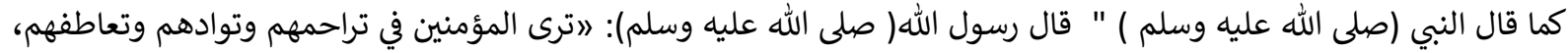

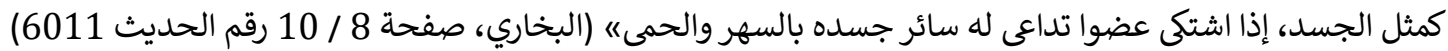

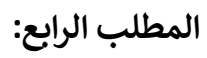

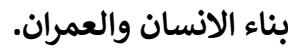

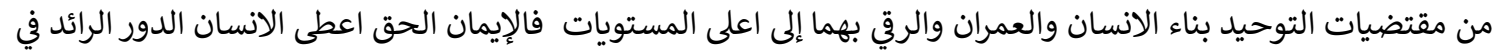
الارض وخلافتها وهو دور مركزي في نظام الكون كله يمنحه مجان الا واسعا للفان العاعلية والعمل والتألتأثير.

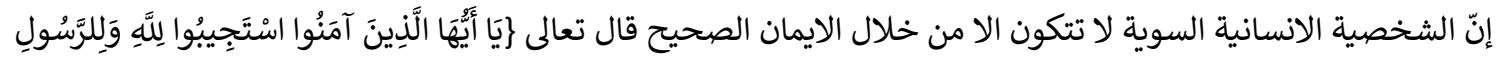

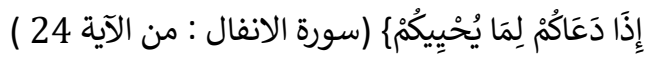

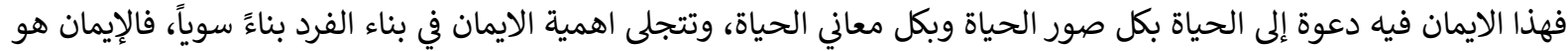

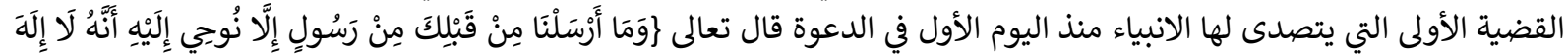

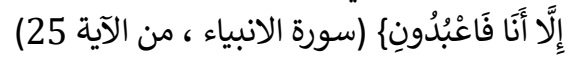

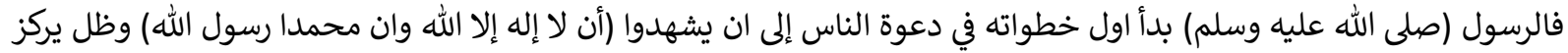

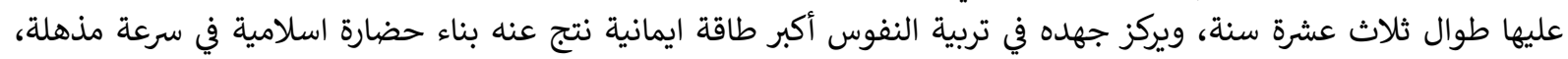

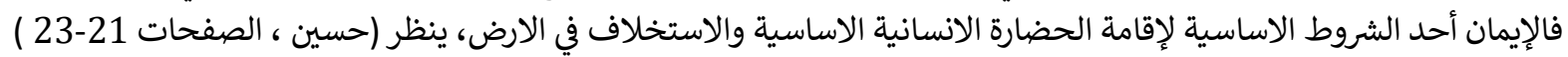

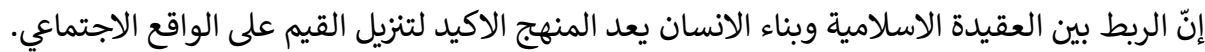

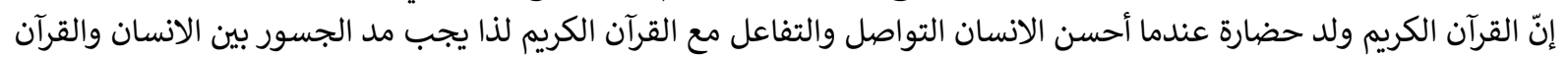
من جديد.

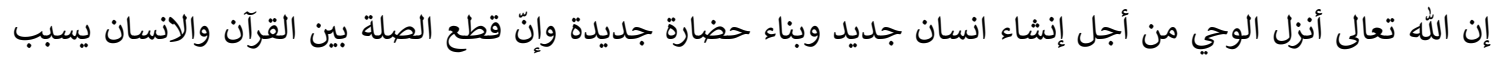
فوضى عارمة تعم كل مكان، يوكد القرآن الكريم على قيمة عمارة الارض وأنها عبادة موجبة، ينظر (الخطيب، صفحة التهان (almerja.com

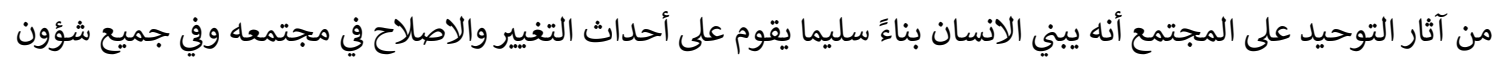

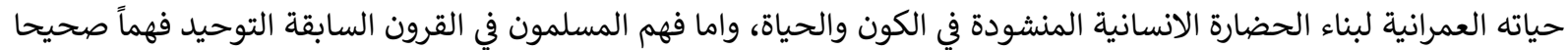
وايجابياً بنوا حضارة وعمران لازالت المجتمعات تتغنى بها وتستفيد من خبرتها وتجاريها. 
II. International Congress of Humanities and Educational Research (IJHER Congress 2)

الخاتمة

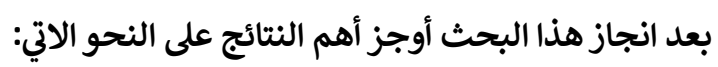

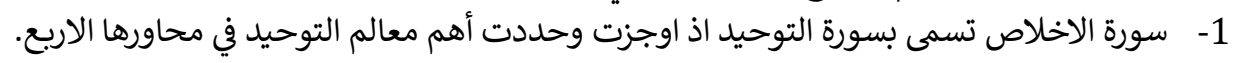

2- - فهم التوحيد فهماً صحيحاً كما صورته السورة يرسم الطريق الواضح فيد في بناء الانسان بناءً صحيحا، وفهم الكون والحياة

فهما ايجابيا

3- من اثار التوحيد على الفرد والمجتمع تحقيق معنى العبودية الخالصة لله تعالى.

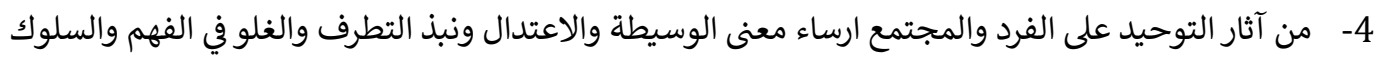

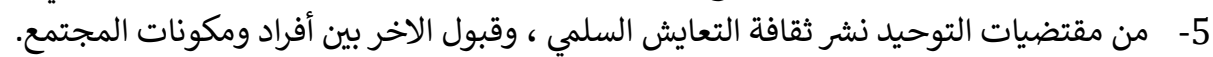

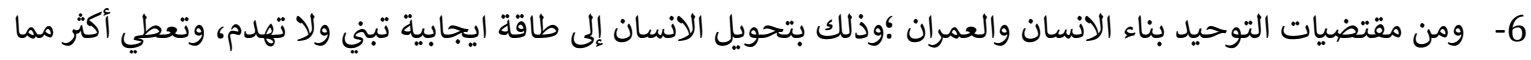

تأخذ.

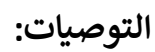

أوصي المؤسسات التريوية والتعليمية الاهتمام بتدريس سورة الاخلاص في كافة المراحل ، والتركيز على بيان أهدافها، واهميتها في

بناء الفرد والمجتمع ألموسات الترب 
ابراهيم مصطفى، احمد الزيات، و حامد واخرون عبد القادر • (بلا تاريخ). المعجم الوسيط، مجمع اللغة العربية في القاهرة. دار الدعوة.

احمد بن فارس بن زكرياء القزويني الرازي ابو الحسين (ت:395هـ) ابن فارس • (1406 هـ - 1986 م ). مجمل اللغة لابن فارس (المجلد 2). بيروت: مؤسسة الرسالة.

احمد رشيد حسين · (بلا تاريخ). السنن الالهية في بناء الحضارات في القرآن الكريم (دراسة موضوعية )، بحث.

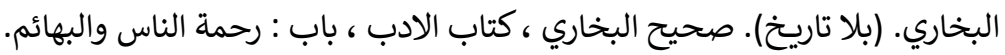

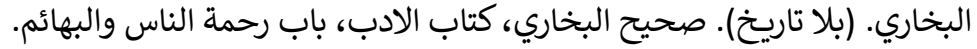

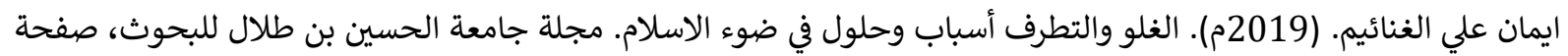
206

بو عبد الله محمد بن عمر بن الحسن بن الحسين التيمي فخر الدين خطيب الري (ت:606هـ) الرازي. (1420 هـ). مفاتيح الغيب

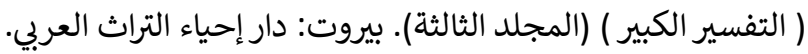

سورة آل عمران : من الآية 126 ـ (بلا تاريخ). سورة الاسراء : الآية 70. (بلا تاريخ). سورة الانبياء ، من الآية 25. (بلاء تاريخ).

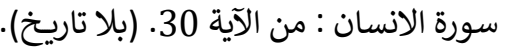
سورة الانفال : من الآية 17 ـ (بلان تاريخ). سورة الانفال : من الآية 24 ـ (بلا تاريخ). سورة البقرة : من الآية 143. (بلا تاريخ).

سيد (ت:1385هـ) قطب. (1412 هـ). في ظلال القرآن. بيروت- القاهرة: دار الشروق. عبد العزيز بن عثمان التويجري. (1998). المنظمة الاسلامية للتربية والعلوم الثقافية ـ الاسلام والتعايش بين الاديان في افق القرن الحادي والعشرين، (الصفحات 10 -11).

عبد العظيم ابراهيم المطعني. (1996). مبادىء التعايش السلمي في الاسلام (منهجا وسيرة ). القاهرة: دار الفتح للأعلام العربي.

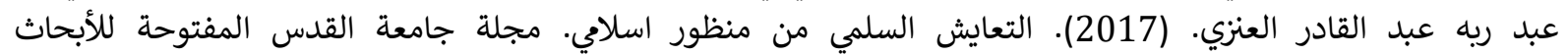

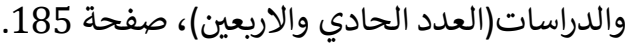

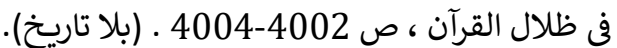
محمد النصر حسن. (2015). التربية الوقائية للمؤسسات التربوية في مواجهة التطرف الفران الفكري. مجلة دراسات في التعليم الجامعي ، صفحة 266.

محمد بن اسماعيل أبو عبد الله البخاري الجعفي. (1422هـ). الجامع المسند الصحيح المختصر من أمور رسول الله صلى الله

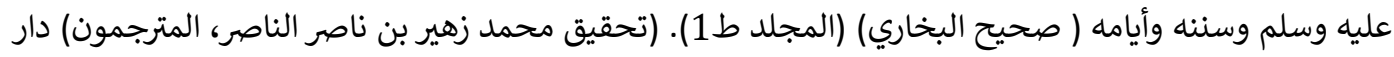
طوق النجاة.

محمد بن جرير (ت: 310هـ) الطبري. (1420 هـ - 2000 م). جامع البيان في تأويل القرآن (المجلد 1). مؤسسة الرسالة. مواهب الخطيب. (بلا تاريخ). البناء الحضاري للإنسان وفق منهج القرآن. almerja.com. تم الاسترداد من almerja.com.

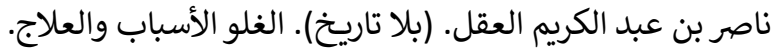

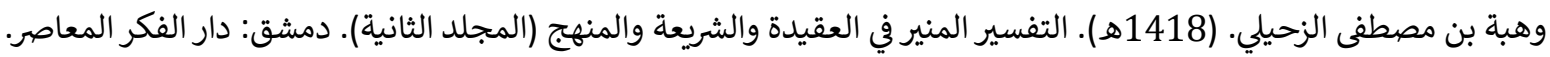

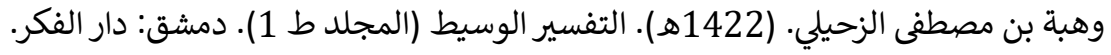
يوسف القرضاوي. (بلا تاريخ). الصحوة الاسلامية بين الجحود والتطرف (المجلد 12). 
WAYS TO ADDRESS THE WATER CRISES AND ACHIEVE WATER SECURITY (WATER DIPLOMACY AS A MODEL)

Layla Ashour Hajim AL-KHAZRAGY \& Bushra Ashour Hajem AL-KHAZRAGY 


\title{
WAYS TO ADDRESS THE WATER CRISES AND ACHIEVE WATER SECURITY (WATER DIPLOMACY AS A MODEL)
}

\author{
Layla Ashour Hajim AL-KHAZRAGY ${ }^{1}$ \\ Bushra Ashour Hajem AL-KHAZRAGY 2
}

\begin{abstract}
:
Water security is one of the most important challenges facing countries that suffer from scarce water resources, as it is an integral part of food security, development and sustainable development. These challenges will not be met without improving the management of water resources in the international rivers shared by states, and from here water diplomacy and negotiation play an important role in alleviating these challenges. As for water diplomacy, it is one of the new and unconventional diplomacy that has recently spread in the practices of relations And with the intensification of controversy over the issues of water distribution among the countries participating in international rivers, including (Egypt and Ethiopia) in the Nile Basin and (Iraq) in the Tigris and Euphrates basins.

Key words: Water Crisis, Water Security, Water Diplomacy, Sustainable Development.
\end{abstract}

http://dx.doi.org/10.47832/ijhercongress2-7

${ }^{1}$ Al-Nahrain University Iraq, laylaalkhazragy@ gmail.com, https://orcid.org/0000-0002-5707-1956

${ }^{2}$ Mustansiriya University Iraq, bushraashur@gmail.com, https://orcid.org/0000-0001-6974-3943 


\author{
سُبل معالجة أزمة المياه وتحقيق الأمن المائي

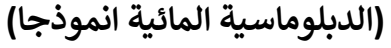 \\ ليلى عاشور حاجم الخزرجي 3 \\ بشرى عاشور حاجم الخزرجي4
}

الملخص:

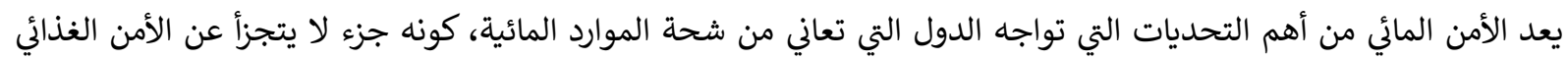

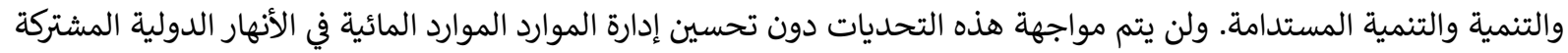

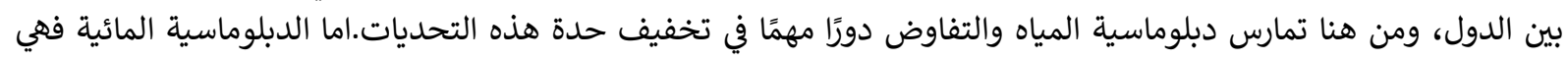

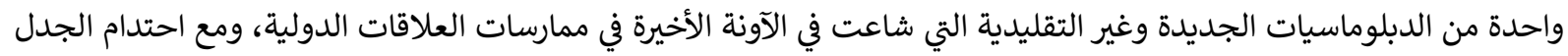

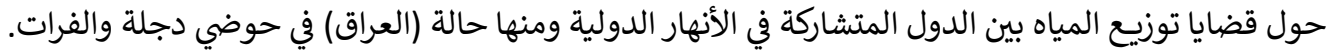
الكلمات المفتاحية:: أزمة المياه، الأمن المائي، الدبلوماسية الأنهار المائية المائ.

المقدمة

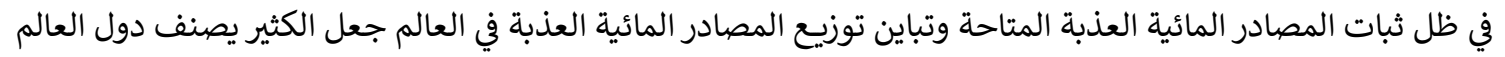

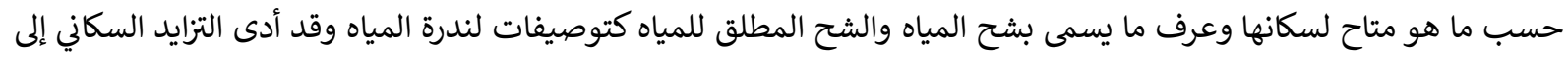

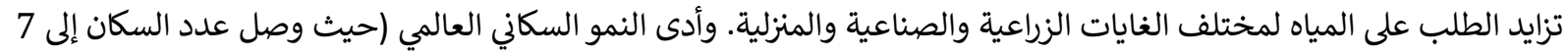

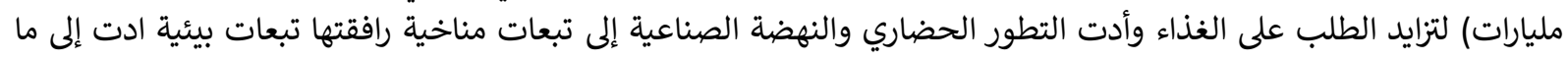

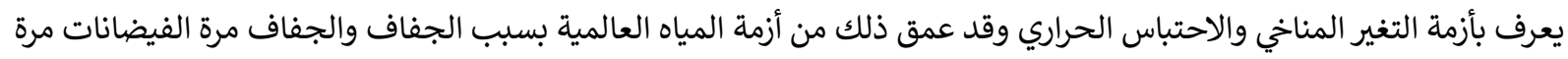

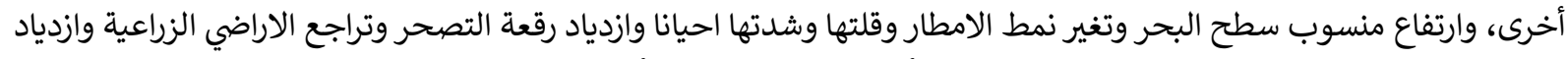

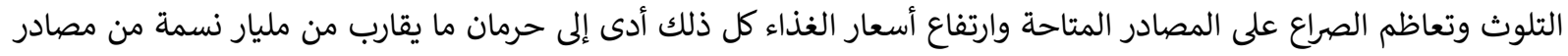

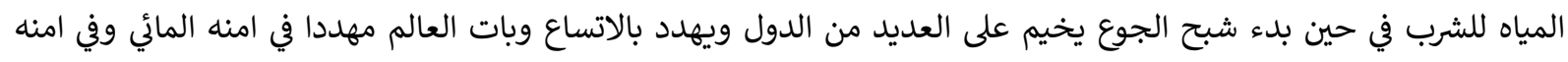
الغذائي في ظل ما يعرف بالازمات العالمية للمياه وللغذاء والطاقة.

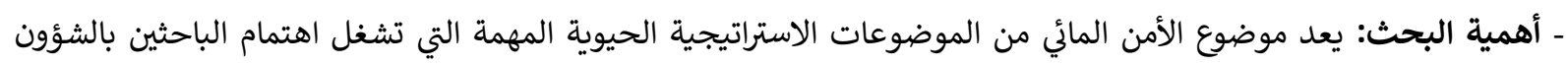

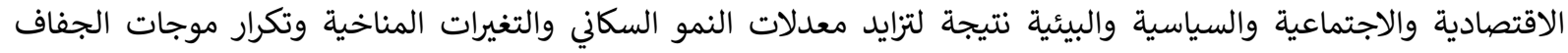
والفيضانات وتفاقم ظاهرة الاحتباس الحرارية والبئية

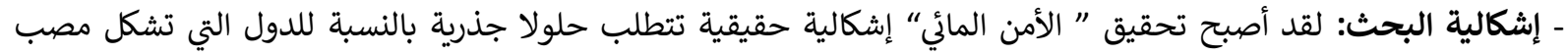

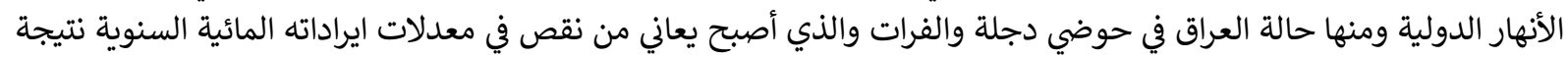

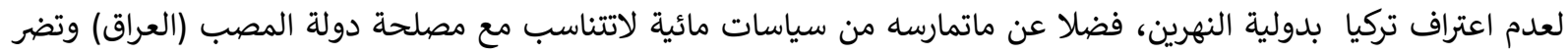

بامنه المائي.

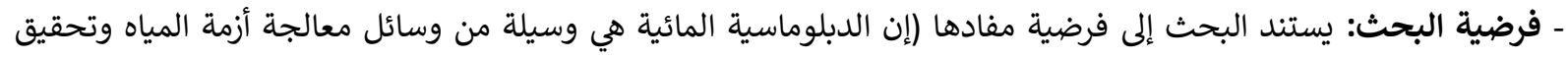

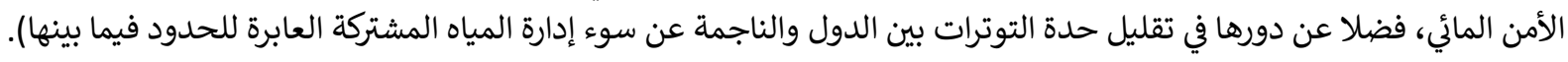

- أهداف البحث: إن للبحث هدفاً علمياً يقوم على البحث في موضوع المياه والأمن المائي في محاولة لتقديم إضافة علمية جديدة

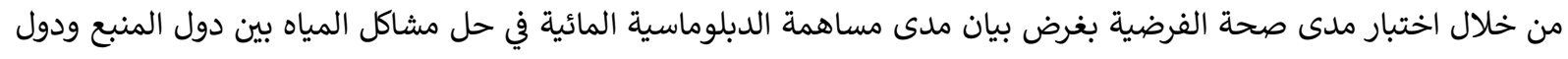

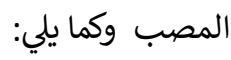
1. تقديم تاصيل مفاهيمي لكل من: الأزمة المائية والأمن المائي والدبلوماسية المائية

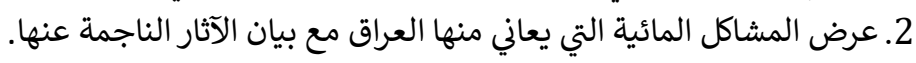

laylaalkhazragy@gmail.com، جامعة النهرين، العراق، إقاق، bushraashur@gmail.com الجامعة المستنصرية، ، العراق، العرين، 


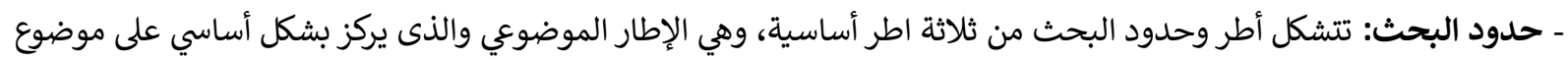

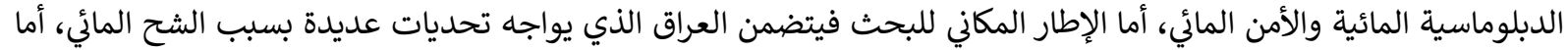
الإطار الزماني للبحث فهو بعد العام 2003

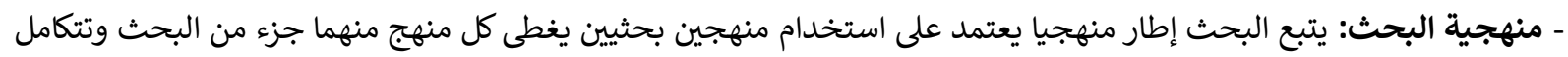

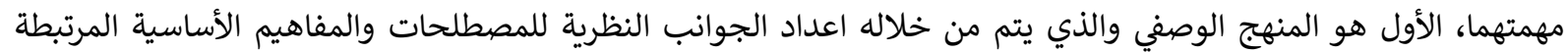

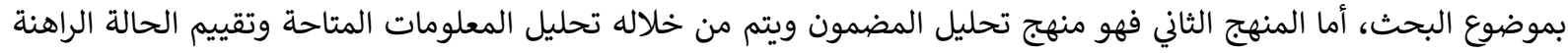

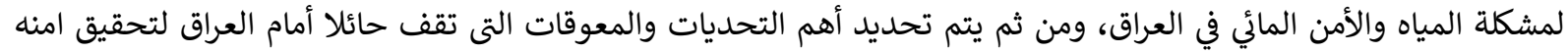
المائي من خلال الدبلوماسية المائية.

- هيكلية البحث: تضمن البحث ثلاث محاور أساسية هي: - (المحور الأول: مدخل مفاهيمي

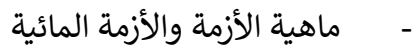

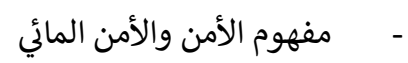
- - مفهوم الدبلوماسية والدبلوماسية المائية

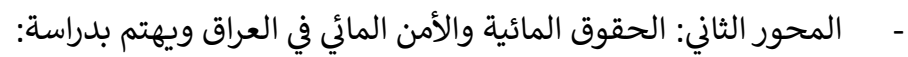
- - - الحقوق المائية للعراق ضمن حوضي نهري دجلة والفرات. -

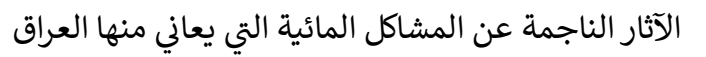

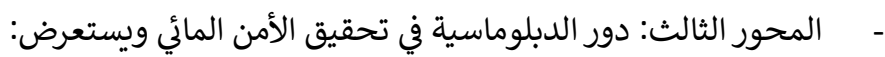

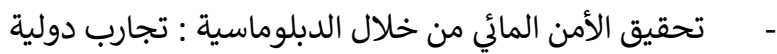

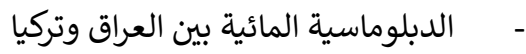
آليات الدبلوماسية المائية في حل المشاكل المائية العراقية مع تركيا

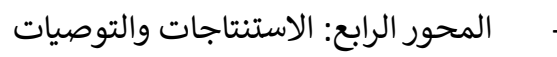
- - - 
المحور الأول: مدخل مفاهيمي

يشكل توضيح المفاهيم والمصطلحات مفتتح المنهجية العلمية، لا سيّما وأن البحث يضم فئ في ثناياه

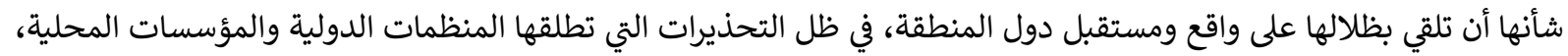

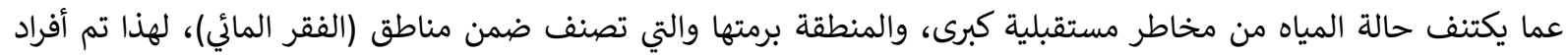

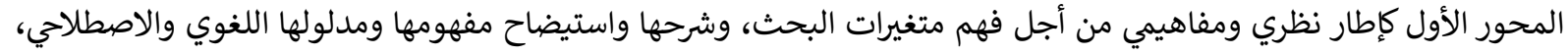
وكذلك العمل على تقديم توضيح وتفسير ترابط هذه المتغيرات من جهة، وإبراز أهم ما تطرحه هذه المقاريات المغاريات النظرية من جهات

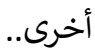

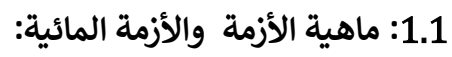

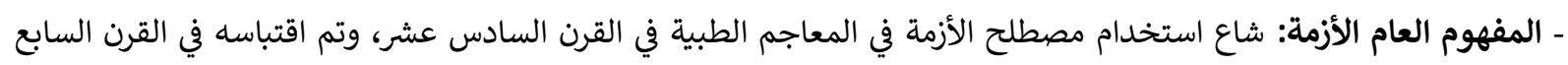

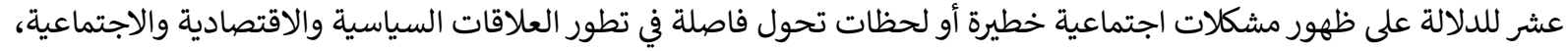

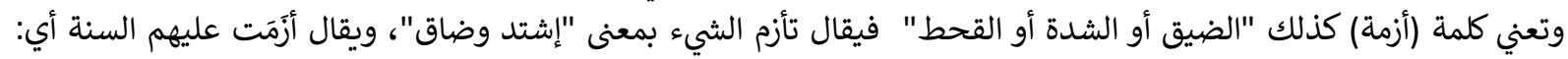

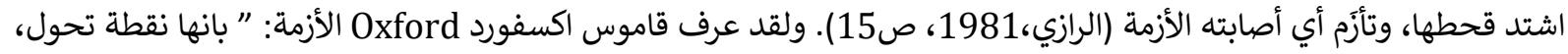

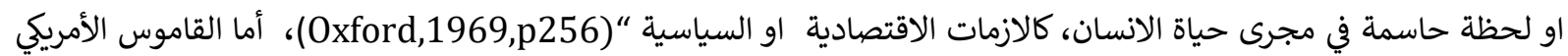
(Dictionary of American )

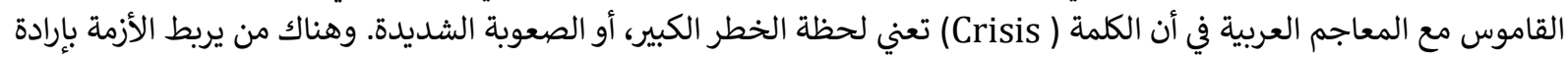

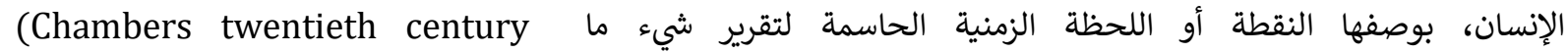

.(dictionary,1974,p275

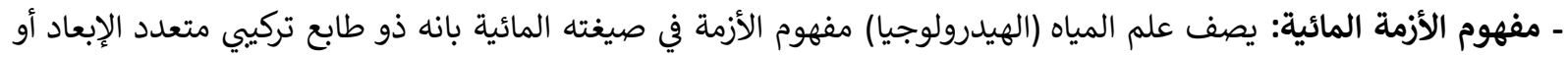

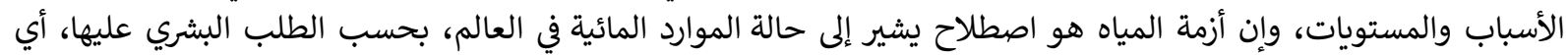

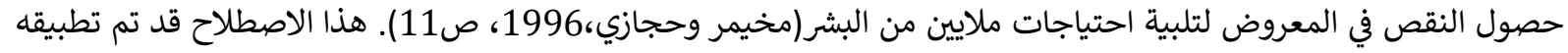

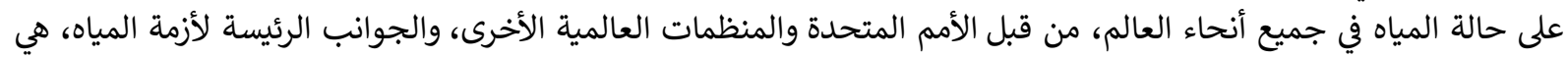

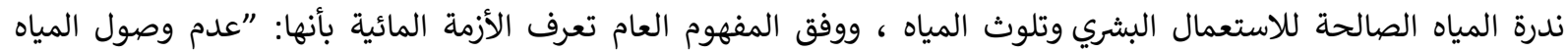

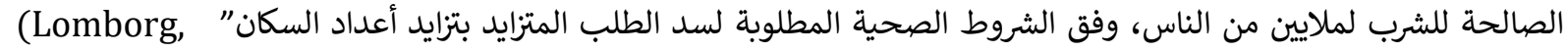

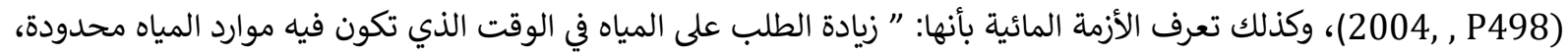

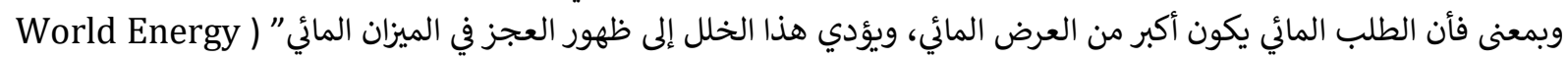

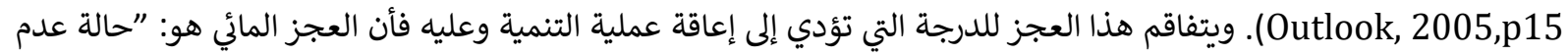

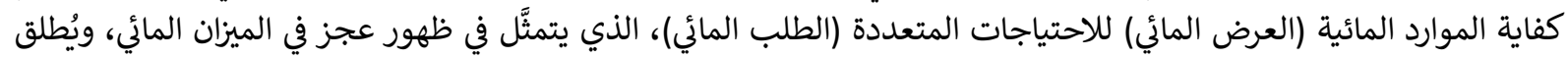

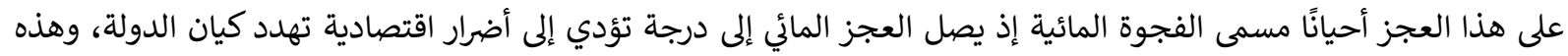

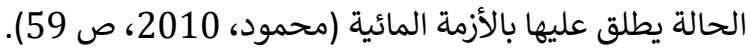

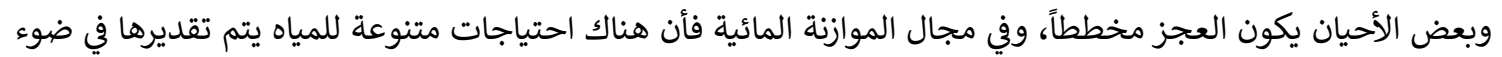

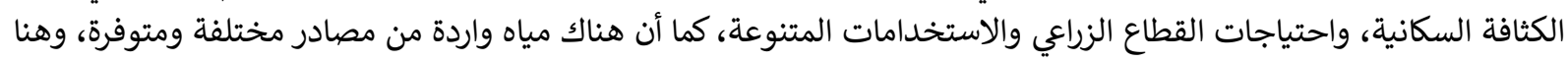

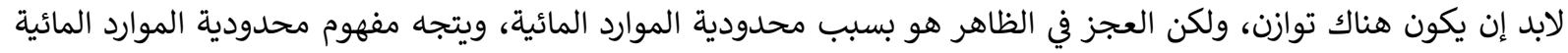

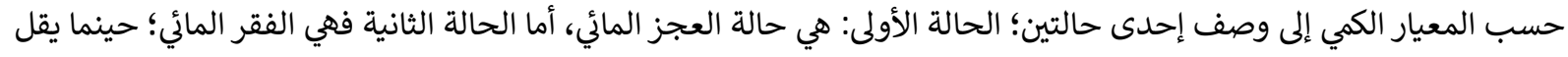

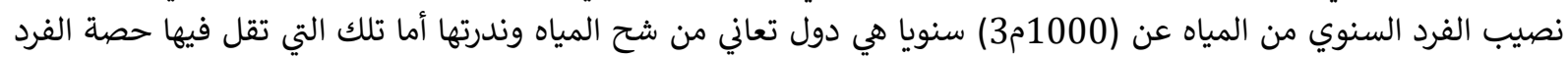

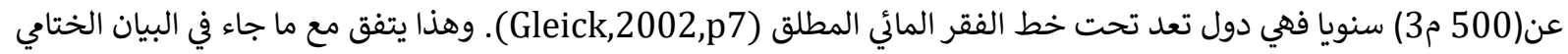

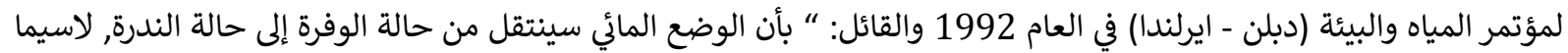

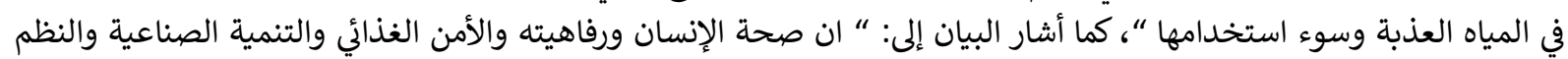

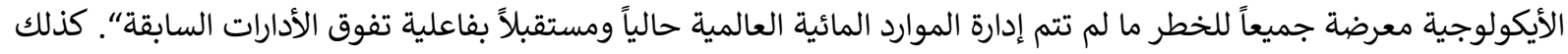

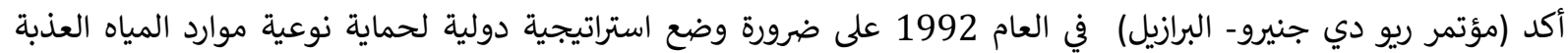

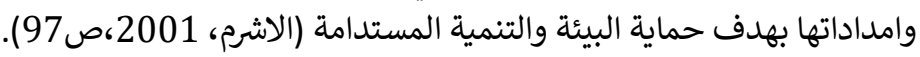




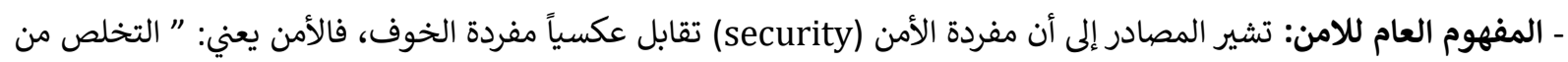

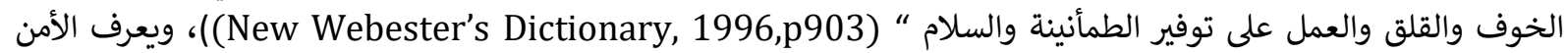
كذلك بأنه: " التحرر من الهم والقلق والتخلص من الخطر وتحقيق الثقة والطمأنينة وتوفير السلامة والإستقرار" (Chambers)

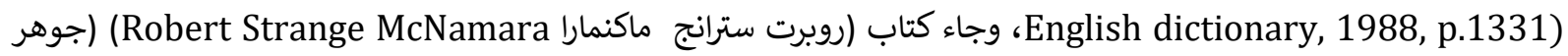

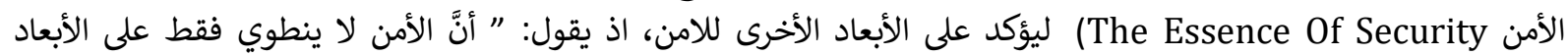

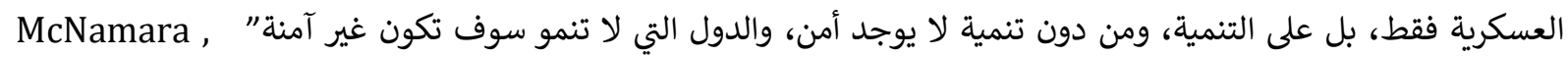

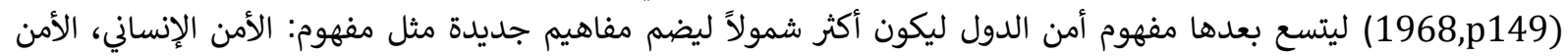
البيئي، الأمن الغذائي، الأمن السياسي، الأمن الاقتصادي، وتعد مسألة الأمن المائي على رأس تلك المغاهئ المفاهيم.

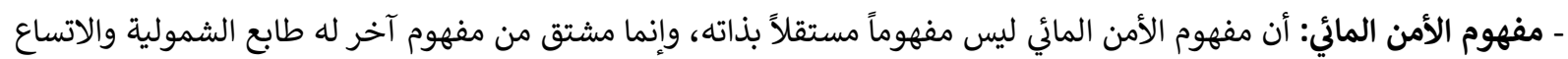

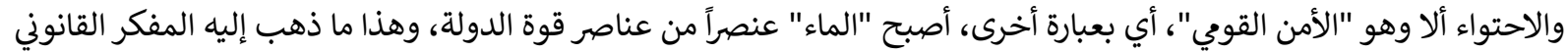

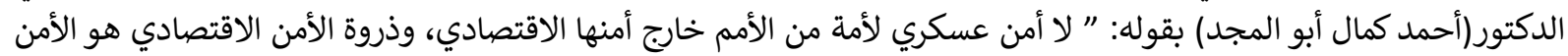

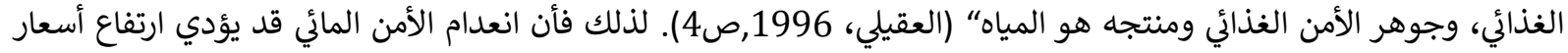

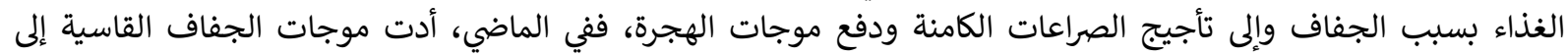

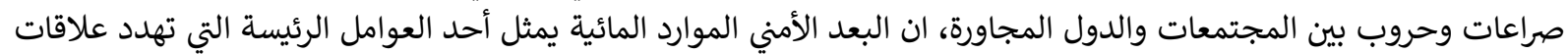

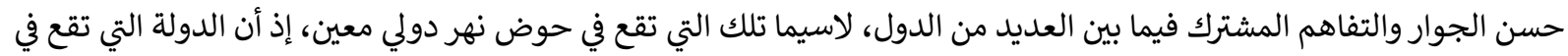

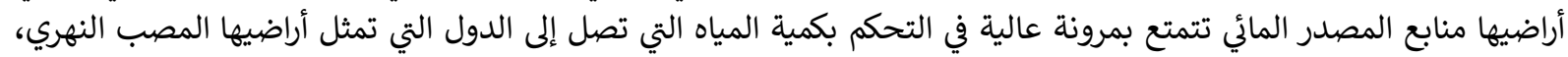

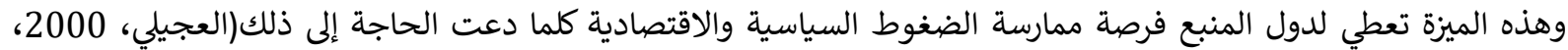

وفي مطلع عقد التسعينيات من القرن العشرين، ورد في تقرير التنمية البشرية الصادر عن الأمم المتحدة لعام 1990 فئرئ فكرة

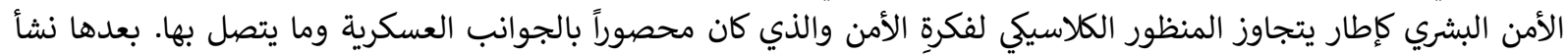

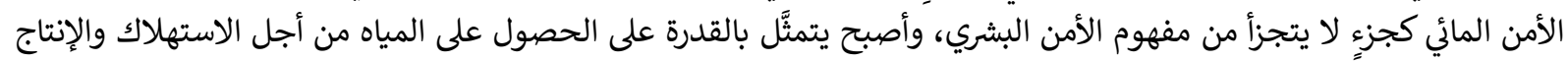

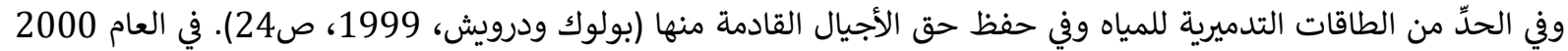

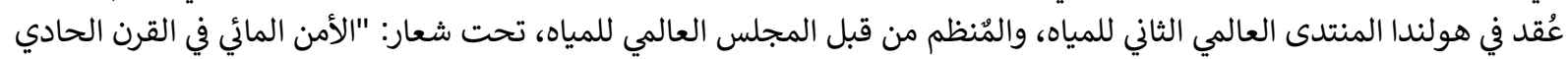

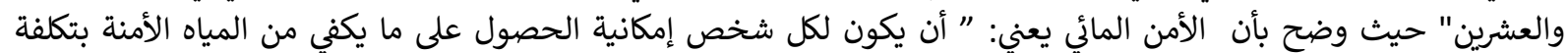

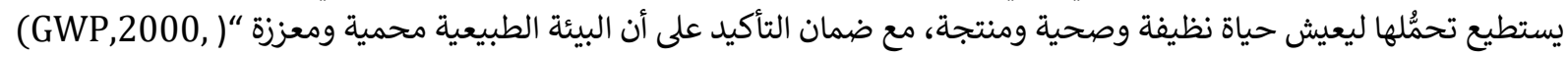

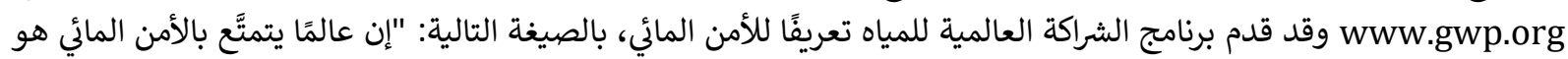

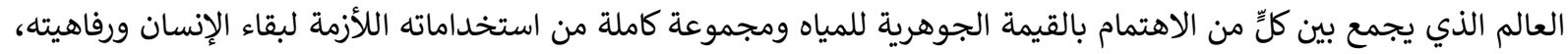

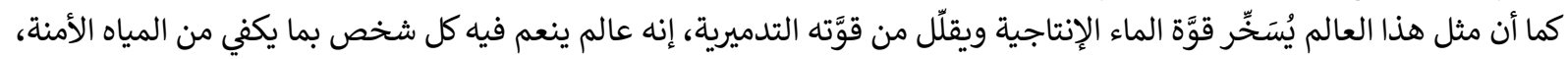

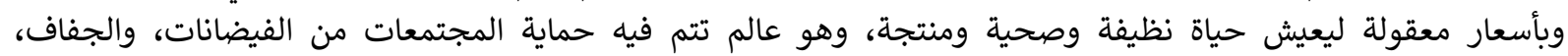
والانهيارات الأرضية، وانجراف التربة، والأمراض التي تنقلها المياه" (GWP , 2012, www.gwp.org).

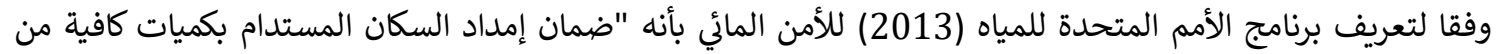

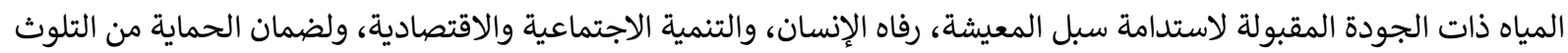

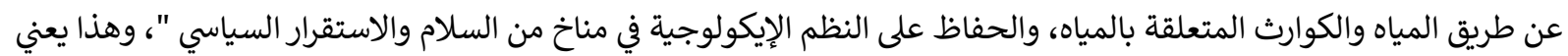

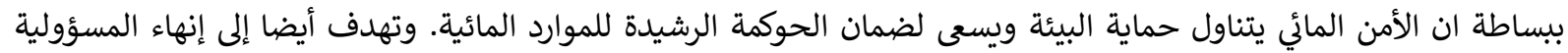

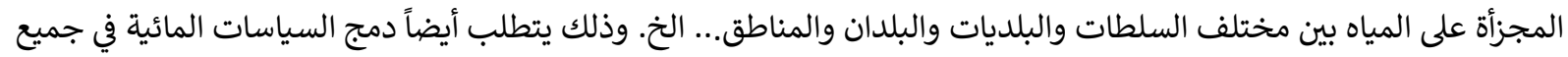

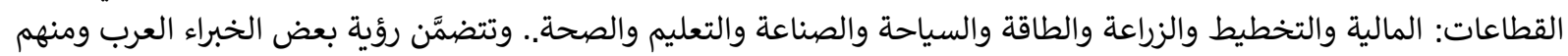

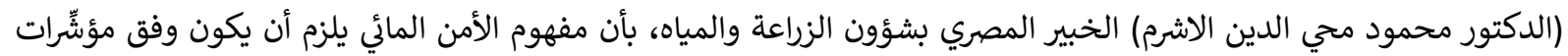

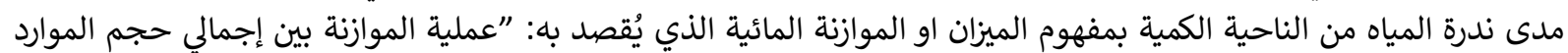

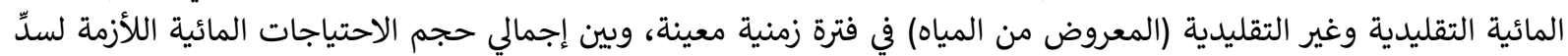

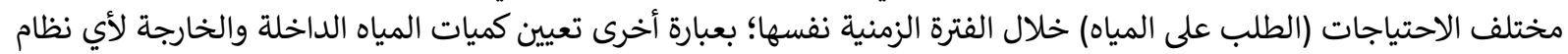
مائي" (الاشرم، 2001، صنات (30). 


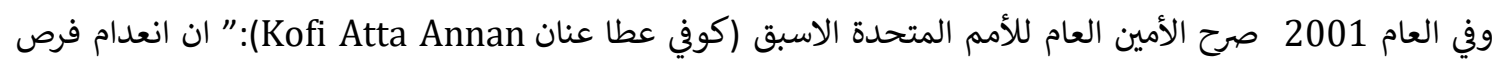

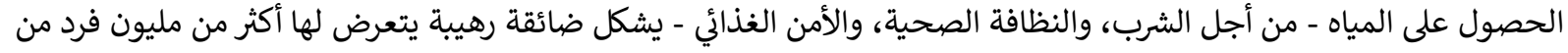

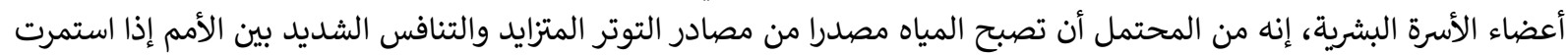

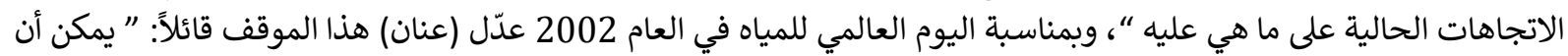

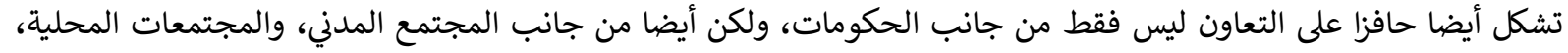

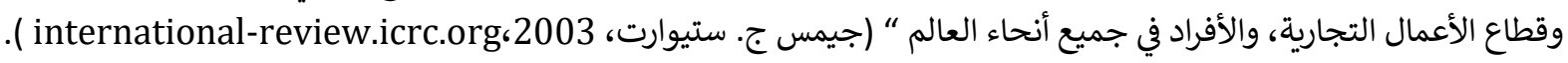

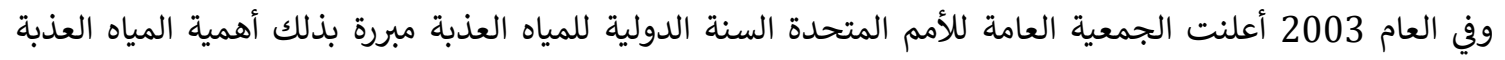

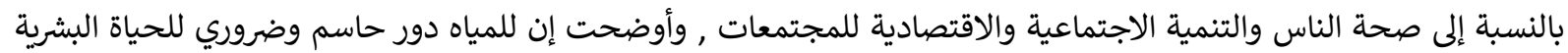

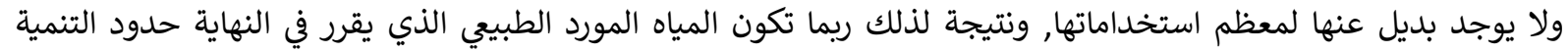

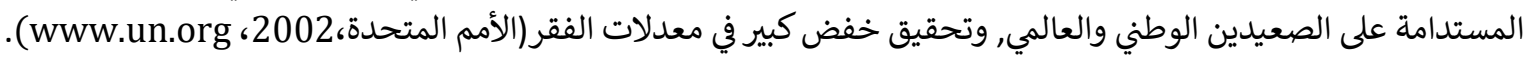

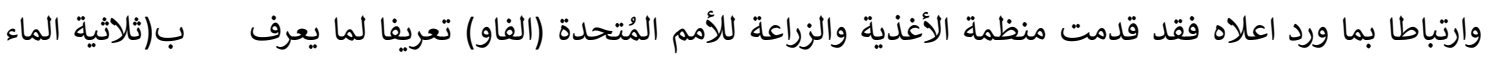

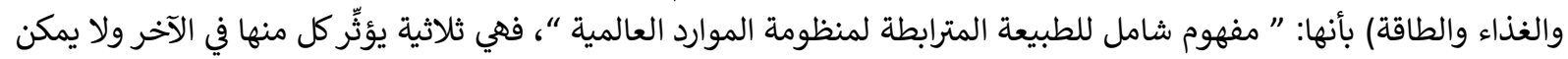

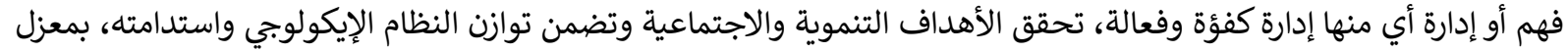

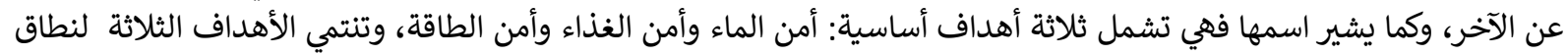

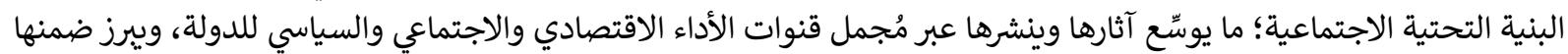

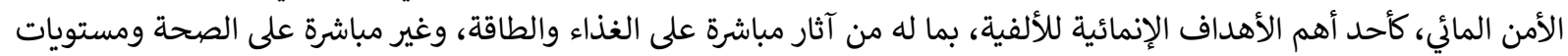

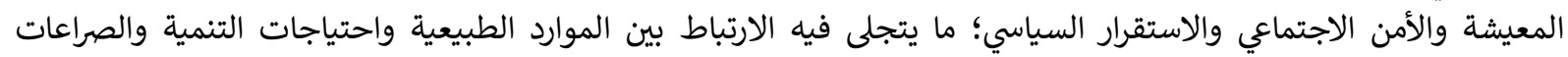

الإقليمية والدولية (Food and Agriculture Organization,2014,p3).

3.1 - مفهوم الدبلوماسية والدبلوماسية المائية:

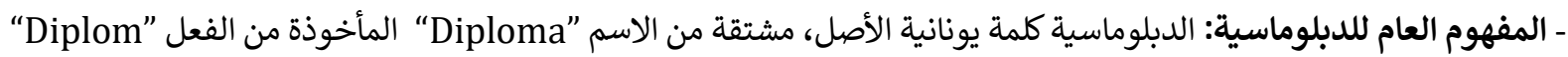

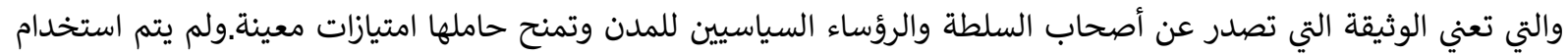

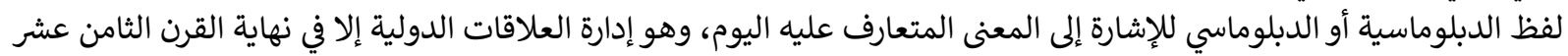

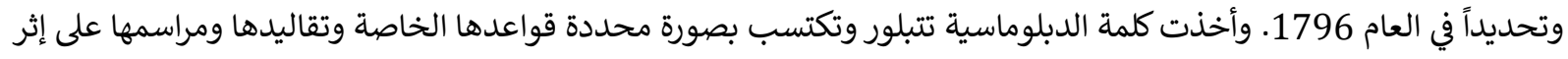

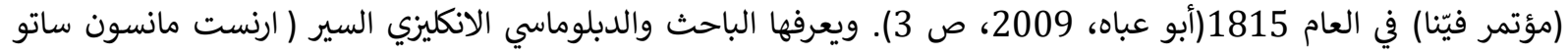

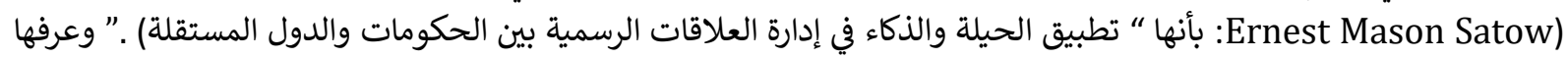

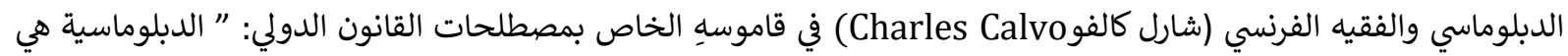

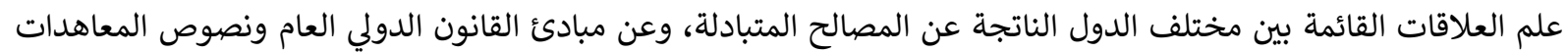

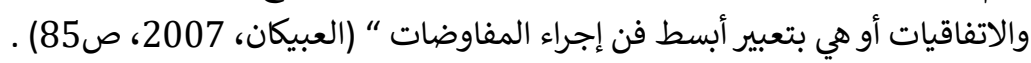

- مفهوم الدبلوماسية المائية: ومن اجل الحصول على فهم أفضل للدبلوماسية المائية يجب التهاءئ التمييز بين دبلوماسية المياه والمفاهيم الأخرى ذات الصلة ومنها:

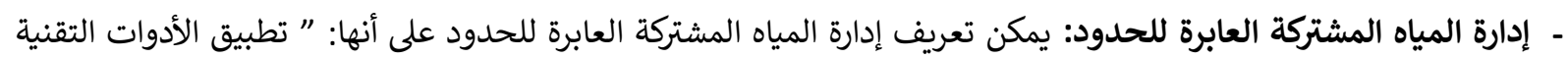

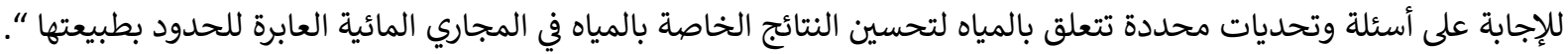

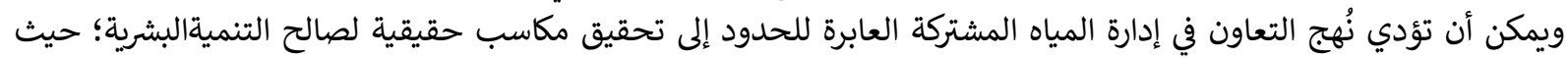

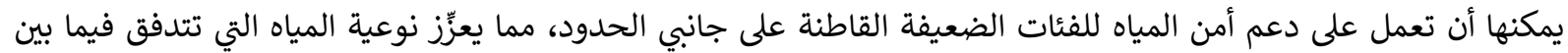

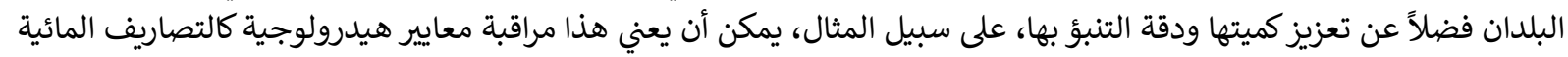

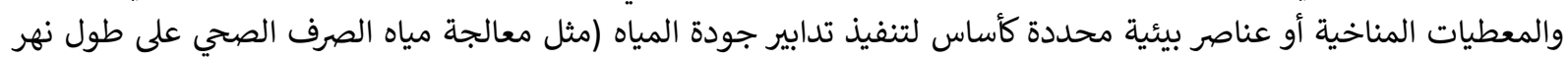

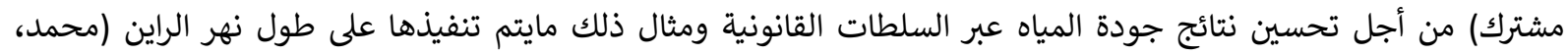

.(www.ssrcaw.org ،2020

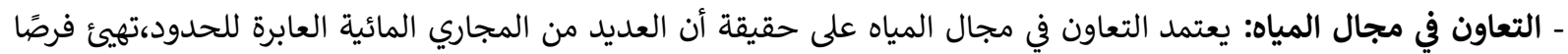

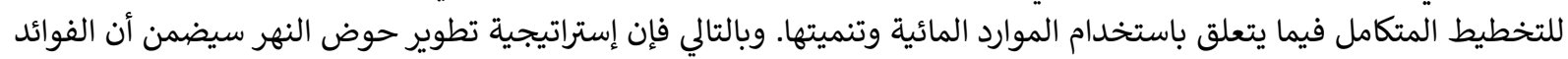

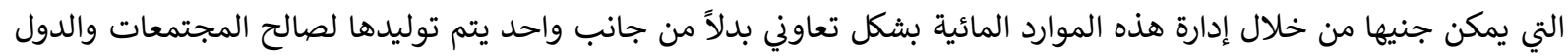

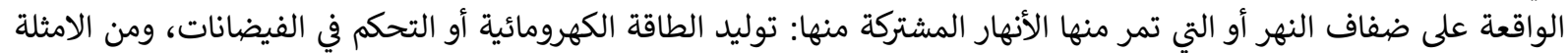

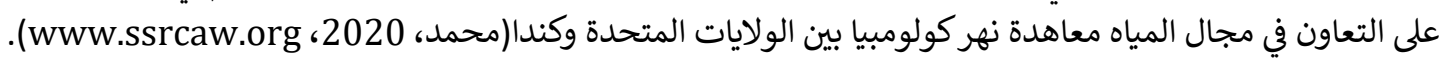


تمثل الدبلوماسية المائية أحد أنماط الدبلوماسية الحديثة التي تعتمد على نهج ممارسة الدبلوماسية بشكل أكثر تكثيفا

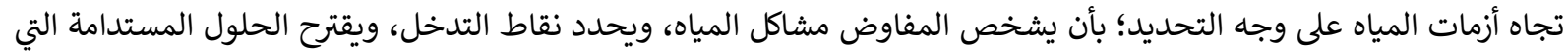

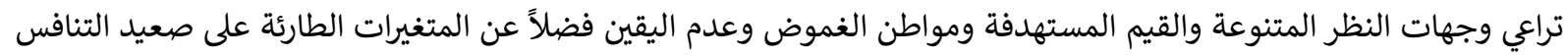

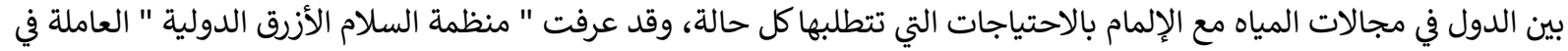

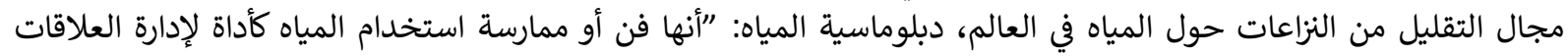

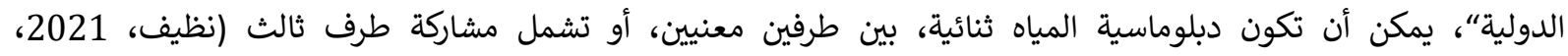
www.annaharar.com

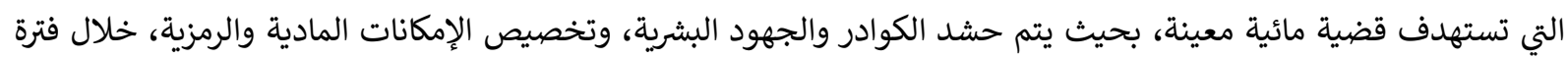

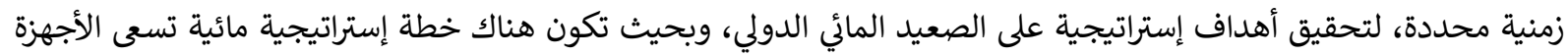

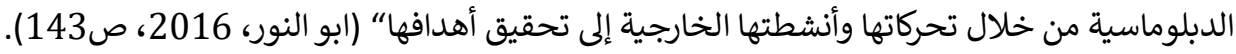
ويرى العالم (شفيق اسلام Shafiq Ulislam) أستاذ الهندسة وأستاذ دبلوماسية المياه في كلية فليتشر للقانون

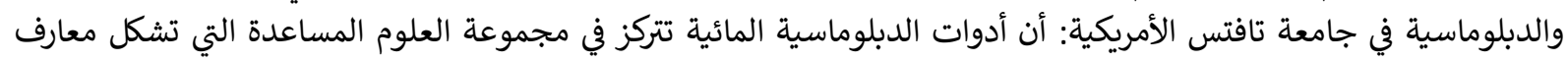

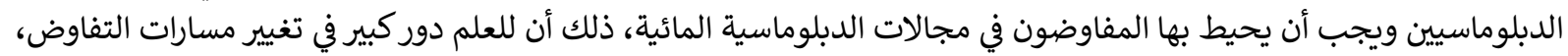

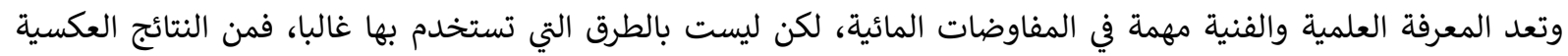

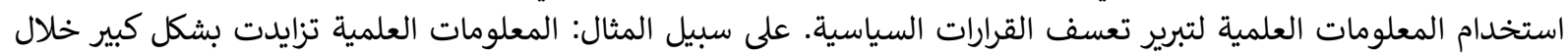

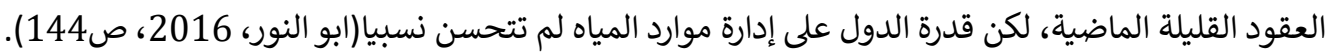

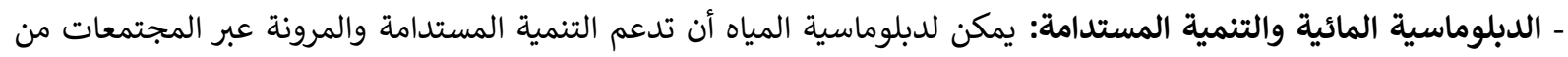

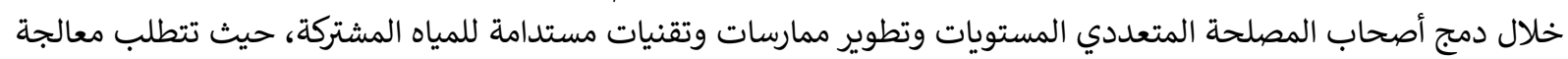

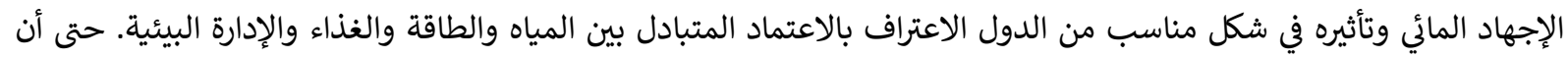

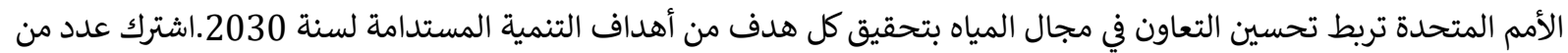

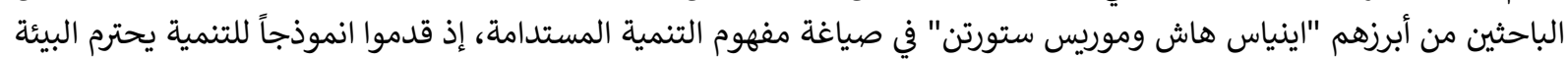

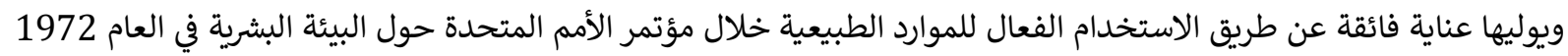

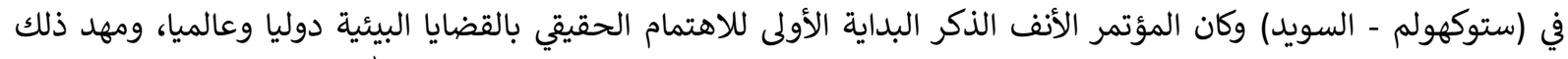

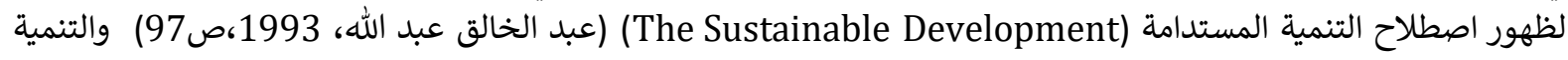

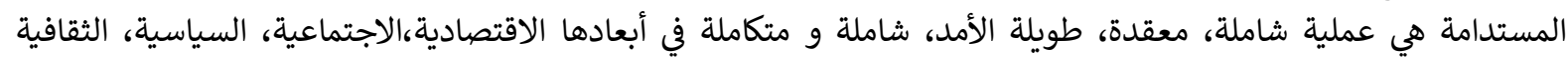

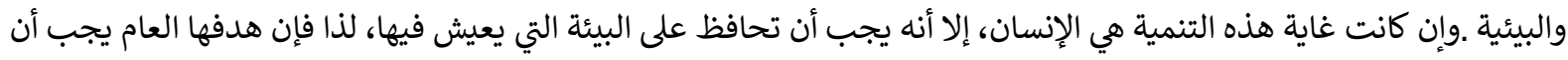

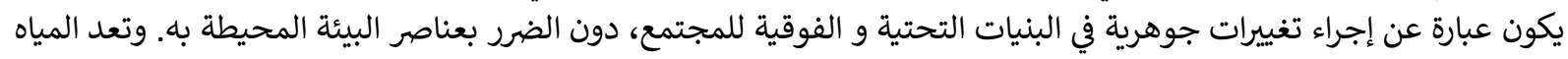

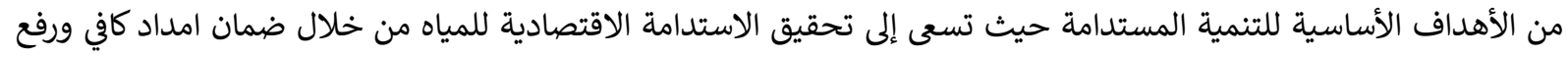

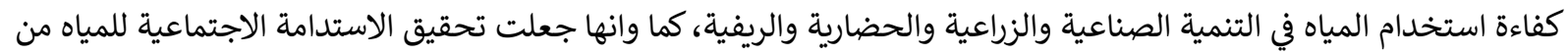

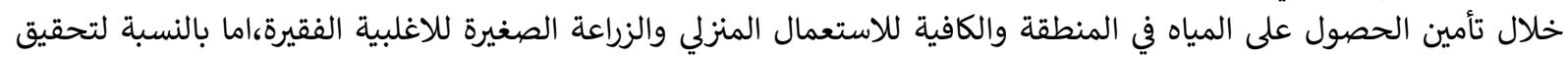

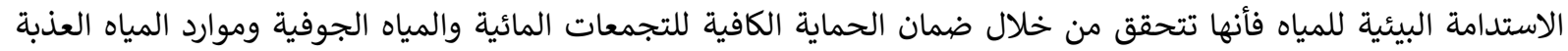

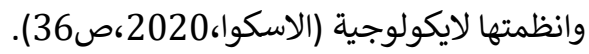


المحور الثاني

الحقوق المائية والأمن المائي في العراق

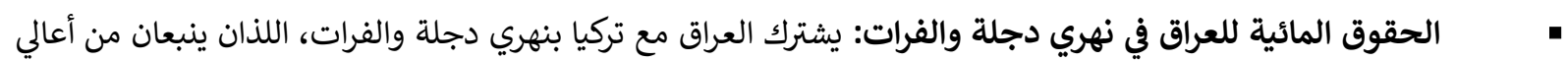

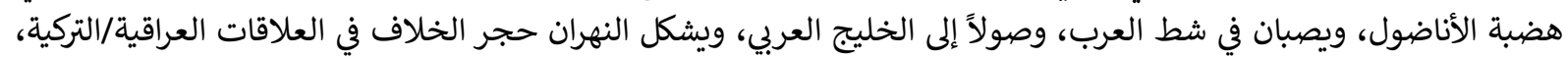

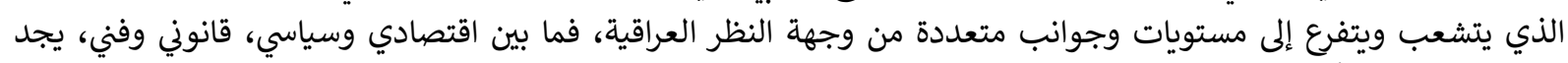

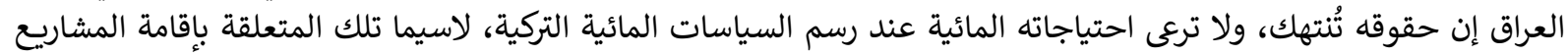

على دجلة والفرات.

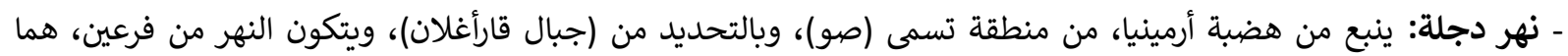

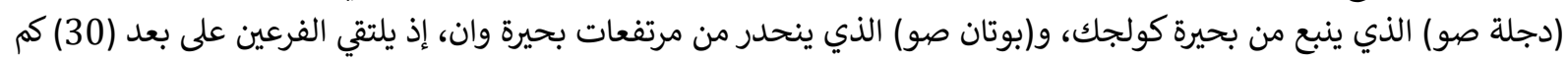

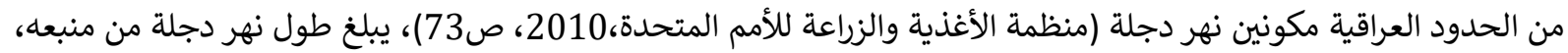

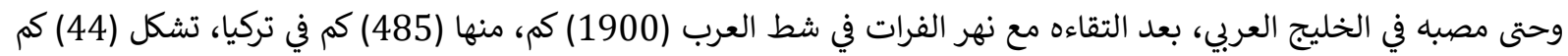

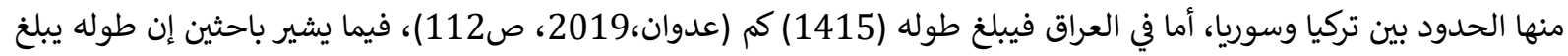

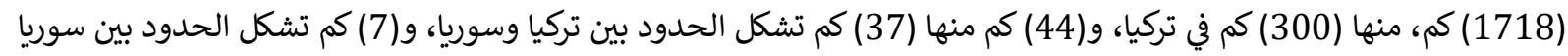

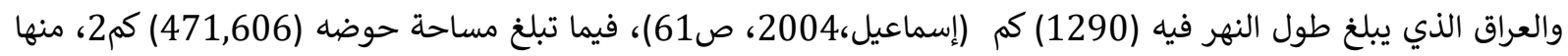

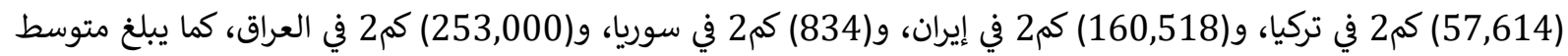

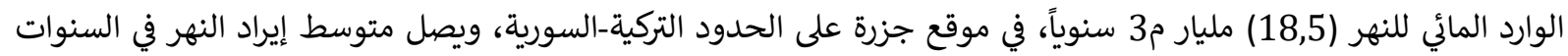

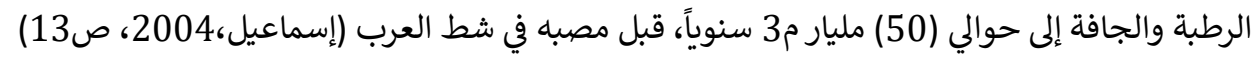

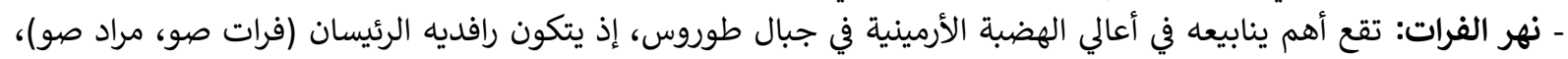

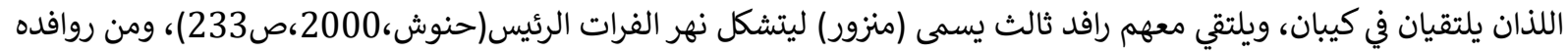

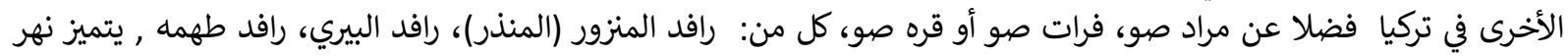

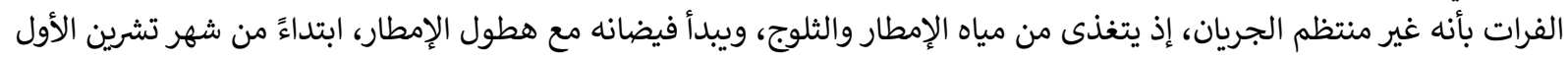

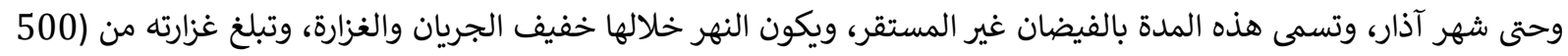

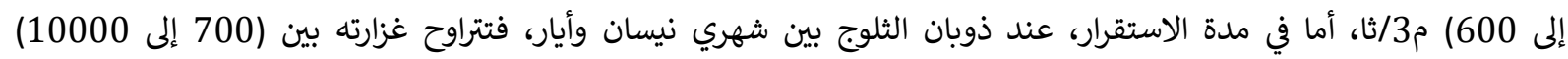

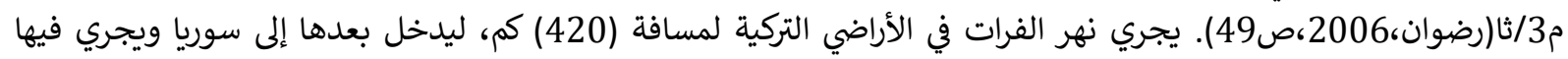

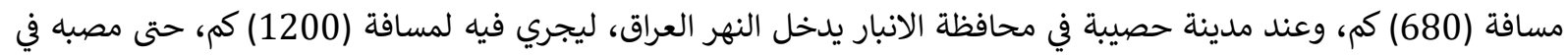

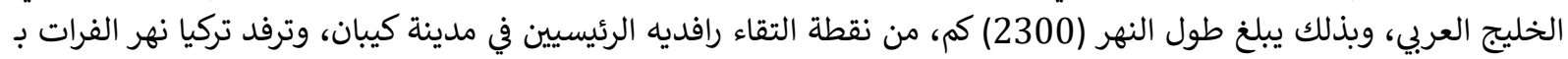

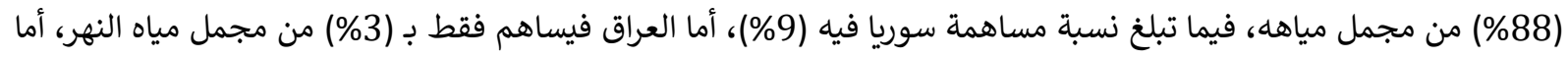

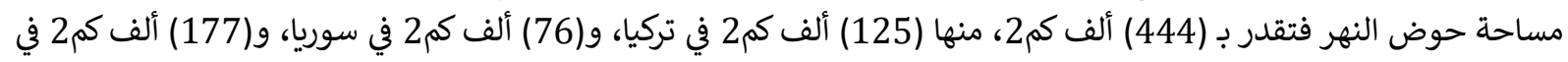

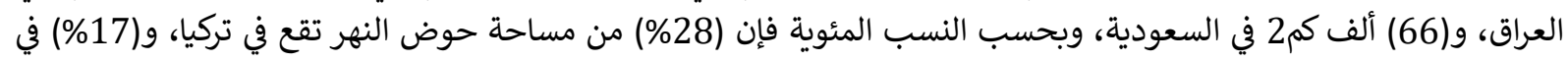

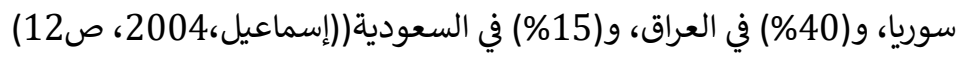

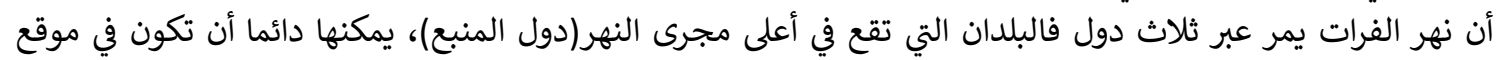

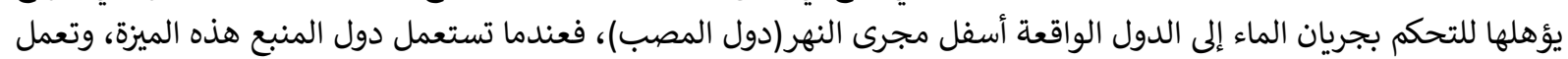

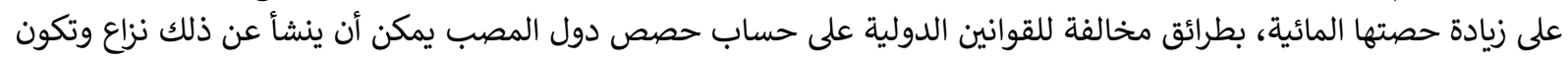

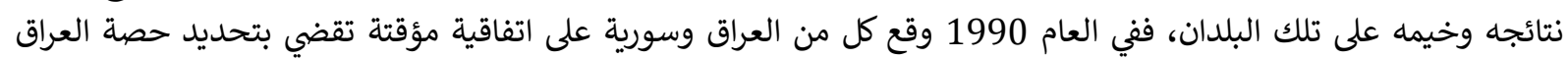

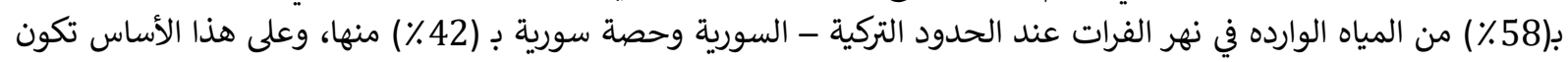

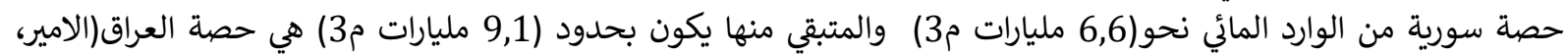

.1420، 2010، (14)

• المشاكل المائية بين العراق وتركيا: منذُ تأسيس تركيا الحديثة في العام 1923، وكتئ وحتى الآن اتسمت العلاقات العراقية التركية

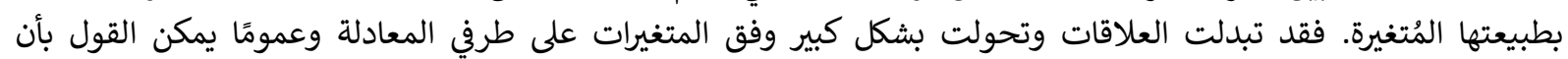

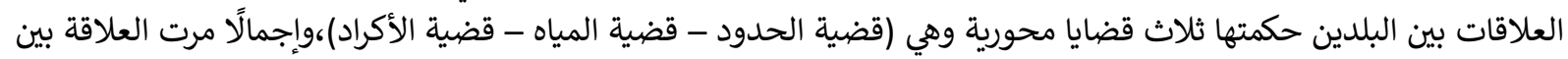

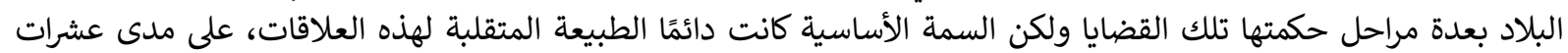

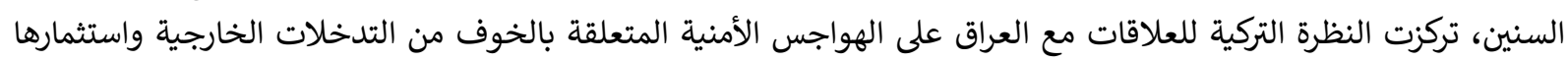

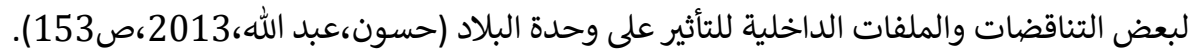




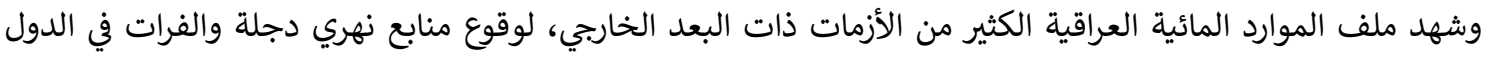

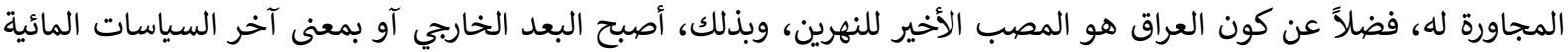

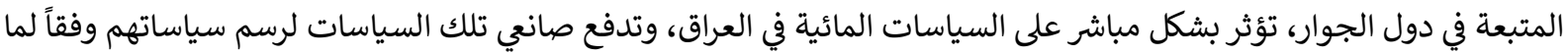

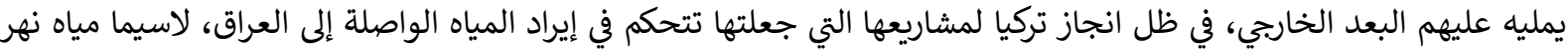
الفرات.

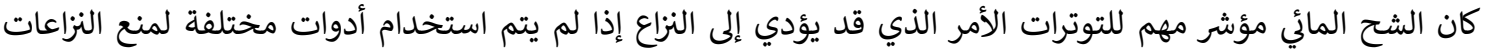

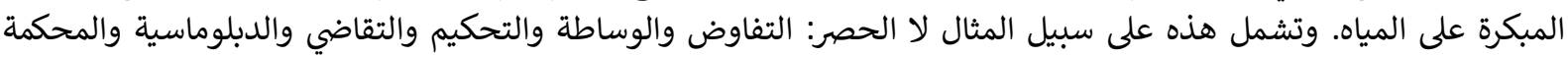

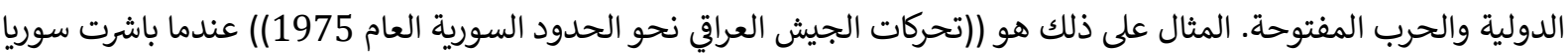

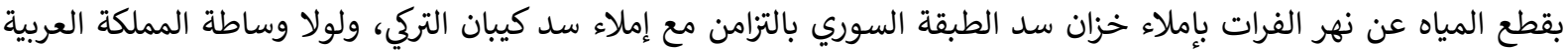

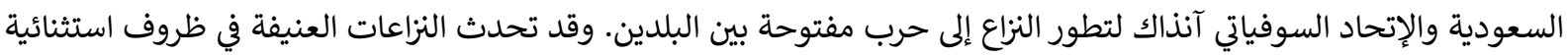

فقط (محمد،2020، www.ssrcaw.org ).

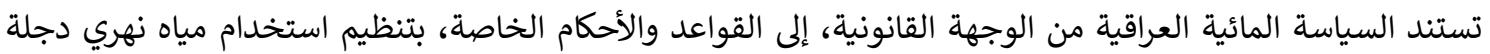

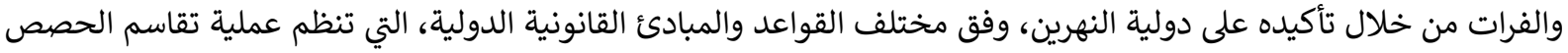

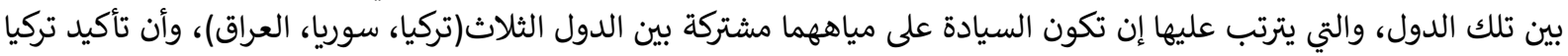

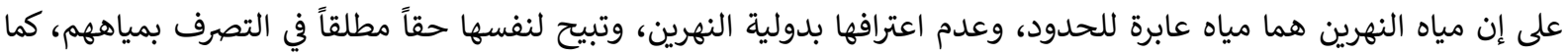

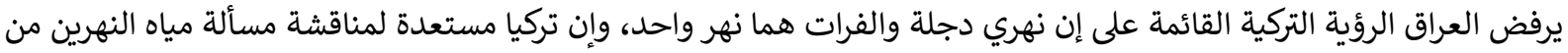

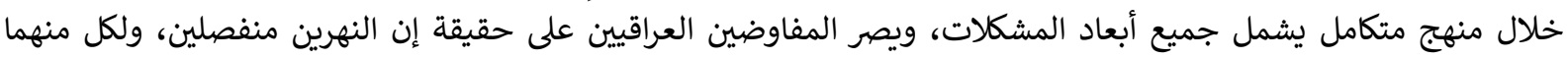

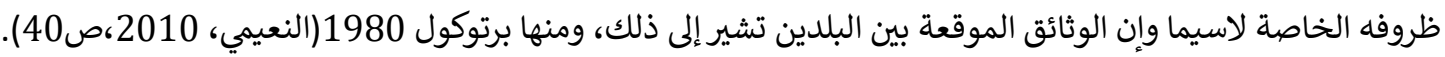

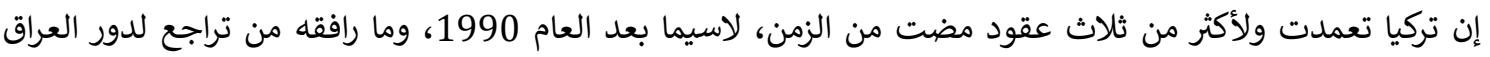

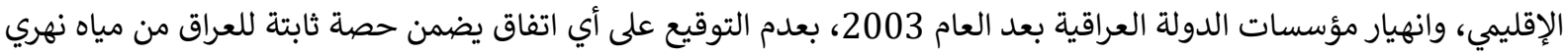

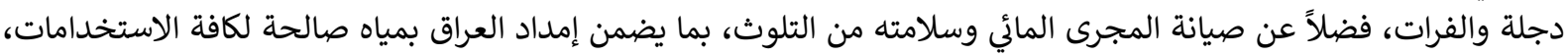

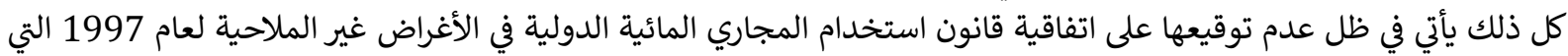

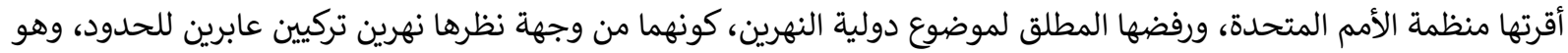

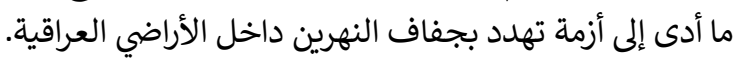
• الآثار الناجمة عن المشاكل المائية تهددية التي يعاني منها العراق: الهم الآثار الناجمة عن عن المشاكل التاكل المائية في العراق نتيجة

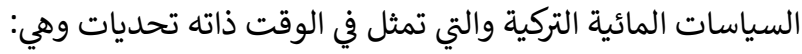

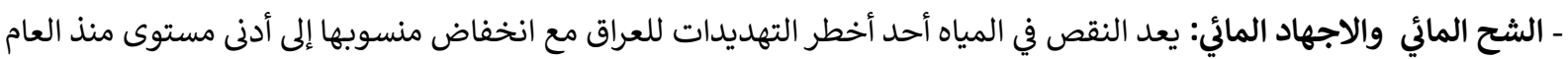

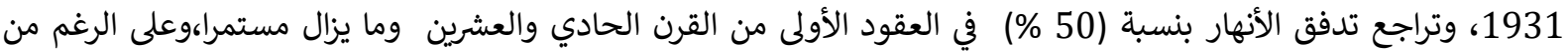

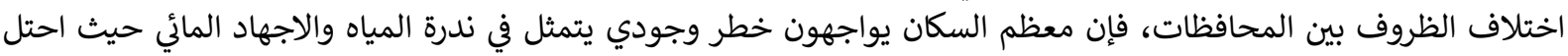

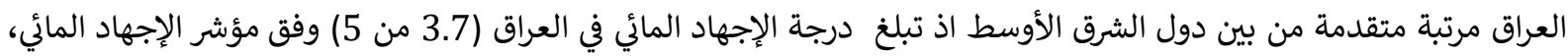

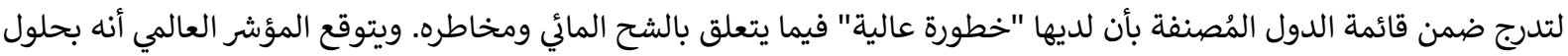

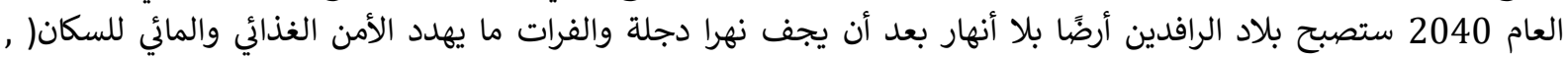

(2018,www.wri.orgTianyi Luo

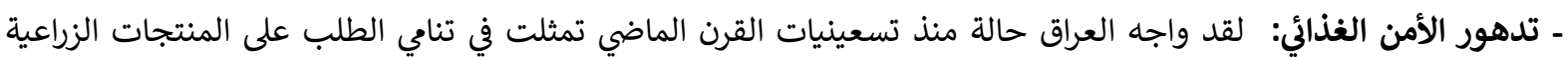

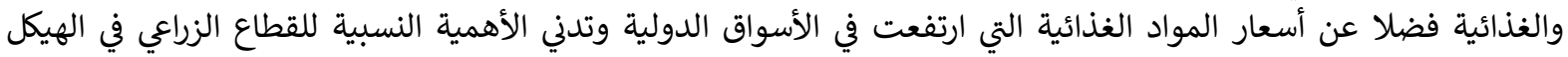

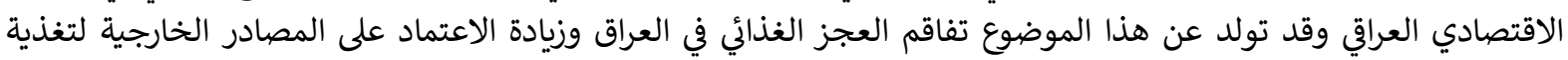

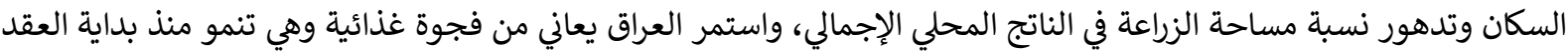

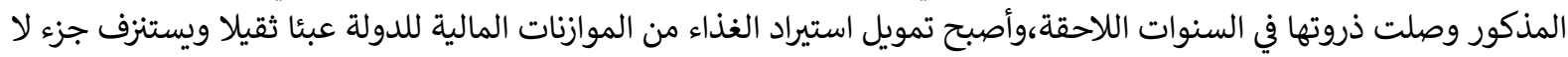

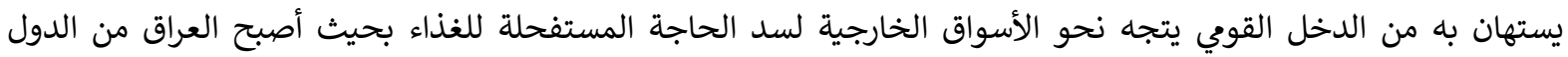

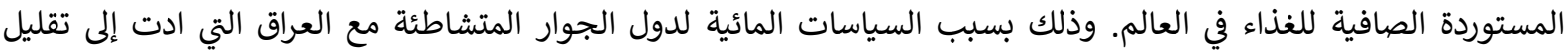

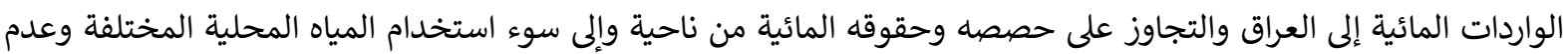

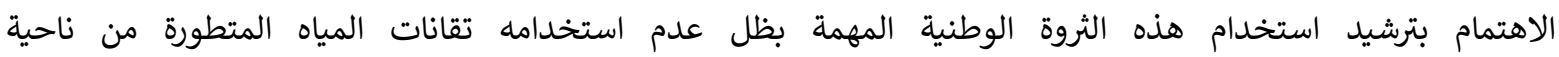

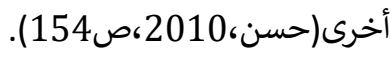




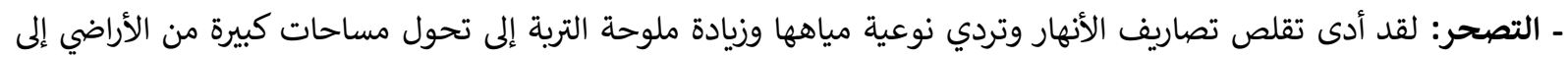

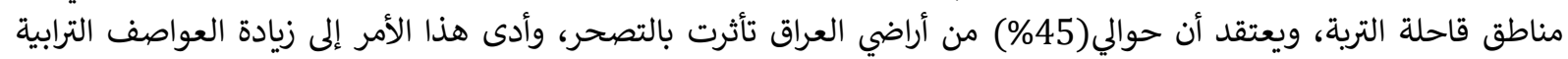

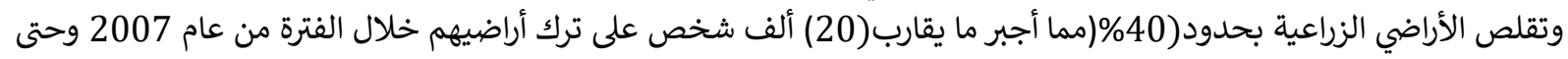

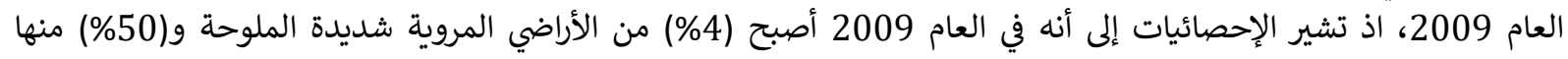

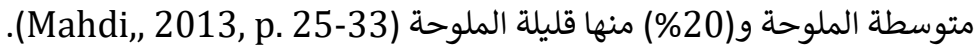

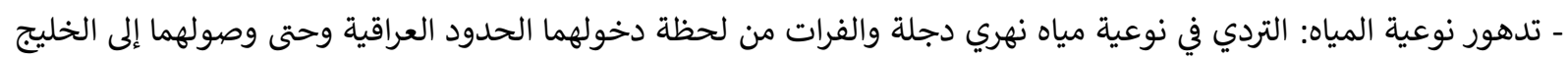

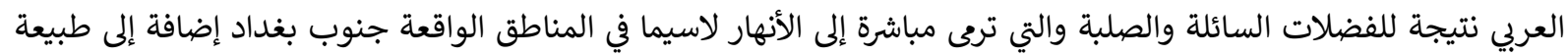

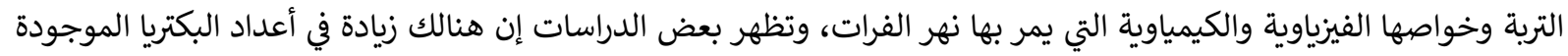

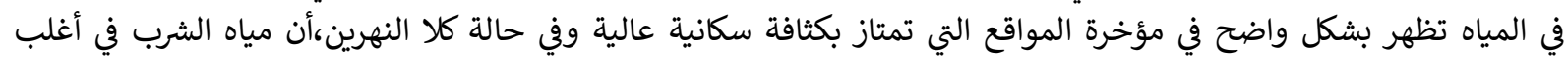

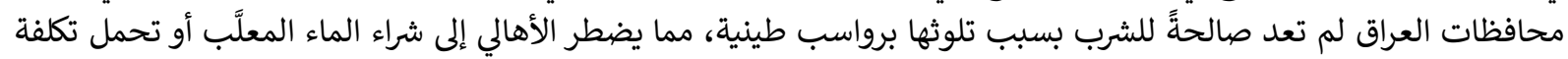
المرض نتيجة شرب المياه الملوَّثة.

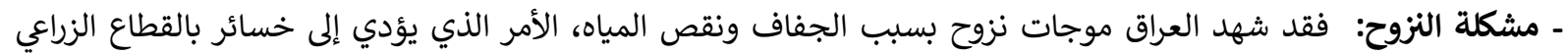

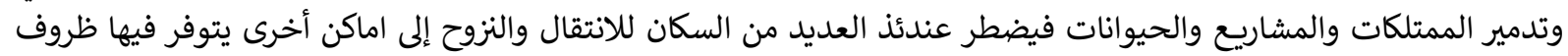

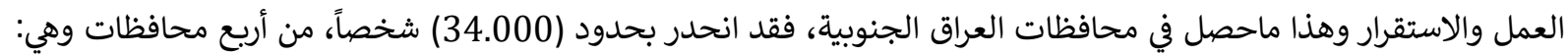

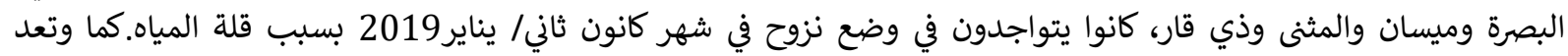

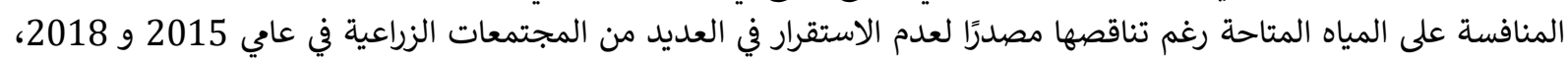

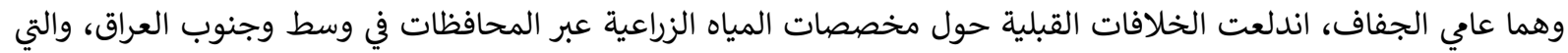

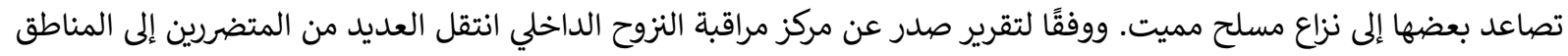

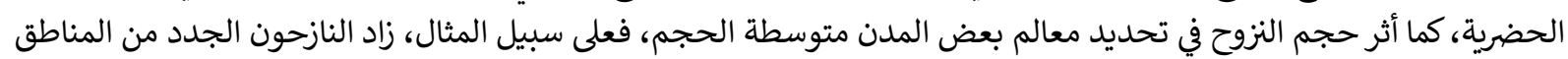

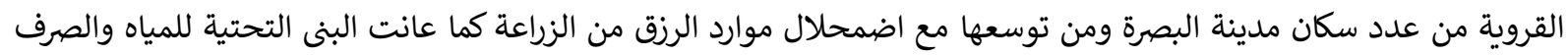

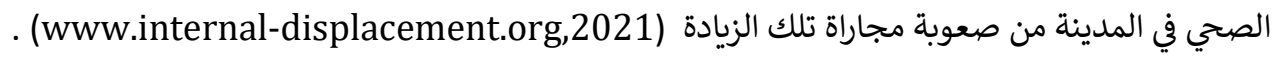




\section{التعاون المائي دور الدبلوماسية في تحقيق الأمن المائي}

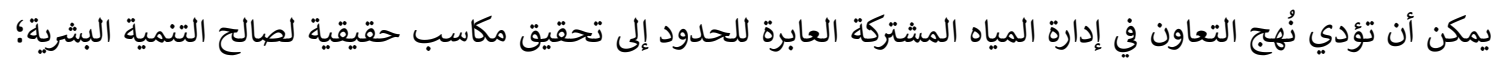

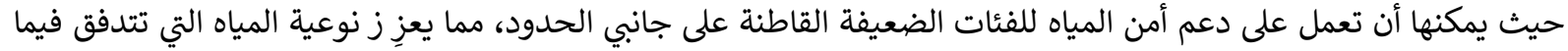

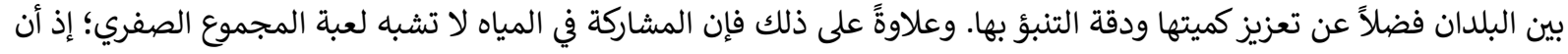

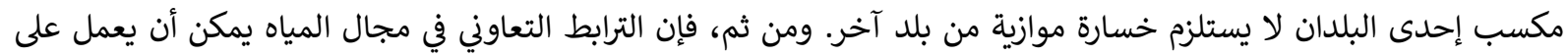

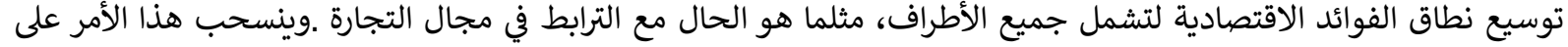

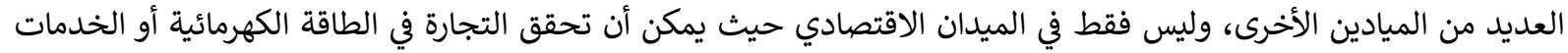

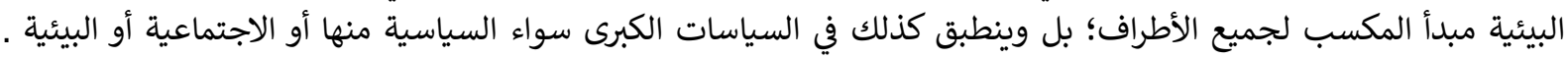

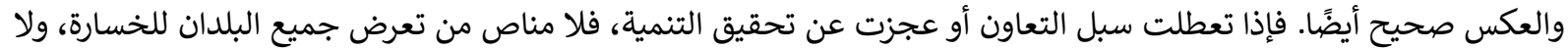

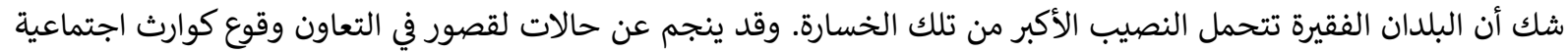

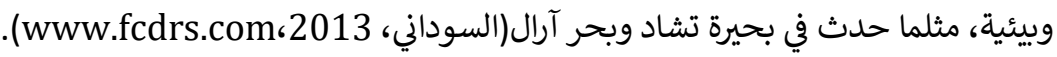

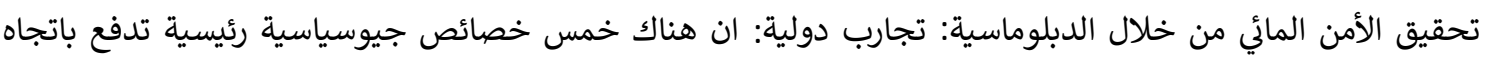

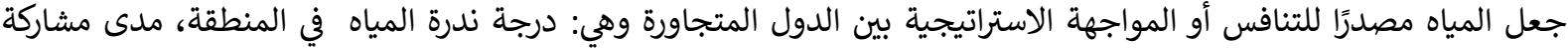

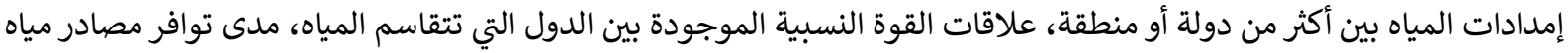

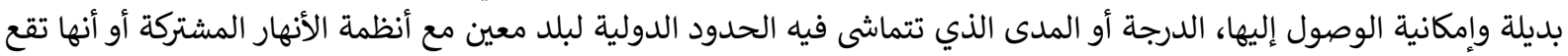

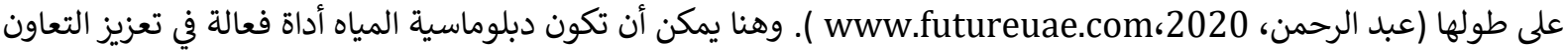

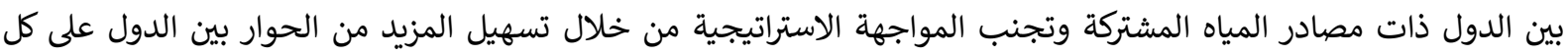

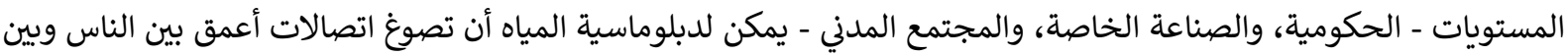
الخبراء. فضلا عن ذلك، يمكن لاتفاقات دبلوماسية المياه أن تكون بمثابة أطر للتفاوض يمكاء

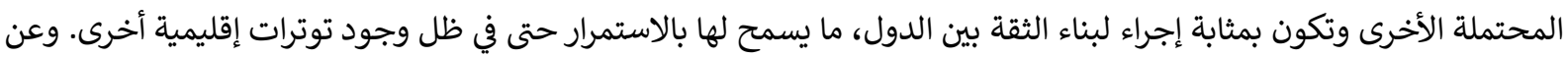

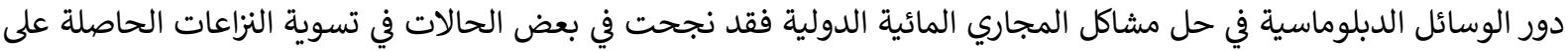

بعض أنواع المجاري المائية الدولية منها:

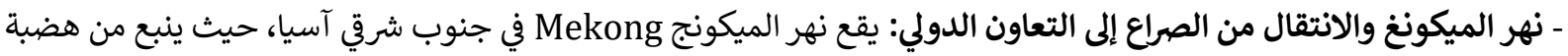

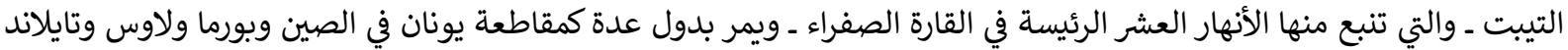

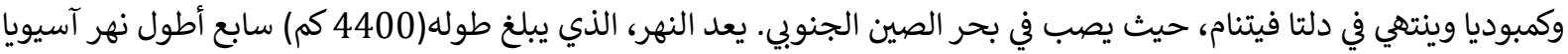

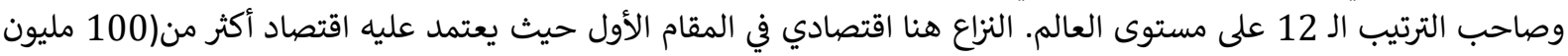

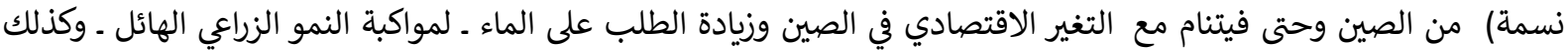

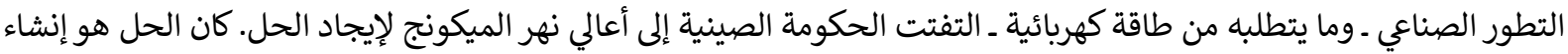

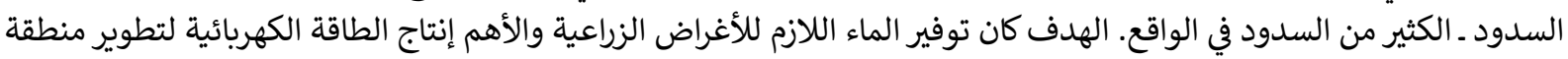
جنوب شرق الصين.

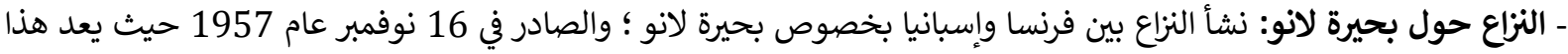

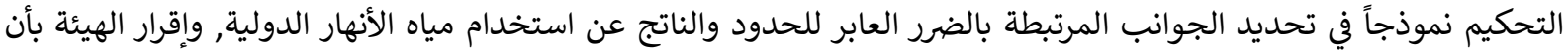

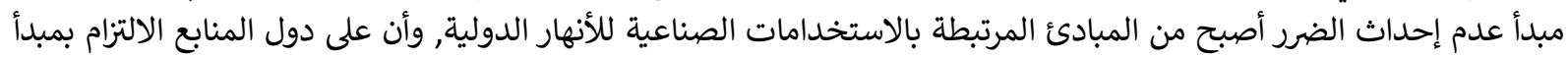

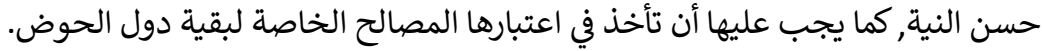

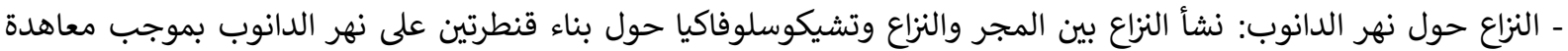

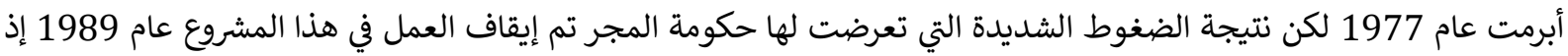

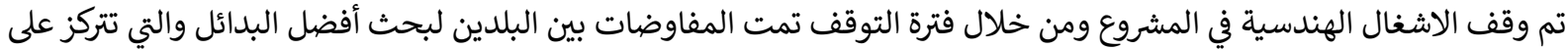

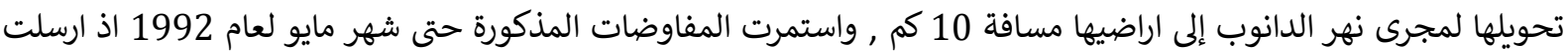

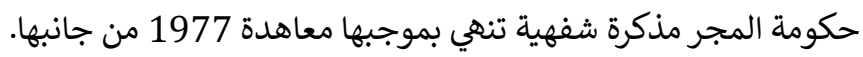

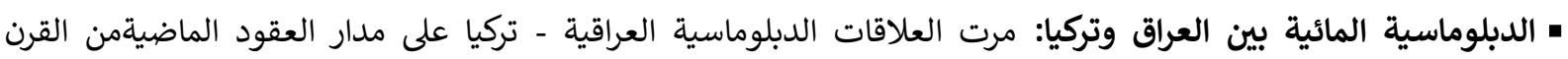

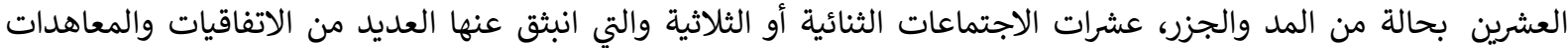

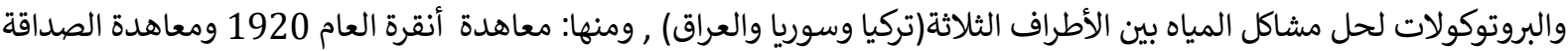

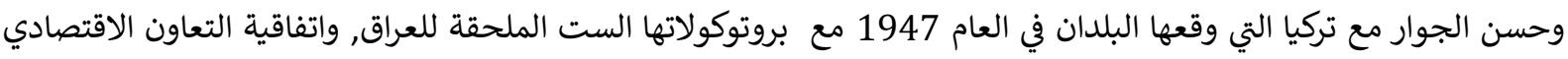




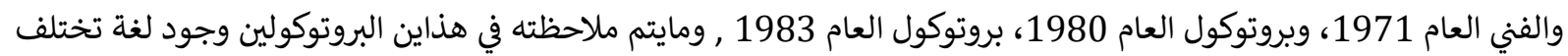

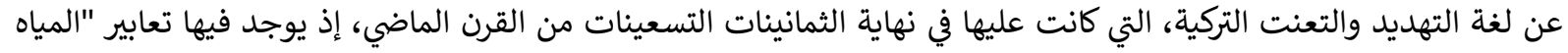

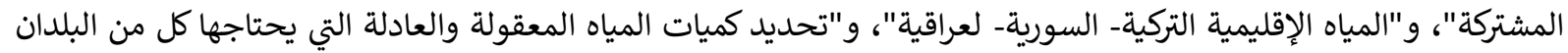

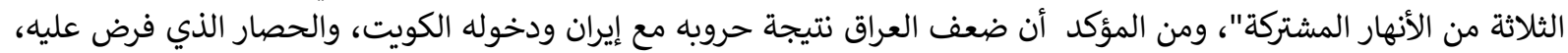

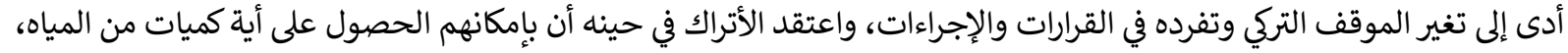

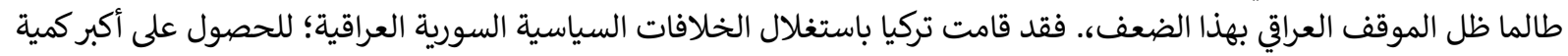

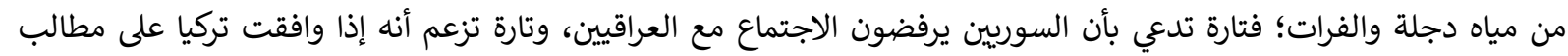

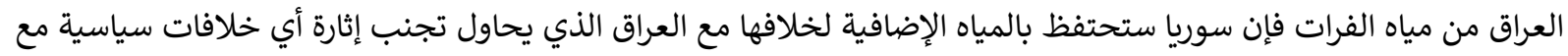

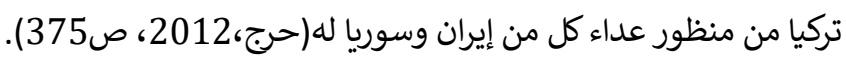

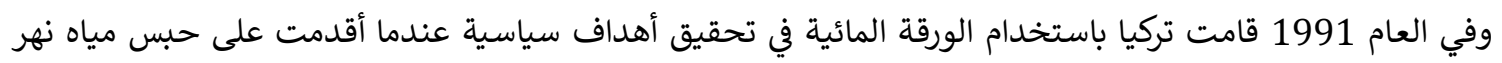

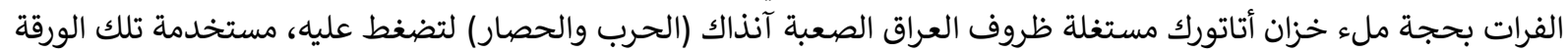

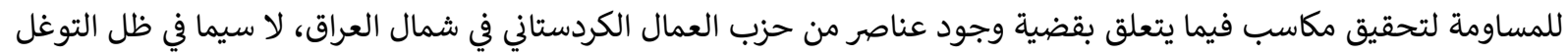

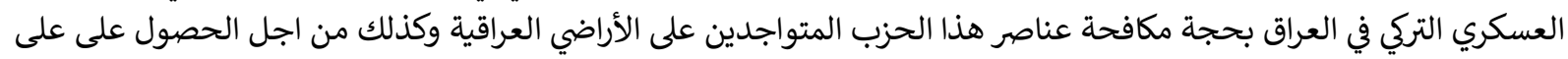

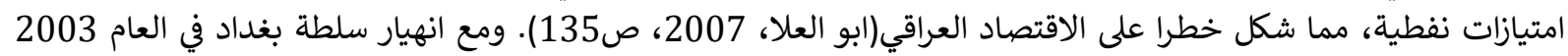

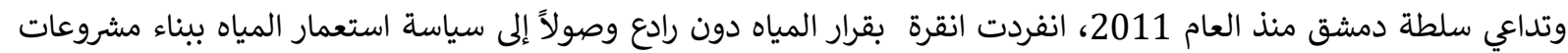

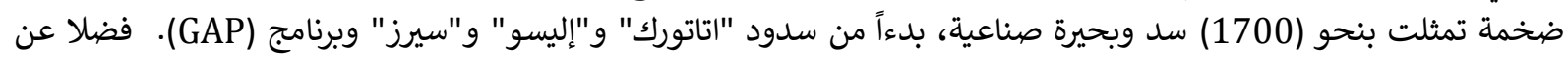

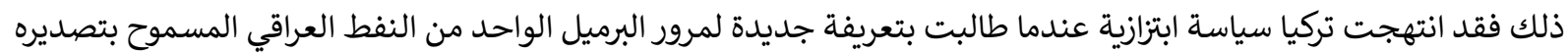

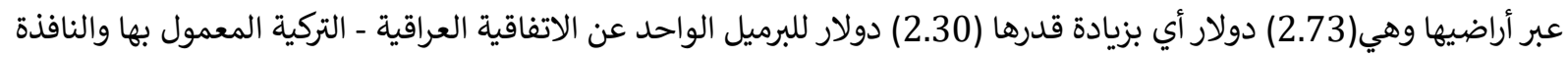

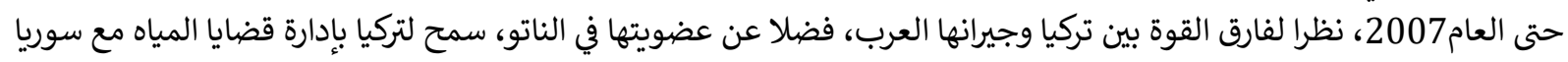

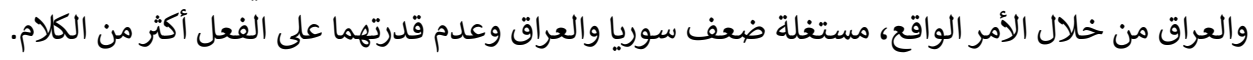

• آليات الدبلوماسية المائية في حل المشاكل المائية العراقية مع تركيا: وأمام الحقائق المذكورة في اعلاه فان فان أي تقدم باتجاه

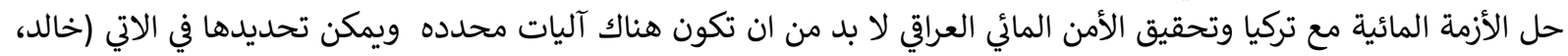

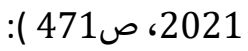
- الآليات على المستوى الاقتصادي:

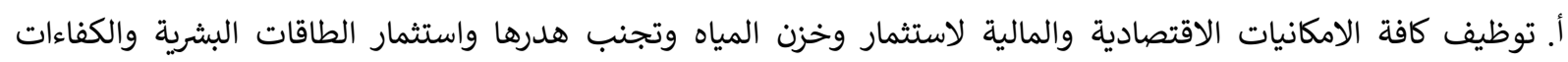

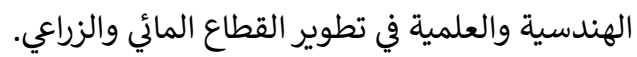

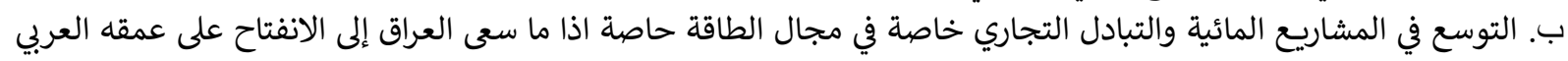

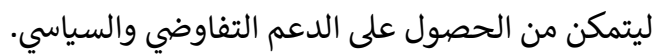

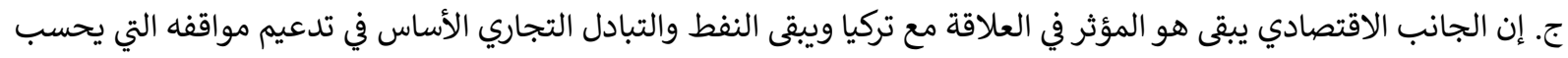

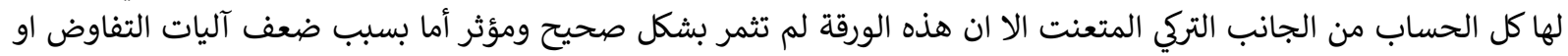

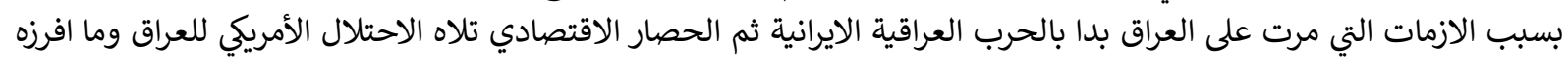

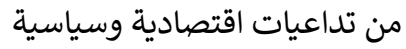

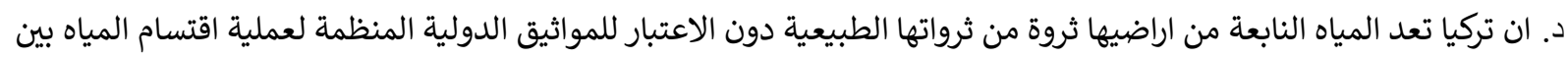

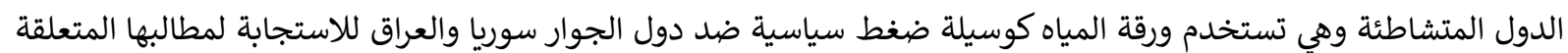

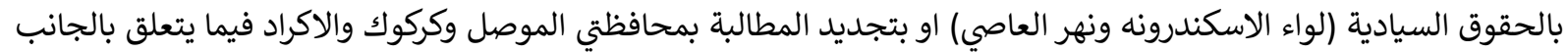

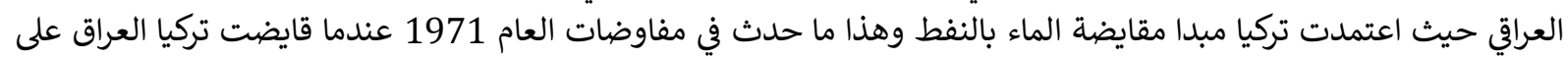

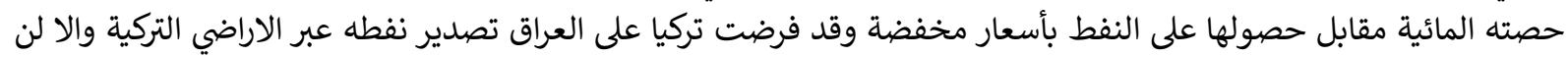

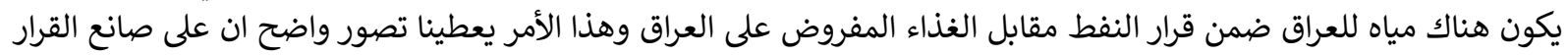

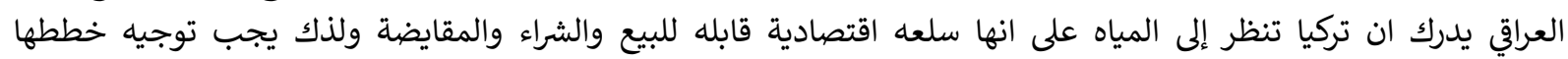

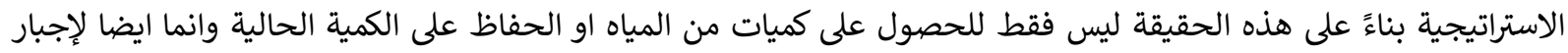

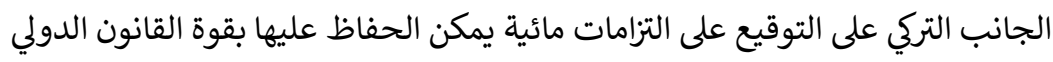

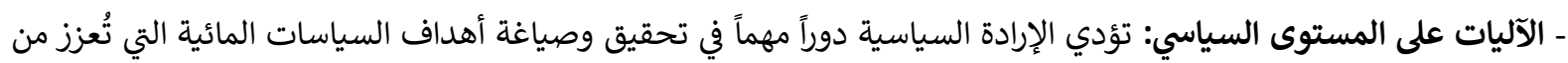

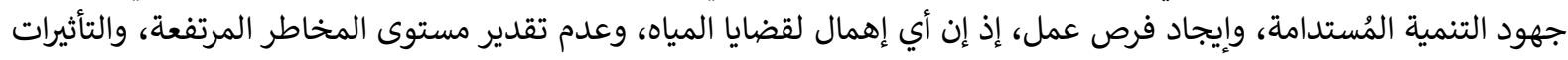

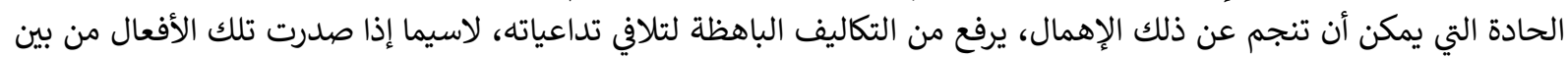


السياسيين وصانعي السياسات (Michael Tran ,2016, P12) لذلك فأن التكامل في عمل المؤسسات الرسمية المعنية

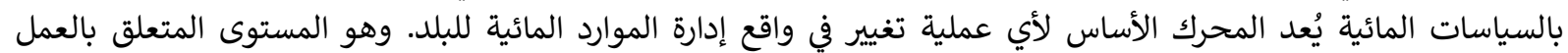

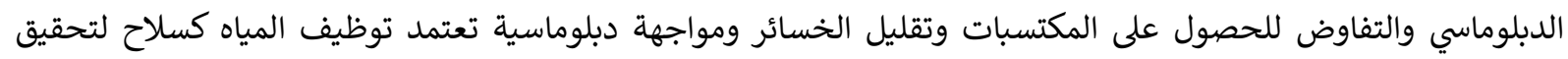

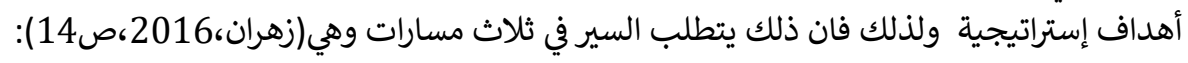

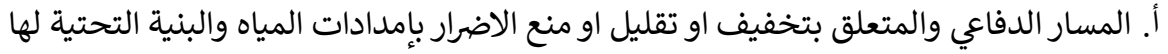

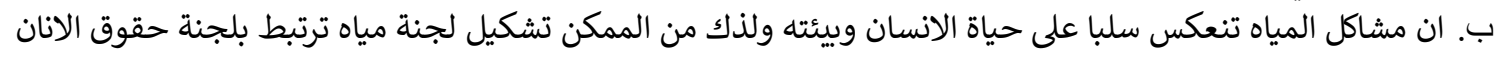

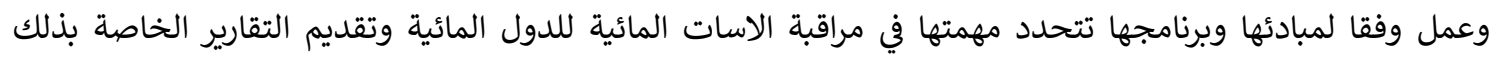
والسعي لتابعة النزاعات المائية.

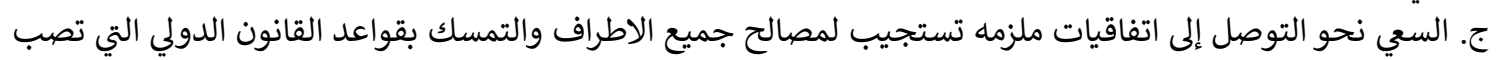
في مصلحة دول المصب والتي تحظر استخدام المياه كسلاح وتفعيل الاتفاقيات التي تصنف عسكرة المياه باعتبارها جريمة حرب. د. توظيف الجانب الأمريكي في الضغط باتجاه حلول واتفاقات عادلة للطرفين في قضية المياه. 


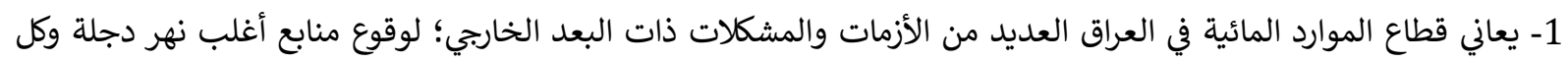

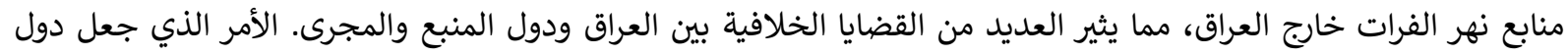

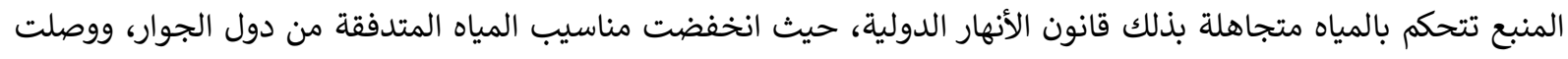

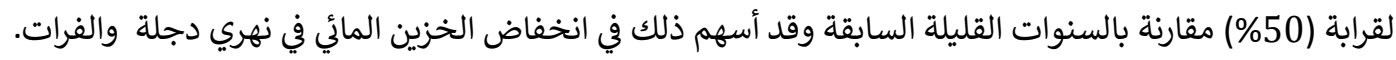

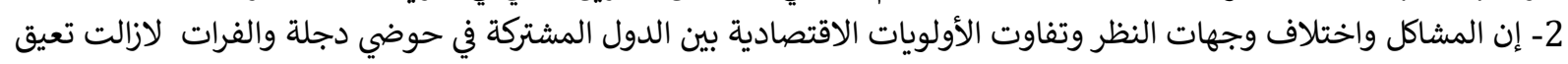

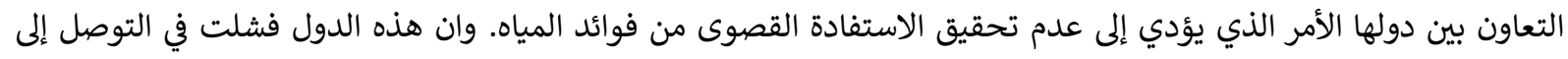

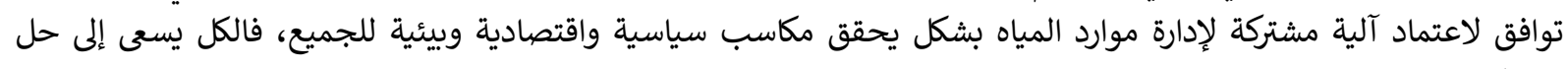

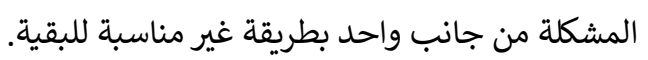

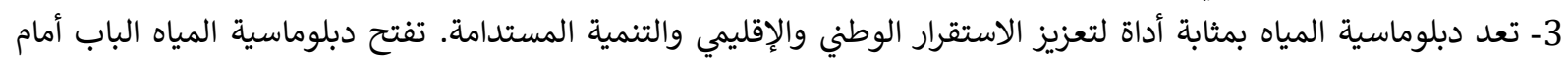

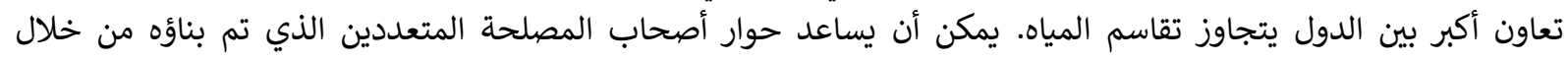

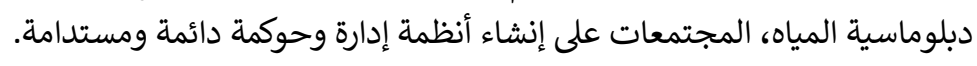

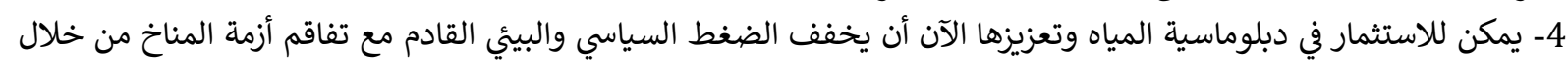

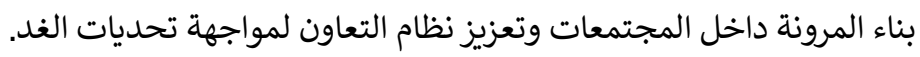

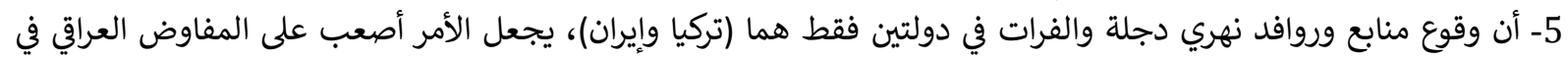

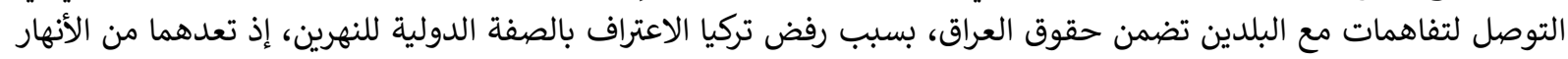

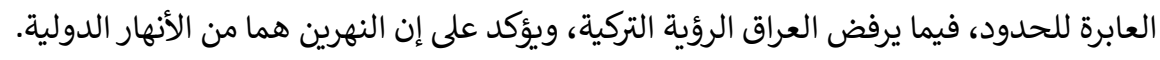

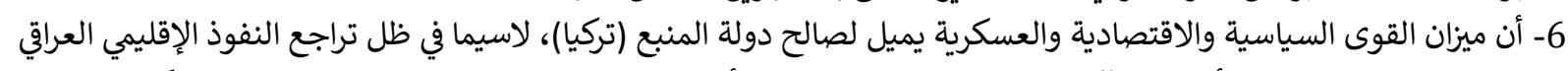

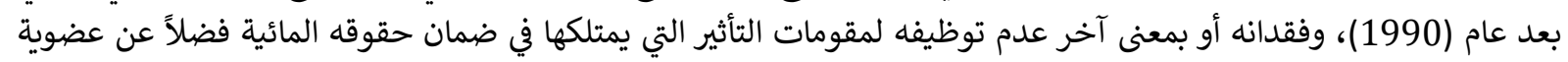

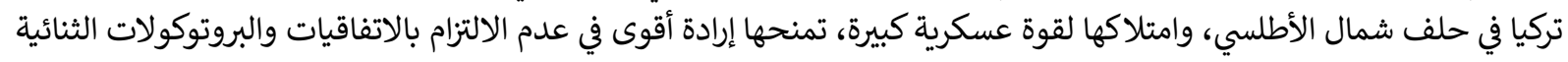
والدولية، التي تنص على تقاسم مياه الأنهار الدولية.

التوصيات:

1- يجب إعطاء الأولوية لتشجيع وتسهيل اتفاقات تقاسم المياه كجزء من أهداف التنمية المستدامة الدولية والمناخ.

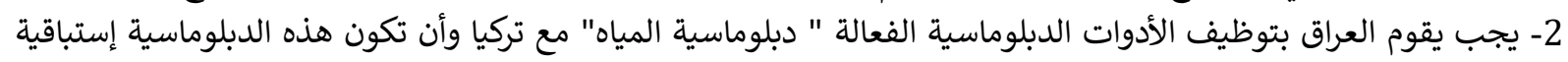

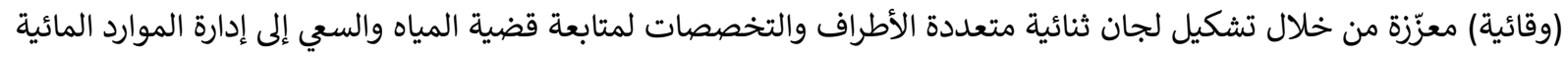

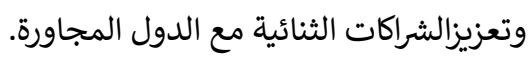

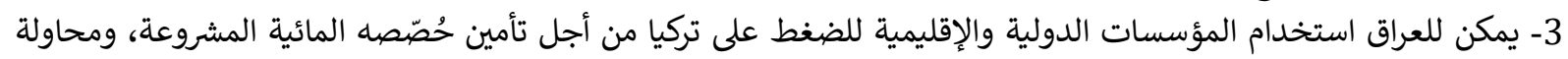

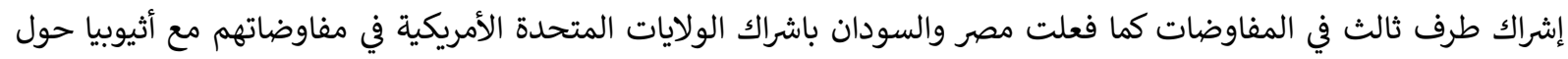
مشاكل سد النهضة الأثيوبي كطرف ثالث. 
ابو العلا،محمد، مشكلات المياه في الشرق الأوسط، ط1، القاهرة: مكتبة الانجلو المصرية، مصر،

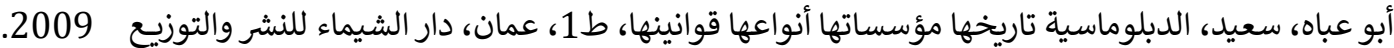

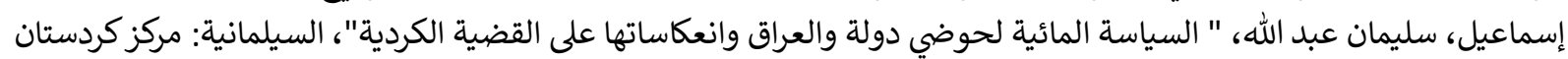
للدراسات الإستراتيجية،العراق،

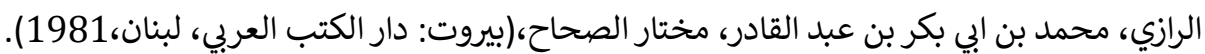

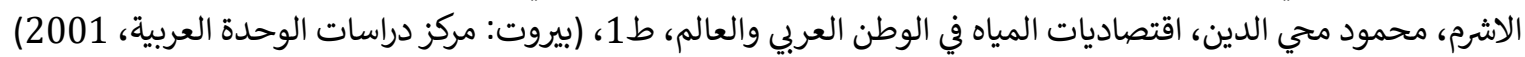

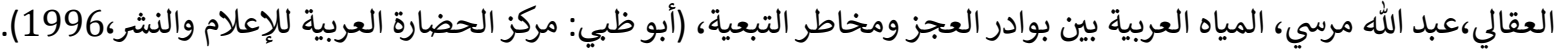

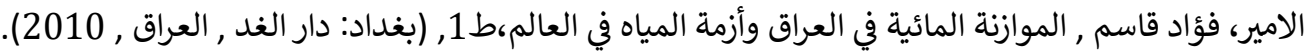

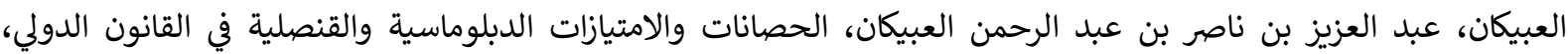

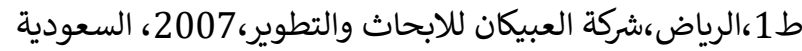

النعيمي،احمد نوري، العلاقات العراقية/التركية في مجال المياه، مجلة العلوم السياسية، العدد 40، كلية العلوم السياسية، جامعة

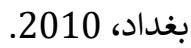

بولوك , جون، عادل درويش، حروب المياه.. الصراعات القادمة في الشرق الأوسط، ترجمة: هاشم أحمد محمد،ط1، الرواد، (القاهرة:

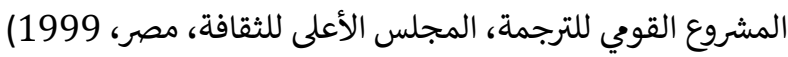

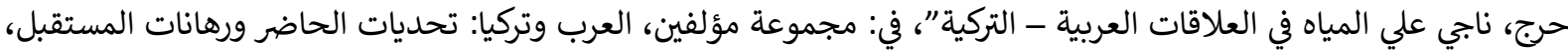

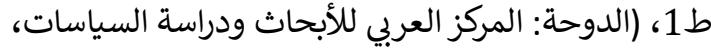

قطر، 2012).

حنوش، زكي، سوريا والمشاريع المائية، في مجموعة مؤلفين، الأمن المائي العربي، أعمال المؤتمر الدولي الثامن لمركز الدراسات

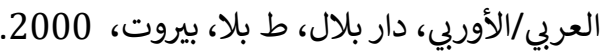

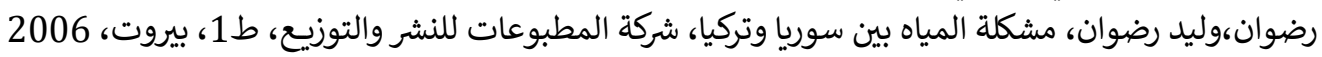

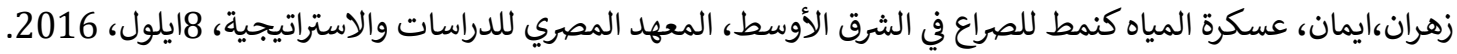

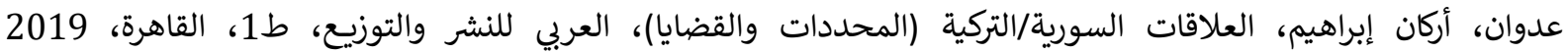

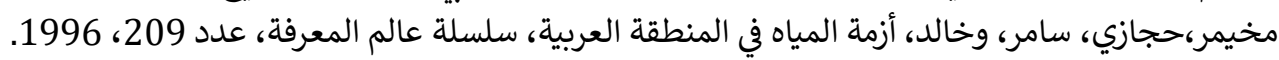

البحوث والدراسات:

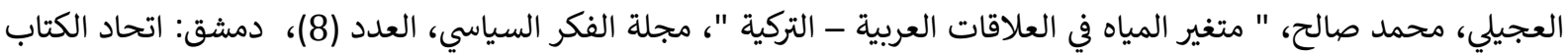

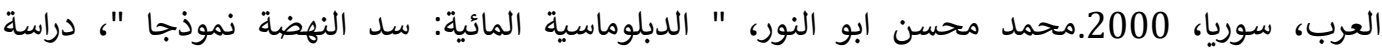

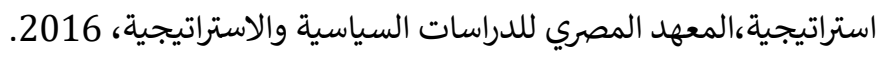

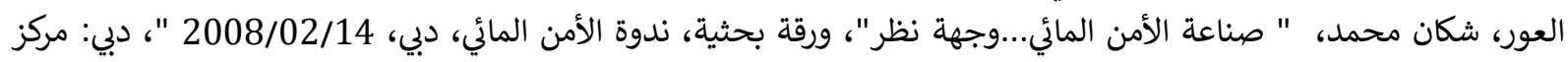

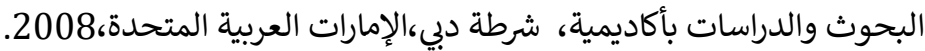

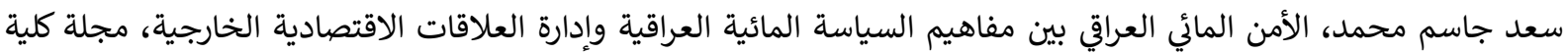

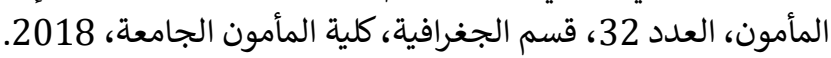

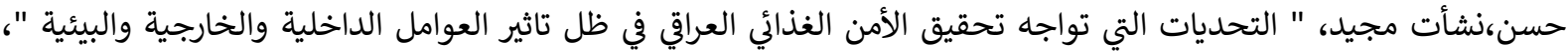

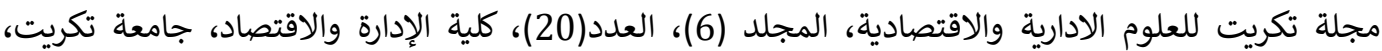

$$
\text { العراق،2010. }
$$

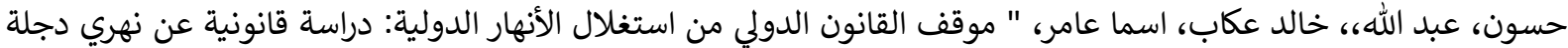

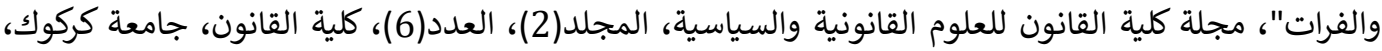

العراق، 2013.

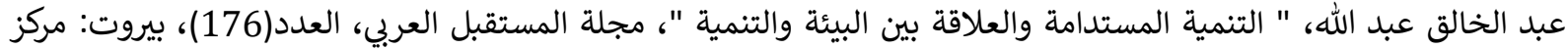

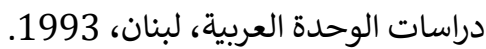

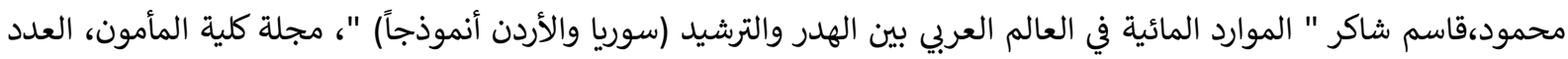
(15)، بغداد، كلية المامون الجامعة، العراق، 2010. 
هالة خالد حميد، "إشكالية الأمن المائي في العلاقات التركية العراقية: دراسة في آليات التعامل الأمثل في قضية المياه"، مجلة قضايا

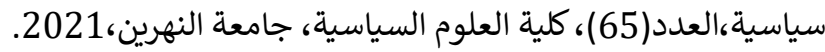

ثالثا: شبكة المعلومات الدولية

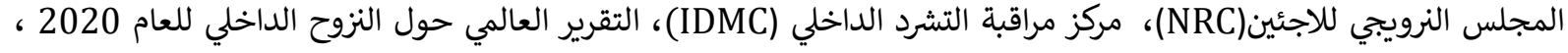

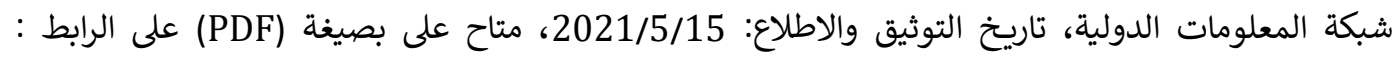
https://www.internal-displacement.org/sites/default/files/inline-files/2020-IDMCGRID-ar.pdf

جيمس ج.ستيوارت، " نحو تعريف واحد للنزاع المسلح في القانون الدولي الإنساني"، المجلة الدولية للصليب الأحمر، العدد(2003(850)

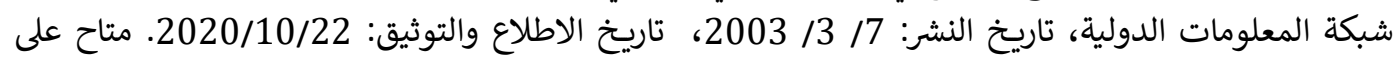

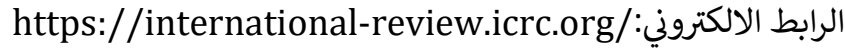

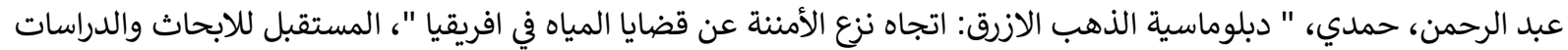

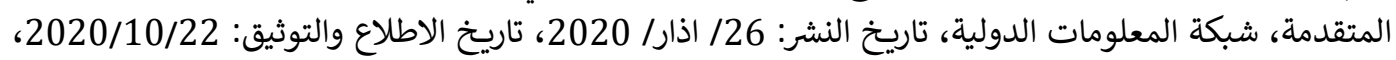

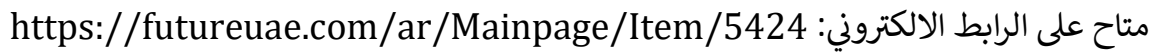

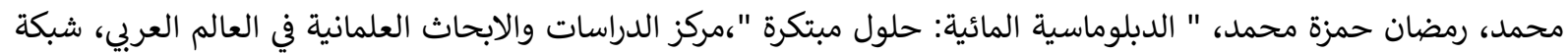

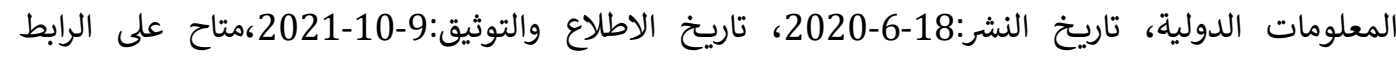

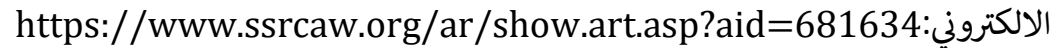

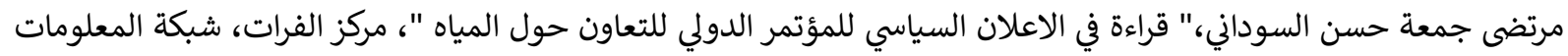

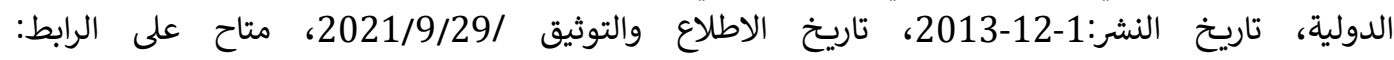
http://fcdrs.com/law/34

نظيف، احمد، " دبلوماسية المياه... البشرية العطشى تحبس الانفاس"، النهار العربي، شبكة المعلومات الدولية، تاريخ النشر:

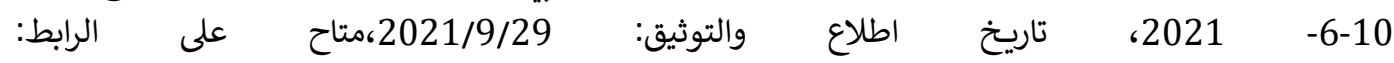
https://www.annaharar.com/arabic/makalat/annahar-alarabi-

\section{English sources:}

Chambers English dictionary, UK, W\&R chambers ltd and Cambridge University press, 1988.

Food and Agriculture Organization of the United Nations, The Water-Energy-Food Nexus: A new approach in support of food security and sustainable agriculture, 2014

World Energy Outlook, Middle East and North Africa Insights, - International Energy Agency, Paris , 2005

Global Water Partnership (GWP), "Increasing Water Security: A Development Imperative," Perspectives Paper, 2012.in https://www.gwp.org/globalassets/global/toolbox.org

Global Water Partnership (GWP), Towards Water Security: A Framework for Action, (Stockholm, Sweden: Global Water Partnership, 2000.in: https://www.gwp.org/globalassets/global/toolbox.org.

Lomborg, Bjorn (2004), Global Crises, Global Solutions ,United Kingdom ,Cambridge University press, 2004.

Oxford advanced learner's dictionary, Sally Wehmeier (Ed), Oxford: Oxford university press, 2004

New Webester's dictionary and the saurus of the English language, lexicon publications, inc, 1996.

Mahdi, Ali, S. MQutaiba, A. S., Hussan, M. and Al-Azawi, F. W., "Fluctuating rainfall as one of the important cause for desertification in Iraq", J. of Environment and Earth Science, 3, 2, 2013.

The United Nations ,World water crisis worsened by corruption, repression: UN report 20 February http://www.un.org/apps/news/story.asp?NewsID $=17551 \& \mathrm{Cr}=\& \mathrm{Cr} 1$ 
Tianyi Luo, These 20 Water-Stressed Countries Have the Most Solar and Wind Potential, May 10, 2018, Available in: https://www.wri.org/blog/2018/05/these-20-water-stressedcountries-have-most-solar-and-wind-potential

Robert S. McNamara, The Essence of Security, (New York: Harper Press, 1968 
THE SUBJECT BETWEEN SYNTAX AND SEMANTICS

Bekir MEHMETALI 


\title{
THE SUBJECT BETWEEN SYNTAX AND SEMANTICS
}

\author{
Bekir MEHMETALI $^{1}$
}

\begin{abstract}
:
The science of grammar is the basis on which the sciences of the Arabic language are based, and in which its fruits are manifested, it is the science that studies the structure and the sentence, and the single word has no value unless it is organized into a sentence or structure, and it has no useful meaning, and no eloquence if words and pictures are not combined in a useful sentence that exists on grammatical rules. The science of grammar studies the grammatical elements within the sentence, whether they are essential or preferred elements, including the subject, which is an essential pillar in the actual sentence, and has settled in the minds, and in grammatical rules that the subject is a raised noun that performs the known act or what takes its place, and by checking and scrutiny in language books it caught my attention. That the subject may not exist in the verb in terms of meaning and significance, and if it is raised, the known verb is attributed to it grammatically, and the noun may be active in the meaning and connotation despite the fact that the known verb or what took its place from a source and others are not ascribed to it grammatically, and this is a lot. This issue in this research is for the purpose of distinguishing between the grammatical subject and the semantic subject, and here lies the importance of the research, and the motive for it, based on what was mentioned in the books of the advanced and later grammarians of the Arabic language, citing the evidence they cited, analyzing them, commenting on them, and adding the Qur'an to them. Arabic poetry is old, and modern, striving as much as possible to clarify the rhetorical aspect of this issue; The research will be a modest contribution to the service of the Arabic language and scientific research, following the descriptive and analytical approaches.
\end{abstract}

Key words: Grammar, Subject, Semantics, Arabic, Language.

\section{الفاعل بين النحو والدلالة}

http://dx.doi.org/10.47832/ijhercongress2-3

${ }^{1}$ Kilis7Aralık University, Turkey, bekler2006@ gmail.com, https://orcid.org/0000-0003-2783-8543 


\section{باكير محمد علي2}

الملخص:

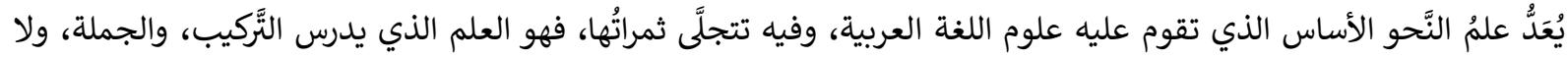

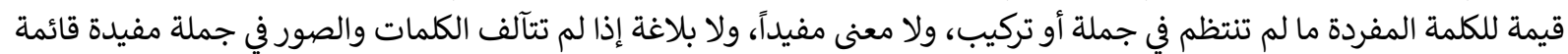

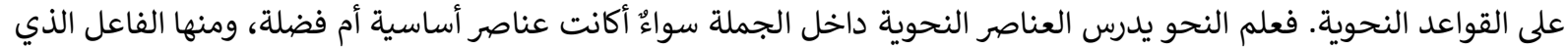

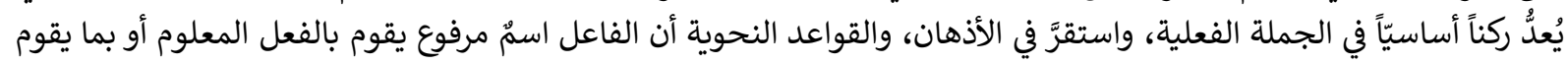

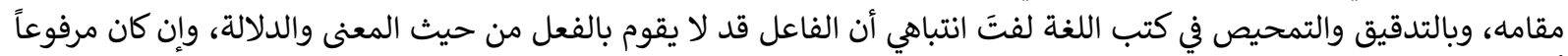

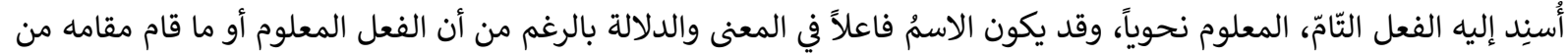

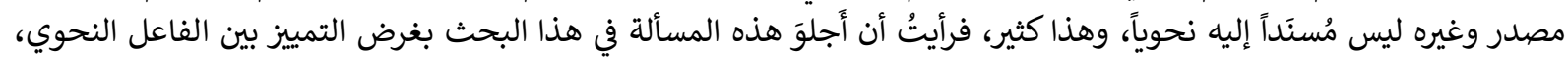

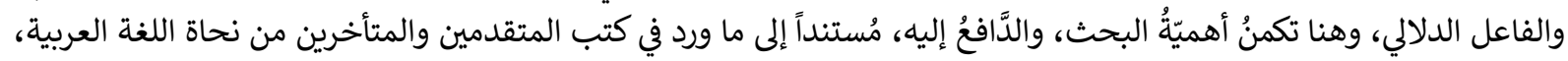

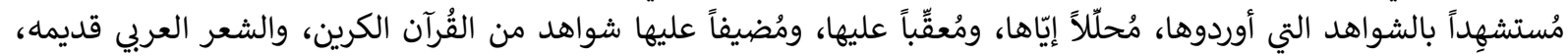

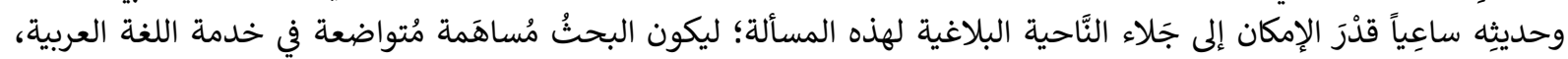

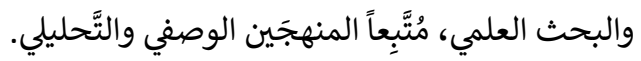

الكلمات المفتاحية: النحو، الفاعل، الدلالة، العربية، اللغة.

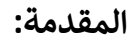

من المعروف المشهور لدى الباحثين في اللغة العربية ودارسيها أن اللغة العربية كانت في عهدها الأول قبل تقعيده سليقة

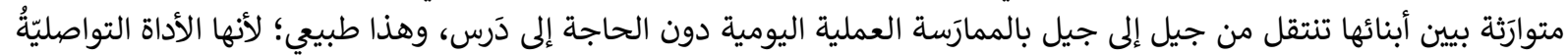

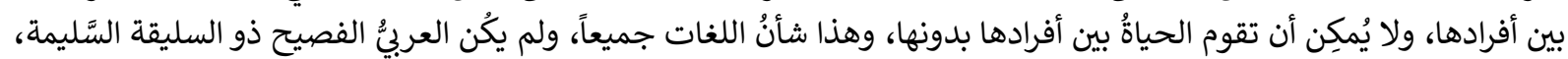

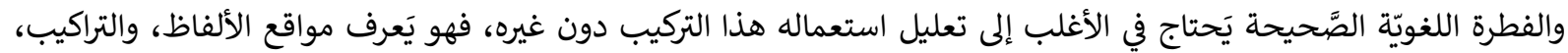

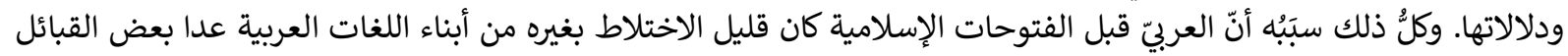

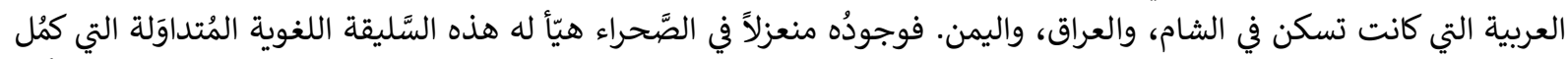

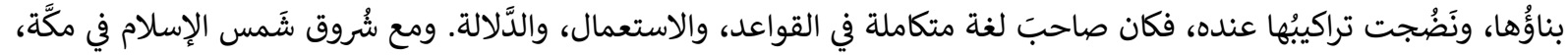

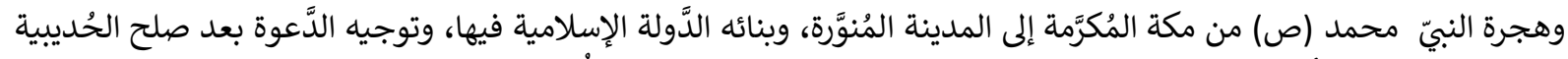

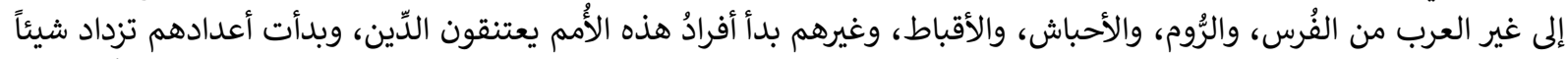

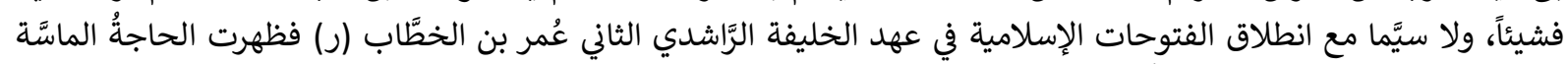

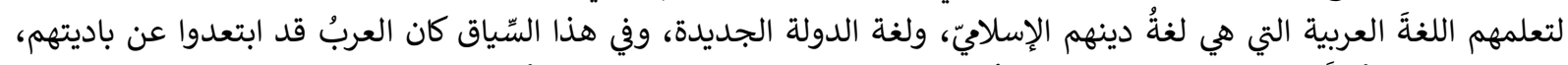

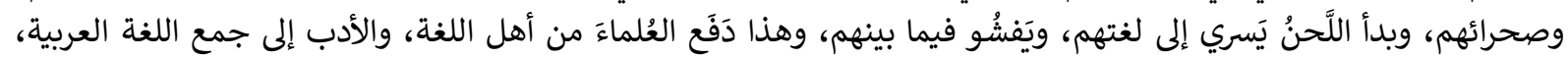

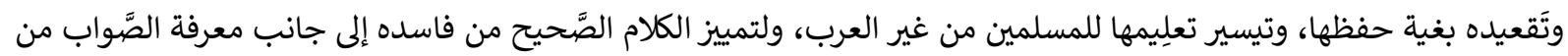

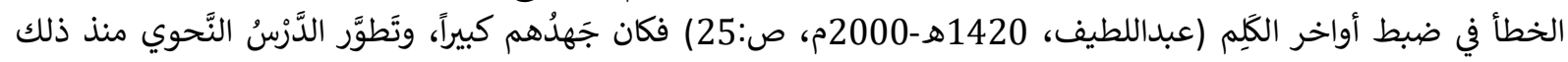

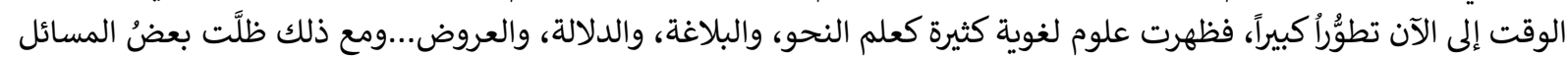

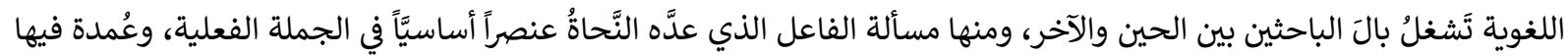

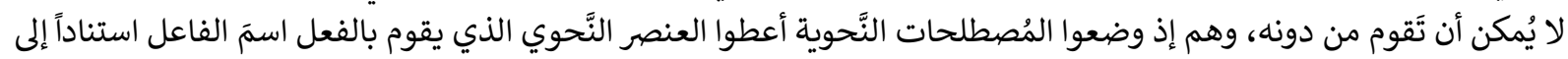

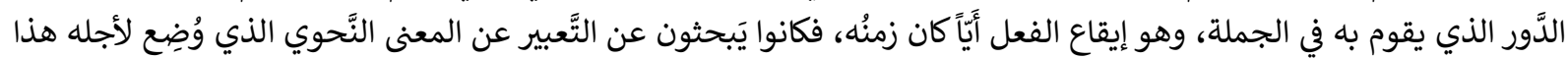

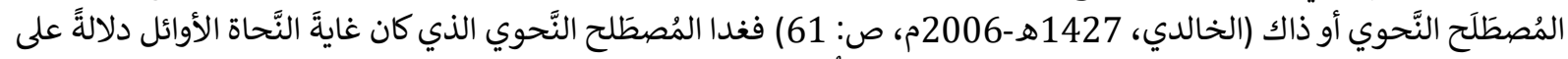

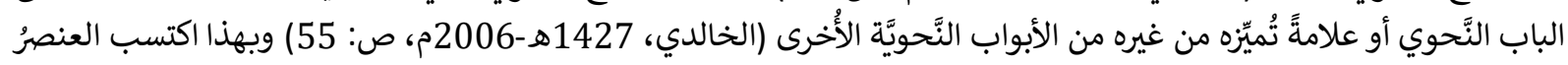

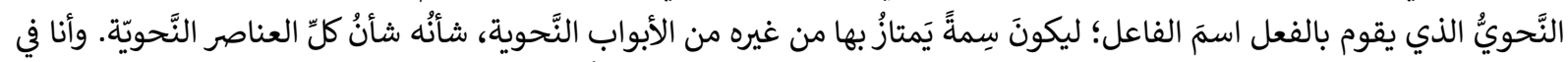

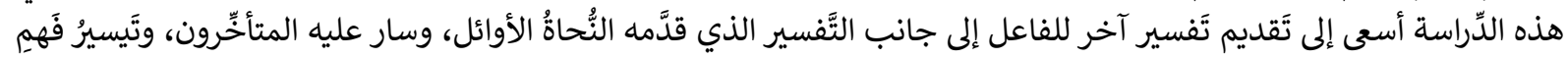

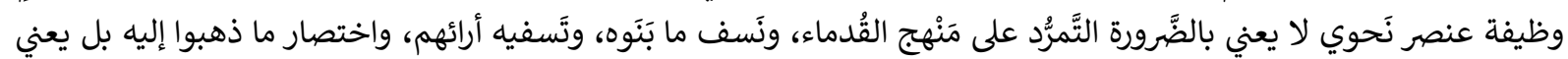

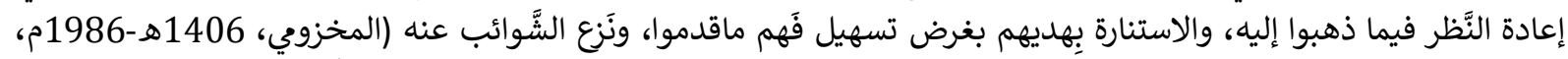

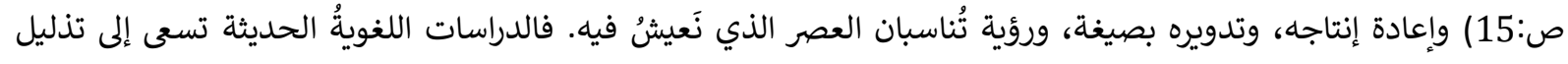




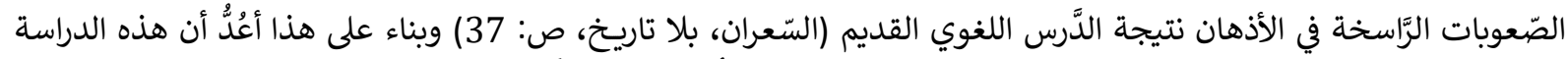

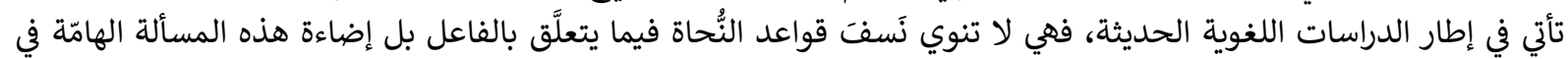

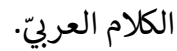

\section{2.العلاقةُ بين علم النَّحو والدَّلالة: 2}

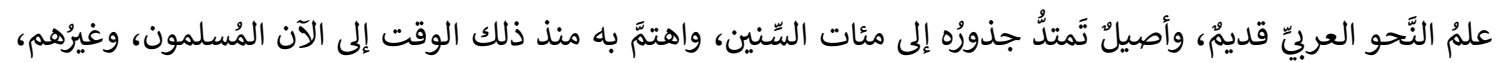

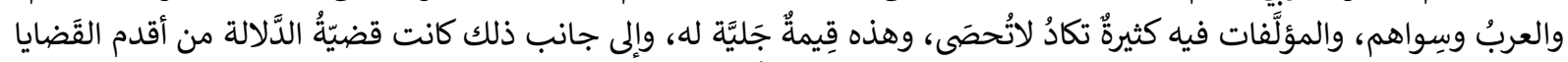

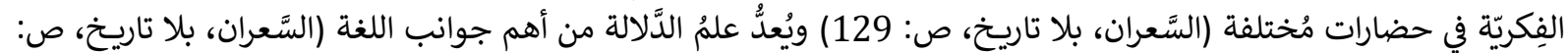

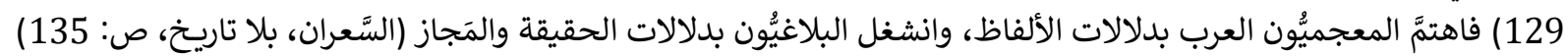

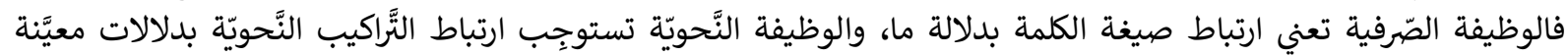

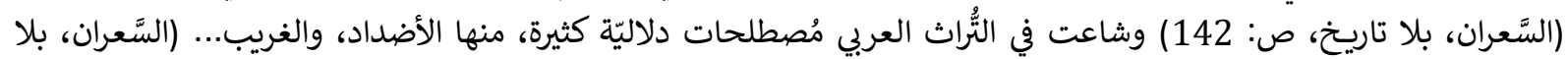
تاريخ، ص: 152-153). (153)

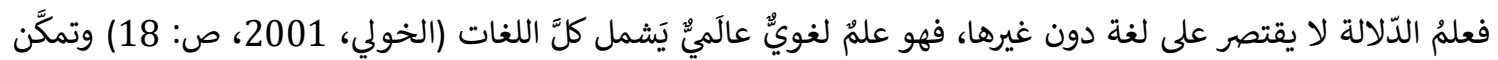

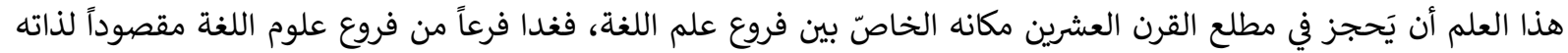

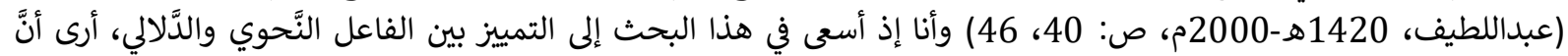

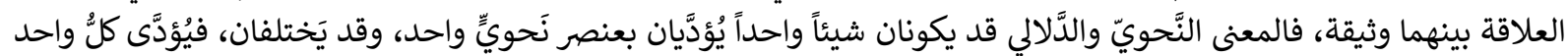

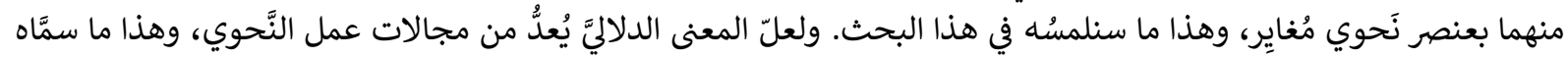

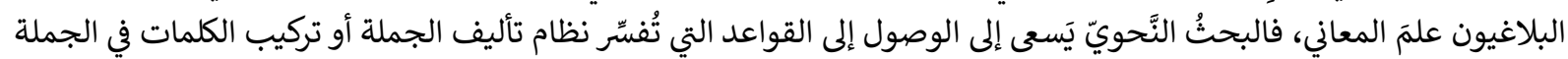

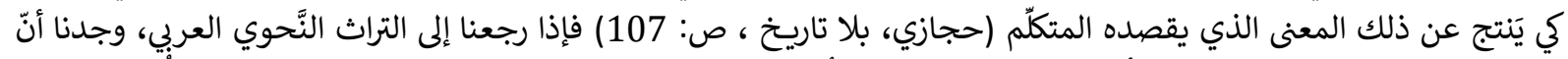

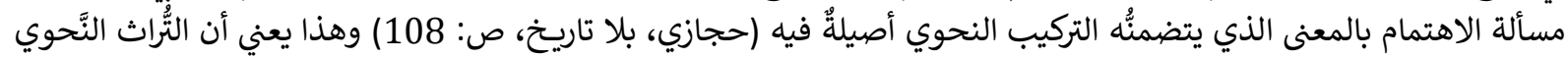

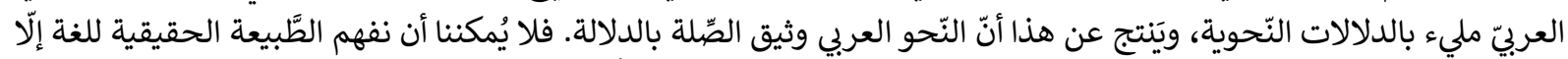

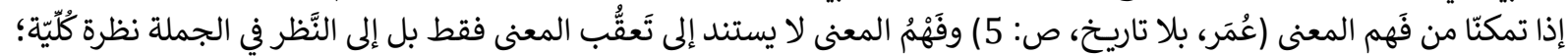

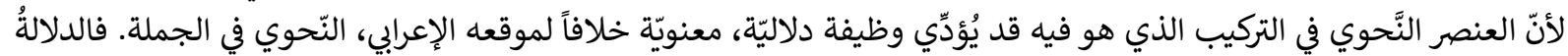

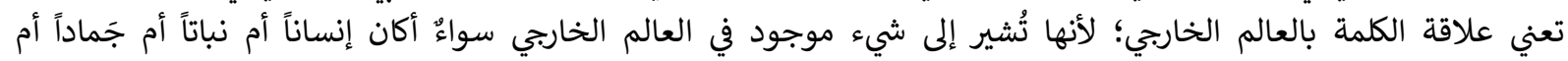
حَيواناً...(الخولي، 2001، صالة صلمة 25).

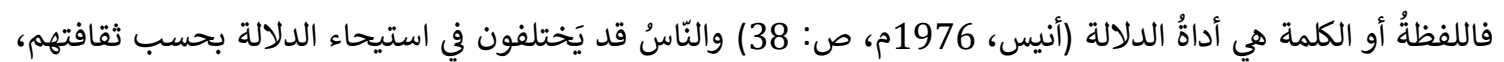

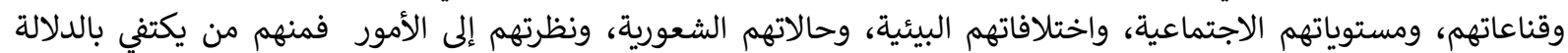

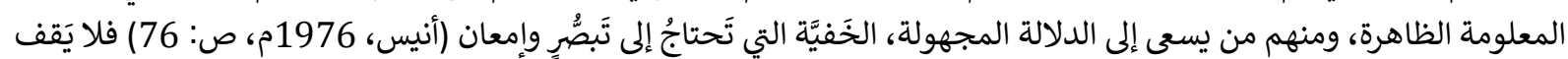

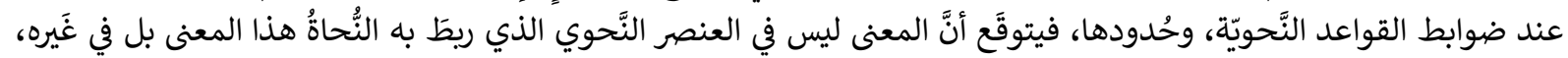

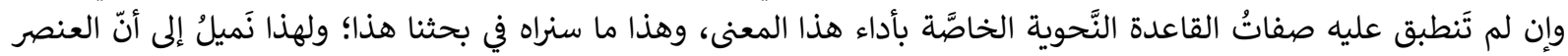

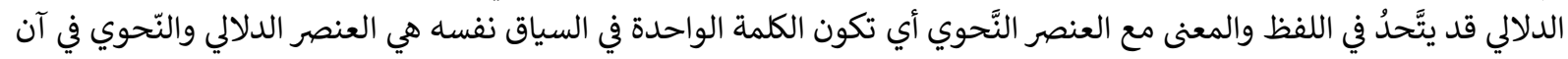

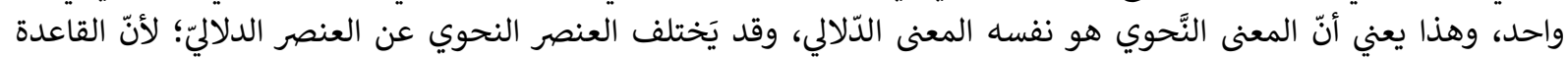

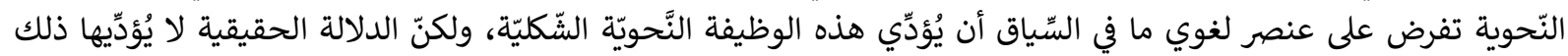

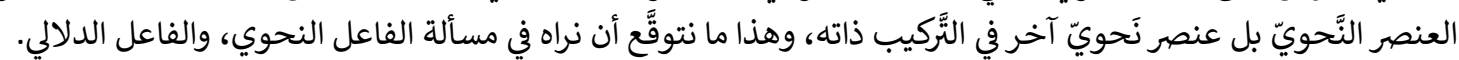

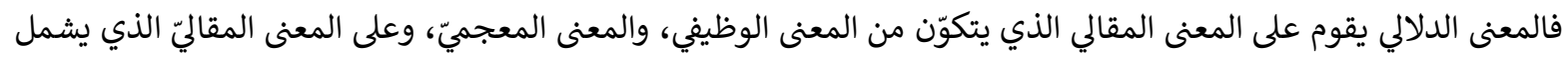

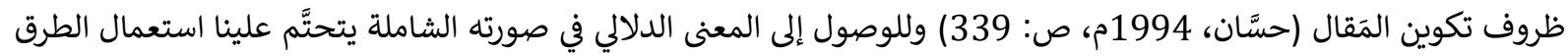

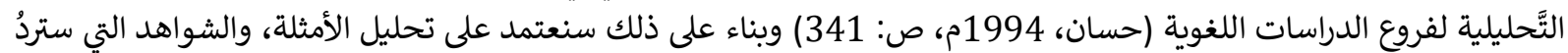

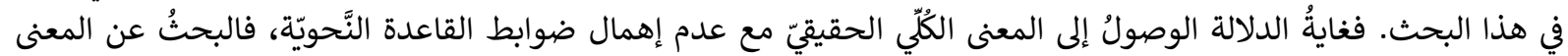

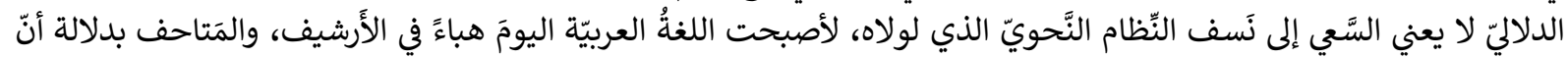

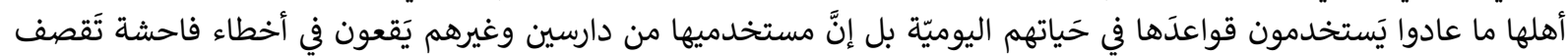

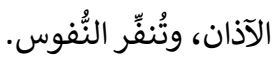

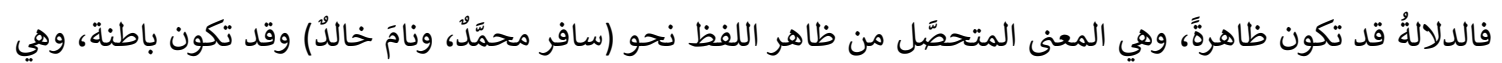

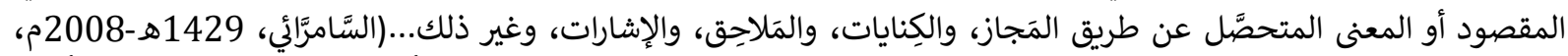

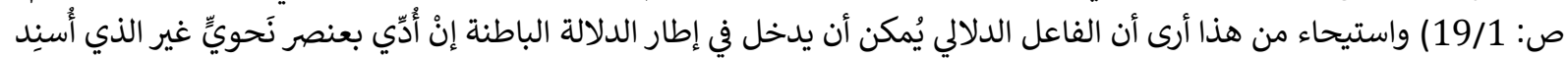
إليه الفعلُ نَحويًَاً. 


\section{3. الفرق بين الفاعل النَّحويّ والدلالي:}

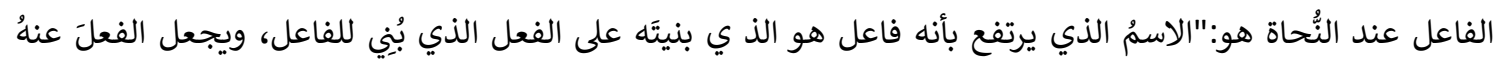

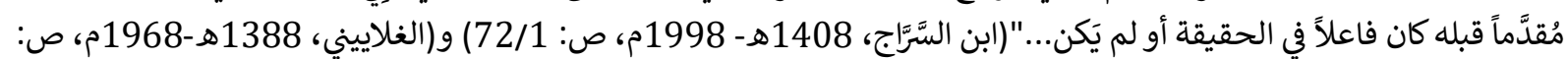

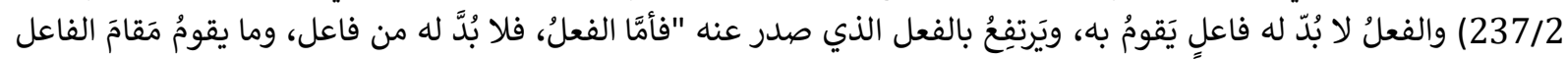

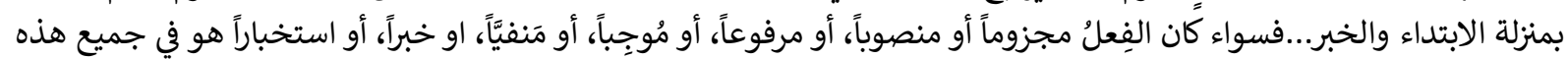

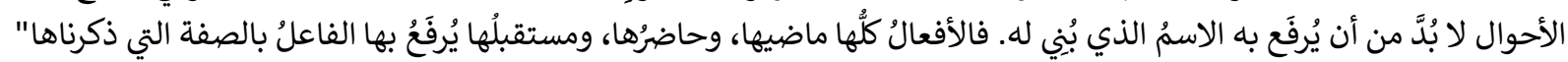

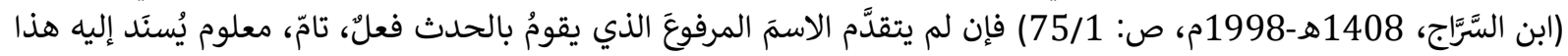

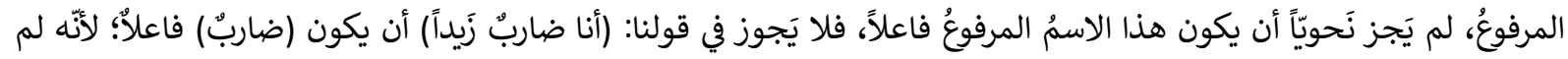

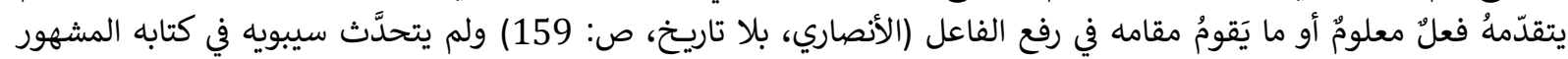

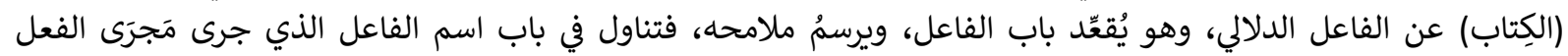

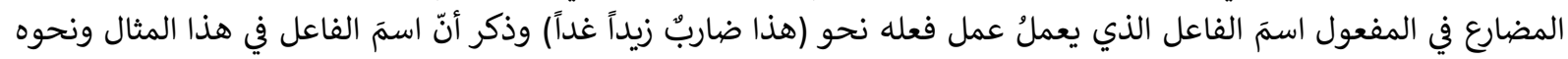

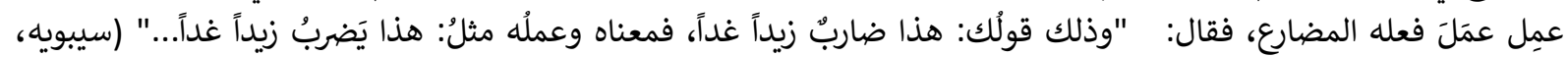

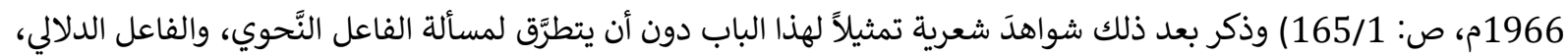

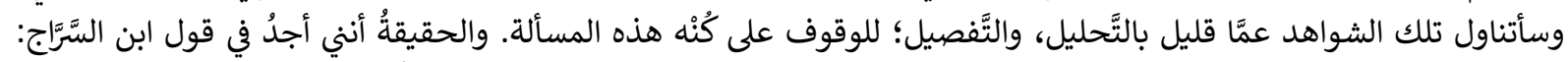

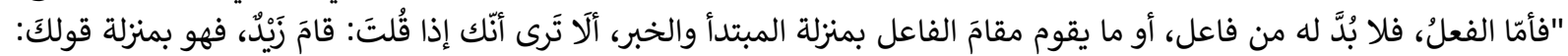

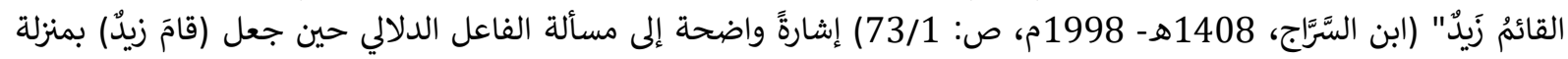

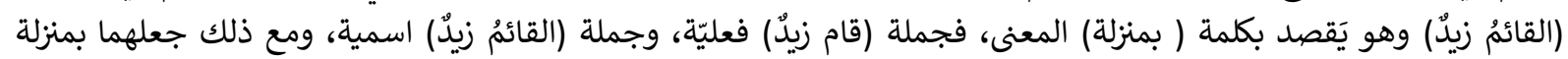

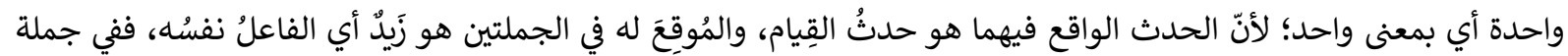

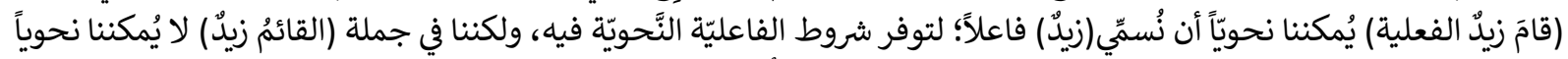

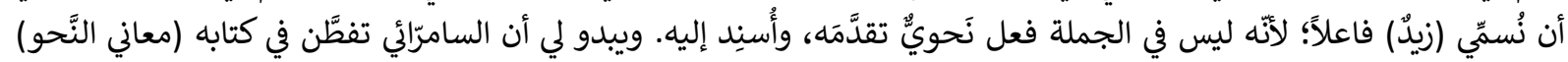

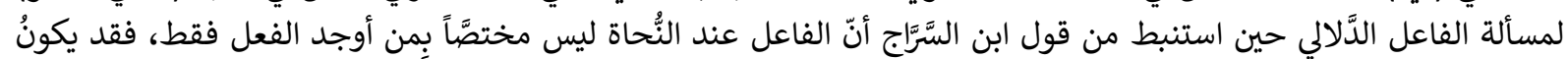

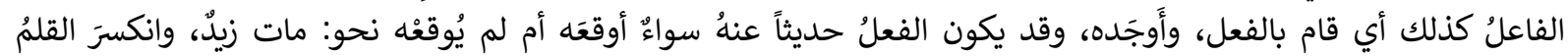

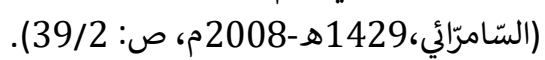

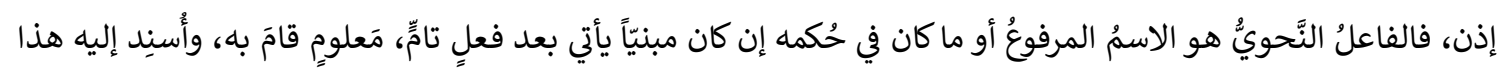

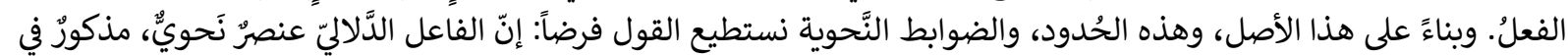

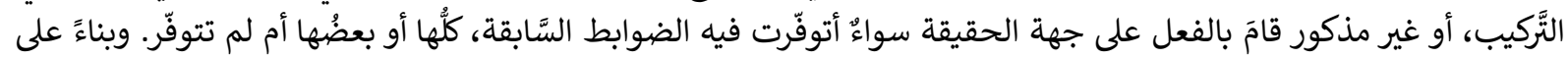
هذا التَّفريق بينهما سأتناول المواضع مذرك التركيبيّة للفاعل النَّحوي والدلالي.

\section{4. - المواضع التركيبيّة للفاعل النَّحوي والدلالي:}

تتعدَّد المواضع التركيبية النَّحوية للفاعل الدلالي، ومنها:

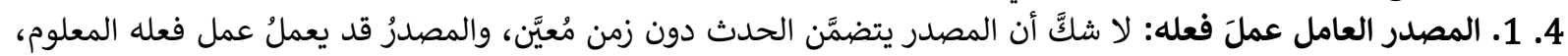

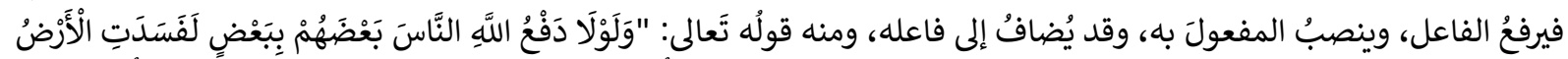

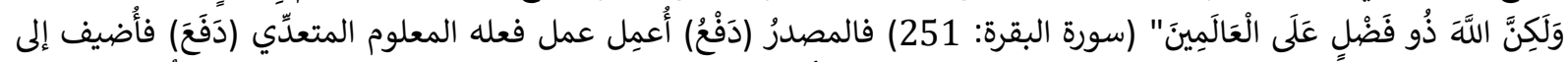

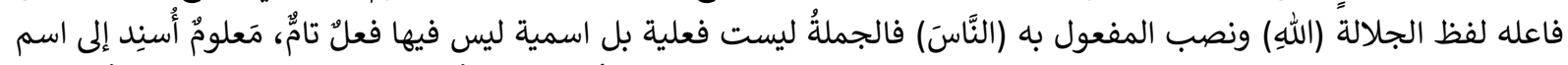

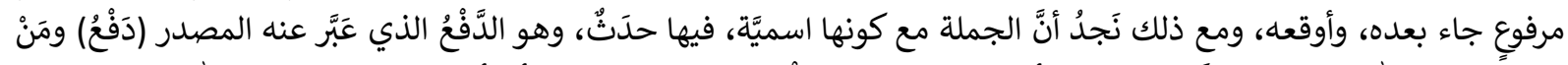

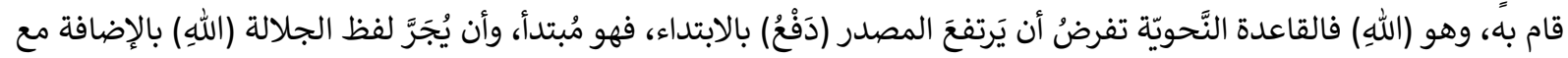

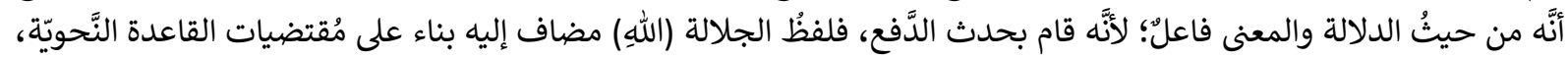

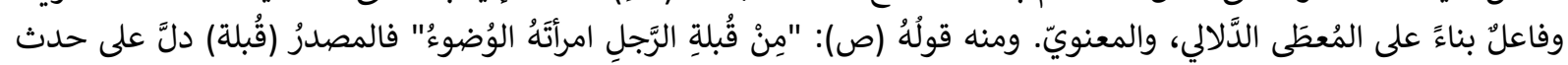

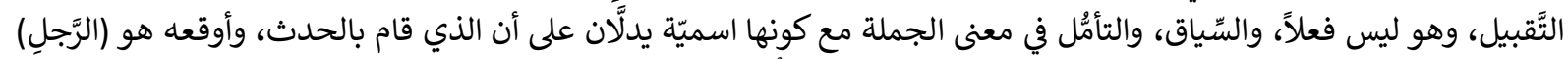

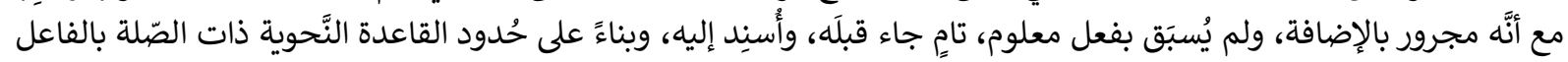

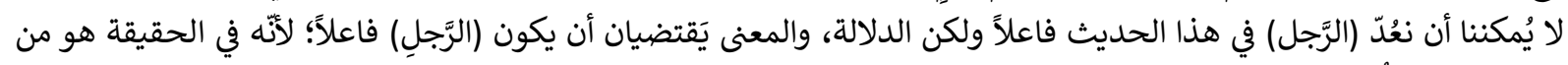

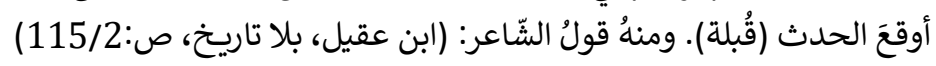

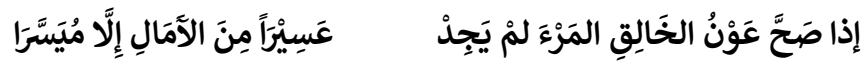




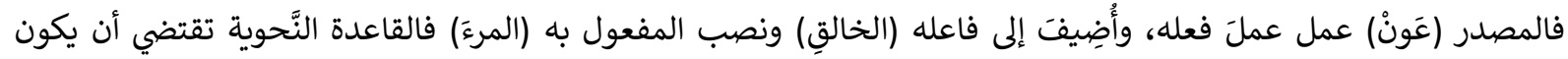

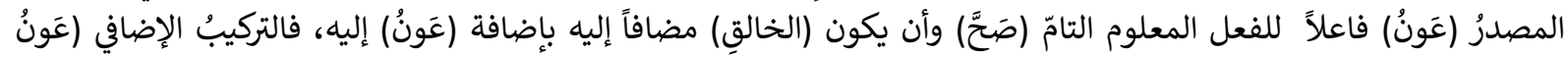

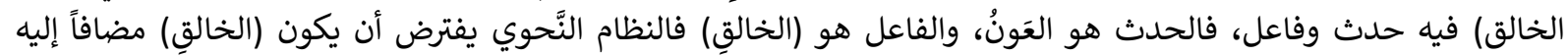

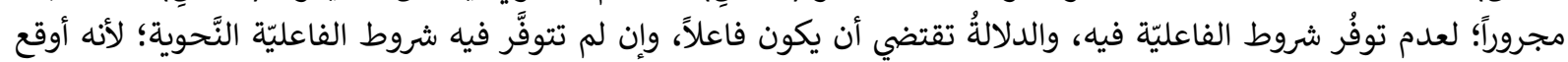

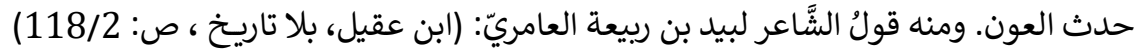

\section{حَتَّى تَهَجَّرَ في الرَّوَاحِ وهَاجَهَا}

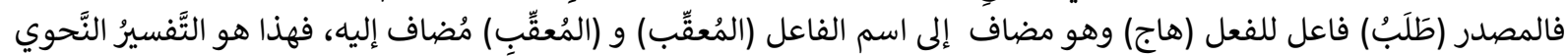

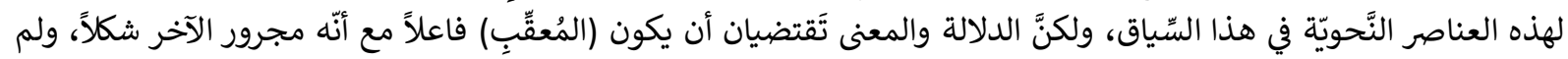

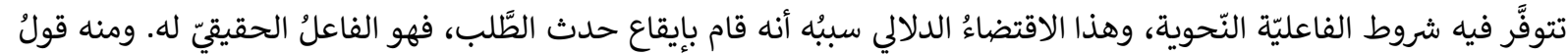

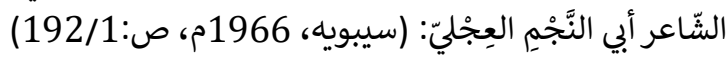

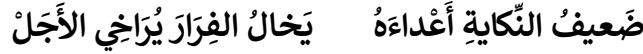

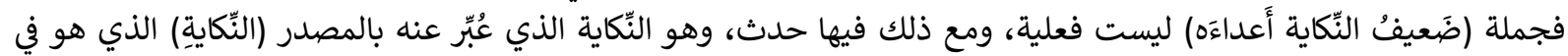

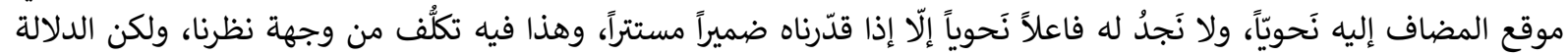

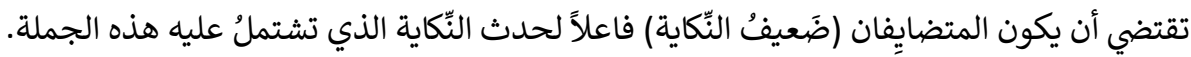

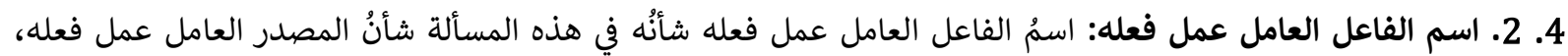

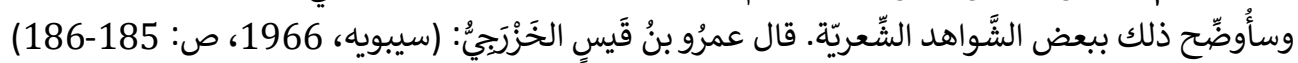

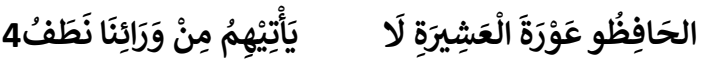

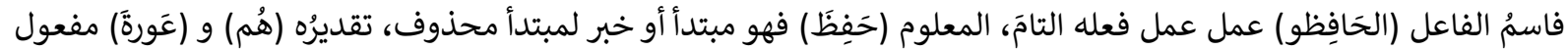

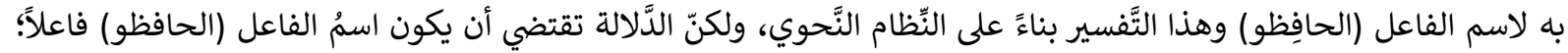

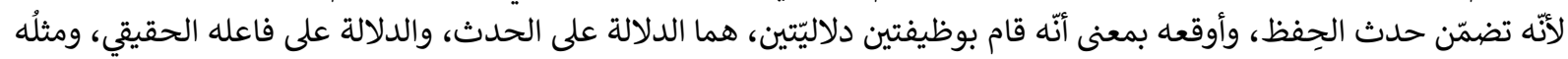

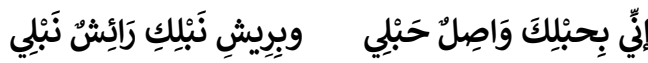

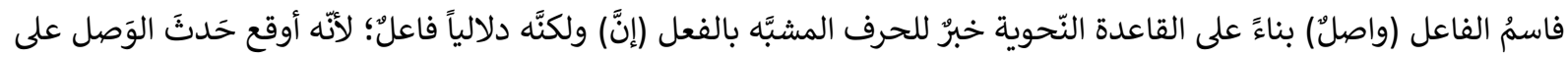

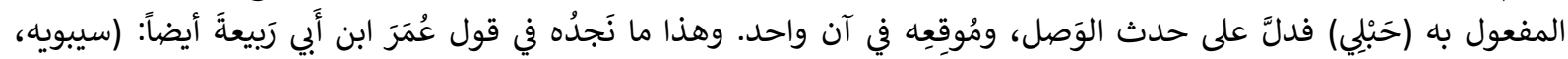

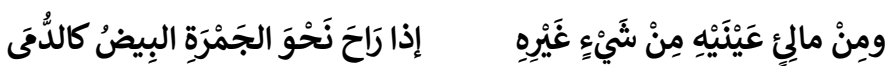

1966م، ص: 165 بع: 1965)

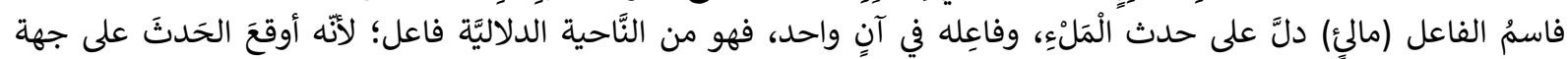

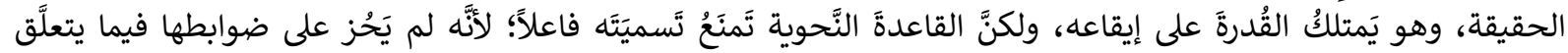

بالفاعليّة.

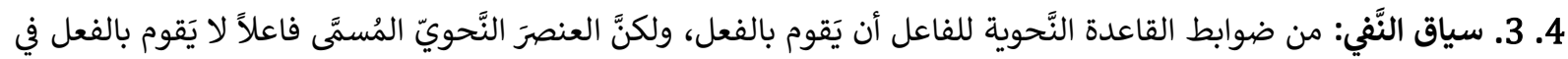

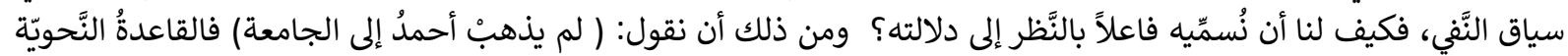

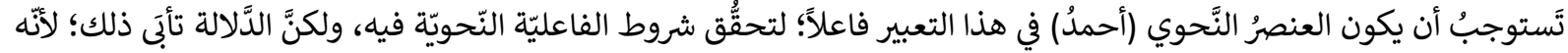

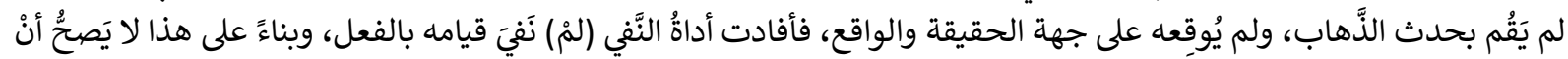

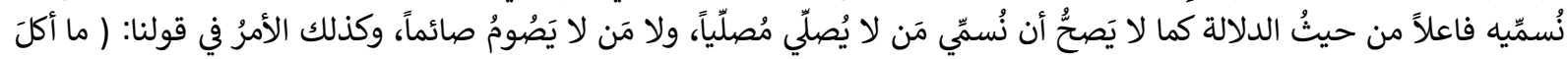

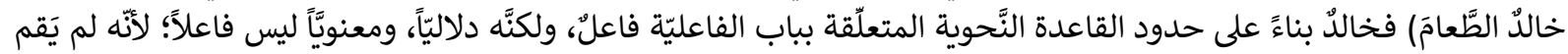

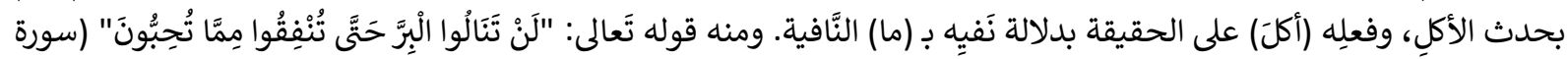

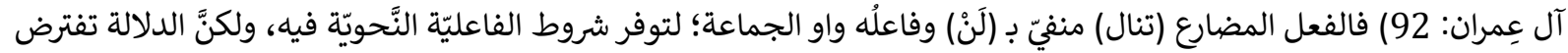

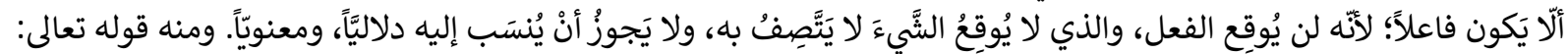

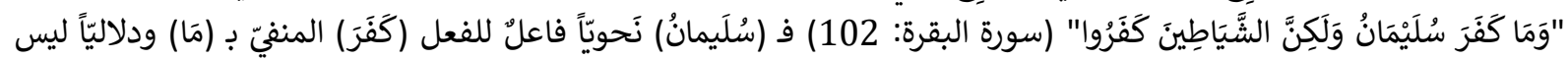

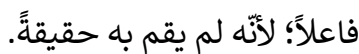

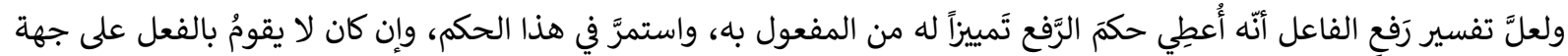

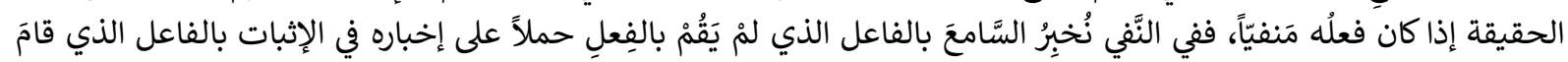




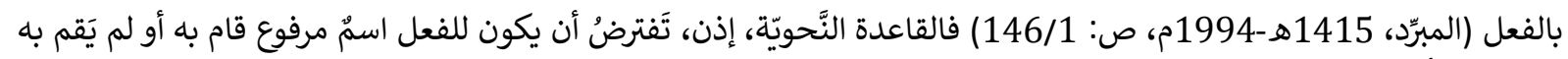

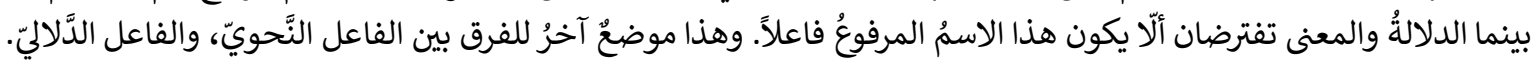

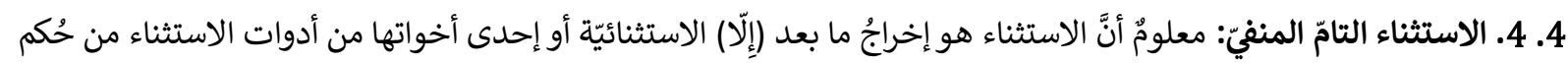

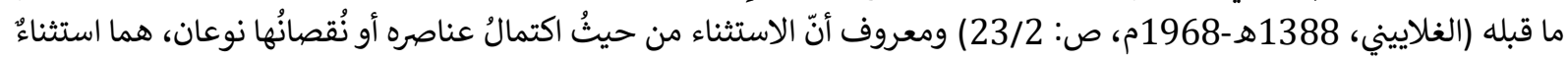

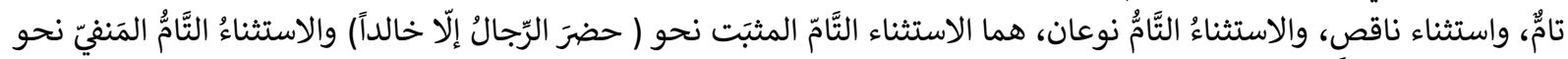

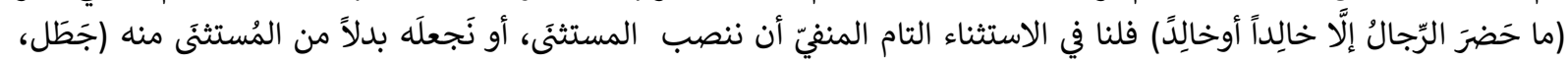

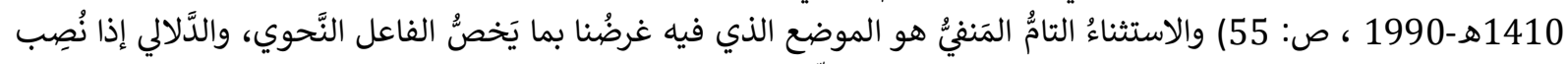

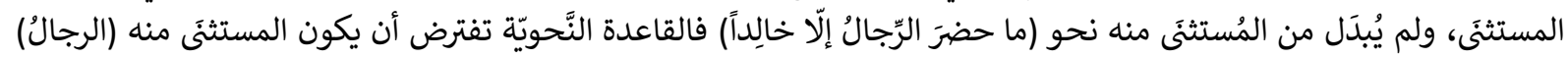

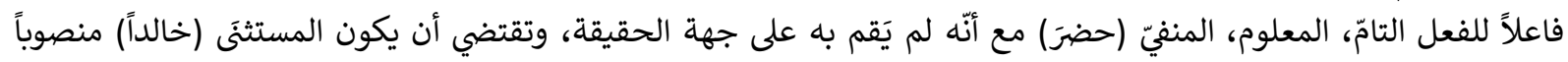

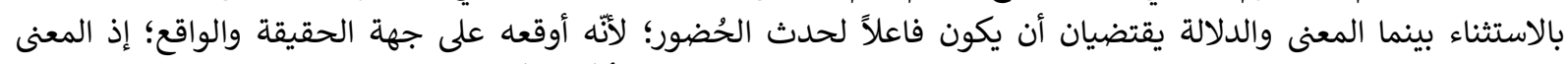

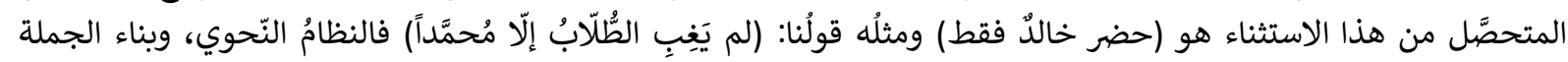

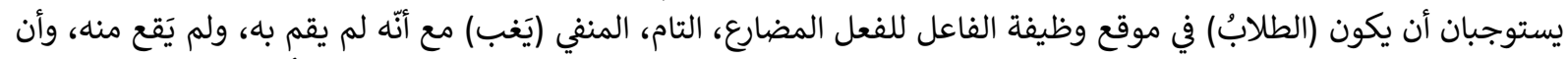

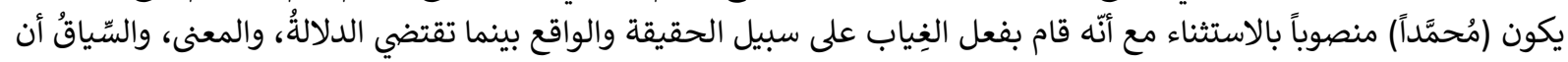

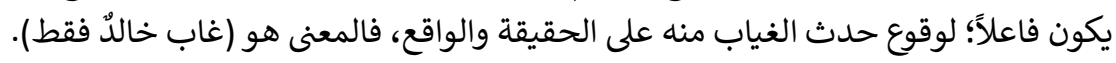

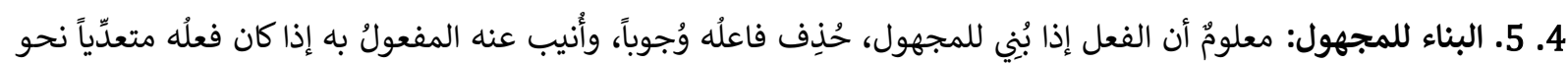

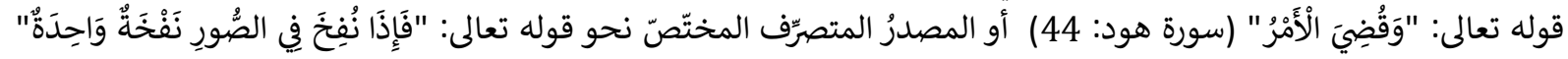

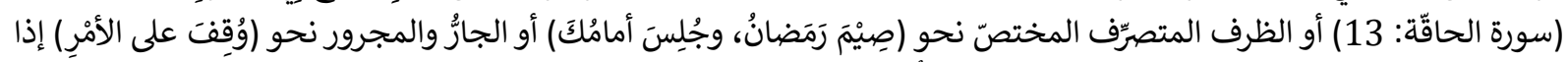

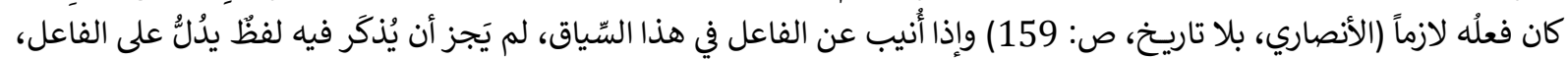

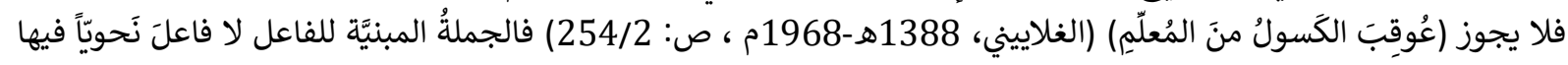

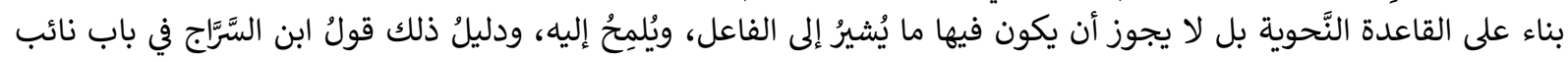

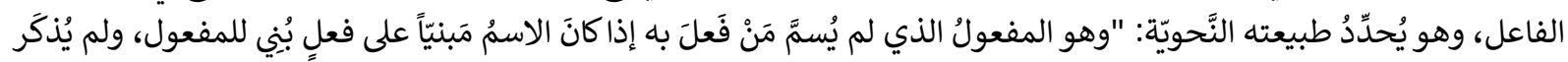

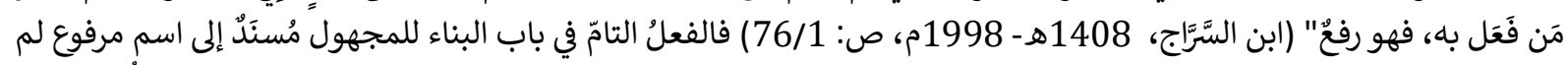

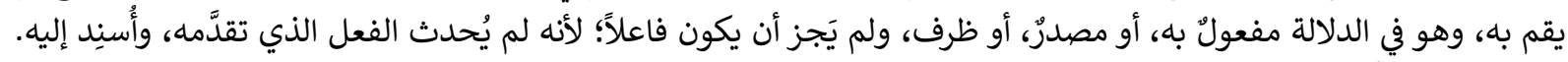

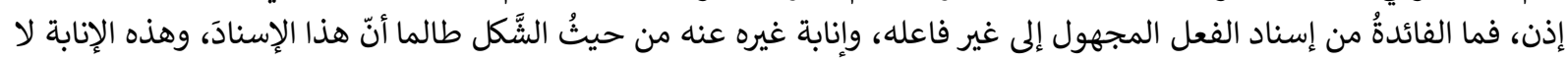

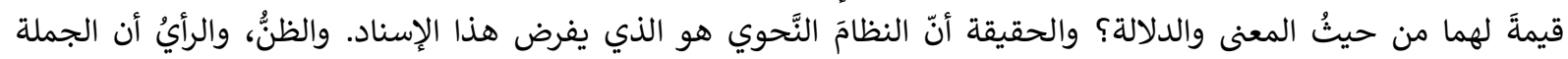

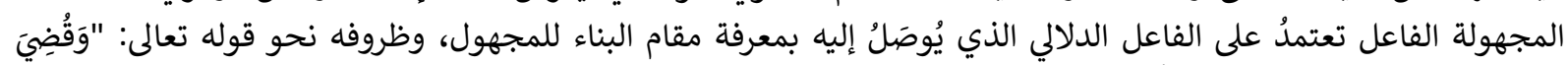

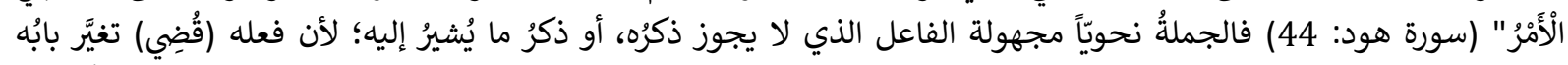

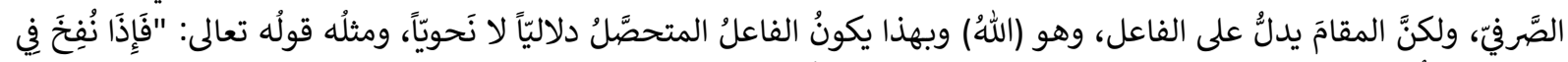

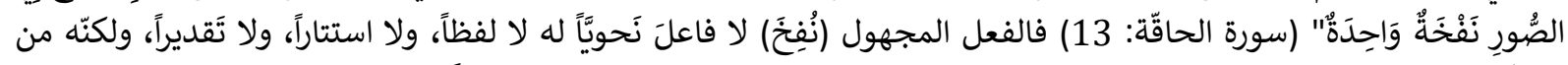

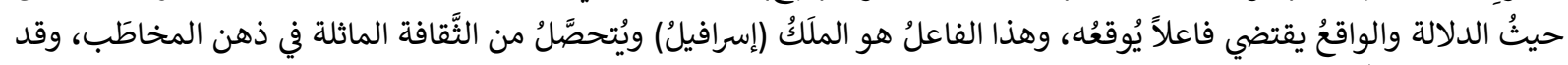

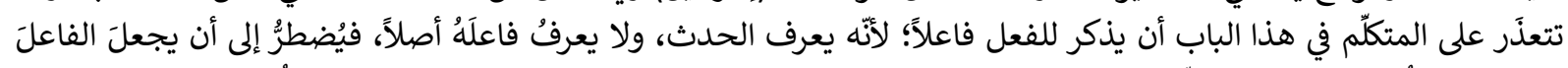

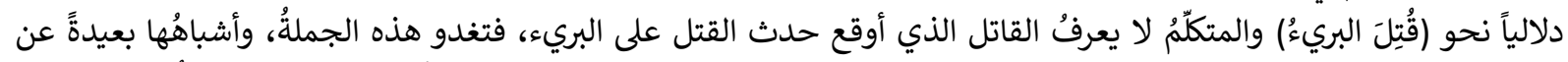

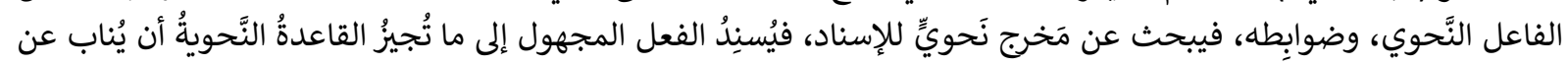
الفاعل.

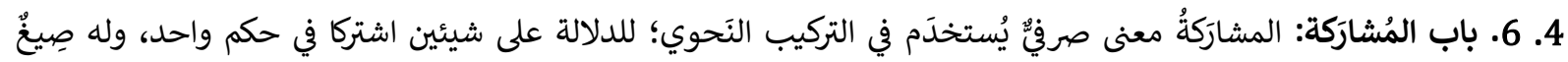

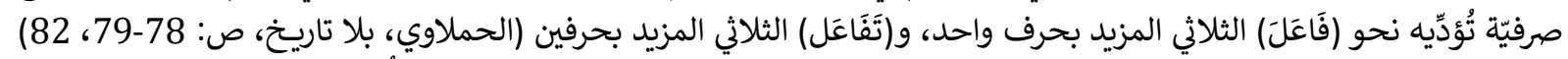

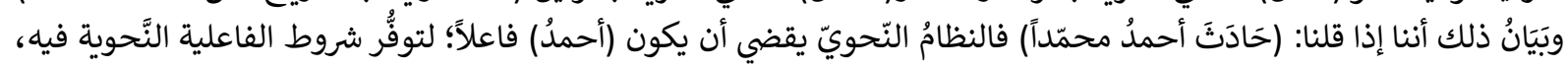

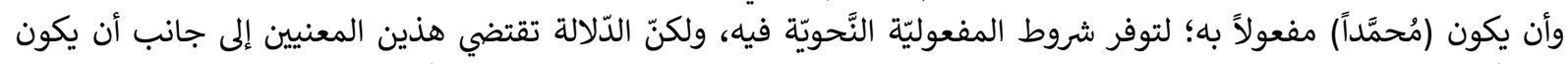

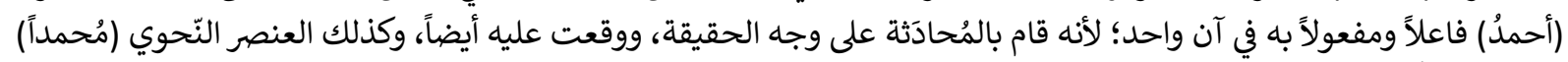

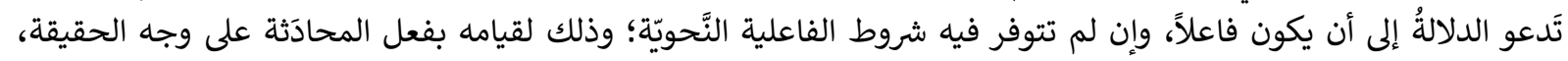

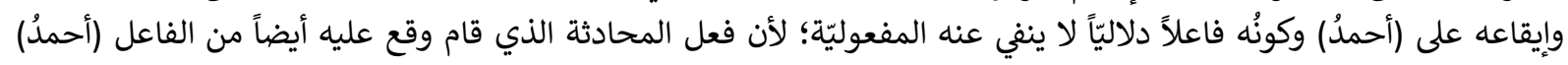

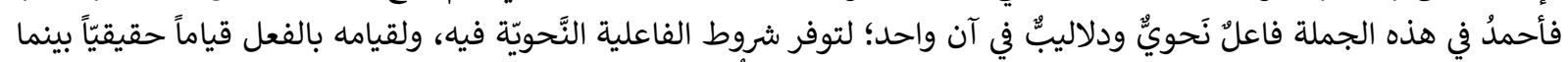

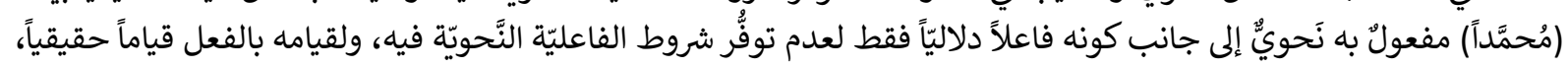

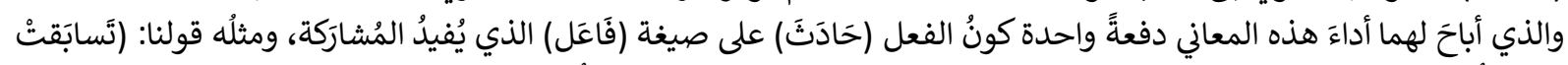

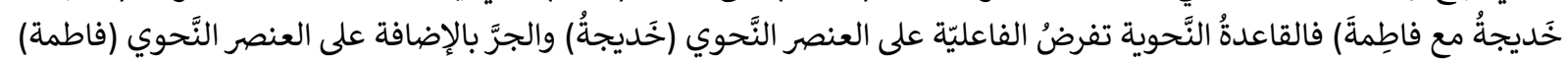




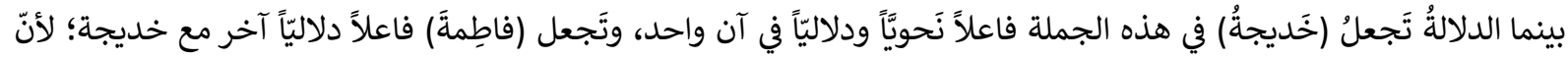

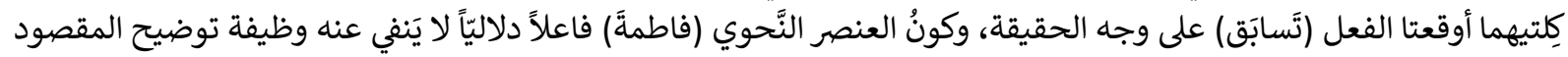

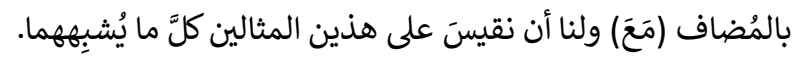

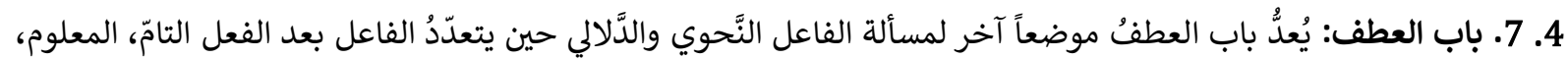

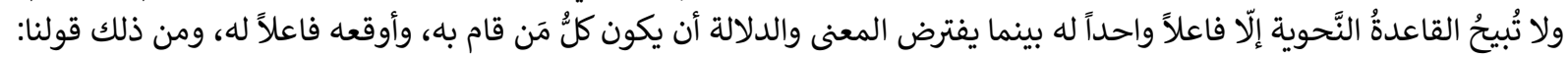

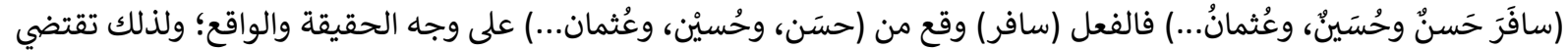

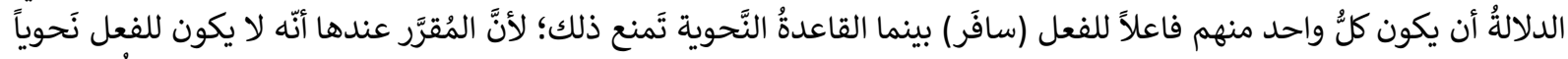

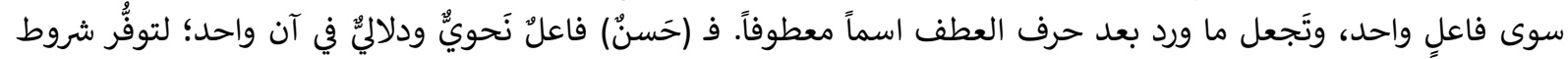

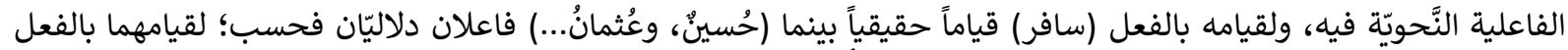

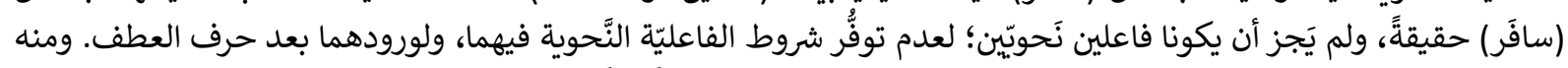

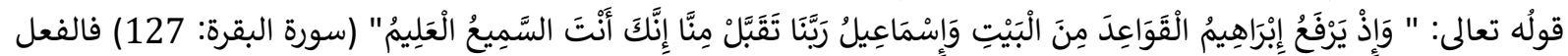

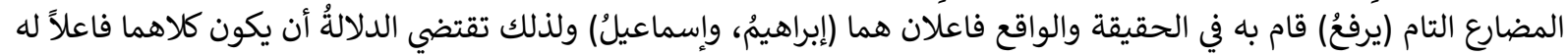

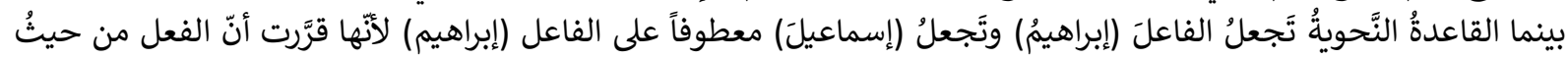

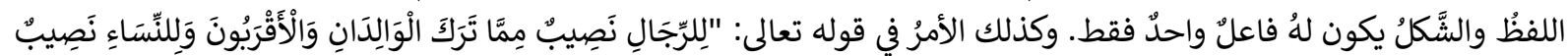

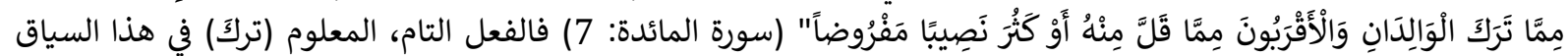

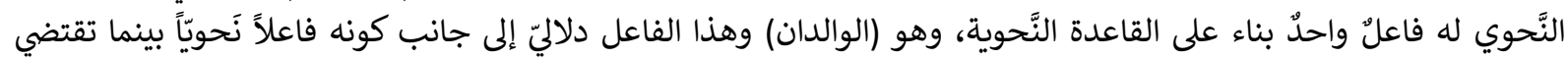

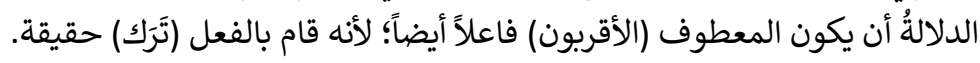

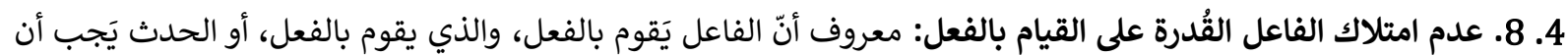

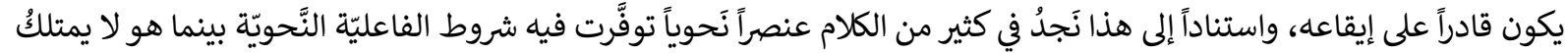

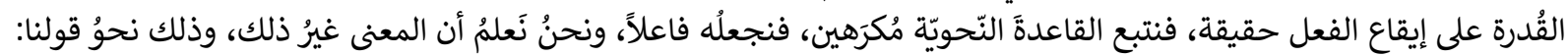

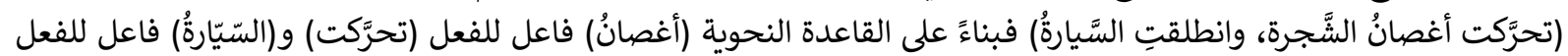

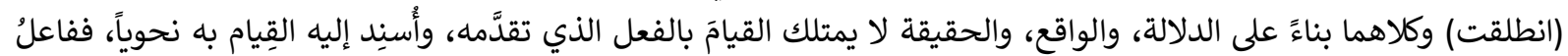

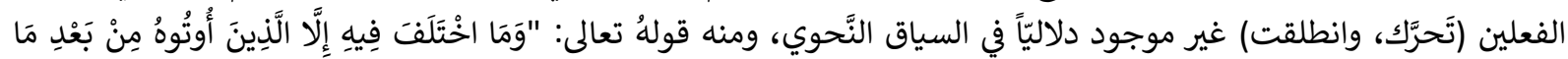

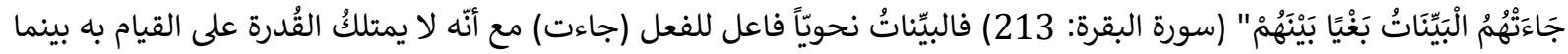

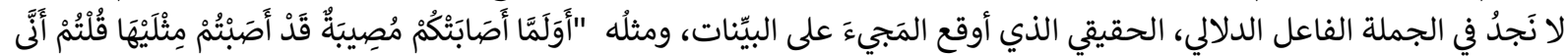

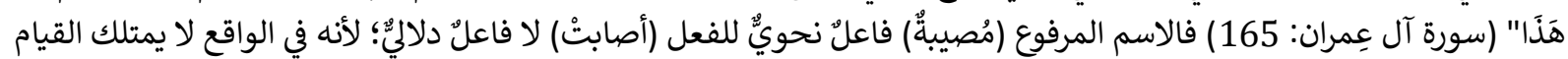

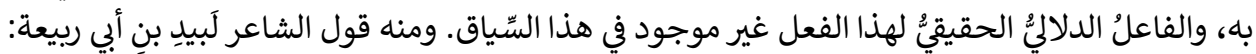

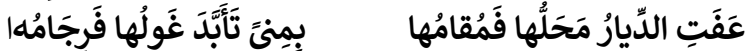

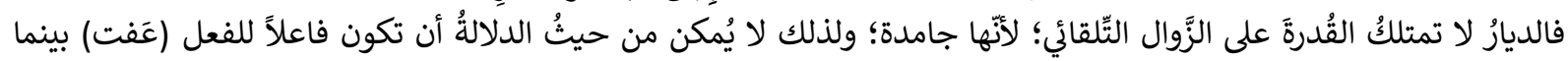
تَفرضُ القاعدةُ النَّحويّة عليه هذه الفاعليّة.

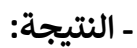

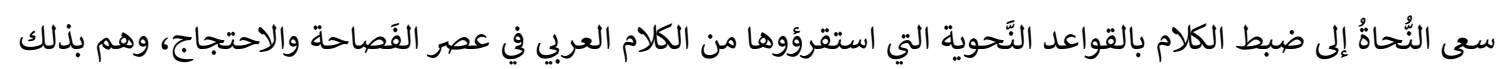

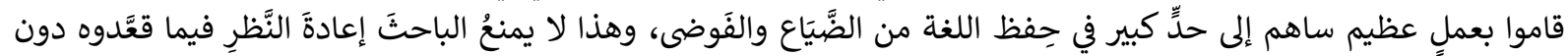

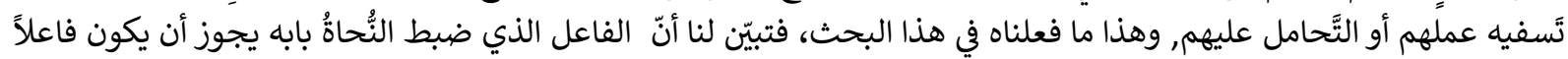

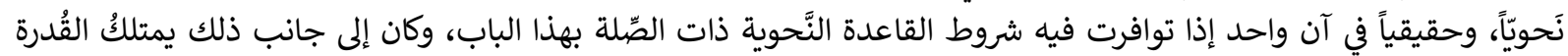

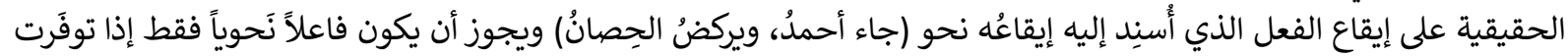

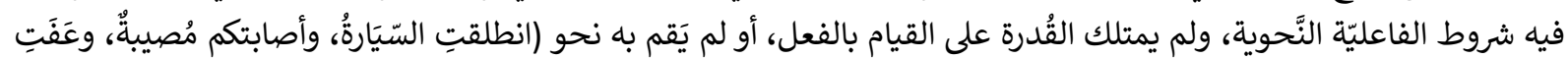

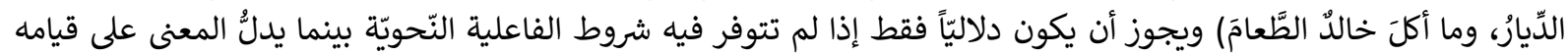

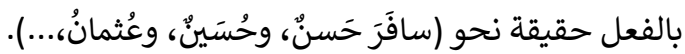

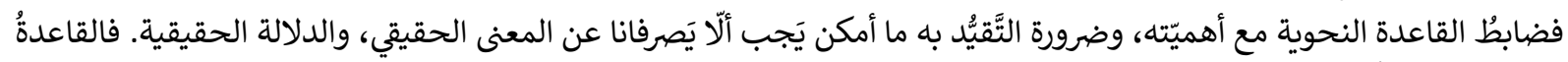

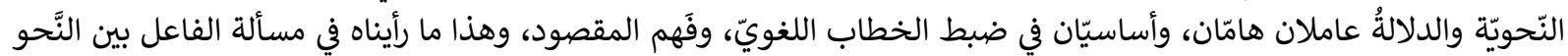

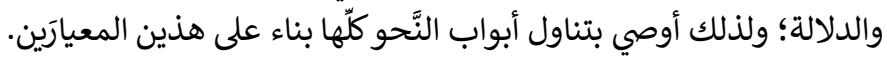




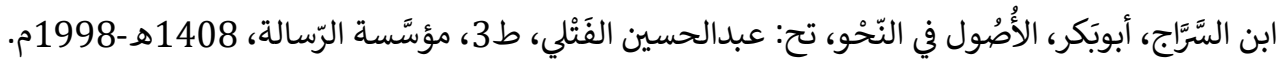

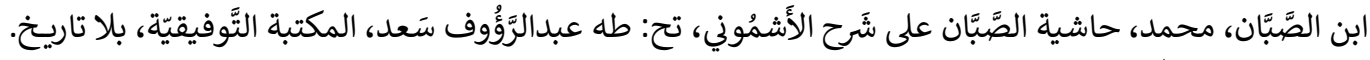

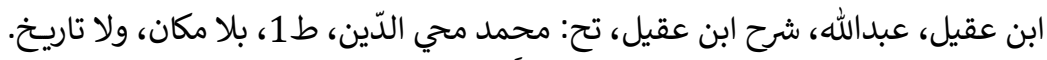

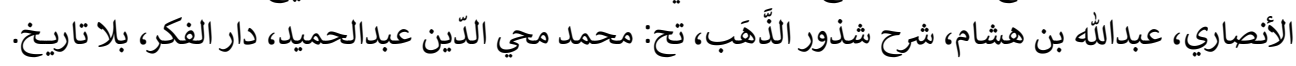

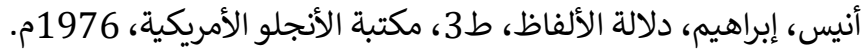

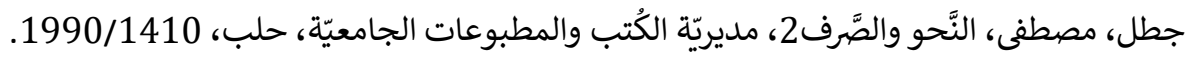

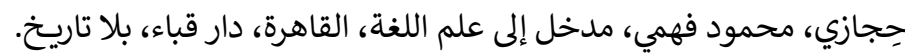

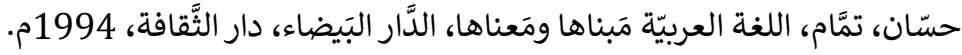

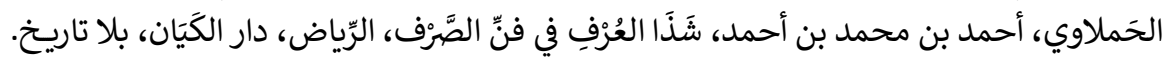

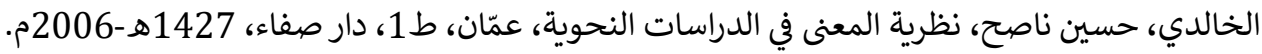

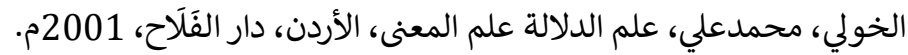

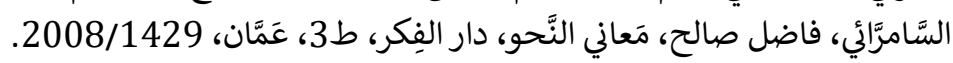

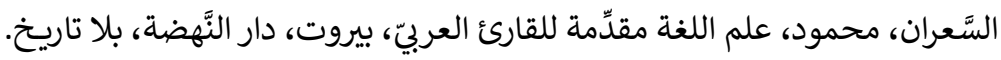

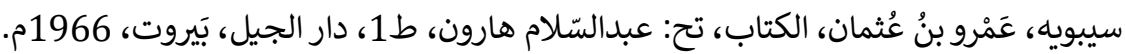

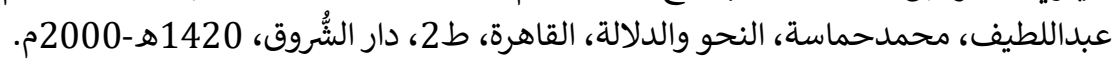

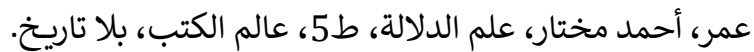

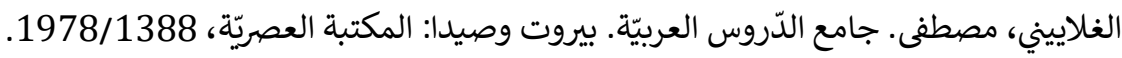

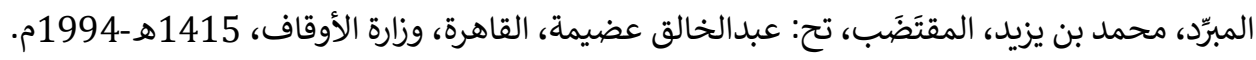

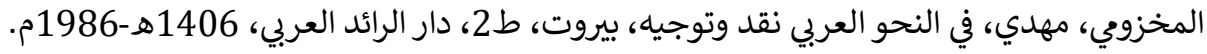


OVERVIEW OF CENSOR PHENOMENON IN MODERN ARABIC LITERATURE

Turgay GÖKGÖZ 


\title{
OVERVIEW OF CENSOR PHENOMENON IN MODERN ARABIC LITERATURE
}

\author{
Turgay GÖKGÖZ ${ }^{1}$
}

\begin{abstract}
:
Censorship is the state of publishing or not publishing or being open to use of books, newspapers, magazines, periodicals, radio and television, film or cinema, the internet, freedom of expression and all kinds of publications with the permission of a state-dependent control mechanism. The phenomenon of censorship has always been on the agenda of mankind throughout history from BC to the present. Through censorship, the control mechanism dominates what it deems objectionable about the state or society. Here, too, he considers the benefit of both society and the state. Censorship can show itself in the field of literature as well as in the field of media. Censorship has always existed from the most developed countries to the most backward countries. However, when we look at the countries where heavy censorship is applied, it is seen that these countries are not very advanced in terms of human rights. In the context of literature, censorship covers cultural elements such as a publication, book, magazine, theater or cinema. In Arabic literature, on the other hand, the phenomenon of censorship makes itself felt more in the field of novels. In this context, the novels of the most important writers were banned and the novels had to be published in other Arab countries when appropriate. When the subject was "forbidden", the related works inevitably attracted the attention of people and the works of some authors whose names were heard for the first time broke sales records and attracted a lot of attention. In addition, censorship is also encountered in the works of important names who have left their mark in the field of novels such as Naguib Mahfouz, Sunullâh İbrâhîm, Muhammad Shukri, Abdelrahman Munîf, Haidar Haidar and Layla Balabakki. In this study, it is aimed to give a general information about the effect of censorship and censored literary works in Arab countries.
\end{abstract}

Key words: Censorship, Arabic Literature, Novel

http://dx.doi.org/10.47832/ijhercongress2-9

${ }^{1}$ Kilis 7 Aralık University, Turkey, turgaygokgoz@kilis.edu.tr, https://orcid.org/0000-0002-9742-2722 


\title{
MODERN ARAP EDEBIYATINDA SANSÜR OLGUSUNA GENEL BİR BAKIŞ
}

\author{
Turgay GÖKGÖZ
}

\section{Öz:}

Sansür kitapların, gazetelerin, dergilerin, süreli yayınların, radyo ve televizyonun, filmin veya sinemanın, internetin, ifade özgürlüğünün ve her türlü yayının devlete bağlı olan bir denetim mekanizmasının izni ile yayımlanması veya yayımlanmaması veya kullanıma açılk olma durumudur. Milattan önceden itibaren tarih boyunca sansür olgusu her zaman insanoğlunun gündeminde olan bir durumdur. Sansür üzerinden denetim mekanizması devlete veya topluma dair sakıncalı gördügü şeyler üzerinde tahakküm kurar. Burada da hem toplumun hem de devletin faydasını gözetir. Sansür medya sahasında olduğu gibi edebiyat sahasında da kendisini gösterebilir. Dünyanın en gelişmiş ülkelerinden en geri kalmış ülkelerine kadar sansür her zaman varlığını göstermiştir. Ancak ağır sansürün uygulandığı ülkelere bakıldığında bu ülkelerin insan hakları açısından çok da ileri de olmayan ülkeler olduğu görülür. Edebiyat bağlamında sansür bir yayının, kitabın, derginin, tiyatro veya sinema gibi kültürel unsurları kapsamaktadır. Arap edebiyatında ise sansür olgusu daha çok roman sahasında kendisini hissettirir. Bu bağlamda en önemli edebiyatçıların romanları yasaklanmış ve romanlar yeri geldiğinde diğer Arap ülkelerinde yayımlanmak durumunda kalınmıştır. Konu "yasak" olunca ilgili eserler ister istemez insanların ilgisini çekmiş ve ilk kez adı duyulan kimi yazarların eserleri satış rekorları kırmış ve oldukça ilgi görmüştür. Ayrıca Necîb Mahfûz, Sunullâh İbrâhîm, Muhammed Şukrî, Abdurrahman Munîf, Haydar Haydar ve Leyla Ba'lebekkî gibi roman sahasında Arap edebiyatında iz bırakmış önemli isimlerin çalışmalarında da sansüre rastlanır. $\mathrm{Bu}$ çalışmada Arap ülkelerinde sansürün etkisine ve sansüre uğramış edebi çalışmalara dair genel bir bilgi vermek amaçlanmıştır.

Anahtar Kelimeler: Sansür, Arap Edebiyatı, Roman.

\section{Giriş}

Orta Doğu'da edebi eserlerin üretimi ve dağıtımıyla ilgili zorluklar, bölgenin genel siyasi ve sosyal ikliminden ayrı düşünülemez. Arap dünyasının karşı karşıya olduğu zorluklar, Birleşmiş Milletler Kalkınma Programı (UNDP) tarafından hazırlanan Arap İnsani Gelişme Raporu dizisinde özetlenmiștir. UNDP'nin temel teşhisi, Arap dünyasının siyasi haklar, kadın hakları ve bilgi gibi üç temel eksiklikten mustarip olduğuydu. UNDP raporlarına göre bu açlklar bölge genelinde insani gelişmenin önündeki engellerdir.

Bölgede edebi çalışmaların daha fazla yayılmasına engel teşkil eden üç kritik kaynak mevcuttur:

- Sansür

- Pazar

- Dağıtım zorlukları

Arap dünyasındaki özgürlük ve hakların yokluğu, edebi materyallere yönelik yaygın hükümet sansürünün siyasi bir iklimini yaratmaktadır. Edebi eserlere dair pazar, Orta Doğu'daki yoksulluk ve okuma yazma bilmeyenlerin yüksek oranları nedeniyle de sınırlıdır. Arap dünyasındaki kadınlar, sosyal ve ekonomik çevreden erkeklere göre daha fazla acı çekmektedir. Ne yazık ki bölgedeki kadınlar, dünyadaki en yüksek okuma yazma bilmeme oranlarından bazılarına ve çeşitli eğitim seviyelerinde en düşük kayıt oranlarına sahiptir. Bu ekonomik ve sosyal koşullar, edebi çalışmalar için dar bir pazara neden olur. Orta Doğu, dünyanın diğer bölgelerine kıyasla sınırlı bir bilgi altyapısına sahip olduğundan edebi eserlerin Arap toplumuna akabileceği kanalların az olması nedeniyle dağıtım nihai bir zorluktur (Schwartz, 2009: 3-7).

Sansür olgusu Orta Doğu'da önemli bir sorundur. Neredeyse tüm Arap Ortadoğu ülkeleri hükümetleri sansürü kullanır. Sansür genellikle siyasi, ahlaki veya dini açıdan hassas olduğu düşünülen veya rejimin çıkarlarına aykırı olan içeriğin yayımlanmasını veya dağıtımını durdurmayı amaçlar. Kahire'nin İslami ilim merkezi olan el-Ezher gibi dini kurumlar kitapların yasaklanmasını tavsiye ederek 
genellikle hükümete sansür noktasında yardımcı olur. İstihbarat servisleri de ulusal güvenlik tehdidi olarak addedilen içerikleri de yasaklar.

Bir kitabın basında önceden yer alması sansürü daha da hızlandırabilir. Selvâ en-Na îmî’nin Burhânu'l-'Asel adlı romanında durum böyleydi. Kitabın cinselliğe yönelik içeriğinin önceden tanıtımı nedeniyle çalışma gözden geçirilmeden birkaç Orta Doğu kitap fuarında yasaklandı.

Sansürün farklı uluslar tarafından çeşitli seviyelerde uygulandığı görülür. Bir körfez ülkesi olan Suudi Arabistan, rutin olarak sansür konusunda en muhafazakâr ülke olarak gösterilir. Örneğin, yayıncılar yakın zamanda 2008 Riyad Uluslararası Kitap Fuarı için devletin ilgili yetkililerine yayınlarını gönderdiler. esSâkî Kitapçılık adlı bir yayıncı kurum yaklaşık yüzde 90'ı hükümet tarafından sansürlenen 350 kitap sunmuştur. Bir diğer yayıncı olan Riyâdu'r-Rayyes ise 30 yasaklı kitap bildirdi. Yasaklı kitap örnekleri arasında Mısır sinema endüstrisini başlatan dört öncü kadının öyküsü olan Sultânâtu'ş-Şaşe: Râ'idetu'sSînema el-Mısriyye (Ekranın Kraliçeleri: Mısır Sinemasının Öncüleri) adlı eser sayılabilir. Suudi hükümeti, Filistinli şair Mahmûd Derviş'in eserlerini Suudi hükümetine yönelik kamuoyu eleştirileri nedeniyle de yasakladı. Benâtu'r-Riyâd (Riyad'ın Kızları) adlı eser de dört kadının samimi günlük hayatlarını anlattığı için yasaklandı.

Sansür, daha düșük derecelerde olsa da Mısır, Lübnan ve Ürdün gibi Arap ülkelerinde de mevcuttur. Mısır hükümeti genellikle sansürü uygular ve kitapların sakıncalı bölümlerini kaldırır ve belirli yayınların ithalatını yasaklar. Bu durum özellikle İslam'ı veya hükümeti eleştirdiği düşünülen kitaplar için geçerlidir. Kuveyt'te ise yetkililer 560 yeni kitabı inceledikten sonra 2007 Kuveyt Kitap Fuar'ında 230 kitabı yasaklamayı planladılar. Lübnan ise yayıncılık sahasında daha liberal yerlerden biri olarak kabul edilir ancak orada bile yayıncılar çalışmalarının gözden geçirilmesi için hükümetin Genel Güvenlik Genel Müdürlüğ̈̈ne göndermelidir. Nitekim mezhep gerilimlerini alevlendirebilecek çalışmaların daha fazla incelemeye tabi tutulduğu bildirilmektedir. Ürdün'de ise sansür esas olarak cinsellik ve Ürdün siyasi sistemine yönelik eleştirileri içeren dini unvanlarla ilgilidir (Schwartz, 2009 : 3-7). Yaygın sansüre rağmen, Orta Doğu'daki yazarlar bu zorluğun üstesinden gelmenin birçok yolunu bulmaktadır. Suudi Arabistan gibi kültürel olarak daha baskıcı ülkelerde yaşayan yazarlar, genellikle yurt dışında özellikle Lübnan veya Avrupa yayınevlerinde eserlerini yayımlamaktadırlar.

Sansür olgusu kimi zaman yazarları ve eserlerini ilgi odağı haline getirme kapasitesine sahiptir. Suudi yazar Turkî el-Ahmed'in el-'Addâme adlı romanı muhafazakâr krallıkta ayaklanma, cinsellik ve alkolün hikâyesini anlattığı söylenir. Bu eser Suudi Arabistan dâhil birçok ülke tarafından yasaklandı ve dört dini fetvanın hedefinde oldu. Kitabın bir ay içinde en çok satanlar listesine girdiği görüldü.

Yine de sansürün etkisi çoğu zaman boğucudur. Geniş bir kitleye ulaşmak ve onları etkilemek, nihayetinde birçok yazarın hedefidir ve sansür nedeniyle satışlar üzerindeki elde edilen şöhret, genellikle oluşan olumsuz etkinin üstesinden gelemez. Bu nedenle de diğer yazarlar, çalışmalarında otosansür uygularlar ve kitaplarının yasaklanmasından çekindikleri için yazacakları konuları sınırlandırırlar.

Kitap yasaklarından daha da kötüsü ise bazı yazarlar özgürlüklerine ve yaşamlarına yönelik açık tehditlerle karşı karşıya olduğu gerçeğidir. Arap diktatörlüklerini eleştiren Filistin kökenli Lübnanlı yazar olan Samir Kasir, 2005 yılında suikasta uğradı. Başka bir yazar ise Mısırlı Nevâl es-Saddâvî2, Arap toplumunu rahatsız eden birçok sosyal ve dini sorunu ortaya çıkaran yazılar yüzünden hayatından endişe duyarak ülkesi Mısır'ı terk etti. Ayrıca hapsedilen yazarların sayısı o kadar fazladır ki el-Cezire TV, görüşlerini yazdıkları için hapse atılan birçok yazarın hayatını ve çalışmalarını detaylandıran "Cezaevi Edebiyatı" adlı bir program yayımlamaktadır.

Sansür olgusu yayıncıları ve kitapçıları da olumsuz etkilemektedir. Örneğin Suudi Arabistan, Orta Doğu'daki kitapların en büyük pazarlarından birisidir. Suudi Arabistan'da hükümet sansürleri yayıncılar üzerinde büyük bir mâli yük oluşturduğu görülür. Kitap satış noktaları açısından Kuveyt'te bulunan Virgin Megastore, Ortadoğu'nun en büyük kitapçılarından birisiydi. Kuveyt hükümetinin kitaplardan birisindeki

\footnotetext{
${ }^{2}$ Hakkında detaylı bilgi için bkz.: Senem Soyer, "Mısırlı Nevâl es-Sa'dâvî ile Duygu Asena'nın Eserleri ve Edebi Kişiliklerinin Karşılaştırılması”", İstanbul Üniversitesi Sosyal Bilimler Enstitüsü Yayımlanmamış Doktora Tezi, İstanbul, 2016.
} 
tek bir paragraf nedeniyle ilgili kuruluşu üç haftalığına kapattı̆̆ bildirildi. Mağaza o zamandan beri perakende alanının yüzde 80'inini diğer işletmelere devretti (Schwartz, 2009: 3-7).

\section{Dışlanan Bir Edebiyat}

Siyasi, sosyal, dini veya cinsel nedenlerle dünyanın çeşitli yerlerinde reddedilen, kınanan, yasaklanan veya sansürlenen kitapların tarihi epeyce uzundur, Boccaccio'nun Decameron'u, Rabelais'in Gargantua ve Pantagruel'i, Rousseau'nun Les Confessions ve Baudelaire Les fleurs du mal veya Joyce'un Ulysses'i gibi (Nasalski, 2016: 17).

Her toplumun bütünlüğü ve kimliği için çok önemli olan bilgi süreçlerini düzenlemesi gerektiğinden, belirli sansür biçimlerinden arınmış hiçbir kültür yoktur. Modernitenin sağladığı gelişmelerinden geçen Batı'daki insanlar, eleştirel veya kışkırtıcı içeriğine rağmen tartışmalı edebiyata değer vermeyi öğrenirken Orta Doğu'daki bu kültürel deneyimleri paylaşmayan toplumlar hâlâ belirli türdeki edebi eserleri kabul etmekte sorun yaşamaktadırlar.

Arap ülkelerindeki çeşitli sansür biçimleri, romanlardan akademik makalelere, doktora tezlerine, konferans bildirilerine ve diğer ülkelerdeki makalelere kadar 650'den fazla farklı kitap ve makaleyi içerir (Nasalski, 2016: 17-18).

Bir zamanlar siyasi veya sosyal nedenlerle sansürlenen bazı yazarlar ve eserler, bugün okuyucuları arasında belirli bir popülerliğe sahiptir. Örneği; Mısırlı yazar Sunullâh İbrahim'in Tilke Râ'iha (O koku); Iraklı şair Abdulvehhâb el-Beyâti'nin çeşitli şiirleri ve Faslı yazar Driss Chraibi'nin Le passé simple (Geçmiş Zaman) adlı eseri zikredilebilir.

Ağırlıklı olarak dini temalarla ilgilenen veya çeşitli cinsellik biçimlerine göndermeler içeren diğer eserler sıradan insanlar ve entelektüeller tarafından kınanmakta ve reddedilmektedir. Bunlar arasında Cezayirli yazar Asiye Cebbâr'ın el-'Ataş (Susuzluk); Suriyeli yazar Haydar Haydar tarafından kaleme alınan Velîme li-A'şâbi'l-Bahr (Deniz Yosunlarının Ziyafeti) veya Mısırlı Alîfe Rif'at tarafından Ba'iden 'ani'l-Mi'zene (Minaraden Uzakta) gibi eserler yer alır. Birçok yabancı dile çevrilmesi ile önemli sanatsal ve sosyal başarılar olarak görülmesine rağmen bu eserler marjinal kalmaktadır (Nasalski, 2016: 18).

Suriyeli yazar Haydar Haydar'ın 1984 senesinde yayımlanan Velîme li-A'şâbi'l-Bahr (Deniz Yosunlarının Ziyafeti) adlı romanı da dikkat çeken kitaplar arasındadır. Haydar, ilgili kitabını 1970 senesinde profesör olarak geldiği Cezayir'de iken yazdı. Arap ve Mağrip dünyasında hem okunması hem de eleştiri açısından hissedilir bir varlık gösteren Deniz Yosunlarının Ziyafeti adlı bu romanın, şiir ve fantastik anlatıyı kullanarak roman 'düzeninde' bir devrim yarattığı söylenebilir. Yayımlanmasının üzerinden çeyrek asrı aşkın bir vakit geçtikten sonra etkisini hâlâ sürdürmesini nedeniyle Ezher şeyhleri ve bağlıları, Kahire'de gösteriler düzenleyerek bu kitabın yasaklanmasını ve yazarının da cezalandırılmasını talep etti (indyturk, 2021). Bu tür dışlanan bir edebiyatın en muazzam örneklerinden birisi de uluslararası bir üne sahip olan Faslı yazar Muhammed Şukrî (1935-2003)'nin eserleridir. Her şeyden önce yazarın olağanüstü bir şekilde kurgulanmış otobiyografisi olan el-Hubzu'l-Hâfî adlı romanı ön plana çıkar. Okuma yazma bilmeden büyüyen Muhammed Şûkrî ancak 20 yaşına geldiğinde okuma yazmayı öğrendi. Tanca'de fakirlikle büyümekle ilgili olan otobiyografisini kaleme aldı ve bu çalışma hayatta kalmak için yoksulluğa ve uyuşturucu kullanımına dair açıklamalarını içermekteydi. Kitap ilk olarak Paul Bowles tarafından 1973 senesinde İngilizceye çevrilerek yayımlandı (Nasalski, 2016: 18; vice, 2021).

Yakalanan başarıya rağmen Şukrî̀nin otobiyografisini ele alan eserin uzun seneler boyunca yayımlanması engellendi. Eserin ilk hali olan Arapça versiyonu ise Arap dünyasındaki birçok yayıncı tarafından reddedildi ve masraflarını yazarın kendisinin karşıladığı 1982 yılına dek basılmadı. Sonunda yayımlandıktan sonra bile Arapça versiyon başlangıçta cinsel içeriğin ve şiddet ile toplumsal gerçekliğin bir tasviri olarak algılanması nedeniyle sansürlendi. Ayrıca birçok eleştirmen tarafından edebi olmadığı düşünülerek reddedildi. Fas İçişleri Bakanlığı 1983-2000 yılları arasında ilgili kitabı yasakladı. Sansür, kitabın 2000 senesinde nihayet Fas'ta resmi olarak yayımlandığında sona erdi. Yine de kitap birçok Arap ülkesinde hâlâ yasaklı konumdadır. 2005 gibi yakın bir tarihte Şûkrî̀nin eseri, Kahire Amerikan Üniversitesi'ndeki bir müfredattan haiz olduğu müstehcen ifadeleri nedeniyle kaldırıldı ve sansür 2008 yılında Kahire Uluslararası Kitap Fuarı'ndan kitabın çekilmesine sebep oldu (Nasalski, 2016: 18; vice, 2021). 
Aslında el-Hubzu'l-Hâfí, 'sömürge' psikolojisine dair bir analizdir. Roman takibe alınmasına rağmen modern ve çağdaş Arap edebiyatında Mağrip anlatısını tesis eden ilk Mağrip romanıydı da. Nitekim eserin kaleme alınmasının üzerinden yarım asır geçmesine rağmen eser hâlâ düzenli ve beğenilerek okunmaktadır (indyturk, 2021).

Çoğu Batılı edebiyat araştırmacısı, romanı bazı dillere çevrilmiş olan önemli ve güçlü bir metin olarak algılar. Ünlü Amerikalı oyun yazarı Tennessee Williams, bunu "İnsan çaresizliğinin gerçek bir belgesi, etkisi paramparça" olarak tanımlar. Romanın gerçek değerini anlayan az sayıdaki Arap edebiyatçısından birisi ise ilgili romanı " 20 yaşında okur-yazar olmaya başlayan, alt sınıflardan okuma yazma bilmeyen Faslı bir çocuğun çok dokunaklı ve samimi bir hikâyesi" olarak nitelendiren Mısırlı bilgin Sâmiya Mahrez'di. "Yaşam tarihinin korkunç koşullarını büyüleyici bir metin haline getirebiliyor". Dikkat çekici bir şekilde bu sözler, 1998 yılında kitabı üniversite müfredatına dâhil eden Kahire Amerikan Üniversitesi'nden bir Profesörden geldi ancak kitap, müstehcen ve itici bulan öğrencilerden gelen birçok şikayetten sonra kitaptan yasaklandı (Nasalski, 2016: 19-20).

Mısırlı bir edebiyatçı olan Mecdî eş-Şafi'î’nin Mîtrû adlı çizgi romanı, eski Cumhurbaşkanı Hüsnü Mübarek döneminde birçok Mısırlı için günlük yaşamın bir parçası olan yozlaşmayı ve yoksulluğun sıradan insan üzerindeki kalıcı etkisini araştırmaktadır. Mısır hükümeti, 2008 yılında ilk çıktığında kitabı yasakladı: Hükümet güvenlik güçleri, kitabın "genel ahlaka aykırı" olduğunu iddia ederek yasakladı. 2013 yılında kitap nihayet Kahire'deki en az bir kitapçının raflarına geri dönmüştü. 2008 yılında yasaklandı ve tüm kopyalarına yetkililer tarafından el konuldu. Neyse ki yasak 2013'te kaldırıldı (vice, 2021).

Iraklı şair Nâzik Melâ'ike Kolera adlı şiirini yazmasının ardından serbest ve uyaklı şiire yönelik tepkiler bir türlü dinmedi. Yazıdaki bu içtihat bir aşırılık, mirasa saldırı, onu reddetme ve ona karşı bir devrim olarak düşünüldü. Bu nedenle de Arapçaya ve İslam'a karşı bir komploymuş gibi algılandı.

Suriyeli şair Nizâr Kabbânî'nin 1948 senesinde yayımlanan Tufûletu Nehd (Nehd'in Çocukluğu) adlı divanı, belki de Arap şiirini eşi görülmemiş bir yapısal cesarete taşıyan şiir kitabıdır. Şair bu kitapla bireysel özgürlüğe, bastırılan duyguların açığa çıkmasına ve erkek egemen bir toplumun kınanmasına dair ifadelere zemin hazırladı (indyturk, 2021).

\section{Mısır'da Sansür}

\subsection{Mısır'da değişmez bir gerçek: Sansür}

Aslında modern Mısır edebiyatını sansürden bağımsız düşünmek pek de doğru olmayabilir. Ülkede özellikle "dini eleştirmek" devrim sonrasında bile "tabu" durumundadır. Sansür sadece kitapların yasaklanması ile sınırlı kalmamakta aynı zamanda bir noktadan sonra Mısırlılar otosansür de uygulamaya başlamaktadır.

Mısır'da 1955 senesinden itibaren Sansür Kurulu'nun varlığı görülmektedir. Kurulun görevi, "Kamuoyuna tavsiye vermek ve kamuoyunu zararlı yayınlar hakkında bilgilendirmek, sanatçllar ve kamuoyu arasındaki ilişkinin güçlendirilmesine yardımcı olmak, toplumsal hassasiyetlere ters düşen yayınlar hakkında işlem yapmak" olarak ifade edilir. Sansür Kurulu kuruluşunun ardından binlerce kitaba sansür uygulamış durumda; kurul, yayıncıların kitapları basmasını engellemek için girişimlerde bulunur, hatta yazarlar ve kitapları hakkında dava da açar. Sansür Kurulu kitapların yanı sıra sinemadan görsel sanatlara dek birçok alandaki eserleri de hedef alır.

Kahire Amerika Üniversitesi tarih kürsüsünde Profesör olan Halîd Fehmî, el-Ehrâm gazetesinde yayımlanan bir yazısında bu durumu şu şekilde tanımlar: "Yaraya parmak basarcasına milli güvenliğimizi koruma sorumluluğunu kendisini küstahça Yayın Sansür Kurulu olarak tanımlayan sansür kurumundaki çalışanlara emanet ediyoruz. Bu kurum vasat ve bariz bir şekilde bilgiyle, bilimle ya da akademik araştırmayla ilgili cehaletini kanıtlıyor." (sabitfikir, 2021).

\subsection{Sansür sadece Mısırlllara değil!}

Pek çok ülke için sıradan bir durum hale gelmiş olan "yasaklı kitaplar", Mısır için de doğal bir durumdur. Öyle ki 1999 yılında "yasaklı kitaplar” silsilesi içerisinde Binbir Gece Masalları'nı sansürlemek de vardı. Neden olarak ise söz konusu kitabın "edepsiz ve ahlaka aykırı" bulunmasıydı. Nitekim Binbir Gece Masalları'nın Mısır'da şiddetli tartışmalara yol açması ilk kez görülen bir durum değildir. 1985 
senesinde bir grup, mahkeme kararıyla ilgili eseri piyasadan toplatmayı başarmıştı. Ne var ki bu karar bir yıl sonra daha yüksek bir mahkemenin kararıyla kaldırıldı. Son kararda ise Şehrazad'ın öyküleri "Arap ve İslam folklorunun en ünlü örneği" olarak yer almıştı. Aynı şekilde aralarında Nabokov'un Lolita'sı, Halîl Cibrân'ın Ermiş'i ve Selmân Ruşdî̀nin Şeytan Ayetleri'nin de bulunduğu birçok kitap Mısır'da uzun süre sansür kurulunun engeline takılan eserler arasındaydı (Green, Karolides, 2005: 163; sabitfikir, 2021).

Sansür kurulu haricinde Mısır'da dini bir otorite olarak görülen el-Ezher Üniversitesi'nin İslami Araştırma Konseyi de kimi zaman kitaplar hakkında yasaklatma girişimlerinde bulunur. Hâlid el-Berrî̀nin ed-Dunyâ Ecmel mine'l-Cenne (Hayat Cennetten Güzel) adlı romanı bu konsey tarafından yasaklandı. Aynı şekilde Tâhâ Huseyn'in el-Eyyâm (Günler) adlı kitabı da öyledir. Mısır Uluslararası Kitap Fuarı'na katılan eserler de bazen sansüre maruz kalabilmektedir. Lübnanlı yazar Hanân eş-Şeyh ve İlyâs Hûrî de bu isimler arasındadır (sabitfikir, 2021).

Enver Sedat dönemi baskıları sırasında tüm dünyada yükselmekte olan feminist edebiyat, Mısır’ı da etkiledi. Bu akımın öncüsü Nevâl es-Sa'davî'dir. Aynı zamanda Selvâ Bekr, Bâbu'l-Meftûh (Açık Kapı) romanı ile bilinen Latîfe Zeyyât da baskılara, sansürlere ve kitaplarının yasaklanmasına rağmen feminist yazında eserler verdiler. Erkek egemen bir toplumda kadın olmanın zorluklarını eserlerinde anlatan esSa'dâvî, bu nedenle birçok kez tehdit edildi ve baskıya uğradı.

Daha çok Adonis mahlasıyla tanınan Ali Ahmed Said Eşber, en tartışmalı ve etkili Arap şairlerinden biri olarak kabul edilir. Şiirleri ağırlıklı olarak İslam'ın gelenek ve değerlerini eleştirir. 2013 yılında kitapları Cezayir ve diğer birçok Arap ülkesinde yakıldı. Şairin kendisi Arap Dünyasında yaşayan en büyük şairlerden biri olmaya devam etmektedir (stepfeed, 2021).

Devrimden sonra yazarlar, yönetmenler ve oyun yazarları sansüre karşı daha güçlü bir duruş sergilese de sansür hâlâ varlığını sürdürmektedir. Sansür sadece basım yasakları üzerinden değil işten çıkarmalar aracılığıyla da devam etmektedir. Mısır'ın en önemli edebiyat dergisi olan Ahbâru'l-Edeb'in bazı editörleri, yazı işleri müdürü Mecdî 'Afîfî tarafından derginin bağımsızlığını tehlikeye attıkları nedeniyle işten çıkarıldı. Sansür Kurulu, Ramazan Ayı'nda yayımlanan yayınları bile incelemektedir. Açıkçası edebiyat ve sansür bağlamında Mısır'ın önünde kat etmesi gereken çok daha uzun bir yol olduğu görülmektedir (sabitfikir, 2021).

$\mathrm{Bu}$ gerçeklikten hareketle XX. yüzyıl büyük bir kültür ve düşünce tartışmasına tanıklık etti. Bu tartışmanın sebebi, Kâsım Emîn'in 1899 senesinde yayımlanan Tahrîru'l-Mer'e (Kadının Özgürleşmesi) adlı kitabıydı. Söz konusu kitabın çıktığı yıl doğan Tunuslu yazar Tâhir Haddâd (1899-1935)'ın Şeriat ve Toplumda Kadınımız adlı kitabı da bu kategoridedir. Tâhir Haddâd'ın kitabı kadının konumunu yükseltme, medeni ve siyasi haklarını savunma konusunda Mağrip'in entelektüel çabasına dair bir portre sunar. Belki de Tunus, Tâhir Haddâd'dan sonra kadın ve erkek arasındaki eşitlik meselesinin ortaya atılmasında öncülük etmiştir. Bu öncülüğün en son örneği ise Tunus'un 2018 senesinde kabul ettiği mirasta eşitlik yasası ve Tunuslu Müslüman kadının gayrimüslim birisi ile evlenme hakkıdır. Tunus'taki kimi kesim, Tâhir Haddâd'ı kafir ve dinsiz olmakla suçladı. Yazar akademik çevreden uzaklaştırıldı ve çalışmaktan men edildi. Ancak Tâhir Haddâd, karşı karşıya kaldığı bu tecritten ötürü çektiği sıkıntılara rağmen düşüncesinden geri adım atmadı. Hatta bu tartışmanın ardından Zeytune Eğitim Reformu hakkında bir kitap bile kaleme aldı (indyturk, 2021).

\subsection{Felsefi Düşünce Alanı}

Edebiyat ve eleștiri sahasında ise Mısırlı eleştirmen Tâhâ Huseyn, 1926 senesinde yayımlanan Cahiliye Şiiri Üzerine adlı kitabında, 'kutsal' düşüncesini eleștiriye tabi tutarak her şeyi daimî olarak sorgulanabilir hale getirmeye çalıştı. Kitap, geleneksel Arap seçkininin boğulduğu düşünce bozukluğuna değindi. Bu kitap da aynı șekilde büyük bir tartışma ile yüzlești. Her açıdan kitaba yönelik olarak bir savaş başlatıldı. Bazıları yazarın idam edilmesini ve üniversiteden kovulmasını isterken bazıları da hapsedilmesi için uğraştı. Yazarın kitapları toplatıldı, kendisinden kültürel birikime ve dine değinen bazı bölümleri de silmesi istendi. Tâhâ Huseyn yargılandı ve bazı bölümleri silerek kitabı Cahiliye Edebiyatı adı ile yeniden yayımladı.

Luis 'Avad (1915-1990)'ın 1980 senesinde yayımlanan Arap Dilini Kavramaya Giriş adlı kitabı da ses getiren, hem uzman hem de okuyucu nezdinde XX. yüzyıla damgasını vuran kitaplardan birisidir. Bu 
kitap Arapçanın tarihini modern ve aynı zamanda cesur bir bakış açısıyla tartışmaya açan önemli bir eserdir. Zira Arapçanın diğer dillerle olan ilişkisi üzerinde durur. Arapçanın kendisinin bizzat bir 'mucize' olduğunu düşünen bu akımın bağlıları aslında Kur'an'ın mucizeliği düşüncesini Kur'an'ın haiz olduğu dile indirgerler. Kitabın başlı̆ı̆ndan da anlaşıldığı üzere gibi kitap sadece dilbilimsel bir çalışma değil aynı zamanda fikri, medeni ve tarihi bir ansiklopedidir de. Bu kitapta ortaya koyulan düşünce cesaretten dayanak alır ve Arap ile İslam tarihinde sessiz kalınmanın tercih edildiği şeyler üzerinde durur. Kitap, Ezher'deki selefi akımın yönettiği üniversitede de büyük bir gürültü kopardı ve bu durum mahkeme ve kitabın toplatılması ile sonuçlandı. Belki de Luis 'Avad'ın Arap Dilini Kavramaya Giriş kitabı hak ettiği değerde okunmadı. Halbuki o, zamanın kitabıydı (indyturk, 2021).

\subsection{Yakupyan Apartmanı Romanı}

'Alâ' el-Asvânî Mısırlı bir yazar, diş hekimi ve aktivistir. Kendisine ait olan 'İmâratu Ya'kûbyân (Yakupyan Apartmanı) adlı eser, Arap dünyasında beş yıl üst üste en çok satan ve 30'dan fazla dile çevrilen eserlerden birisi olmuştur. Kitabın İngilizce baskısı olan Yacoubian Building bile 75.000 kopya ile satılmıştır. Yakupyan Apartmanı daha sonra bir televizyon filmi ile daha fazla kitleye ulaşmıştır. İlgili roman 2011 senesinde de Nobel Edebiyat Ödülleri adayları arasında gösterilmiştir.

Edebiyatçı olmasının yanı sıra diş hekimi de olan 'Alâ' el-Asvânî'nin kaleme aldığı Yakupyan Apartmanı, yazarın ilk muayenehanesinin olduğu bir apartmandır. Toplumsal gerçekçi olan bu eser, bir apartmanda yaşayan karakterler ve yaşanılan olayların bir ülkenin yansıması gibi olduğu için apartman romanın merkezine yerleştirilmiştir. Bu eser çağdaş Mısır toplumunu tasvir edilmiş ve İngilizce, Çince, Fransızca, İtalyanca, Danca, Rumence, İspanyolca, Yunanca, Fince, Çekçe, Portekizce, Felemenkçe, Norveççe, Slovakça, Katalanca, Malayca, Hırvatça, Boşnakça, Sırpça, Bulgarca ve Endonezce gibi dillere çevrilmiştir.

Yakupyan Apartmanı'nın Mısır toplumundaki tabulara ve yönetimdeki bozulmaya dikkat çeken en önemli eserlerden birisi olduğu görülür. Önde gelen birçok entelektüel, bu eserin Mısır halkındaki devrimci duyguları harekete geçirdiğini düşünmüştür. Yakupyan Apartmanı'nda birbirinden farklı karakterlerin varlığı Mısır toplumunun ne denli karma bir yapıya sahip olduğunu göstermenin yanı sıra cinselliği ön planda tuttuğu ve devrimci duyguları tetiklediği gerekçesiyle bir süreliğine yasaklanmış eserlerden birisi olmuştur (Bakır Dayı, 2021: 158-159).

\subsection{Mahfûz'un Cebelavi Sokağı Çocukları}

el-Evladu'l-Harâtinâ (Cebelavi Sokağı Çocukları) ilk olarak 1959 senesinde el-Ehrâm gazetesinde tefrika halinde yayımlandı. Roman haiz olduğu içerik nedeniyle özellikle de dini otoritelerin muhalefetlerini üzerine çekti ve eserin Mısır'da yayımlanması derhal yasaklandı ve neredeyse 50 yıl süreyle yasaklı halde kaldı (vice, 2021). Daha sonraları 1967 yılında Lübnan'da basılmıştır. Mahfûz, kitabında üç tek tanrılı İbrahimî dinlerinin iç içe geçmiş tarihini bir hikâye şeklinde vurgular. Mahfûz, Nobel Ödülü'ne aday gösterildiğginde kitap yeniden ilgi gördü. 1988'de Nobel Edebiyat Ödülü'nü kazanan Mahfûz, altı yıl sonra bir saldırıya uğrayacaktı (stepfeed, 2021).

Necîb Mahfûz'un Cebelavi Sokağı Çocukları romanı edebiyatta sansürün ve daha da ötesinde edebiyatçıları hedef göstermenin bir başlangıç noktası oldu. Cebelavi Sokağı Çocukları'nda yaşayan insanların hikâyesi üzerinden, Adem ve Havva'dan başlayarak dini tarihe yer veren bu roman özellikle de İslamcı kesimin tepkisini çekti. Mahfûz'un romanı ve dini eleştirmesi o kadar tepki gördü ki Ömer Abdurrahman, "Mahfûz bu kitabı yazmasaydı, Selmân Ruşdî Şeytan Ayetleri'ni yazacak gücü bulamazdı" yorumunda bulundu. Bu olayın ardından Mahfûz, 1994 senesinde sağ kolunun felç olmasına sebep olan bir suikasta uğradı (sabitfikir, 2021).

Mahfûz, 1988 yılında Nobel Ödülü'nü kazandı. Cebelavi Sokağı Çocukları'nı yazdığı için onu asla affetmeyen radikaller ödülün, kitabı yasaklılar listesinden çıkarmak için bir bahane olarak kullanılacağından korkarak saldırılarını yenilediler. Mahfûz, 1989'da verdiği bir röportajda, "Roman aslında 30 yıllık bir süre boyunca unutulmuştu" dedi, ancak ödülün ardından İslamcı odaklı tüm gazete ve dergilerde çok ağır saldırılara maruz kaldı. Dolayısıyla burada yayımlama fikri tartışılacak bir konu bile değildir. Mısır cumhurbaşkanı Hüsnü Mübarek'in romanın yayımlanması gerektiğine dair açılklaması ve Arap dünyasının geri kalanının çoğunda kullanılabilirliği göz önüne alındığında kitap üzerindeki yasağın 
kaldırılması için yeni girişimlerde bulunuldu. Ancak Mısır'ın aylık el-Yasar Dergisi 1989 yılında bunu serileştirmeye başladığında İslami basın buna karşı o kadar şiddetli bir kampanya yürüttü ki Mahfûz'un kendisi dergiden serileștirmeyi durdurmasını istedi (Karolides, Bald, Sova, 2011: 206-207).

Mahfûz'un yaralanmasının ardından konuşan hükümetin Enformasyon Bakanı, hükümetin yazarın hiçbir çalışmasını yasaklanmasının desteklemediğini söyledi. Açıklaması, Cebelavi Sokağı Çocukları'nın resmi yasağının sona erdiği şeklinde yorumlandı. Mısır gazeteleri romanı seri hale getirmek için acele ederken, Mahfûz daha sonra yayımlanmasını istedi. "Mesele, dikkatleri hayatıma karşı işlenen bir suçtan bu romanın dine karşı olup olmadığına çevirmek" dedi. Ancak talebi dikkate alınmadı. Saldırıdan birkaç hafta sonra, roman 35 yıl sonra ilk kez Mısır basınında yayımlandı ancak Mısır'da bir kitap halinde yayımlanması resmen yasaklandı. Yasağa rağmen kitabın Lübnan baskısı yasal olmayarak satılmaya devam etmişti ve romanın İngilizce çevirisi de zaten mevcuttu. Mahfûz, Ağustos 2006'da 94 yaşındayken hayata veda etti. Dört ay sonra kitap Mısır'da resmi bir şekilde Arapça olarak yayımlandı ve Mısır'da en çok satanlar arasına girdi (Karolides, Bald, Sova, 2011: 206-207).

Modern Mısır edebiyatının bir sonraki nesli ise Nobel Ödülü'ne de aday gösterilen Yusuf İdris'in öne çıktığı "60'lar kuşağı" idi. 1952 darbesinden sonra ortaya çıkan ve Arap sosyalizmini destekleyen bu edebiyat akımı çerçevesinde yayımlanan eserler, 1967 İsrail yenilgisi ve Nasır rejiminin sonra ermesiyle birlikte Ortadoğu'nun içinde bulunduğu "Nekse" - yani bir nevi durgunluk - dönemini ve bu süreçte Arap toplumlarının kapitalistleşmesini sert bir şekilde eleştirdiler. Necîb Mahfûz'un sakat kalmasına neden olan tahammülsüzlük, bu dönemde ise "sansür" olarak kendisini gösterdi. Necîb Mahfûz'un manevi oğlu olarak anılan ve tarihi kitaplarında aslında bugünü alegorik bir şekilde anlatan Cemâl el-Ğitânî3, kitapları yüzünden ciddi baskılarla karşılaştı ve Zeyni Berekat adlı romanını Şam'da yayımladı. Bir diğer Mısırlı edebiyatçı olan Yûsuf el-Kâ'id'in ise el-Harb fî Berri Mısr (Mısır Topraklarında Savaş) adlı romanı Mısır'da on yıl boyunca yasaklandı. Ne yazık ki birçok edebiyatçı baskılara dayanamayarak Suriye ve Lübnan'a göç etti (sabitfikir, 2021).

\section{Suudi Arabistan ve Irak'ta Sansür}

Abdurrahman el-Munîfin4 romanlarında petrol ve siyasi çıkarların, insan özgürlügü ve Suudi Arabistan'ın üzerindeki etkilerini tartışırken, Recâ' es-Sâni'nin romanı toplumda kadın haklarını ele alır. Benâtu'r-Riyâd (Riyad'ın Kızları) 2005 yılında Recâ' Abdullah es-Sâni' adlı genç bir Suudi kadın yazar tarafından kaleme alınmıştır. Riyâd'ın Kızları, Suudi Arabistan'daki dört üst sınıf genç kadının hikâyesini anlatır. Hikâye çoğunlukla katı ve baskıcı Suudi toplumu içinde gerçek aşkı bulma ve romantik ilişkileri sürdürme mücadelelerine odaklanır. Roman aynı zamanda dört kadının Suudi Arabistan'daki hayatlarını anlamalarına ve yönlendirmelerine yardımcı olurken paylaştıkları yakın dostluğun iniş çıkışlarını da içerir.

İlgili roman doğası gereği Suudi toplumunda kutuplaştırıcı bir kitaptı. Roman, dört Suudi kız arkadaşın farklı hikâyelerinden ve her birinin ailesindeki erkek egemenliğinden nasıl mustarip olduğunu anlatır. Aynı zamanda Suudi halkının Batı hakkında sahip olduğu bazı klişeleri de ortaya koymaktadır. Roman, Suudi Arabistan'da yasaklandı ve bazı radikaller yazarın alenen özür dilemesini talep etti. Yazarlar, gazeteciler ve eleştirmenlerden derlenen çeşitli görüşlere göre roman, teokratik toplumun gerçekliğini ortaya çıkardığı ve gereksiz muhafazakârlık idolünü yıktığı için bir başyapıttır (Yehia, 2014: 17; Karolides, Bald, Sova, 2011: 53-55).

Riyâd'ın Kızları'nın daha derin bir analizi, eleştirilerin çoğunun romanı sansürlemenin gerçek nedenlerini ele almadığını ortaya koymaktadır. Bir başka neden de yazarın genç bir kadın olması olabilir ki bu durum kadınların rolü çok kısıtlı olduğu için Suudi hükümeti için muazzam bir meydan okumayı

\footnotetext{
${ }^{3}$ Hakkında detaylı bilgi için bkz., Hamdi Sakkut The Arabic Novel (Bibliography and Critical Introduction 1865- 1995), The American University in Cairo Press, New York, 2000, p. 48-50.

${ }^{4}$ Hakkında detaylı bilgi için bkz., İlknur Emekli, "Abdurrahman Munif Hayatı, Edebi Kişiliği, Eserleri ve enNihâyât Adlı Romanının İncelenmesi”, Atatürk Üniversitesi Sosyal Bilimler Enstitütüsü Yayımlanmamış Yüksek Lisans Tezi, Erzurum, 2006.
} 
temsil etmektedir. Suudi kadınlara uygulanan kısıtlamalar farklı açılardan temsil edilmekte ve İnsan Hakları İzleme Örgütü tarafından 2003 yılı raporunda belgelenmektedir (Yehia, 2014: 18).

Irak'ta dini kitaplara ek olarak George Orwell'in Hayvan Çiftliği (1944) ve 1984 (1948) gibi edebi kitaplar da yasaklandı. Bir kitabı ünlü yapmanın en iyi yolunun onu sansürlemek olduğu iyi bilinir. Her iki kitap da Irak gerçekliğini farklı şekillerde yansıtır. Bununla birlikte, her ikisi de Saddam Hüseyin rejimi altındaki Irak'taki edebiyatın statüsüyle güçlü bir şekilde bağlantılıdır. Hayvan Çiftliği adlı roman, birkaç kopya dışında Irak'ta yaklaşık kırk yıl boyunca sansürlendi. Sovyetler Birliği dağıldıktan sonra ilk kez izin verildi. Çünkü kitabın köklü itibarı Irak hükümetini izin vermeye zorladı.

Orwell'in Irak'taki ikinci sansürlü kitabının adı 1984'tür ve 1948 yılında basılmıştır. Hayvan Çiftliği hayvanlarla ilgilenirken yazarın 1984 adlı romanı ise insanlarla ilgilenir. Orwell, bu romanda otoriter hükümetleri yalanlarını açı̆̆a çıkararak ve onlarla ilişkili belirli bir özelliği, yani zafer kompleksini aydınlatarak açıkça eleștirir (Yehia, 2014: 24, 41, 47).

Iraklı yazar Fu'âd et-Tekerlî, Irak toplumunda yasaklanmış birçok konudan ikisini ele almaya karar verdi. Çünkü edebi metinlerin dilden değil, aslında kültürden oluştuğu fark edilmeye başlandı. Zira dil kültürün aracıydı. et-Tekerlî’nin çalışması Irak'ta bulunan sorunların yeniden sunumudur. Yazar, belirli tabu konuları seçmiş ve bunları bir anlatı çerçevesinde yeniden yaratmıştır. Fu'âd et-Tekerlînnin hikâyelerine gelince kültür, Iraklıların bir romanı kabul etme veya reddetme konusunda belirleyici faktör olduğunu düşünme biçimini şekillendirmede rol oynamıştır (Yehia, 2014: 50).

Hindistan doğumlu İngiliz yazar Selmân Ruşdî’nin Şeytan Ayetleri, 26 Eylül 1988 tarihinde Viking Penguin yayınevi tarafından İngiltere'de yayımlandı. İlgili eser Ruşdînnin dördüncü romanıydı. İlki fark edilmedi, ancak ikincisi, Geceyarısı Çocukları, 1981'de prestijli Booker Ödülü'nü kazandı ve Ruşdî'yi İngiltere'nin en saygın yazarlarının genç nesli arasına yerleştirdi. Şeytan Ayetleri İslam'ın kuruluşu, Thatcherizm döneminde İngiltere, Asya göçmen topluluğu ve çeşitli müttefik kaygllarla ilgilenir. Pek çok eleştirmen kitabı anlaşılmaz bulduğunu kabul etti ve onu Ruşdî’nin şimdiye kadar kaleme aldığı en iyi eser olarak övdü. Kitaba yapılan ilk saldırılar, onun İngiltere'de yayımlanmasından önceydi. Eylül ayının başlarında iki Hint dergisi yazarla yaptıkları röportajlarını yayımladı. Bu parçaların içeriği, bir Hint muhalefet milletvekili olan Syed Shahabuddin'in kitabın Hindistan'da yasaklanması için bir kampanya başlatmasına yol açtı. 1988'in sonunda Hindistan, Pakistan, Suudi Arabistan, Mısır, Somali, Sudan, Malezya, Katar, Endonezya ve Güney Afrika gibi ülkeler ilgili esere dair tüm yayınları yasaklamıştı (Green, Karolides, 2005: 492).

\section{Bir Kadın Yazar Olarak Ba'lebekkî}

Leylâ 'Alî el-Hâcc Ba'lebekkî, 1934 senesinde Beyrut'ta Dâru'l-Mreisse'de Şii bir ailede doğdu. Yazar bir röportajında kendisiyle ilgili olarak şu ifadelere yer verir: “Ba'lebek'ten Lübnan'ın güneyine göç eden Şii olan bir ailede doğdum. Ailesi daha sonraları Beyrut'ta yaşamak ve çalışmak için göç etti. Çiftçiliğe ek olarak büyük dedem, köyün çocuklarına ve gençlerine zeytin ağaçlarının gölgesinde eğitim verdi. Fakir bir adamdı ve din konusunda da iyi bir bilgeydi. Babam zecel türü halk şiirleri yazdı ama annem okuma yazma bilmiyordu ve durumu benim öfkemi alevlendirdi. On dört yaşındayken yazmaya başladım." (Fettahoğlu, 2018: 421).

Yazar dini ve mezhepsel nitelikli siyasi partilere karşı çıktı. Din ve devlet arasındaki işlerin ayrılması gerektiğine inanan birisiydi. Yazar, Ene Ahyâ'nın ilk çalışmalarını parlamentodaki işi sırasında yazmıştır. Kendisi âdeta ilgili romanda yer alan Lînâ karakteri gibi gündüz çalışmakta, gece üniversite eğitimine devam etmekteydi.

Açıkçası yazılarını yazmaya henüz on dört yaşında en-Nehâr (Gündüz) gazetesinde başlayan yazar, ilk zamanlar tepki çekmemek adına takma isim kullandı. 1957-1958 döneminde ayda bir defa "Özgürlük Fikirleri” başlığı altında Savtu'l-Mer'e (Kadınların Sesi) Dergisi'nde yazdı. el-Havâdîs (Haberler), edDustûr (Anayasa), el-Usbû' (Haftalar) ve el-'Arabî (Arap) isimli gazetelerde de yazıları mevcuttur. Savtu'lMer'e'nin Beyrut Amerikan Üniversitesi'nde Arap Edebiyatı bölümünde yüksek lisans yapan bayan editörü Advîk Şaybûb, Ba'lebekkî'yi etkilemiş, onu yazmaya teşvik etmiş ve yeni bir yetenek olarak görmüştür. Onun ısrarı yazarın yazmanın ve yayımlamanın önemini anlamasını sağlamıştır. 
Advîk Şaybûb, Ba'lebekkî'nin romanı olan Ene Ahyâ'nın el yazması nüshasını okuyan ilk kişiydi. Beyrut'taki yayıncılar romanı yayımlamayı istemediler. Bunun üzerine Şaybûb, yeni çıkan bir yazarı desteklemek için bir bildiri yayımladı. Bu bildiriye duyulan ihtiyaç Ba'lebekkî̀yi oldukça inciterek kendisine şu soruları sordurdu? "Yeni ortaya çıkan bir yazarı dilenme noktasına kadar reddetmek mümkün mü? Yeni ortaya çıkan bir erkek yazar olsaydım bu bana olmazdı ve kadın olduğumdan başka bir sebep olmaksızın vardığım dilenme noktasına gelmezdim." (Fettahoğlu, 2018: 423). Ba'lebekkî, kadınların bir eseri yayımlarken bile geleneksel kuralların getirdiği engellere takılmasına dair eleștirisini ifade etmiştir.

Şi'r yayınevi kitabı yayımlamak için Şaybûb ile iletişime geçse de basılması için gerekli olan meblağ mevcut değildi. Ba'lebekkî: "Bu yüzden kitabın basılması için gereken miktarı elde edene kadar çalıştım ve bu durum 1958'de gerçeklești" der (Fettahoğlu, 2018: 423). Yazar maddi durumu iyi olan babasından destek almamıştır. Geleneksel düşünceye karşı olmakla beraber Batı edebiyatı ve kültürünü önemli bir konuma yerleştiren ve bu anlamda tercüme faaliyetleri ile Arapçayı Batı dünyasını tanıtan Şi'r grubu, Ba'lebekkî̀nin önemli bir yazar ve şair grubu ile tanışmasına imkân sağladı. Bu anlamda Şi'r grubu yazarın hem özgürce ve cesurca yazmasını etkilemiş hem de yazmaya devam etmesine de vesile olmuştur.

Ene Ehyâ'nın yayımlanması ile Ba'lebekkî, bazı kesimlerce takdir edilse de genel olarak sert eleştirilerle karşılaşmıştır. Bu mesele yazarın kendisini Lübnan'ın en çok eleştiri alan yazarı olarak görmesine neden olmuştur. Yazar bu olay için: “Ene Ahyâ'yı yayımladım ve Leylâ Ba'lebekkî taşlandı. 1958'lerin Beyrut'u onu kabul etmedi; onun cesaretinden ve direnişinden korkuyorlardı. Dediler ki: Bu 20 yaşındaki kız, kadınların ne badirelerden geçtiğini nereden biliyor? Yazdığı şeyi yazmak için hayatında ne gibi deneyime sahip?" Dedi (Fettahoğlu, 2018: 423- 424).

Ba'lebekkî, 1961'de ikinci romanı olan el-İlâhetu'l-Memsûha (Korku Saçan İlahlar)'yı yayımladı. Bu eser Ene Ehyâ ile aynı konuları işlese de ilk romanın gölgesinde kalmıştır. 1964'te yayımlanan Sefînetu Hanân ile'l-Kamer (Ay'a Așk Gemisi) adlı hikâye koleksiyonu cinsel içerikli olduğu için halk nezdinde büyük bir infial yaratmıștır. Bu kitabından dolayı yazar yargılanmıştır. Mahkeme kararı bundan sonra yazarın yazacağı yayınların ancak incelendikten sonra basılabileceği şeklindedir. Bu durum kendisinin yazmayı bırakmasına neden olmuş ve sonrasında yazar gazeteciliğe devam etmiştir (Fettahoğlu, 2018: 424).

\section{Sonuç}

Sansür olgusu tarih boyunca her zaman insanlığın gündeminde olmuştur. Sansür kimi zaman edebiyatta, kimi zaman basında günümüzde ise internet gibi çeşitli mecralarda kendisini gösterir olmuştur. Edebiyat sahasında sansürün daha çok devletin ve toplumun gözettiği kaidelere aykırı durumlar yaşanması nedeniyle belirli bir mekanizma tarafından uygulandığı görülmektedir. Bu bağlamda devlete karşı olumsuz söylemler, toplum nezdinde ahlaki görülmeyen durumlar, cinsel ve müstehcen ifadeler gibi unsurlar edebi eserlerin sansüre uğramasının başlıca nedenleri arasında zikredilebilir. Her edebiyatta olduğu gibi Arap edebiyatında da sansüre maruz kalan eserler olmuştur. İlgili eserler kaleme alındığı ülke de basılamasa da diğer Arap ülkelerinde veya Avrupa ülkelerinde basılabildiğine tanıklık edilir. Geçen zamanla birlikte hem siyasi otoritenin hem de toplumsal şartların değişmesi ile yasaklanan eserlerin basılması gündeme taşınır olmuş ve bu durum bir şekilde aşılmıştır. Ancak tespit edilen bir durum vardır ki yasaklanan eserlerin her zaman daha dikkat çektiği ve daha fazla satış rakamlarına ulaştı̆̆ıdır. Ancak bu durum ilgili eserin beraberinde getirdiği olumsuz algıyı ne yazık ki ortadan kaldırmamaktadır. 


\section{KAYNAKÇA}

Bakır Dayı, Rumeysa, “Arap Edebiyatında Sansür ve Yakupyan Apartmanı Örneği”, Doğu Esintileri, 2021, Cilt, Sayı 15, s. 149-178.

Emekli, İlknur, "Abdurrahman Munif Hayatı, Edebi Kişiliği, Eserleri ve en- Nihâyât Adlı Romanının İncelenmesi", Atatürk Üniversitesi Sosyal Bilimler Enstitütüsü Yayımlanmamış Yüksek Lisans Tezi, Erzurum, 2006.

Fettahoğlu, Yeşim, “Lübnanlı Yazar Leylâ Ba'lebekkî’nin Yaşıyorum Adlı Romanı Örneğinde Kadının Özgürlük Arayışı”, Sosyal Bilimler Dergisi, Yıl: 5, Sayı: 32, Aralık 2018, s. 421-448.

Green, Jonathon, Karolides Nicholas J., Encyclopedia of Censorship, New York, 2005.

Ignacy Nasalski," Unwanted Literature. A Case of the Moroccan Writer Muhammad Šukrī ", Studia Litteraria Universitatis Iagellonicae Cracoviensis 11 (2016), z. 1, s. 17-26.

Karolides Nicholas J., Bald Margaret, Sova Dawn B., 120 Banned Books Censorship Histories of World Literature, Checkmark Books, New York, 2011.

Sakkut, Hamdi, The Arabic Novel (Bibliography and Critical Introduction 1865-1995), The American University in Cairo Press, New York, 2000.

Schwartz, Lowell H., Helmus Todd C, Kaye Dalia Dassa, Oweidat Nadia, "Barriers to the Distribution of Media Products in the Middle East", Barriers to the Broad Dissemination of Creative Works in the Arab World, RAND Corporation, 2009, California, p. 15-26.

Soyer, Senem, “Mısırlı Nevâl es-Sa'dâvî ile Duygu Asena'nın Eserleri ve Edebi Kişiliklerinin Karşılaştırılması", İstanbul Üniversitesi Sosyal Bilimler Enstitüsü Yayımlanmamış Doktora Tezi, İstanbul, 2016.

Yehia, Huda A., "Translation, Culture, And Censorship In Saudi Arabia (1988-2006) And Iraq (19792005)", (2007). Masters Theses 1911, Massachusetts, February 2014. 73.

(Çevrimiçi) http://www.sabitfikir.com/dosyalar/misirda-edebiyat-devrimi-nasil-etkiledi 25.11.2021

(Çevrimiçi) https://stepfeed.com/6-controversial-arab-authors-whose-books-got-a-lot-of-hate-8360 25.11 .2021

(Çevrimiçi) https://www.indyturk.com/node/55271/dünyadan-sesler/20yy'da-arap-dünyasını-sarsankitap 25.11.2021

(Çevrimiçi) https://www.vice.com/en/article/3b74kn/banned-books-week-and-middle-easternliterature-923 25.11.2021

(Çevrimiçi) http://www.sabitfikir.com/dosyalar/misirda-edebiyat-devrimi-nasil-etkiledi 25.11.2021 



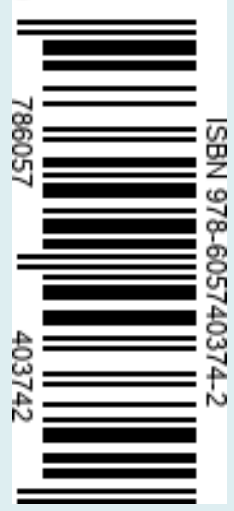

